SZEGEDI TUDOMÁNYEGYETEM

GAZDASÁGTUDOMÁNYI KAR

KÖZGAZDASÁGTANI DOKTORI ISKOLA

\title{
AZ EURÓPAI UNIÓ NEMZETKÖZI FEJLESZTÉSI POLITIKÁJÁNAK ÉRTÉKELÉSE: A KERESKEDELEMPOLITIKAI ESZKÖZÖK ADTA LEHETŐSÉGEK
}

Doktori értekezés

\section{Témavezető:}

DR. FARKAS BEÁTA intézetvezető egyetemi docens Szegedi Tudományegyetem Gazdaságtudományi Kar
Készítette:

UDVARI BEÁTA

Szegedi Tudományegyetem

Gazdaságtudományi Kar

Közgazdaságtani Doktori Iskola 


\section{KöSZÖNETNYILVÁNÍTÁS}

Jelen doktori értekezés több év kutatómunkájának eredménye, melynek során számos egyetemi és főiskolai oktatóm formálta gondolkodásmódomat, támogatott kutatásaim során. Először is szeretném megköszönni témavezetőm, Dr. Farkas Beáta munkáját, aki az elmúlt évek során figyelemmel kísérte szakmai előrehaladásom, segítette ötleteim megvalósítását, valamint rendszeres mühelybeszélgetéseket tartott. Ezúton is köszönöm a mühely tagjainak, egyben kollégáimnak, Dr. Pelle Anitának, Megyeri Eszternek, Somosi Saroltának, Ván Hajnalkának és Kiss Gábor Dávidnak az építő jellegü észrevételeit.

Köszönettel tartozom Dr. Rácz Margit, Dr. Kacsirek László és Dr. Mészáros Ádám főiskolai oktatóimnak és témavezetőimnek, akik az Európai Unió szövevényes rendszere mellett a világgazdasági, nemzetközi kérdések iránt is felkeltették érdeklődésemet. Mészáros Ádámnak külön köszönöm a dolgozatom korábbi verziójának rendkívül alapos átolvasását, a kapott építő kritikákat és javaslatokat. Ezúton is hálásan köszönöm egyetemi konzulensem és témavezetőm, Dr. Lukovics Miklós magas elvárásokkal párosuló alapos szakmai segítségét, melynek révén megalapozódtak ismereteim az EU fejlesztési politikájának témakörében. Köszönöm a mai napig használható tanácsait, azt, hogy ezen a pályán elindított, és hogy a későbbiekben is nyitott volt a beszélgetésekre. A módszertani kérdések megértését és alkalmazásának elsajátítását illetően szeretném megköszönni Gáspár Attila szerzőtársamnak a fáradhatatlan és szakmailag kimerítő e-mailjeit, a helyesen feltett kérdéseket, valamint végtelen türelmét és biztatását, illetve Dr. Kovács Péternek a folyamatos rendelkezésre állását, véleményét, kritikáit, továbbá Szakálné Kanó Izabellának az együttgondolkodást és az ökonometria-órákat. A látásmódom szélesítésében lelkes és alapos TDK-zó hallgatóimat is köszönet illeti: Lupsea Éva, Mezö Júlia és Czékus Ábel folyamatos gondolkodásra késztettek közös munkánk során. Mindemellett szeretném megköszönni elö-opponenseimnek, Dr. Kiss Juditnak és Dr. Szent-Iványi Balázsnak az alapos munkáját, észrevételeiket és javaslataikat átgondolva készült el jelen dolgozat. Továbbá köszönöm a munkahelyi vitán kapott, komoly megfontolásra alkalmas megjegyzéseket: Bajmócy Zoltánnak, Benet Ivánnak, Kiss Gábor Dávidnak, Lengyel Imrének, Pelle Anitának és Szegö Szilviának. Ezek mindegyike valamilyen formában bekerült e dolgozatba.

Mindemellett hálával tartozom Szüleimnek és Testvéreimnek, valamint Barátaimnak, akik végigkísértek ezen a folyamaton, mindvégig mellettem voltak, és eltürték azt, ha a munkám miatt kevesebb időm jutott rájuk. 


\section{TARTALOMJEGYZÉK}

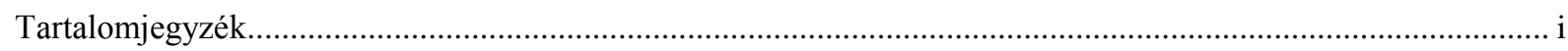

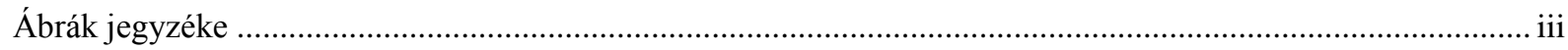

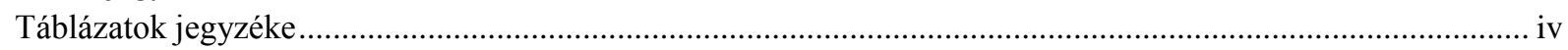

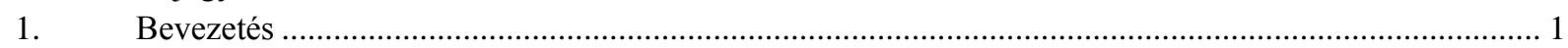

2. A fejlődő országok körének meghatározása és az elmaradottságukhoz vezető tényezők ........................9

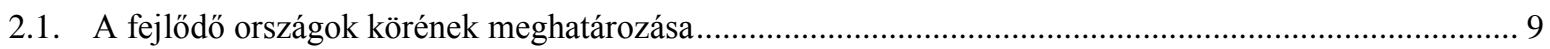

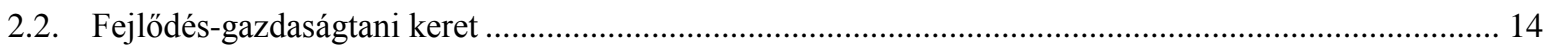

2.3. A fejlődő országok elmaradottságához vezető tényezők........................................................... 19

2.3.1. A nemzeti sajátosságok szerepe a fejlődő országok elmaradottságában ................................ 21

2.3.2. Az elmaradott országok fejlődését befolyásoló nemzetközi folyamatok ................................ 26

3. A nemzetközi segélyezés és a nemzetközi kereskedelem szerepe …............................................. 31

3.1. A nemzetközi fejlesztési együttmüködés főbb dilemmái ........................................................... 31

3.1.1. A fejlesztési együttmüködés lehetőségei és veszélyei .................................................... 32

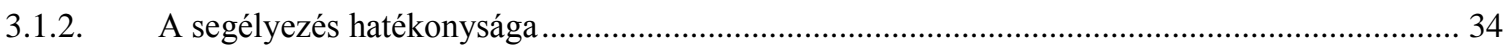

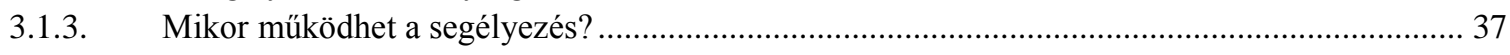

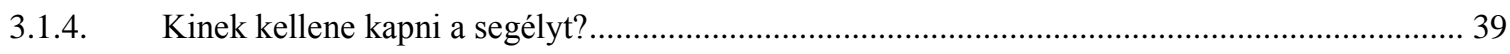

3.2. A nemzetközi kereskedelem szerepének megjelenése a gazdasági fejlödésben.................................41

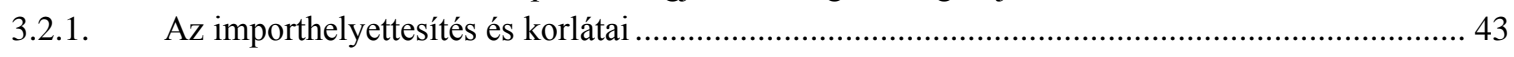

3.2.2. Az exportösztönzés mint gazdaságfejlesztési eszköz.................................................... 45

3.2.3. A nemzetközi kereskedelem gazdasági fejlődésben betöltött szerepe .................................. 49

3.2.4. Nemzetközi szervezetek véleménye a nemzetközi kereskedelem szerepéről .......................... 58

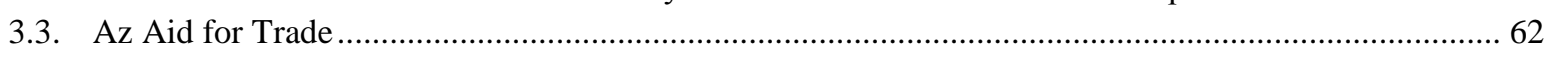

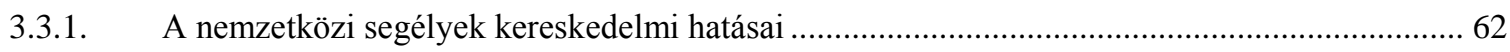

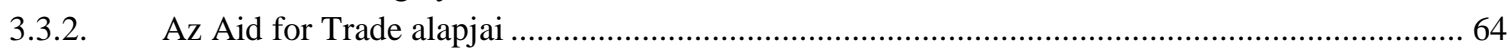

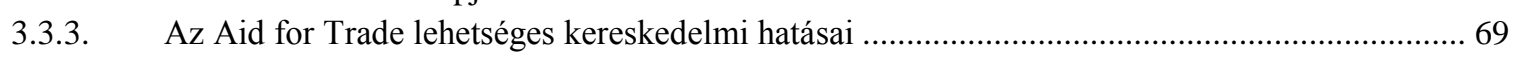

4. Az Európai Unió fejlesztési politikája az ezredfordulóig............................................................... 73

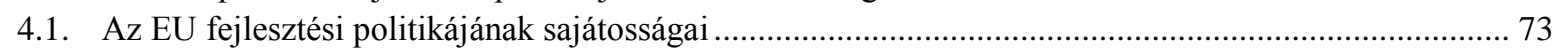

4.2. A Loméi Egyezmények hatásmechanizmusa és kereskedelmi eredményei ........................................ 79

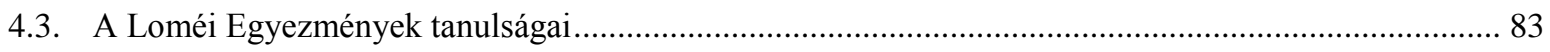

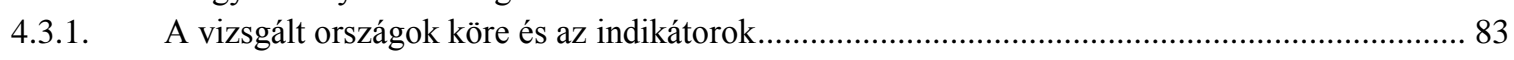

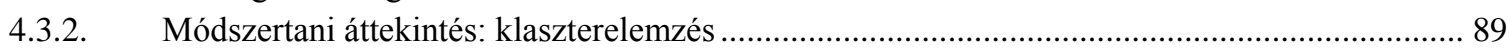

4.3.3. A klaszterelemzés gyengeségeinek kezelése ................................................................. 91

4.3.4. A Loméi Egyezményeket megelőző időszak eredményei...................................................... 94

4.3.5. A Lomé-rendszer előtti időszak elemzése: fökomponensek bevonása .................................... 98

4.3.6. A Lomé-rendszert követő időszak eredményei ..................................................................... 101

4.3.7. A két időszak eredményeinek összehasonlítása és következtetései ....................................... 106

4.4. A Loméi Egyezmények kudarcának lehetséges okai ................................................................. 113

4.4.1. A sikertelenség lehetséges külső okai ................................................................................ 114

4.4.2. A sikertelenség lehetséges belső okai .............................................................................. 117

5. Az Európai Unió fejlesztési politikája az ezredforduló óta ..........................................................119

5.1. Az EU álláspontja a nemzetközi kereskedelem szerepével kapcsolatban ...................................... 119

5.2. A Cotonou-i Partnerségi Egyezmény ................................................................................. 121

5.2.1. A Cotonou-i Egyezmény főbb jellemzői..................................................................... 121

5.2.2. A Gazdasági Partnerségi Megállapodások ...................................................................... 125

5.3. Az Aid for Trade az Európai Unióban ................................................................................... 129

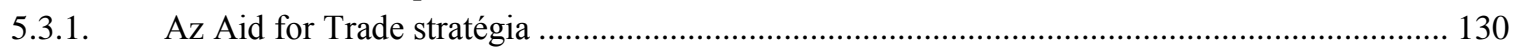

5.3.2. Az Aid for Trade illeszkedése az EU fejlesztési politikájába ............................................. 132

5.4. Az új tagállamok szerepe a közösségi fejlesztési politikában ..................................................... 134

5.5. Az Aid for Trade lehetséges hatásai az EU-val folytatott kereskedelemre ...................................... 137

5.5.1. A recipiensek és a donorok. A segélyek nagyságának mérése............................................... 139 


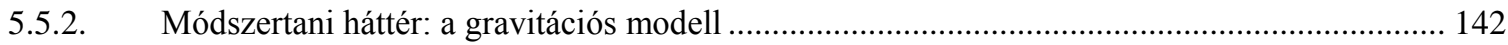

5.5.3. Elözetes elemzés: a vizsgált sokaság megismerése ......................................................... 150

5.5.4. A teljes Aid for Trade hatásai a kereskedelemre - eredmények ......................................... 152

5.5.5. Az egyes AfT-területek hatásai a kereskedelemre - eredmények ....................................... 155

5.5.6. Az ACP és nem-ACP csoportok eredményei............................................................. 157

5.5.7. A modell robusztusságának ellenőrzése ................................................................... 160

5.5.8. Az EU-s AfT empirikus vizsgálatának eredményei összességében ..................................... 163

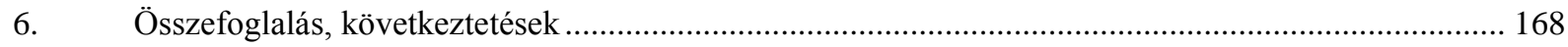

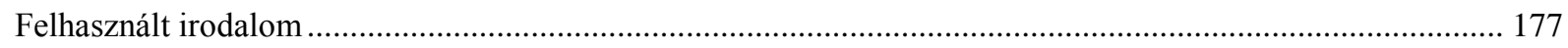

1. számú Melléklet: A fejlődő országok köre.................................................................................... 196

2. számú Melléklet: Az országok klasztertagsága a Loméi Egyezmények előtt - eredeti változók, faktorok .... 197

3. számú Melléklet: Az országok klasztertagsága a Loméi Egyezmények után .......................................... 199

4. számú Melléklet: A gravitációs modell alapjául szolgáló országok...................................................... 200

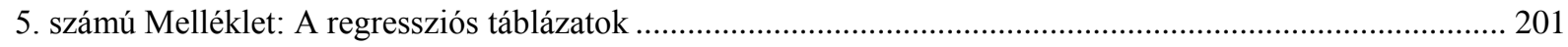

6. számú Melléklet: A regressziós táblázatok - kiugró értékek nélkül ....................................................... 211 


\section{ÁBRÁK JEGYZÉKE}

2.1. ábra A fejlődő országok különböző csoportjai ................................................................................... 13

3.1. ábra A GDP/fó és a segélyezés alakulása Fekete-Afrikában, 1970-2009............................................... 34

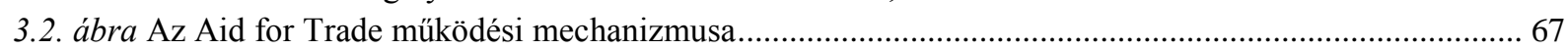

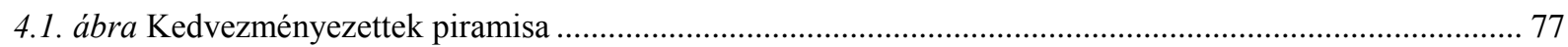

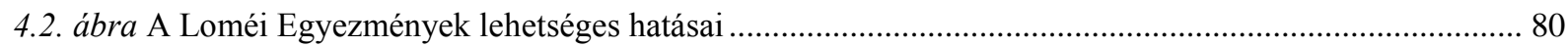

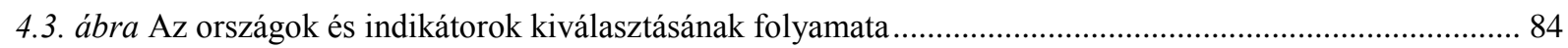

4.4. ábra A Loméi Egyezmények elméleti hatásmechanizmusa és a befolyásoló tényezők ............................... 88

4.5. ábra A két időszak klasztereinek relatív helyzete ............................................................................. 108

5.1. ábra A lehetséges ACP-EU megállapodások köre............................................................................ 124

5.2. ábra Az alacsony hatékonyság okai és az Aid for Trade .................................................................. 133

5.3. ábra A vizsgálatban szereplő országok jellemzői ................................................................................... 139

5.4. ábra Az Aid for Trade-hatások elemzésének áttekintése ......................................................................... 149

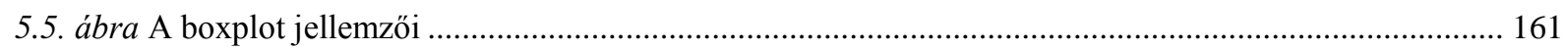




\section{TÁBLÁZATOK JEGYZÉKE}

2.1. táblázat Fejlődő országok száma az egy före jutó GNI alapján (darab).................................................... 10

2.2. táblázat A fejlődés-gazdaságtan elméletei néhány kiemelt szerző művében ............................................... 15

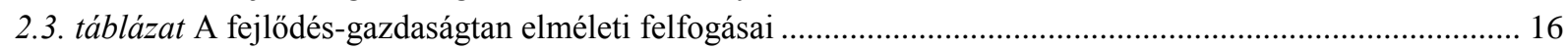

2.4. táblázat A fejlődő országok elmaradottságához vezető tényezők ................................................................ 20

3.1. táblázat A segélyek veszélyei, illetve lehetséges pozitív hatásai ............................................................. 33

3.2. táblázat Egyes térségek részesedése a világexportból, 1980-2009 (\%) …………..................................... 56

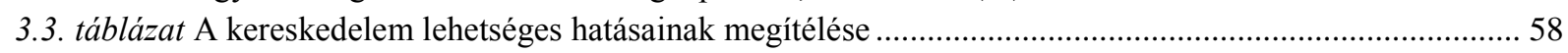

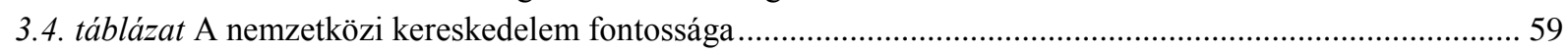

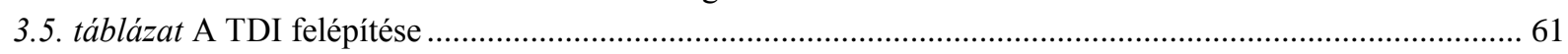

3.6. táblázat Az Aid for Trade létrejöttének erősségei, kritikái ........................................................................ 68

3.7. táblázat Az Aid for Trade megítélése a vonatkozó elemzésekben ............................................................... 70

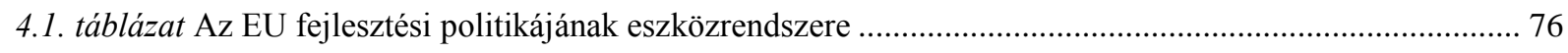

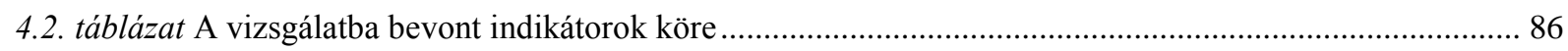

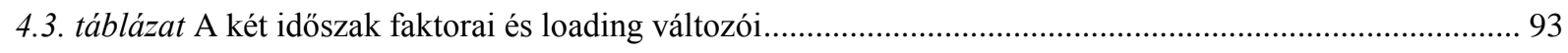

4.4. táblázat Klaszterek tagsága 6 klaszter esetén (országok száma, db) ........................................................... 95

4.5. táblázat A klasztertagság alakulása különböző számú klaszterek esetében (országok száma, db) ................ 95

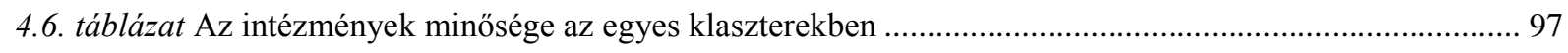

4.7. táblázat $\mathrm{A}$ régiók és a klaszterek kereszttáblája (országok száma, db) ...................................................... 97

4.8. táblázat Az 5 klaszter a faktorokkal az első időszakban (országok száma, db) ………………................... 99

4.9. táblázat $\mathrm{A}$ klaszterek földrajzi megoszlása az első időszakban (országok száma, db) ................................ 100

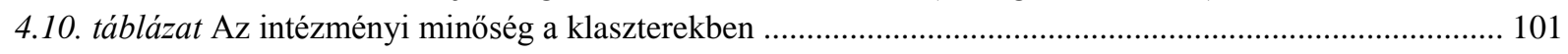

4.11. táblázat $\mathrm{A}$ lehetséges klaszterek tagjainak alakulása (országok száma, db) ……………………........... 101

4.12. táblázat A klaszterek tagsága Szingapúr kizárásával (országok száma, db) ………………………….... 102

4.13. táblázat Az 5 klaszter az Egyezmények után (országok száma, db) …………………………….......... 102

4.14. táblázat Az intézményi háttér minősége az egyezmények után ............................................................. 104

4.15. táblázat Kedvezményezetti csoport és egyezmények aláírása (országok száma, db) ................................ 105

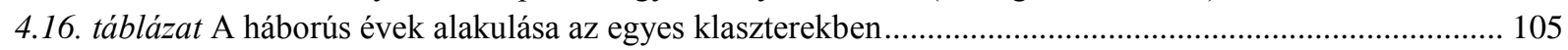

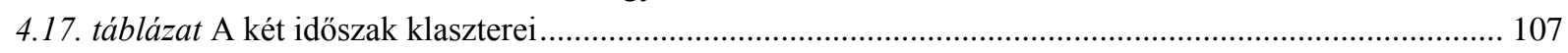

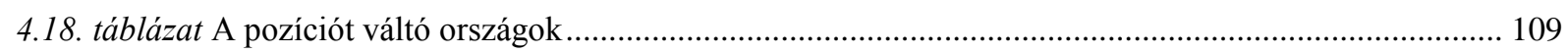

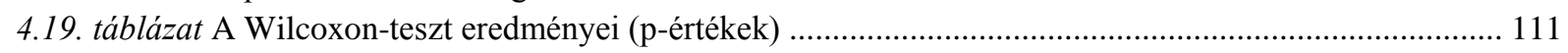

4.20. táblázat A Loméi Egyezmények sikertelenségének lehetséges okai...................................................... 114

5.1. táblázat A Loméi és a Cotonou-i Egyezmények közötti föbb különbségek................................................ 123

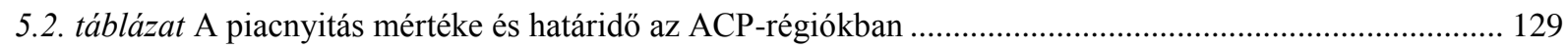

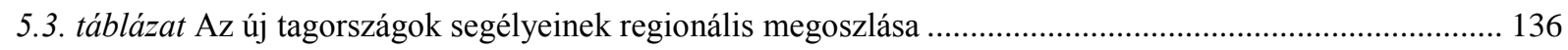

5.4. táblázat Egyes régiók részesedése az EU harmadik országokkal folytatott kereskedelméből, 1980-2005 (\%)

138

5.5. táblázat Az Aid for Trade adatai az OECD adatbázisában ................................................................... 141

5.6. táblázat Az ACP és a nem ACP-országok Aid for Trade támogatásai: átlagok és szórások (ezer USD) .... 150

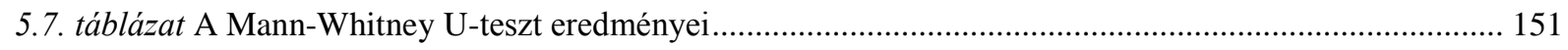

5.8. táblázat Korreláció a függő változó (teljes kereskedelem) és az egyes magyarázó változók között ............ 151

5.9. táblázat A regressziós modell koefficiensei (és p-értékei) - Teljes Aid for Trade ..................................... 153

5.10. táblázat A regressziós modell koefficiensei (és p-értékei) - Az Aid for Trade részterületei ...................... 155

5.11. táblázat Az ACP és nem ACP országok regressziós modelljének koefficiensei (és p-értékei) ................. 158

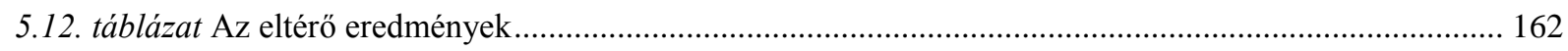


„A fejlödés alapvetö emberi jog. A fejlödés a béke legbiztosabb alapja."

(Boutros-Ghali 1995, 4. о.)

\section{BEVEZETÉS}

A 21. században számos, a nemzeti határokon átívelő és nemzetközi összefogást igénylő ún. globális probléma vár megoldásra (Simai 2008, UN 2011a), azonban ezek közül több a fejlődő országok gazdasági (és társadalmi, politikai, intézményi) elmaradottságához köthető. Ebből kifolyólag napjainkban rendkívül fontos és megoldásra váró kérdés a fejlődő országok elmaradott gazdasági helyzetének javítása, gazdasági (és társadalmi) fejlődés elérése. Egyrészt erkölcsileg elfogadhatatlan az, hogy a fejlődő országok népességének nagy részét érinti a - szélsőségesnek is nevezhető - szegénység (a napi 1-2 dollárnál kevesebből élők), a mindennapos éhezés, és jelentősek a társadalmi különbségek. Másrészt a nemzetközi közösséget is érintő problémáról van szó: a globalizáció, a felgyorsult liberalizáció, a nemzeti határok fokozatos eltünése, a migráció, az egyre fenyegetőbb nemzetközi terrorizmus, a járványveszély, a környezetszennyezés és a kimerülő erőforrások nem hatékony felhasználása miatt ma már - tág értelemben vett - biztonsági kérdés a fejlődő országok gazdasági lehetőségeinek, akadályainak kutatása. Ennek eredményeként a fejlesztés, a fejlesztési együttmüködés, illetve a segélyezés is hangsúlyossá vált a nemzetközi kapcsolatokban. Mindezt igazolják Kemal Dervis, az UNDP ${ }^{1}$ főtitkárának szavai is (UNDP 2007, 2. o.): „A globalizáció alapjaiban változtatta meg a világgazdaságot, létrehozva a gyöztesek és vesztesek csoportját. Az országon belüli és az országok közötti egyenlötlenségek csökkentése, valamint inkluzív globalizáció megteremtése jelenünk legfontosabb fejlesztési kihívása."

A fejlődő országok elmaradottsága és az ebből fakadó jelentős (világgazdasági) probléma gyökerei még a gyarmatosítás korára nyúlnak vissza, azonban - a mai formájában vett - problémává a múlt század közepén fejlődött ki. 1945 után nagymértékben átalakult a világgazdaság képe, ennek oka a második világháború után elindult újabb dekolonizációs folyamat (a 19. századi latin-amerikai függetlenedés után). Az újonnan függetlenné vált országok többségének szembesülniük kellett azzal, hogy nem tudnak lépést tartani a világban zajló folyamatokkal, nem képesek azokra megfelelő módon reagálni, és a nemzetközi fejlődési szakadék mélyül. Kialakult egy ugyanolyan alapproblémákkal rendelkező országokból álló, az elmúlt évtizedek során többféleképpen nevezett csoport: a Harmadik

\footnotetext{
${ }^{1}$ United Nations Development Programme - az ENSZ Fejlesztési Programja
} 
Világ, a Dél, a fejlődö országok csoportja, vagy Wallersteint terminológiájával élve félperifériának és perifériának is nevezhetők ezek az országok. ${ }^{2}$

Ezen országok elmaradottságának vizsgálata fontos közgazdasági kérdéssé vált: a fejlődés-gazdaságtan foglalkozik az elmaradott (fejlődő) országok gazdasági fejletlenségének okaival és felszámolási lehetőségeivel. Az elmúlt hat évtized során számos nézet született a fejlődő országok elmaradottságának okaira vonatkozóan. E tényezők között nem lehet éles különbséget tenni. Nurkse és Myrdal is elfogadja azt, hogy ezek az országok egy ún. ördögi körbe kerültek bele (Myrdal 1957), ahol egyes okok már egy másik ok okozatává váltak (,,a szegény országok szegények, mert szegények”). Ennek következtében - a függőségi iskola nézeteivel teljesen ellentétesen - a fejlődő országok egyedül nem tudnak úrrá lenni problémájukon, szükséges, hogy a nemzetközi közösség, a fejlett(ebb) országok segítséget nyújtsanak számukra. Mindez pedig napjainkban különösen indokolt, mivel globális hatása (is) van a fejletlenségük következményeinek. Ráadásul a 20. század közepén elkezdődött liberalizációs folyamat sem kedvezett számukra: az elmaradott országok gyenge alkupozícióval rendelkeztek, így a „fejük felett” döntöttek több kérdésben is. Ezt a jelenséget a neokolonializmus fogalmával illetik, hiszen a hatalom, amely a gyarmatai révén korábban jelentős gazdasági haszonhoz jutott, a dekolonizáció után más módon próbál e gazdasági előnyökhöz hozzájutni (Stoneman és Suckling 1987).

Az 1950-60-as évektől kezdődően egyre több nemzetközi szervezet jött létre, melyek a fejlődő országok hátrányos helyzetének felszámolását tüzték ki célul, bár fejlesztési törekvéseiket a különböző fejlődés-gazdaságtani elméletek jelentősen befolyásolták. A szervezetek mellett egyre bővül azon programok köre, melyek az elmaradottabb államok megsegítésére irányulnak. Ezen szervezetek és programok közül kiemelkedik az ENSZ számos szakosított szervezetével (például $\mathrm{WHO}^{3}, \mathrm{IMF}^{4}$ ) és programjaival (például UNDP, UNCTAD ${ }^{5}$ ), emellett az $\mathrm{OECD}^{6}$ is jelentős szerepet vállal. A növekvő források ellenére a nemzetközi közösség beavatkozása, a fejlesztési együttműködés hatékonysága megkérdőjelezhető: 60 év alatt egyedül csak a Világbank több mint 2,3 billió

\footnotetext{
${ }^{2}$ Wallerstein azonban nem a függetlenedésre vezeti vissza ezen országok kialakulását, hanem a kapitalizmus után kialakult egyenlőtlen fejlődést tekinti oknak (Wallerstein 2006, 2010).

${ }^{3}$ World Health Organization - Egészségügyi Világszervezet

${ }^{4}$ International Monetary Fund - Nemzetközi Valutaalap

${ }^{5}$ United Nations Conference on Trade and Development - az ENSZ Kereskedelmi és Fejlesztési Konferenciája

${ }^{6}$ Organization for Economic Cooperation and Development - Gazdasági Együttműködési és Fejlesztési Szervezet
} 
dollár $^{7}$ fejlesztési támogatást juttatott a fejlődő országokba, a szegénység azonban még mindig jelentős mértékü probléma ezekben az országokban (Weller és Yi-Chong 2009).

Napjainkban azonban nem kizárólag a pénzügyi támogatásokat tekintik fejlesztési eszköznek: a segélyek, kedvezményes hitelek, egyéb programokhoz kötött pénzügyi támogatások mellett egyre inkább terjed az az alapvetően (neo)klasszikus felfogás, hogy a nemzetközi kereskedelemben való részvétel hozzájárulhat a gazdasági fejlődéshez, valamint a szegénység csökkenéséhez (Dollar és Kraay 2003, Hallaert és Munro 2009), annak ellenére, hogy erre vonatkozóan nincs egyértelmü empirikus bizonyíték. E folyamat hangzatos jelszava a „Trade not aid”, azaz kereskedj, ne segélyezz (UNCTAD 2008a). A nemzetközi szervezetek és a nemzetközi közösség részéröl egyre több jel utal arra, hogy elfogadják ezt a tézist, mely arra enged következtetni, hogy a hagyományos finanszírozási források mellett a nemzetközi kereskedelemben való részvétel elősegítése is a fejlesztési eszközök között jelenik meg. Emellett még mindig releváns kérdés, hogy a fejlődő országoknak milyen mértékben kell megnyitniuk gazdaságukat a fejlődés érdekében (Hout 1996). Így jelen értekezés a nemzetközi kereskedelemben való részvétel és a gazdasági fejlődés közötti kapcsolat vizsgálatára helyezi a hangsúlyt, abból a szempontból, hogy a nemzetközi kereskedelem fejlesztési eszköz lehet-e.

A vizsgálandó téma relevanciáját és aktualitását több tényező is igazolja. Egyrészt a globalizáció a kereskedelmi liberalizációt segíti elő (és fordítva), ugyanakkor sürgeti is annak megvalósulását. Ettől a folyamattól nem függetlenül a Kereskedelmi Világszervezet (WTO) keretében zajló liberalizációs folyamat szintén a nemzetközi munkamegosztásban való részvételt „kényszeríti” rá az országokra. Továbbá a WTO-nak ma már 153 ország a tagja, így az egyre több területre kiterjedő liberalizáció már szinte megkerülhetetlen. ${ }^{8}$ Valamint az 1990-es évek eleje óta jelentős mértékű növekedés tapasztalható az országok közötti regionális megállapodások számában (már több mint 300 egyezmény létezik), melyek középpontjában a szerződő felek közötti kereskedelmi preferenciák biztosítása, illetve a szabad kereskedelem megvalósítása áll (WTO 2011). Emellett egyre több, nemzetközi szervezetek által kiadott hivatalos dokumentumban jelenik meg a nemzetközi kereskedelem mint fejlesztési eszköz koncepciója (lásd például UN 2000, UN 2003, UNCTAD 2005a). Ezek következtében talán, de a minél hatékonyabb részvétel elérése és fenntartása érdekében - és az „önmagában is müködik” felfogás helyett - a koncentráltabb („témaorientált”) segélyezés

\footnotetext{
${ }^{7}$ A világ 2009. évi GDP-jének közel 4 százaléka, Magyarország 2009. évi GDP-jének közel 18-szorosa.

${ }^{8}$ Hangsúlyozzuk, hogy a WTO és a kereskedelmi tárgyalásainak problémái nem képezik jelen dolgozat tárgyát, azokra csak a megértéshez szükséges mélységben térünk ki.
} 
is elkezdődött az Aid for Trade ${ }^{9}$ nemzetközi kezdeményezés keretein belül, így a Trade, not aid helyett ma már inkább az Aid for Trade felfogás került elötérbe (Huchet-Bourdon et al 2009). Viszont a kettő nem választható el élesen egymástól, hiszen mindkettő célja a nemzetközi munkamegosztásban való részvétel erősítése.

Korábban az exportösztönzés stratégiáját, a kereskedelem és a gazdasági növekedés közötti kapcsolatot már több szempontból vizsgálták, akárcsak a kereskedelmi preferenciák szerepét. Némileg kevesebb kutatás irányult a szerződéses formában nyújtott kereskedelmi kedvezmények lehetséges gazdaságfejlesztési hatásainak elemzésére, különösen olyan államok, tömörülések, integrációk esetében, amelyek már évtizedek óta elfogadják a nemzetközi kereskedelemben való részvételt fejlesztéspolitikai eszközként - mint például az Európai Unió. Ezek alapján a dolgozatban elsődlegesen az Európai Unió és annak fejlesztési politikájának értékelésével foglalkozunk, ahol is a hangsúly a kereskedelempolitikai eszközök eredményességének vizsgálatán van. Mivel az európai fejlesztési politika értékelése - főleg hazai szinten - háttérbe szorul, így még inkább megalapozott a téma kutatása és mélyebb elemzése. Emellett az Európai Unió teljes mértékig alkalmas a vizsgálatunk konkrét példán keresztül történő bemutatására, hiszen az EU már régóta biztosít kereskedelmi preferenciákat a fejlődő országoknak, azok közül számosnak viszonosság nélküli kedvezményeket garantált hosszú időn át. Ennek alapját az 1975-ben indult és 2000-ben lejárt Loméi Egyezmények adják, melyet az afrikai, karibi, csendes-óceáni (ACP) országokkal kötöttek az EU-tagországok. A négy Loméi Egyezmény szerződéses formában biztosított szabad piacra lépést az aláíró ACP-országok számára az európai piacokra, amely kiegészült még egyéb gazdasági és pénzügyi együttműködéssel. Összességében az európai fejlesztési politika részeként lehet a Loméi Egyezményekre és az általuk biztosított preferenciákra tekinteni. Választásunkat indokolja továbbá az is, hogy a régóta és állandó jelleggel, szerződéses formában biztosított kedvezmények lehetővé teszik a hosszú távú vizsgálatot. Továbbá, az európai uniós dokumentumokban az ezredforduló óta nyíltan megjelenik a nemzetközi kereskedelemben való részvétel javításának fejlesztéspolitikai szerepe, valamint saját Aid for Trade stratégiát fogadott el. Így az EU a fejlődő országok világgazdasági integrálását egyértelműen a fejlesztési politikájának eszközeként fogadja el a mai napig.

\footnotetext{
${ }^{9}$ Az Aid for Trade a 2000-es évek közepén elindított, a nemzetközi közösség által elfogadott program, mely a fejlődő országok kínálatoldali kapacitásának támogatása és fejlesztése révén a hatékonyabb és eredményesebb nemzetközi kereskedelemben való részvétel elősegítését tekinti céljának.
} 
Mindezek alapján jelen doktori értekezés célja annak vizsgálata, hogy az Európai Unió fejlesztési politikája a kereskedelempolitikai eszközök tekintetében milyen mértékben tekinthető eredményesnek: a nemzetközi kereskedelemben való részvétel és a gazdasági növekedés, fejlődés közötti kapcsolat meglétének feltételezése esetében mennyire eredményes az EU ezen tevékenysége. Az eredményességet a fejlődő országok szemszögéből vizsgáljuk, és azt elemezzük, hogy az EU-val a legszorosabb kapcsolatban álló államok hogyan teljesítettek és teljesítenek azon fejlődő országokhoz képest, amelyek az EU-tól kevesebb kereskedelmi preferenciában részesültek. Az európai fejlesztési politikai tevékenység minél átfogóbb értékelése érdekében a múlt és a jelen (jövő) vizsgálata egyaránt megtörténik. A múltbeli tevékenység elemzése a Loméi Egyezmények és azok eredményessége alapján valósul meg, míg a jelen (esetlegesen a jövő) lehetséges irányvonalait az Aid for Trade elemzése során kapott eredmények biztosítják, hiszen ezen elemzés adhat magyarázatot arra, hogy az Aid for Trade mennyiben jelenthet további fejlődési lehetőséget a Loméi Egyezményekhez képest. Ugyan a Cotonou-i Egyezmény a jelenleg érvényben lévő megállapodás az ACP-országok és az EU-tagországok között, ennek vizsgálatára közvetlenül nem térünk ki. Ennek oka, hogy az egyezmény keretében megkötendő partnerségi megállapodások tárgyalása még nem zárult le.

Ebből következően jelen dolgozat két fontos kérdést is érint a gazdasági fejlődés vonatkozásában: egyrészt a nemzetközi fejlesztési együttműködés, másrészt a nemzetközi kereskedelem e folyamatban betöltött szerepét. E kérdésekhez kötődik két, eltérő módszeren alapuló empirikus vizsgálat, melyek során az alábbi, az elméleti áttekintés során leszürt konzekvenciák alapján megfogalmazott hipotéziseket vizsgáljuk:

- 1. hipotézis: Az ACP-országoknak a Loméi Egyezmények beavatkozási területeihez köthető gazdasági teljesítménye a Lomé-rendszert követően kedvezőbb az egyezményeket alá nem író fejlődő országok gazdasági teljesítményéhez képest.

- 2. hipotézis: A Loméi Egyezmények beavatkozási területei alapján meghatározott gazdasági indikátorok figyelembe vételével a heterogén ACP-országok több, egymástól jól elkülöníthető, homogén csoportra bonthatóak.

- 3. hipotézis: Az Aid for Trade céljai és beavatkozási területei alapján illeszkedik az Európai Unió fejlesztési politikájába, és az egyéb fejlesztéspolitikai eszközök hatékonyságának javításához hozzájárul. 
- 4. hipotézis: Az ACP-országok több Aid for Trade-támogatásban részesülnek, mint a csoporton kívüli fejlődő országok, és a támogatások kereskedelembővítő hatása az ACP-országok körében nagyobb, mint az ACP-csoporton kívüli országokban.

- 5. hipotézis: Az EU fejlesztési céllal használt kereskedelempolitikai eszközei hozzájárulnak az ACP-országok gazdasági fejlődéséhez.

A dolgozat kifejtése a téma megközelítése alapján két nagyobb részre tagolható, melyek két-két fejezetet tartalmaznak. Az első nagyobb rész (2. és 3. fejezet) elméleti síkon közelíti meg a feldolgozott és kutatott témát, míg a második blokk (4. és 5. fejezet) mindezt az elméleti fejtegetés tanulságait felhasználva - konkrét példán, az Európai Unió gyakorlatán keresztül vizsgálja. A kifejtés az alábbi logika szerint történik. A második fejezetben a dolgozatban használt fogalmakat és az azok megértéséhez szükséges elméleti koncepciókat mutatjuk be. Bár a fejlődő országok mint fogalom széles körben használt, ennek pontos meghatározása komoly nehézségekbe ütközik. Mivel az értekezés központi elemét a fejlődő országok gazdaságának (empirikus) vizsgálata képezi, így elengedhetetlen ezen országok körének egyértelmű meghatározása, valamint az elmaradottságuk mögött meghúzódó tényezők ismertetése a fejlődés-gazdaságtani alapok bemutatásával.

A dolgozat harmadik fejezetében részletezzük a nemzetközi segélyezés és a nemzetközi kereskedelem gazdasági fejlődésben betöltött szerepét. Ugyan a fejlesztési segélyezés az értekezés konkrét témájától kissé távolabb visz, azonban a dolgozat későbbi részében bemutatásra kerülő Aid for Trade miatt fontos megismerni a segélyezés gyengeségeit és veszélyeit. Így kitérünk a nemzetközi fejlesztési együttmüködés legfőbb dilemmáira, alacsony hatékonyságának (legnyilvánvalóbb) okaira, valamint elemezzük, hogy milyen körülmények között lehet hatékony. Ezek után a nemzetközi kereskedelem és annak fejlesztésieszköz-szerepét mutatjuk be. A fejezet első részében az exportösztönzés és importhelyettesítés stratégiáját részletezzük, hiszen mindkettő célja a gazdasági fejlődés elindítása a nemzetközi kereskedelemben való részvétel ösztönzése, valamint az importhelyettesítés esetén annak korlátozása révén. Majd áttekintjük a nemzetközi kereskedelem és a gazdasági növekedés, illetve gazdasági fejlödés közötti kapcsolatot elemző nemzetközi szakirodalmat. Ezzel célunk, hogy megállapítsuk: milyen körülmények között játszhat kiemelkedő szerepet a nemzetközi kereskedelemben való részvétel, és így az empirikus vizsgálatunk helyes alapokra épüljön. A fejezet végén konkrét példákon keresztül bemutatjuk, hogy a nemzetközi szervezetek hogyan vélekednek a nemzetközi kereskedelem fejlődésben betöltött szerepéről. A fejezet utolsó részében pedig a 2005-ben útjára indított Aid 
for Trade kezdeményezést ismertetjük: tartalma mellett a nemzetközi megítélését is részletezzük.

E két, alapvetően elméleti megközelítésű fejezet után a kutatás során leszürt tanulságokat konkrét példán keresztül elemezzük. A gyakorlati megközelítéshez az Európai Unió fejlesztési politikájára esett a választásunk, mivel az EU már évtizedek óta biztosít kereskedelmi kedvezményeket a fejlődő országok számára, és nyíltan elismeri, hogy a fejlesztési politikája részének tekinti a nemzetközi kereskedelemben való részvétel elősegítését, fejlesztését. Az Európai Unió tevékenységét két részre bontjuk: jelen értekezés negyedik fejezete az Európai Unió fejlesztési politikáját az ezredfordulóig értékeli. Az EU-s fejlesztési politika sajátosságain és eszközein, illetve a Loméi Egyezmények hatásmechanizmusán és eredményein túl a dolgozat fontos empirikus vizsgálata is ebben a fejezetben jelenik meg. A Loméi Egyezmények lehetséges gazdasági hatásait többváltozós statisztikai módszerekkel elemezzük: klaszterelemzéssel vizsgáljuk meg a mintába került 79 fejlődő ország relatív helyzetét és annak változását a Loméi Egyezményeket megelőző és követő időszakok között. A fejezet végén kitérünk a vizsgálat eredményei mögött meghúzódó tényezőkre, melyek az EU-s fejlesztési politika gyengeségei lehetnek, és további fejlődést rejtenek magukban.

A dolgozat záró, ötödik fejezete az EU-s fejlesztési politika ezredforduló óta kialakult jellemzőit mutatja be. Kitérünk a legújabb egyezményekre (Cotonou-i Partnerségi Egyezmény, Gazdasági Partnerségi Megállapodások), valamint részletezzük, hogy az Aid for Trade milyen szerepet tölt be az Európai Unió fejlesztési politikájában, és mennyiben járulhat hozzá hatékonyságának javításához. Az elméleti fejtegetések mellett empirikus vizsgálattal teszteljük az Aid for Trade kereskedelemgeneráló hatását. Gravitációs modellel ${ }^{10}$ vizsgáljuk meg azt, hogy az Aid for Trade és annak részterületeire érkező támogatások mennyiben járulnak hozzá az EU és a fejlődő országok, illetve az EU és az ACP- és nem ACP-országok közötti kereskedelem bővüléséhez. Mindez azért fontos, mert az Aid for Trade kezdeményezés és támogatásai a kereskedelem mögött meghúzódó infrastrukturális és intézményi fejlesztésekre fókuszálnak. Az Aid for Trade így nem kötött segélyként működik (elvileg), hanem a kereskedelemmel összefüggő, tágan értelmezett intézményrendszer fejlesztésére koncentrál. Mivel az Aid for Trade a Gazdasági Partnerségi Megállapodások végrehajtásához jelent segítségét, ezek pedig az EU-s fejlesztési politika eszközei, így

\footnotetext{
${ }^{10}$ A gravitációs modell lehetővé teszi egy ország potenciális külkereskedelmének megállapítását - figyelembe véve olyan tényezöket, mint például kereskedelempolitikai eszközök, közös nyelv, gyarmati múlt, közös pénz, piac nagysága, szállítás költsége (Anderson 2001, Gács 2007).
} 
lényegében a közösségi fejlesztési politika lehetőségeit is felmérhetjük. A végső konklúziók megfogalmazása során térünk vissza a felvetett hipotézisek helyességére is, megfogalmazva azok helytállóságát, illetve elvetését. Továbbá a kutatás folytatásának irányait határozzuk meg.

A kutatás és ezzel a dolgozat újszerüségét az Európai Unió fejlesztési politikájának többváltozós statisztikai elemzésen alapuló - értékelése adja, ahol is a hangsúly a kereskedelempolitikai eszközök hatásainak vizsgálatán van. Ennek több oka van. Egyrészt az EU fejlesztési politikájának elemzése hazai szinten nem tartozik a kedvelt kutatási témák közé, statisztikai vizsgálata pedig - nemzetközi szinten is - még csekélyebb. Másrészt a Loméi Egyezmények lehetséges hatásainak vizsgálata a legtöbb esetben csak a kereskedelmi oldal elemzésén keresztül történt (többnyire leíró statisztika alkalmazásával), a tágabb gazdasági hatások elemzése elmaradt. Harmadrészt sem a hazai, sem pedig a nemzetközi szakirodalomban nem foglalkoznak azzal, hogy az Aid for Trade mennyiben illeszkedik az Európai Unió fejlesztési politikájába, milyen hatásai lehetnek a partnerek közötti a kereskedelem alakulására, valamint a kedvezményezett csoportok átalakulására. Holott, az Aid for Trade a Gazdasági Partnerségi Megállapodások hatékonyságát hivatott emelni. Következésképpen, sokkal átfogóbb képet kapunk az Európai Unió fejlesztési együttműködéséről és annak eredményességéről. Mindennek megismerése pedig hazánk EUtagsága miatt és fejlesztéspolitikai kötelezettségvállalásai miatt is kiemelten fontos, hiszen Magyarország is hozzájárul - többek között - az Európai Fejlesztési Alap (EDF) forrásaihoz: hazánkból, a 10. EDF javára összesen 124,8 millió euró támogatás származik a 2008-2013 közötti időszakban. 


\section{A FEJLŐDŐ ORSZÁGOK KÖRÉNEK MEGHATÁROZÁSA ÉS AZ ELMARADOTTSÁGUKHOZ VEZETŐ TÉNYEZŐK}

A dolgozat ezen fejezetében a téma feldolgozása során alkalmazott fogalmakat és elméleti alapokat tekintjük át. Mivel a dolgozatban központi szerepet játszanak a fejlődő országok, és empirikus vizsgálat alapját jelentik, így ezek pontos meghatározása és a dolgozatban használt fogalom tisztázása kiemelten fontos. Ezek után bemutatjuk az elmaradottságukhoz vezető tényezőket. Mindez megfelelő alapot jelent arra vonatkozóan, hogy megismerjük a nemzetközi kereskedelem szerepét e folyamatokban.

\subsection{A FEJLŐDŐ ORSZÁGOK KÖRÉNEK MEGHATÁROZÁSA}

A fejlődő országok körének pontos meghatározása az egyértelmü „terminológiai probléma" (Kiss 2007a, 40. o.) miatt indokolt. Ezt igazolják azok a tanulmányok is, melyek eltérő számú fejlődő országot vonnak be vizsgálataikba, és néhol már-már kérdéses, hogy van-e egyáltalán annyi fejlődő ország. ${ }^{11}$ Annak érdekében, hogy a disszertációban az ilyen problémákat elkerüljük, rögzítjük azt, hogy mely definíció alapján járunk el a fejlődő országok kiválasztása során. Ehhez viszont néhány - elsősorban a nemzetközi szervezetek által használt - fogalmat át kell tekinteni, hogy pontosabban lássuk, miért az adott meghatározást használjuk.

A fejlettségben mutatkozó különbségek mérése a nemzetközi segélyezés, valamint a kereskedelmi kedvezmények biztosítása miatt kiemelten fontos tényező (Szentes 2011), így napjainkban igyekeznek egzakt módon definiálni a fejlődő országok körét. A fejlődő országok heterogenitása miatt ennek következménye viszont a definíciók sokfélesége és néhol túlzott általánosítása. Érdekes az is, hogy bár egyre több nemzetközi szervezet foglalkozik a fejlődő országok megsegítésével, fogalmi meghatározásuk mégis hiányos, valamint sokszor eltérō módon fogalmaznak. A következőkben kiemelünk néhányat ennek szemléltetésére. Például az ENSZ szerint fejlődő országnak minősülnek azok az államok, ahol „,az életszínvonal alacsonyabb, mint a fejlett országokban és az átmeneti gazdaságokban. Sokuk súlyos szegénységgel küzd. A fejlödő országok általában inkább a tudományos és technológiai innovációk importörei, mint fejlesztői” (UN 2011b). Ugyan a technológia-importőrök relatíve könnyen meghatározhatók, viszont a definícióban lévő, további meghatározást igénylő fogalmak (életszínvonal, fejlett ország) miatt (is) további kiegészítést találhatunk: mindazon

11 Például Cipollina és Salvatici (2010) vizsgálatukba 161 fejlődő országot vontak be, ami már-már hihetetlen számnak tünik. 
ország fejlődő ország, amely nem tartozik a magas jövedelmű, valamint az átmeneti országok közé.

A jövedelem, nevezetesen az egy före jutó bruttó nemzeti jövedelem (GNI) szerinti kategorizálás pedig egyre elterjedtebb, bár a jövedelmi szint vizsgálata nem lehet elégséges feltétele a fejlődő országok körének meghatározásához. Ennek oka, hogy egyes magas jövedelmű országok magas jövedelme kizárólag egy-két nagyon fejlett szektornak, nyersanyag-exportnak (elsősorban olaj) köszönhető, ennek ellenére a lakosság képzettsége, egészségügyi színvonala alacsony maradt (Todaro és Smith 2009), valamint az egyes fejlettségi kategóriák közötti határvonal megállapítása önkényes módon történik (Szentes 1976). Ez a gondolatmenet egyértelmủen megtalálható a Világbank meghatározásában, amit pedig az OECD, valamint az Európai Unió is elsődlegesnek tekint saját definíciója megalkotásakor. A Világbank (2011a) szerint a fejlődő országok az alacsony- valamint a közepes jövedelemmel rendelkező országok az egy főre jutó GNI alapján (2.1. táblázat), valamint öt magas jövedelmű ország (Hongkong, Izrael, Kuvait, Szingapúr, az Egyesült Arab Emírségek). Ez utóbbi kitétel alapján egyértelmü, hogy a jövedelmi szint vizsgálata nem lehet elegendő a fejlődő országok meghatározásához.

2.1. táblázat Fejlődő országok száma az egy főre jutó GNI alapján (darab)

\begin{tabular}{|c|c|c|c|c|}
\hline & $\begin{array}{c}\text { Alacsony } \\
\text { jövedelmü } \\
(<1005 \$)\end{array}$ & $\begin{array}{c}\text { Alsó közepes } \\
\text { jövedelmü } \\
(1006 \$-3975 \$)\end{array}$ & $\begin{array}{c}\text { Felső közepes } \\
\text { jövedelmü } \\
(3976 \$-12.275 \$) \\
\end{array}$ & Összesen \\
\hline $\begin{array}{l}\text { Kelet-Ázsia és } \\
\text { csendes-óceáni } \\
\text { térség }\end{array}$ & 5 & 15 & 4 & 24 \\
\hline $\begin{array}{l}\text { Európa és Közép- } \\
\text { Ázsia }\end{array}$ & 0 & 0 & 1 & 1 \\
\hline $\begin{array}{l}\text { Latin-Amerika és } \\
\text { a karibi térség }\end{array}$ & 1 & 9 & 20 & 30 \\
\hline $\begin{array}{l}\text { Közel-Kelet és } \\
\text { Észak-Afrika }\end{array}$ & 0 & 9 & 4 & 13 \\
\hline Dél-Azsia & 3 & 5 & 0 & 8 \\
\hline Fekete-Afrika & 29 & 11 & 7 & 47 \\
\hline Összesen & 38 & 49 & 36 & 123 \\
\hline
\end{tabular}

A Világbank definíciója szerint jelenleg 144 országot tekinthetünk fejlődőnek, melyek földrajzi megoszlása elég változatos. Bár a Világbank nem különíti el az átmeneti (tranzíciós) gazdaságokat, ezeket az ENSZ (UN 2011b) megfogalmazása szerint nem tekinthetjük fejlődő 
országnak, és a későbbi elemzésünkben is e szerint járunk el. ${ }^{12}$ Az átmeneti országok kivételével összesen 123 fejlődő országról beszélhetünk, melyek alacsony, illetve közepes jövedelemmel rendelkeznek. Hozzájuk kell még sorolni a korábban említett öt, a magas jövedelmüek közé tartozó országot, melynek eredményeként 128 fejlődő országot tartunk számon.

Mivel a dolgozatban az Európai Unió fejlesztési politikáját vizsgáljuk meg részletesebben, az EU fogalmi meghatározása sem maradhat ki. Bár az EU széles kapcsolati rendszerrel rendelkezik a fejlődő országokkal, nem határozott meg saját definíciót, hanem az OECD által elfogadott listát fogadja el. ${ }^{13} \mathrm{Az}$ OECD viszont a Világbank kategóriáit veszi figyelembe, és azokat az alacsony és közepes jövedelmű országokat tekinti fejlődő országnak, melyek jogosultak a hivatalos fejlesztési támogatásra, viszont nem tartoznak ide a G8, valamint az EU alacsony és közepes jövedelmű tagállamai, illetve azok az országok sem, melyek EU-csatlakozásának dátuma már ismert (OECD 2011a). Ezt a listát háromévente felülvizsgálják, a legutolsóra 2011 októberében került sor, mely 2012 januárjától hatályos a 2011-2013 közötti segélyfolyósításokra vonatkozó jelentéseket illetően (OECD 2011b). Mindezzel pedig elfogadhatjuk, hogy bár nem túl szerencsés az egy fôre jutó nemzeti jövedelem alapján az országok kategorizálása (hiszen e szerint például Kína is fejlődő országnak minősü1 ${ }^{14}$ ), mégis megfoghatóbb, mint bármely más definíció.

A dolgozat későbbi empirikus elemzése szempontjából fontos, hogy a fejlődő országok tág, mára heterogénné vált csoportján belül több, relatíve homogén csoport különíthető el. Ennek alapján lehet beszélni a tengerparttal nem rendelkező, szárazfölddel körülzárt országokról (land-locked developing countries, LLDC), a kis szigetekről (small island developing states, SIDS), valamint a legkevésbé fejlett országokról. Ezek közül részletesen a - dolgozat szempontjából fontos - legkevésbé fejlett országok jellemzőit ismertetjük. ${ }^{15}$ A legkevésbé fejlett országok (least developed countries, LDC) a fejlődő

\footnotetext{
${ }^{12}$. Átmeneti országok azon országok, melyek a tervgazdaságról a piacgazdaságra térnek át (UN 2011b), ezen országok közé tartoznak a Független Államok Közösségének országai, a kelet-közép-európai országok és a balti államok (UN 2011c). Az átmeneti országok pontos meghatározásához az ENSZ (UN 2011c) adatait vettük figyelembe

${ }^{13}$ Mivel hivatalos forrás nem érhető el erre a kérdésre vonatkozóan, kizárólag az Európai Bizottság Development \& Relations with ACP States igazgatóságának, Forward Looking Studies and Policy Coherence osztályának korábbi vezetőjével, Francoise Moreau-val váltott e-mailre támaszkodhatunk ezen állitás megfogalmazása során.

${ }^{14}$ Kína helyzete sajátos, hiszen a világ második legnagyobb gazdaságáról van szó, ugyanakkor számos olyan jegyet visel magán, ami miatt inkább fejlődő országnak minősül. Pagliari et al (2011) a centrum-periféria elemzése során Kínát a félperiféria országai közé sorolja, így ezzel a kiegészítéssel Kínát a dolgozatban fejlődő országnak tekintjük, de nem tévesztjük szem elöl sajátos helyzetét és az ebből fakadó torzító hatásokat.

${ }^{15}$ A többi említett országcsoport jellemzőit lásd részletesen UN-OHRLLS (2011a, 2011c, 2011d).
} 
országok legrosszabb helyzetben lévő és legszegényebb országai, ami miatt már-már negyedik világként $^{16}$ is emlegetik őket (Farkas 2005). A legkevésbé fejlett országok általánosan az alacsony nemzeti jövedelemmel rendelkező országok, viszont az LDC-státusz megítéléséhez az ENSZ bővebb kritériumrendszert állapít meg, amit háromévente felülvizsgálnak (UNOHRLLS 2011a). 2009 óta az ENSZ az alábbi kritériumok alapján állapítja meg a legkevésbé fejlett országok körét (UN-OHRLLS 2011a):

- alacsony jövedelem, amelyet az elmúlt három év átlagos egy főre jutó GNI alapján határoznak meg (905\$ alatt egyértelmüen be-, 1086\$ fölött kikerülnek az országok);

- humán tőke állapota, melyet egy komplex mutató, a HAI ${ }^{17}$ (Human Assets Index) segítségével mérnek;

- a gazdasági sebezhetőség foka, melyet a gazdasági sebezhetőség komplex indexével18 (Economic Vulnerability Index, EVI) számszerüsítenek.

Ezen indikátorok és kritériumok alapján az ENSZ legfrissebb listája 49 legkevésbé fejlett államot tart nyilván. A regionális megoszlásukat tekintve 33 ország Afrikában, 15 állam az ázsiai és a csendes-óceáni térségben, míg egy ország Latin-Amerikában található (UN-OHRLLS 2011b).

Mindezek mellett egyéb csoportok is megtalálhatóak: az adósság szintje alapján gyengén, közepesen, illetve súlyosan eladósodott gazdaságokról beszélhetünk (Világbank 2011a), míg a kiemelkedő teljesítmény alapján feltörekvő gazdaságokat (újonnan iparosodott országokat) is megkülönböztetnek, de külön csoportot alkotnak az olajexportőr-országok is a fejlődő országokon belül (Szentes 2011, UN 2011b). Továbbá - ahogyan az EU esetében látni fogjuk - a kapcsolati rendszer alapján is kialakulhatnak többé-kevésbé homogén csoportok, mint például az afrikai, karibi, csendes-óceáni (ACP) országok csoportja. ${ }^{19}$ Ez a sokféleség ugyan néhol zavaró, azonban nem tekinthető problémának ennyi csoport létezése, hiszen e klasszifikációk célja a minél homogénebb csoport kialakítása, ezzel pedig a fejlesztési lehetőségeik minél egységesebb kezelése.

\footnotetext{
${ }^{16}$ Szentes (2011) emellett ötödik világot is emleget, aminek a megjelenése lényegében a fejlődő országok differenciálódásának köszönhető.

${ }^{17}$ A HAI az alábbi tényezőket veszi számításba (UN-OHRLLS 2011a): tápláltság (az alultápláltak aránya a népességen belül), egészség (gyermekhalandóság aránya), oktatás (középfokú oktatásban résztvevők aránya), felnőttek írni-olvasni tudása.

${ }_{18} \mathrm{Az}$ index az alábbi tényezőket veszi számításba (UN-OHRLLS 2011a): népesség nagysága, távoli elhelyezkedés és elszigeteltség (remoteness), áruexport koncentráltsága, mezögazdaság aránya a GDP-ben, természeti katasztrófák következtében otthontalanná válás, mezőgazdasági termelés instabilitása, az áruk és szolgáltatások exportjának instabilitása. Az indikátorról és a hátteréről Guillaumont (2008) ad részletes áttekintést.

${ }^{19} \mathrm{Az}$ ACP-országok jellemzöit a 4.1. fejezetben részletezzük.
} 
A dolgozatban bemutatott csoportok összefoglalása alapján az átfedések jól kirajzolódnak (2.1. ábra). A fejlődő országok többféle típusú országok összességéből áll: közöttük vannak jobb (felső közepes jövedelmü országok), illetve rosszabb (alacsony jövedelmű országok) helyzetben lévő államok. A legkevésbé fejlett országok egyértelműen az alacsony jövedelmi szintü országokból kerülnek ki, illetve a szárazfölddel elzárt, valamint a kis szigetországok kétség nélkül legkevésbé fejlett országoknak minősülnek. Az egyéb csoportba tartozó országok többnyire azonban a magasabb jövedelmi szintű országok. A fejlődő országok heterogenitása pedig különösen érdekessé teszi az ezen országok gazdasági helyzetének kutatását, hiszen egyértelmủen relevánssá teszi azt a kérdést, hogy egyes országok miért sikeresebbek a másoknál, és hogy a különféle fejlesztési törekvések mennyiben lehetnek sikeresek, egyáltalán sikeresek lehetnek-e minden fejlődő országban, vagy csak azok egy csoportjában.

\section{1. ábra A fejlödő országok különböző csoportjai}

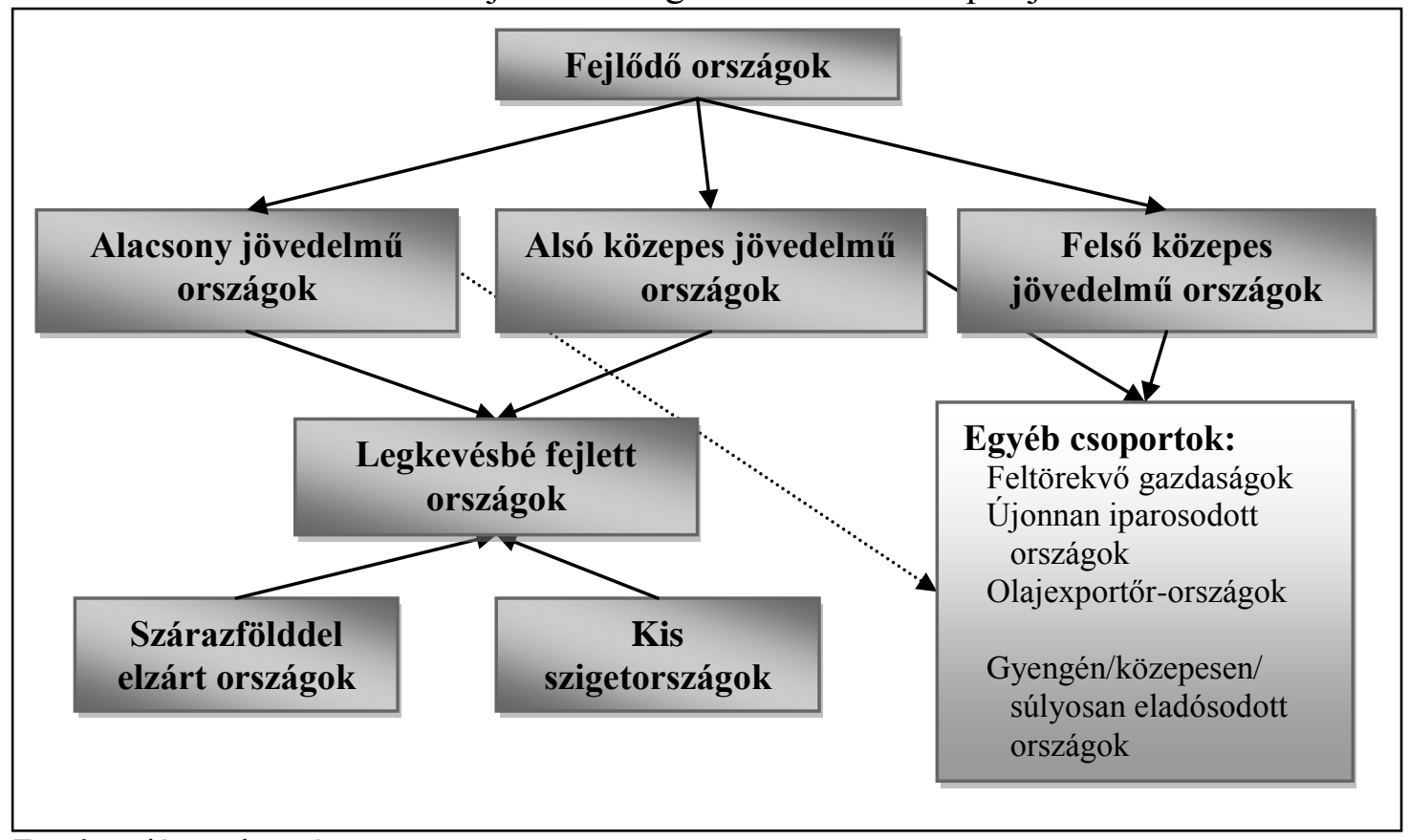

Forrás: saját szerkesztés

Mindezeket összegezve, a dolgozatban végig a fejlődő országok alatt az alacsony és közepes jövedelmü országokat értjük a Világbank csoportosítása alapján, valamint az ENSZ ajánlásai és az OECD listája alapján az átmeneti országokat és a magas jövedelmü országokat nem vesszük bele a fejlődő országok csoportjába. Ennek alapján az 12.275 USDnál alacsonyabb GNI/fővel rendelkező 123 országot tekintjük fejlődőnek ${ }^{20}$ (lásd korábban a 2.1. táblázatot), és ezeket az országokat tekintjük kiindulási pontnak a későbbi empirikus

\footnotetext{
${ }^{20}$ A fejlődő országok listáját lásd az 1. számú Mellékletben.
} 
vizsgálatunk mintájának kiválasztása során. Ugyan az empirikus vizsgálat az EU tevékenységének elemzésére irányul, nem tekinthető problémának az EU-s definíció mellőzése, hiszen az EU közvetlenül az OECD, közvetetten pedig a Világbank megfogalmazására támaszkodik. A dolgozat későbbi részeiben kizárólag az EU-val sajátos kapcsolattal rendelkezö ACP-országokat, valamint a legkevésbé fejlett országokat és az olajexportőröket különítjük majd el e csoporton belül.

\subsection{FEJLŐDÉS-GAZDASÁGTANI KERET}

Annak érdekében, hogy a fejlődő országok gazdasági fejlődésének vizsgálata során megfelelően járjunk el, elengedhetetlen elemzésünk elméleti kereteinek lefektetése, amihez a fejlődés-gazdaságtan megfelelő kiindulópontot jelent. A második világháború végére tehető a fejlődés-gazdaságtan mint a közgazdaságtudomány egyik tudományágának kialakulása, és az elmúlt több mint fél évszázadban számos elmélet látott napvilágot az elmaradottság, a gazdasági alulfejlettség okainak vizsgálata során, melyek jelentősen befolyásolták nemcsak az egyes államok ténykedési körét, hanem a nemzetközi szervezetek fejlesztési akcióit is. Hiszen ezek az elméletek az elmaradottság általános magyarázata mellett a fejlödési iskolák képviselői stratégiát, javaslatokat is próbálnak adni arra vonatkozóan, hogy a kevésbé fejlett országok miként tudnának kitörni a szegénységből (Acemoglu 2010, Gilpin 2006, Ros 2008, Rostow 1990, Szentes 2002).

Az évtizedek során több ellentétes nézet alakult ki: hol belső, hol külső tényezőket említettek meg a fejlődő országok elmaradottságához vezető faktorok között, valamint hol nagyobb, hol kisebb szerepet tulajdonítottak az állami beavatkozásnak. Ennek következtében rendkívül széles és sokszínü az elméleti háttere. Mivel a mérés alapja az elméleti alap, így nehézzé válik a fejlödés egységes és széles körben elfogadott indikátorokkal történő számszerüsítése. Ugyan hosszú áttekintést lehetne adni a fejlődés-gazdaságtan elméleteiről, ettől jelen dolgozatban eltekintünk. Ennek oka egyrészt az, hogy a fejlödés-gazdaságtan elméleteiről már többen adtak kritikai áttekintést (2.2. táblázat). Másrészt pedig az, hogy a dolgozat célja szempontjából célravezetőbb az, ha ezen elméletek összegzését vesszük alapul, és meghatározzuk, hogy mely keretek között dolgozunk a későbbiekben, és arra helyezünk nagyobb hangsúlyt, hogy a fejlődő országok elmaradottságához milyen tényezők vezettek. E tényezők ismertetése során - felületesen ugyan, de - utalunk a fejlődés-gazdaságtani elméletekre is. 
2.2. táblázat A fejlődés-gazdaságtan elméletei néhány kiemelt szerző művében

\begin{tabular}{|c|c|}
\hline Szerzők & Csoportosítás módszere (ha nincs: kiemelt személyek) \\
\hline $\begin{array}{l}\text { Dutt és Ros } \\
\text { (2008) }\end{array}$ & $\begin{array}{l}\text { klasszikus fejlődéselméletek; függőségi elméletek; strukturalizmus; marxizmus; } \\
\text { intézményi fejlődés-gazdaságtan; neoklasszikus fejlődés-gazdaságtan }\end{array}$ \\
\hline Gilpin (2006) & $\begin{array}{l}\text { fejlődés-gazdaságtan felemelkedése és halála; neoliberalizmus; fejlesztő állam } \\
\text { elmélete }\end{array}$ \\
\hline $\begin{array}{l}\text { Paragi et al } \\
(2007)\end{array}$ & $\begin{array}{l}\text { klasszikus; strukturalista és függóségi; neoliberális fordulat; intézmények és } \\
\text { kontextus-függőség }\end{array}$ \\
\hline $\begin{array}{l}\text { Piasecki és } \\
\text { Wolnicki (2004) }\end{array}$ & $\begin{array}{l}\text { neoklasszikus elméletek (P. Bauer, T. Schultz, J. Meade, G. Meier, H. Bruton); } \\
\text { strukturális egyenlőtlenségek elméletei (H. Chenery, J. Nugent); radikális és marxista } \\
\text { elméletek (P. Baran, G. Frank, S. Amin, G. Palma) }\end{array}$ \\
\hline Ranis (2004a) & $\begin{array}{l}\text { korai háború utáni egyezség; a washingtoni konszenzus; a „,mindenre válasz” } \\
\text { keresése }\end{array}$ \\
\hline $\begin{array}{l}\text { Rees és Smith } \\
(1998)\end{array}$ & Rostow, Fisher-Clark elmélete, Lewis, Myrdal, Todaro \\
\hline $\begin{array}{l}\text { Szakolczai } \\
(2006)\end{array}$ & $\begin{array}{l}\text { elsô generáció (II. világháborútól az első olajválságig); második generáció } \\
\text { (olajválságtól az ezredfordulóig); harmadik generáció (napjaink) }\end{array}$ \\
\hline $\begin{array}{l}\text { Szentes }(2002, \\
\text { 2011) }\end{array}$ & $\begin{array}{l}\text { Négy időszak: (1) 1940-es évek vége - 1960-as évek közepe; (2) 1960-as évek } \\
\text { közepe - 1970-es évek közepe, vége; (3) 1970-es évek közepe/vége - 1990-es évek } \\
\text { eleje; (4) a kommunista rezsimek összeomlása (1980-as évektől napjainkig) } \\
\text { Elméletek: keynesiánus növekedési modellek; neoklasszikus irányzat; strukturalista } \\
\text { és függőségi iskolák; reformista és radikális irányzatok; neoliberális monetarizmus; } \\
\text { egyéb új irányzatok; új intézményi közgazdaságtan; „,közösségi választás elmélete” } \\
\text { és az, „új politikai gazdaságtan” }\end{array}$ \\
\hline $\begin{array}{l}\text { Todaro és } \\
\text { Smith (2009) }\end{array}$ & $\begin{array}{l}\text { klasszikus lineáris növekedési modellek (Rostow); strukturális változások modelljei } \\
\text { (Lewis); nemzetközi függőség (neogyarmati, duális fejlődés); neoklasszikus } \\
\text { ellenforradalom (washingtoni konszenzus) }\end{array}$ \\
\hline
\end{tabular}

A fejlődés-gazdaságtani elméletek főbb jellemzőit a Dutt és Ros (2008), a Piasecki és Wolnicki (2004), illetve a Szentes (2011) által meghatározott csoportokat követve, valamint kiegészítve a Paragi és szerzőtársai (2007) által meghatározott, a Todaro és Smith (2009) szerzőpároséhoz jelentős mértékben hasonlító csoportok figyelembe vételével összegeztük (2.3. táblázat). Ezek alapján bizonyos, hogy a kevésbé fejlett országok elmaradottsága okainak vizsgálata során az egymást nagyjából egy-egy évtizedenként váltó elméletek között megtalálható mind az internalista, mind az externalista megközelítést. Azaz a nemzeti sajátosságok, szerkezeti problémák mellett a nemzetközi folyamatok hatásai is megjelennek az elmaradottság magyarázó tényezői között.

Az elméleti iskolák a fejlődéshez szükséges állami segítséget különböző módon ítélték meg az elmúlt évtizedekben, és jelentős ingadozás figyelhető meg. Míg az 1950-es években a klasszikusok az erőteljes állami beavatkozást tartották a kiút lehetséges módjának, addig az 1960-70-es években jelentős változás történt: a neoklasszikusok azt javasolták, hogy az állam maradjon a háttérben, és ne okozzon több kárt. A napjainkban jelentős szerepet játszó elméletekkel kapcsolatban új következtetést levonni nem lehet: lényegében a korábbiakat 
„veszik elő”, de finomítják az akkori megközelítéseket. Ez szükséges is - egyrészt a korábbi elméletek kritikái miatt, másrészt pedig a megváltozott nemzetközi környezet miatt.

2.3. táblázat A fejlődés-gazdaságtan elméleti felfogásai

\begin{tabular}{|c|c|c|c|c|}
\hline & Klasszikus iskola & $\begin{array}{c}\text { Függőségi és } \\
\text { strukturalista } \\
\text { elméletek }\end{array}$ & $\begin{array}{l}\text { Neoklasszikus } \\
\text { iskola }\end{array}$ & $\begin{array}{c}\text { Intézményi } \\
\text { kontextus, újabb } \\
\text { felfogások }\end{array}$ \\
\hline Időszak & 1950-es évek & 1960-as évek & $\begin{array}{l}\text { 1970-es évek, 1980- } \\
\text { as évek }\end{array}$ & $\begin{array}{l}\text { 1990-es évek } \\
\text { második felétől }\end{array}$ \\
\hline $\begin{array}{l}\text { Elmaradottság } \\
\text { jellemzői }\end{array}$ & $\begin{array}{l}\text { internalista; } \\
\text { keynsiánus alap; } \\
\text { fejlődés: } \\
\text { unilineáris } \\
\text { folyamat; } \\
\text { ördögi kör, } \\
\text { kumulatív okság }\end{array}$ & $\begin{array}{c}\text { externalista; } \\
\text { elmaradott gazdasági } \\
\text { szerkezet, romló } \\
\text { cserearány; } \\
\text { centrum } \\
\text { kizsákmányolja a } \\
\text { perifériát } \\
\end{array}$ & $\begin{array}{c}\text { internalista; } \\
\text { elégtelen állami } \\
\text { beavatkozás az } \\
\text { elmaradottság oka; }\end{array}$ & $\begin{array}{l}\text { internalista és } \\
\text { externalista; } \\
\text { emberi fejlődés } \\
\text { koncepciója; } \\
\text { vallás szerepe }\end{array}$ \\
\hline $\begin{array}{l}\text { Megoldási } \\
\text { javaslatok }\end{array}$ & $\begin{array}{l}\text { külső segítség } \\
\text { ösztönzése }\end{array}$ & $\begin{array}{c}\text { importhelyettesítő } \\
\text { politika; } \\
\text { NIEO }\end{array}$ & $\begin{array}{c}\text { exportösztönző } \\
\text { politka; washingtoni } \\
\text { konszenzus }\end{array}$ & $\begin{array}{l}\text { nemzetközi } \\
\text { kereskedelem; } \\
\text { intézményi } \\
\text { fejlesztés; } \\
\text { poszt-washingtoni } \\
\text { konszenzus }\end{array}$ \\
\hline Állam szerepe & $\begin{array}{c}\text { eröteljes állami } \\
\text { beavatkozás }\end{array}$ & $\begin{array}{c}\text { erőteljes állami } \\
\text { beavatkozás }\end{array}$ & $\begin{array}{c}\text { állam háttérbe } \\
\text { vonulása }\end{array}$ & $\begin{array}{l}\text { állam mérsékelt } \\
\text { szerepvállalása }\end{array}$ \\
\hline $\begin{array}{l}\text { Nemzetközi } \\
\text { kereskedelem } \\
\text { szerepe }\end{array}$ & támogatás & $\begin{array}{l}\text { függőségi irányzat: } \\
\text { elkerülni, } \\
\text { importhelyettesítés }\end{array}$ & exportösztönzés & $\begin{array}{l}\text { globalizáció, } \\
\text { nemzetközi } \\
\text { kereskedelem } \\
\text { fontos }\end{array}$ \\
\hline $\begin{array}{l}\text { Főbb } \\
\text { képviselőik }\end{array}$ & $\begin{array}{c}\text { Myrdal, } \\
\text { Rosenstein- } \\
\text { Rodan, Rostow, } \\
\text { Lewis, Kuznets, } \\
\text { Solow }\end{array}$ & $\begin{array}{l}\text { Prebisch, Singer, } \\
\text { Wallerstein, Amin }\end{array}$ & Williamson, Lal & North, Sen, Stiglitz \\
\hline
\end{tabular}

Forrás: saját szerkesztés

$\mathrm{Az}$ állam szerepvállalása mellett a nemzetközi kereskedelemben való részvétel előnyeinek, hatásainak megítélése is folyamatosan változott. Ugyan a klasszikusok alapvetően támogatták a nemzetközi kereskedelemben való részvételt és a más országokból érkező támogatásokat pozitívnak ítélték, Myrdal ezzel ellenkező állásponton volt: szerinte a kereskedelemből nyerhető haszon rendkívül egyenlőtlenül oszlik meg (Streeten 1998, Szentes 2002, 2011). A legnagyobb váltás e téren a függőségi iskola és a neoklasszikus iskola között található: az importhelyettesítő, a fejlett országoktól teljesen elzárkózó politikát felváltotta a nyitottságon alapuló, exportösztönző stratégia. ${ }^{21}$ Mindez a mai napig megmaradt, viszont napjainkban a nyitottság kérdése nem pusztán önálló döntés, hanem bizonyos szempontból kényszer is, hiszen például a Kereskedelmi Világszervezet egyezményei nyomán a be- és

\footnotetext{
${ }^{21}$ E két, a kereskedelem és fejlődés kapcsolatát - eltérően - megítélő elméletet a 3.2. fejezetben részletezzük.
} 
elzárkózás lehetetlennek tünik, bár a regionális integrációkkal - amelyeknek többnyire szabad kereskedelem a végső célja - próbálnak ellene küzdeni.

Az elméleti iskolák áttekintése alapján elfogadható, hogy a fejlődő országok elmaradottságának magyarázatát illetően mindegyik elméletnek megvan a maga erőssége és igazsága (a maga korlátja mellett), azonban az iskolák között néhol ellentmondás található, néhol pedig kiegészítik egymást. Ebből kifolyólag az elmaradottsághoz vezető okokat illetően nem lehet egységes álláspontot megfogalmazni, viszont egyértelmü, hogy az országok elmaradottságában országon belüli (nemzeti sajátosságok) és országon kívüli (nemzetközi folyamatok) egyaránt szerepet játszanak (Lawal 2006, Szentes 2011, SzentIványi 2009b).

Ennek ismeretében fontos további elemzésünk elméleti keretének meghatározása. Napjainkban annyira erősek a gazdasági kapcsolatok az egyes országok között, valamint a nemzetközi szervezetek erőteljes fellépése nyomán a globalizáció folyamata és a nemzetközi kereskedelem olyan mértékü, hogy - a függőségi iskola által javasolt - elzárkózás egyszerüen nem járható út. Az 1990-es évek közepe óta a nemzetközi kereskedelemre és befektetésekre úgy tekintenek, mint a neoliberális modell vitathatatlan bizonyítékai (Piasecki és Wolnicki 2004). Ennek következtében ebben az időszakban, de még napjainkban is uralkodó fejlődési paradigmának tekinthető, hogy a nyitottság, a globalizáción és a regionális integráción keresztüli fejlődés „elhozza” a fejlődő országok felemelkedését (Piasecki és Wolnicki 2004). Ezt a felfogást, azaz hogy a fejlődő országok kitörési lehetőségeinek vizsgálata során egyre nagyobb szerepet kap a nemzetközi kereskedelemben való aktív szerepvállalás, napjainkban számos nemzetközi szervezet (pl. ENSZ, UNCTAD, EU) hangsúlyozza. ${ }^{22}$ Így a dependencia-elméletek és a kereskedelmi pesszimizmus kora lejárt, és új irányba haladunk. Azonban úgy tünik, mintha némileg megint a (neo)klasszikusokhoz nyúlnának vissza, de az intézményi közgazdaságtan adta lehetőségeket is figyelembe véve. Ez utóbbit igazolja az is, hogy a legtöbbször elismerik azt, hogy a nemzetközi kereskedelemben való részvétel önmagában nem fogja megoldani a problémákat, szükséges az intézményi háttér fejlesztése is.

Összességében tehát ma már teljesen új gazdasági környezet és új jellegü gazdasági folyamatok határozzák meg egy ország (gazdasági) fejlődését, melyben a gazdasági (kereskedelmi, pénzügyi) nyitottság fontos tényezővé vált. Így ha a fejlődő országok fejlődési lehetőségeit vizsgáljuk, ezt a tényezőt nem szabad figyelmen kívül hagyni. Ebből következően elfogadjuk a neoklasszikusok azon következtetését, miszerint a nemzetközi

\footnotetext{
${ }^{22}$ Lásd részletesen a dolgozat 3.2.4. fejezetében.
} 
kereskedelemben való részvételt, a kifelé tekintő (outward) politikát erösíteni kellene a gazdasági fejlődés érdekében. Kiegészítve azzal, hogy az intézményi közgazdaságtan állításait is figyelembe vesszük, így elfogadjuk, hogy a fejlődéshez megfelelő intézményi háttér is szükséges. Ezzel pedig elutasítjuk a neoklasszikusok azon vélekedését, mely szerint a nem megfelelő állami beavatkozás és a hibás gazdaságpolitikai lépések következtében fellépő piaci tökéletlenségek miatt a kormányzatnak vissza kellene vonulnia és teret kellene hagynia a piacnak (Gilpin 2006, Paragi et al 2007, Rashid 2008). Érvelésünket igazolja az is, hogy a 2000-es évek óta a washingtoni konszenzus ${ }^{23}$ már-már feledésbe merült, és Broad (2004) tanulmánya alapján paradigmaváltás zajlik. Stiglitz (olyan közgazdászokkal együtt, mint $D$. Rodrik vagy $P$. Krugman) új ajánláscsomagot fogalmazott meg: a poszt-washingtoni konszenzus a korábbi szabadpiaci megközelítéssel ellentétben elismeri az állam szerepét a gazdaságban (Öniş és Şenses 2005, Sumner 2006). Az államnak ma már szerepet kellene vállalnia a pénzpiac szabályozásában, a technológiai fejlesztésekben és azok terjesztésében, a humán tőke fejlesztésében, az infrastruktúra kiépítésében, valamint a szegénység csökkentésében is (Öniş és Şenses 2005).

Az elméleti keret meghatározása során ki kell térni arra is, hogy a fejlödés fogalmát milyen megközelítés szerint használjuk. A fejlődésnek számos vetülete van (gazdasági, társadalmi, politikai, intézményi, kulturális) (Leeson és Nixson 2004), jelen dolgozatban kizárólag a gazdasági vetületével, a gazdasági fejlődés kérdéseivel foglalkozunk. Ennek fényében a dolgozat további részeiben a fejlődés alatt a gazdasági fejlődést fogjuk érteni, bár tisztában vagyunk a kettő közötti különbséggel. Ehhez legközelebb a Világbank 1991-es World Development Report kiadványában megfogalmazott gazdasági fejlődés fogalma áll (Világbank 1991, 31. o.): „,az életszínvonal fenntartható növekedése, mely magában foglalja az anyagi fogyasztást, oktatást, egészséget és környezetvédelmet.” A fejlődés általános céljai között pedig a gazdasági, politikai és civil jogok bővülése szerepel, melyek minden ember számára elérhetővé válnak. A fejlődés jellemzői közül az alábbi tényezőket emeli ki a jelentés (és Naqvi (1996) is hasonlóan fogalmaz):

\footnotetext{
${ }^{23}$ Fejlesztéspolitikai ajánláscsomag elsősorban Latin-Amerika országai számára (McCleery és de Paolis 2008, Williamson 1994). A név onnan ered, hogy három washingtoni intézmény, a Világbank, az IMF és az amerikai jegybank (Fed) magáénak érezte és alkalmazta ezeket az elveket (Paragi et al 2007). A tíz pontot lásd részletesen Williamson (1994) müvében.
} 
- a fejlödés az egy före jutó jövedelemmel megközelíthető, fontos a gazdasági növekedés; ${ }^{24}$

- strukturális transzformáció, azaz az output szektorális megoszlásában történt változás;

- humán tőke fejlödése;

- nemzetközi munkamegosztásban való részvétel, a kereskedelem szerepe;

- az oktatás, technológia és a nyitottság a fejlődéssel komplex kapcsolatban állnak;

- makrogazdasági stabilitás;

- külső, világgazdasági tényezők (például cserearány, nemzetközi kamatláb, tökeáramlás, fejlett (OECD) országok növekedése) hatásai.

A gazdasági fejlődés e megközelítése azért fontos, mert egyrészt ezen tényezőkkel maga a gazdasági fejlődés könnyebben megragadható, másrészt pedig későbbi (empirikus) elemzésünknél az indikátorok kiválasztása során jelentenek támpontot. Mivel a fejlődést több tényező befolyásolja, így fontos a fejlődő országok elmaradottságához vezető tényezőket részletesen áttekinteni. Ezek egyrészt a nemzetközi közösség beavatkozásának szükségességére világítanak rá, másrészt hozzájárulnak ahhoz, hogy a beavatkozási lehetőségeket megfelelő módon értékeljük.

\subsection{A FEJLŐDŐ ORSZÁGOK ELMARADOTTSÁGÁHOZ VEZETŐ TÉNYEZŐK}

A következőkben a fejlődés-gazdaságtan elméletei, valamint a releváns szakirodalmi áttekintés alapján meghatározzuk azokat a tényezőket, melyek a fejlődő országok elmaradottságához vezettek. Ennek ismerete támpontot ad arra vonatkozóan, hogy milyen területen szükséges a külföldi beavatkozás, egyáltalán szükség van-e rá. A relatív elmaradottsághoz vezető tényezőket több szerző többféle módon határozta meg, illetve csoportosította (Csáki 2002, Egedy 2007, Ghosh 2008, Goldin és Reinert 2007, Kebonang 2007, Krugman és Obstfeld 2003, Lawal 2006, Myrdal 1957, Nafziger 2006, Szentes 1976, 1999, 2002 és 2011, Varsádi 1984), ezeket figyelembe véve és kiegészítve egyéb tényezőkkel, egyszerű csoportosítást használtunk. A faktorokat két csoportba rendeztük, és az externalisták és internalisták megközelítése, valamint Szent-Iványi (2009b) és Szentes (2011) hasonló hozzáfüzése alapján - az elmaradottság országon belüli (mint nemzeti sajátosság) és országon kívüli tényezőire (nemzetközi folyamatok) osztottuk (2.4. táblázat). A belső tényezők között a gazdasági és társadalmi problémák mellett a politikai (intézményi)

\footnotetext{
${ }^{24}$ Fontos megemlíteni, hogy a gazdasági növekedés nem minden esetben történik jól. A gazdasági növekedés mellett nem biztos, hogy nő a munkahelyek száma, nem biztos, hogy hosszú távon fenntartható, vagy nem egyenlően oszlik meg a lakosságon belül. Ezen növekedésekröl lásd részletesen az UNDP (1996) kiadványát.
} 
akadályok is megtalálhatók, míg a külső tényezők között a nemzetközi kereskedelemmel (munkamegosztás), a külföldi közvetlen beruházással és a függőséggel kapcsolatos hátrányok emelhetők ki.

2.4. táblázat A fejlődő országok elmaradottságához vezető tényezők

\begin{tabular}{|c|c|c|c|}
\hline $\begin{array}{c}\text { Fejlődés- } \\
\text { gazdaságtan }\end{array}$ & \multicolumn{2}{|c|}{ Csoportosítás } & Tényezők \\
\hline \multirow{15}{*}{ 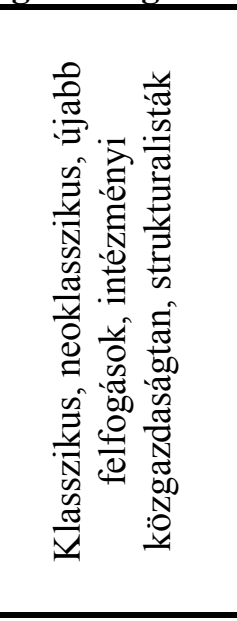 } & \multirow{15}{*}{ 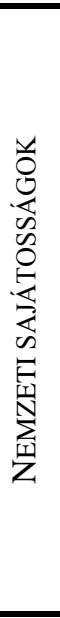 } & Gazdasági & Kedvezőtlen éghajlati viszonyok, természeti erőforrások hiánya \\
\hline & & & Alacsony jövedelem, alacsony tőkefelhalmozás és befektetés \\
\hline & & & Gazdaság duális és dezintegrált szerkezete \\
\hline & & & Infrastruktúra kiépítetlensége, intézmények hiánya \\
\hline & & & Szük belső piac \\
\hline & & & Importhelyettesítő gazdaságpolitika és monopol struktúra \\
\hline & & & Tőke- és technológiahiány \\
\hline & & & Elhibázott kormányzati politika \\
\hline & & Társadalmi & Népességrobbanás, urbanizációs problémák (nyomornegyedek) \\
\hline & & & Oktatás, egészségügy, infrastruktúra fejletlensége \\
\hline & & & Kulturális örökség, vallási hagyományok \\
\hline & & & Társadalom dezintegrált szerkezete, társadalmi különbségek \\
\hline & & Politikai & Politikai bizonytalanság \\
\hline & & & Fejletlen intézményi háttér \\
\hline & & & Egypárt-rendszer, diktatúra \\
\hline \multirow{7}{*}{ 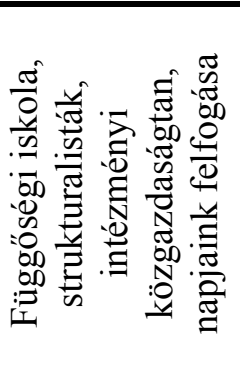 } & \multirow{7}{*}{ 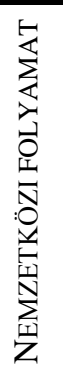 } & Nemzetközi & Gyarmati típusú munkamegosztás \\
\hline & & kereskedelem & Elmaradott áruszerkezet, romló cserarány \\
\hline & & & Import- és exportkényszer \\
\hline & & Külföldi tőke & Közvetlen külföldi beruházás enklávé és duális jellege \\
\hline & & & \\
\hline & & Függőség & Aszimmetrikus interdependencia \\
\hline & & & Alacsony tárgyalási erő a nemzetközi kapcsolatokban \\
\hline
\end{tabular}

Forrás: saját szerkesztés

A külső és belső tényezők nem választhatók el élesen egymástól. Ebböl kifolyólag kiemelendő, hogy a külső tényezők között az országon kívül vezérelt faktorokat szerepeltetjük: külső irányítással történnek, és az ország nem tudja befolyásolni. Ezért bár az FDI hatása némileg hasonló a belső tényezők között szereplőkkel, mégis érdemes elkülönülten és a külső tényezők között szerepeltetni. Mivel már a tényezők felületes áttekintése során is elfogadható, hogy egyes tényezők között ok-okozati kapcsolat van, és mivel ezekre a faktorokra a későbbiekben többször utalunk, a pontos kép kialakítása érdekében szükséges részletesebben is áttekinteni ezeket. Hangsúlyozandó, hogy bár a következőkben az általános vonásokat emeljük ki, mégsem mondható az, hogy minden tényező minden fejlődő országban ugyanolyan szerepet játszott elmaradottságuk kialakulásában (Szentes 2011). 


\subsubsection{A NEMZETI SAJÁTOSSÁGOK SZEREPE A FEJLŐDŐ ORSZÁGOK ELMARADOTTSÁGÁBAN}

Az elmaradottság belső tényezői közül a gazdasági tényezőkhöz kötődően ki kell emelni a természeti kincsekkel való ellátottságot, illetve az éghajlati viszonyokat. Számos fejlődő ország sivatagos területen fekszik, ezáltal a termelés lehetőségei az éghajlat, valamint a talajminőség miatt korlátozottak. Sok fejlődő ország természeti erőforrásokban szegény, ha mégis megtalálható, akkor nem képesek azt hatékonyan (és fenntartható módon) felhasználni (Szentes 1976). Azonban nem kizárólag a természeti erőforrások hiánya, hanem azok bősége is a gazdasági fejlődés akadálya lehet. Amellett, hogy többnyire nem hatékony a kitermelés, Collier (2008) kifejti, hogy a természeti kincsekkel való ellátottság sok esetben akár fejlődési csapda is lehet egy országban: ha jól jövedelmező forrásról van szó (mint például az olaj), akkor az ország gazdasági szempontból elkényelmesedhet, és a normális gazdasági tevékenység folytatását nem tartja szükségesnek, ennek következtében exportja sem nem diverzifikálódik ${ }^{25}$, sem nem lesz versenyképes a nemzetközi piacokon. Ndikumana és Abderrahim (2010) afrikai, latin-amerikai, közel-keleti és ázsiai fejlődő országok esetében vizsgálták a természeti erőforrásokkal való ellátottság és a kormányzati bevételek alakulása közötti kapcsolatot. Eredményeik szerint az afrikai erőforrásokban gazdag országok rosszabbul teljesítettek mind az erőforrásokkal kevésbé jól ellátott, mind az olajban gazdag közel-keleti országokhoz képest. Ennek oka feltételezhetően az intézményi háttér különbségeiben keresendő. Mindebből következően sem a természeti erőforrásokkal való ellátottság, sem pedig annak hiánya nem lehet a fejlődő országok elmaradottságának kizárólagos oka (Szentes 1976, 2011), de mindenképpen lehet erre a faktorra okként tekinteni.

Sok fejlődő országra jellemző, hogy az országban lévő, exportorientált szektor (ami akár FDI-ra is épülhet, de attól független is lehet) a nemzetgazdaság egészétől elzártan müködik (enklávé, sziget), nem támogatva az egész gazdaság fejlődését. ${ }^{26}$ Ebből következően ez a „sziget” fejlettebb a többi régiónál, az ebből a szektorból kiszorulók (a hagyományos szektorban, mezőgazdaságban dolgozók) elszegényednek, ugyanis a hagyományos iparágak és termékeik nem versenyképesek (Krugman és Obstfeld 2003). Ezzel lényegében a klasszikusok - de különösen Arthur Lewis - által elemzett dualizmus kérdéséhez jutunk el (Ranis 2003, 2004a). Lewis feltételezései szerint ugyanis a gazdaság egy hagyományos és egy modern szektorra osztható, ahol a hagyományos szektor elsősorban alacsony termelékenységü

\footnotetext{
${ }^{25}$ Például az olajban gazdag Nigéria, Csád és Szaúd-Arába exportkoncenrációs indexe sorrendben $0,85,0,71$ és 0,69, ahol az 1 jelenti a maximális koncentrációt (UNCTAD 2011).

${ }^{26}$ Hasonló folyamat játszódik le a külföldi tőke esetében is, amit a külső tényezők tárgyalása során részletezünk.
} 
mezőgazdaságra épül, míg a modern szektor ipari jellegü magasabb termelékenységgel, városias jelleggel (Krugman és Obstfeld 2003, Rees és Smith 1998, Szentes 2002).

Lewis elmélete szerint a dualizmus problémája megoldható úgy, ha a hagyományos szektorban lévő munkaerö-többlet hajlandó elmenni a városba dolgozni a magasabb jövedelemért (Cypher és Dietz 2004, Rees és Smith 1998). ${ }^{27}$ Ezek alapján az iparosodás hozzájárulhat a fejlődéshez. Azonban egy új iparág kialakulása - Myrdal érvelése szerint káros is lehet a hagyományos tevékenységekre nézve, hiszen versengeniük kell a tömegtermeléssel (Rees és Smith 1998), és ahelyett, hogy a pozitív hatásuk leszivárogna a rurális területekre, ún. „backwash” (visszaható) hatás jelenik meg (Streeten 1998), és a növekedés a vidéki területek fejlődésének kárára valósul meg (Rees és Smith 1998). A gazdasági szerkezetben lévő dualizmus pedig továbbra is fent marad. Ennek megoldása ezek ismeretében is nehéz, de a külföldi hitelek, illetve segélyek is többnyire a relatíve fejlett ágazatokba áramlanak a hatékonyabb felhasználás reményében (Szentes 2011), ezzel pedig tovább nő a gazdaság két része (szektora) közötti szakadék.

A fejlődő országok elmaradottságához hozzájárul a szük belső piac is. Sok terméket ugyanis többnyire a szük gazdag-, elitréteg tud megvásárolni, hiszen az alacsony egy főre eső jövedelem miatt az országban alacsony a fizetőképes kereslet. Így sok termelő belföldön el sem tudja adni termékét, a külpiacokon viszont nem versenyképes. Emellett a gazdasági fejlődést ellehetetleníti a vállalatok közötti verseny teljes vagy részleges hiánya, melynek következtében a monopolstruktúra az uralkodó ezekben az országokban (Szentes 1999). A monopolstruktúra fennmaradását segíti (segítette) elő az, hogy a fejlődő országok többsége Latin-Amerikában, Ázsiában, majd később Afrikában is - a függőségi iskola ajánlásainak megfelelően - importhelyettesítő gazdaságpolitikát folytatott (Levy-Orlik 2009, Palma 2008b, Rodrigues 2010), ezáltal a verseny hiánya, valamint a technológiai fejlődés kényszerének elmaradása a gazdasági fejlődés alapjait nem teremtette meg. ${ }^{28}$ Továbbá, az importhelyettesítő politika következtében olyan feldolgozóipari egységek jöttek létre, melyek elsősorban az elitréteg igényeinek kielégítésére törekedtek (Szentes 2011).

Emellett a közlekedési hálózat (út, vasút) nem megfelelő minőségü, akadozik a víz- és energia-szolgáltatás, még ott is, ahol már kiépült, ezzel pedig maga az egészséges élet, illetve

\footnotetext{
${ }^{27}$ Lewis megközelítését több kritika is érte (Ranis 2003, 2004b, Rees és Smith 1998): egyrészt a hagyományos ágazatban bizonyos időszakokban (például vetés vagy aratás idején) növekedhet a munkaerő iránt a kereslet, másrészt Lewis nem jól becsülte meg a vidékről való elvándorlás mértékét, ahogy a bérkülönbségeket sem (Rees és Smith 1998).

${ }^{28} \mathrm{Az}$ importhelyettesítő gazdaságpolitika hátterét és következményeit a dolgozat 3.2.1. fejezetében részletezzük.
} 
- a munka oldaláról nézve - a vállalkozás is akadályokba ütközik. További hátrány, hogy az infrastruktúra fejlesztése elsősorban az enklávészektor igényeinek való megfelelést jelenti, tovább erősítve a dualizmust. Az egészségügyi ellátórendszer, az infrastruktúra hiányosságai, valamint a szegénység következtében a fejlődő országok többségében a ma már megelőzhető és gyógyítható betegségek (mint például malária, tbc) is jelentős áldozatokkal járnak, de az AIDS terjedése is jelentősen rombolja a munkaképes korú népesség egészségi állapotát, amit tetéz a gyógyszerhez való hozzájutás problémája is (Gathii 2007, Udvari 2011a, WHO 2009).

A helyzet megváltoztatása és a gazdasági fejlődés érdekében viszont tőkére, illetve nagyobb arányú megtakarításra lenne szükség. Azonban az egy före eső jövedelem lassú növekedése következtében alacsony a köz- és a magánszféra megtakarítási szintje, valamint a politikai instabilitás is csökkenti az állami megtakarításokat (Edwards 1996), így tőkefelhalmozás nem kezdődhet el. Az alacsony egy főre eső jövedelem és a politikai instabilitás nem kizárólagos tényezői az alacsony belső megtakarítási rátának ${ }^{29}$, a külső adósságállomány is negatívan hat annak alakulására (Okafor és Tyrowicz 2010), valamint a szociális intézményi háttér kiépítetlensége is befolyásolja (például Kína). Mindezek következménye egyértelmüen a tőkehiány, viszont ennek következtében a modern technológia is hiányzik a fejlődő országokban.

A társadalmi problémák közül a népességrobbanás okoz jelentős gondot, hiszen a rendkívül nagymértékű népességnövekedés következtében számos fiatal nem tud munkához jutni, illetve egyes esetekben munkaerő-hiányról is beszélhetünk, ugyanis képzettségi szintjük alacsony. Amennyiben mégis magasabb képzettségi szinttel rendelkeznek, fennáll a brain drain veszélye, vagyis az, hogy a fejlett országokban keresnek munkát (Mountford és Rapoport 2011, Weinberg 2011). A relatíve alacsony képzettségi szint mellett az egészségügyi rendszer és a helytelen higiénés szokásaik következtében egészségi állapotuk is korlátozza munkavállalásukat. Mivel a nemzeti jövedelem nem arányosan nő a népességgel, egyes országokban, különösen a legkevésbé fejlett (a fejlődési csapdába került) országokban bővül a szegények, a napi 1-2 dollárnál kevesebből élők köre (Collier 2008). ${ }^{30}$ Ez pedig a lakosság korösszetétele is jelentős terhet ró az államra: magas a gyermek-, alacsony a

\footnotetext{
${ }^{29}$ Erre nagyon jó példa Kína: magas megtakarítási rátával rendelkezik az alacsony egy före eső jövedelem ellenére. Ennek hátterét lásd részletesen például Ang (2009), illetve Gábor (2009) tanulmányában.

${ }^{30}$ Bár összességében, globálisan a szegénység csökkenéséről lehet beszélni, viszont ez elsősorban a nagy országok statisztikai hatásának tudható be. Ugyanis Kínában jelentősen sikerült csökkenteni az arányukat (Khin 2010, Ravallion 2009). Az ún. PICNI (Pakisztán, India, Kína, Nigéria, Indonézia) országok adatait kivéve a statisztikákból, lényeges (statisztikailag szignifikáns) különbség nem található a szegények számában az 1990-es és a 2008-as adatokat összevetve (Glennie 2011), mindemellett a világ szegényeinek háromnegyede a közepes jövedelmü országokban található (Summer 2010).
} 
munkaképes korúak aránya (Szentes 1976). Egyes vélemények szerint pedig a politikai instabilitás miatt hadsereg fenntartására van szükség, és a katonai létszám szinten tartása miatt a kormány nem feltétlenül érdekelt a népességnövekedés ütemének csökkentésében, ezáltal (is) kiszorítva a nőket a termelésből (Lehmijoki és Palokangas 2006).

A modernizációt gátolja az a tény is, hogy a fejlődő országokban élők ragaszkodnak a hagyományaikhoz, és idegenkednek az újdonságoktól (Szentes 1999). A társadalom szétzilálását erősíti a jelentős mértékü jövedelemegyenlőtlenség az országon belül: egyes társadalmi rétegek nagyon meggazdagodtak (luxuscikkeket is megvásárolni képes elitréteg), míg mások a nyomorba kerültek (napi 1-2 dollárból tengődők), melynek okai között egyrészt a duális gazdaság, másrészt pedig a politikai rendszer is megemlíthető. Továbbá ezekben az országokban gyakorinak mondható az emberi és állampolgári jogok megsértése, a nők diszkriminálása (Lehmijoki és Palokangas 2006).

A politikai tényezők közül maga a politikai instabilitás emelhető ki. A legtöbb fejlődő országban a demokratikus politikai berendezkedés hiánya és a többnyire egypárt-rendszer, diktatúra dominanciája a jellemző. Már a klasszikusokhoz tartozó Myrdal is megkülönböztette a gyenge (soft) és az erős (hard) államot: míg a fejlett országokban erős állam van, addig a fejlődő országokban a gyenge állam a jellemző, és ez akadályozza a fejlődésüket (Cypher és Dietz 2004). A folytonos bizonytalanság, elnyomás következtében ugyanis egyre gyakoribbak a belpolitikai háborúk: a világ legszegényebb egymilliárd fős népességének több mint 70 százaléka vagy a közelmúltban élt át polgárháborút, vagy még napjainkban is fegyveres konfliktusban él (Collier 2008). A gyenge állam folyományaként pedig különböző erőszakos módon keresik megélhetésüket az emberek. Ez utóbbira nagyon jó példa Szomália, ahol a nemzetközi hatásokkal bíró - kalózkodás az 1990-es évek elején romba dőlt szomáli állam bukására vezethető vissza (Shortland 2011, Shorthland és Vothknecht 2011). A belháborúk pedig negatívan hatnak az ország fejlődésére: egy egy évig tartó polgárháború átlagosan 2,3 százalékkal csökkenti a gazdasági növekedést, csökken a munkaképes korú lakosság száma, az egészségügyi rendszer összeomlása és az emberek migrációja miatt megnő a járványok veszélye, megváltozik a nők helyzete, félbeszakad az oktatás (Collier 2008, Világbank 2011c). Továbbá minél nagyobb a belső konfliktus kialakulásának kockázata, annál nagyobb hadsereget kell fenntartani (Lehmijoki és Palokangas 2006), aminek egyrészt költségvonzata is van, illetve - ahogy arra már korábban utaltunk - a népességnövekedésre is hatása lehet. 
A fejlődő országok elmaradottságát magyarázza az intézmények ${ }^{31}$ alulfejlettsége is. Az intézményi közgazdaságtan képviselői az elmaradottság okaként a piaci intézmények hiányát, a magas tranzakciós költségeket és a járadékvadászat jelenlétét nevezi meg (Jameson 2008). Ebből kifolyólag minden ország olyan sajátos fejlődési úttal rendelkezik, amiben a kormányzati politikának, illetve a társadalmi magatartásnak is jelentős szerepe van (Szentes 2011). Az intézmények szerepe, hatása olyan jelentős, hogy például Easterly és Levine (2003) kimutatták, hogy a természeti tényezőkkel való ellátottság (például kedvező mezőgazdasági adottság) kizárólag az intézményeken keresztül hat a gazdasági fejlődésre, e nélkül nem tudtak kimutatni szignifikáns hatást. Ugyanígy, Acemoglu és szerzőtársai (2001) az intézményeknek kiemelt hatást tulajdonítanak az egy före jutó jövedelem növekedésére.

Valószínüleg a nemzetközi terrorizmus nyilvánvaló jelenléte és a szeptember 11-i amerikai események miatt a vallás egyre inkább a politikai kérdések közé került. Ezzel szinte párhuzamosan ma már a vallás fejlődésben és gazdasági teljesítményben betöltött szerepét is vizsgálják. Már a fejlesztéssel foglalkozó nemzetközi szervezetek is - úgy, mint a Világbank, vagy az IMF - fejlesztéseik során a vallási sajátosságokra is tekintettel vannak (Ter Haar és Ellis 2006). Az elemzések is azt mutatják, hogy ha nem kellő körültekintéssel veszik figyelembe ezeket a jellemzőket, akkor negatívan befolyásolhatja a gazdasági fejlődést. Noland (2005) például az iszlám vallás gazdasági teljesítményben betöltött szerepét vizsgálta ökonometriai módszerekkel, és eredményei szerint kimutatható az iszlám vallás és a gazdasági növekedés közötti pozitív kapcsolat. Ter Haar és Ellis (2006) mindezt összekapcsolják az emberi fejlődés dilemmájával, és kiemelik, hogy a fenntartható fejlődés csak úgy érhető el, ha minden ember a saját erőforrásaira támaszkodik - azonban ez nemcsak intellektuális és társadalmi forrásokat jelent, hanem spirituálisokat is. A szerzők Afrika példáján viszik végig ezt a vonalat, és végső konklúziójuk szerint a vallás és annak elismerése pozitívan hat a fejlődésre, így Afrika fejlesztésénél is figyelni kellene erre.

A keleti államok (mint például India vagy Burma) sajátosságait veszi figyelembe a buddhista közgazdaságtan: mivel teljesen más gazdasági berendezkedésűek, mint a nyugati államok, számukra, a buddhista országok számára nem alkalmasak a nyugati gazdasági modellek (Zsolnai 2010). A buddhista közgazdaságtan szerint a helyi igényeket helyi

\footnotetext{
${ }^{31}$ North $(1991,97$. o.) úgy fogalmazza meg az intézményeket, mint ,emberek által alkotott korlátok, amelyek szabályozzák köztük a gazdasági, politikai és társadalmi interakciókat”, és kiemeli, hogy egyaránt vannak informális (például tabu, hagyomány, szokás) és formális akadályok (például alkotmány, tulajdonjog).
} 
forrásból kellene kielégíteni, ezzel pedig az importtól való függést elutasítják, és ugyanígy elvetik az exportra való termelést is. ${ }^{32}$

Az országon belüli tényezők fontossága Sen humán fejlődés koncepciójában is megjelenik. Sen (2003) szerint a szegénység a képességek hiányát jelenti, és a fejlődéshez elengedhetetlen a humán tőke. Az elmélet szerint a fejlődés annyit tesz, hogy a különféle szabadsághiányok forrásait felszámoljuk: csökkentjük a szegénységet, megszüntetjük a kizsákmányolást, bővítjük a szükös gazdasági lehetőségeket, fellépünk az elnyomó államok intoleranciája ellen, valamint nagyobb szerep jutna a közintézményeknek is. A Sen-féle elmélet szerint a bruttó nemzeti jövedelem (GNI) növekedése, az iparosítás, valamint a technológiai haladás kizárólag eszközei lehetnek a fejlödésnek, azaz annak, hogy a társadalom tagjai által élvezett szabadságok bővülnek (Pataki 1998, Sen 2003).

\subsubsection{AZ ELMARADOTT ORSZÁGOK FEJLŐDÉSÉT BEFOLYÁSOLÓ NEMZETKÖZI}

\section{FOLYAMATOK}

Az elmaradottsághoz hozzájáruló nemzetközi folyamatok a nemzetközi kereskedelem szerepe meghatározó. A fejlődő országok nemzetközi kereskedelemben való részvételét erősen befolyásolta a gyarmati időszak során kialakult ún. gyarmati típusú nemzetközi munkamegosztás, mely során a gyarmattartó országok a gyarmataikról nyersanyagot, mezőgazdasági termékeket és élelmiszert szereztek be, és a gyarmattartóik ipari termékeinek felvevő piacai lettek. Ehhez erősen kapcsolódik a strukturalista iskola képviselőinek nézete, mely szerint a világgazdaság két részre osztható: a centrumra és a perifériára, ahol a centrum homogén és diverzifikált, míg a periféria heterogén és specializált (Palma 2008a). A periféria azért heterogén, mert az exportszektora magas, míg a mezőgazdasága alacsony munkatermelékenységgel rendelkezik; illetve az exportszektor néhány primer termék termelésére koncentrál és enklávé-szerüen müködik, valamint meglehetősen kevés (elöre- és hátrafelé irányuló) kapcsolata van a gazdaság többi részével (Palma 2008a, Szentes 2011). A strukturalisták úgy vélik, hogy a fejlődő országok hátrányos helyzete ennek az elmaradott gazdasági szerkezetnek tudható be, melynek következtében nem tudnak hatékonyan részt venni a nemzetközi munkamegosztásban, és így a

\footnotetext{
32 Mindemellett a buddhista közgazdaságtan az emberi fejlődés koncepciójához is hasonlítható, hiszen a gazdasági növekedést nem fogadja el, és elsődleges céljának az érintettek jól-létét tekinti, és úgy akarja a megélhetést biztosítani, hogy közben csökkenti az emberek és a nem emberi lények szenvedését (Puntasen 2010). A buddhista közgazdaságtan fejtegetése nem tartozik szorosan a dolgozat témájához. Részletesen lásd Zsolnai (2010) tanulmánykötetét, vagy Daniels (2005) tanulmányát a témával kapcsolatosan.
} 
világkereskedelem a centrum számára sokkal nagyobb hasznot jelent, mint a periféria számára (Palma 2008a, Paragi et al 2007).

Következésképpen ez a fajta munkamegosztás a gyarmattartó és gyarmatbirodalma között a gyarmatot meglehetősen hátrányosan érintette (a fejlett ország, a ,hatalom” kizsákmányolta), és a gyarmat erősen kiszolgáltatottá vált korábbi gyarmattartójának, így függőség alakult ki (Szentes 1999). Viszont néhány kutatás azt is kimutatja, hogy a gyarmati kereskedelmi rendszerek eltünőben vannak: mind a gyarmat és a gyarmattartó, mind pedig a „gyarmattestvérek” közötti kereskedelem csökkent a függetlenné válás után (Head et al 2010). Továbbá Collier (2008) utal arra, hogy a fejlődő országok ma már nem kizárólag nyersanyagok exportőrei, viszont a neokolonializmust elfogadók szerint a volt gyarmatok kiszolgáltatottsága megmaradt a nagyobb hatalmak (nemzetközi (pénzügyi) intézmények és szervezetek) irányába, amelyek nem csak a korábbi gyarmattartók köréből kerültek ki (Hanson és Hentz 1999, Stoneman és Suckling 1987).

Összességében a fejlődő országok kiszolgáltatottságát növeli az exportra szánt termékeik elmaradottsága, hiszen a korábbi gyarmatok jellemzően egy-egy (elsősorban mezőgazdasági) termékre szakosodtak. Ebből következően a fejlődő országokat hátrányosan érinti a világpiaci árak változása. A Prebisch-Singer tétel szerint ugyanis hosszú távon romlik a primer termékek cserearánya az ipari termékekkel szemben, következésképpen a déli (azaz fejlődő) országok cserearánya kedvezőtlenebbül alakul az északi (fejlett) országokéhoz képest (Chen és Sapsford 1997, Palma 2008a, Sarkar 2001). Ennek következtében a déli (kevésbé fejlett) országok kereskedelmi helyzete hátrányos: lényegében a szegényebb országokból a gazdagabb országokba áramlik a jövedelem (Todaro és Smith 2009). ${ }^{33}$ A romló cserearány pedig negatívan hat a gazdasági növekedésre, ha olyan termékek relatív ára csökken, mely exportja kiemelkedő az ország számára (Cashin et al 2004), valamint a külkereskedelmi mérleg alakulására is negatív hatással van (Otto 2003).

Senstho (2003) azonban botswanai vizsgálatai során arra jutott, hogy a nyersanyagok exportja is okozhat gazdasági növekedést, igaz, erre úgy kell tekinteni, mint az iparra és a szolgáltatásokra történő áttérés, ami a hosszú távú növekedés alapja lehet. A nemzetközi munkamegosztásból viszont nem maradhatnak ki a fejlődő országok, hiszen az országok nagy része kénytelen exportálni és importálni is. Ennek oka, hogy be kell szerezni azokat az ipari

\footnotetext{
${ }^{33}$ Bár 2007-2008-as élelmiszerválság idején az élelmiszer, illetve néhány nyersanyag ára rendkívüli módon megemelkedett, az országoknak mégsem kedvezett ez a folyamat az országon belüli szegények aránya miatt, akik így már az alap élelmiszerekhez is drágábban juthattak hozzá (Timmer 2010).
} 
termékeket és technológiát, illetve szolgáltatásokat, melyeket maguk nem tudnak előállítani ezek beszerzési költségeit viszont csak az exportból befolyó jövedelemből tudják fedezni. Mindemellett a duális gazdaság problémája sem választható el ettől a kérdéstől, ugyanis a modern, exportszektor mellett fennmaradt egy gyenge mezőgazdasági szektor is, ebből kifolyólag ezek a rétegek nem élvezhetik a külkereskedelemből nyerhető többlethasznokat (Szentes 2011).

A belső tényezők között szereplő tőkehiány orvoslására a közvetlen külföldi beruházás sem megoldás, ugyanis néhány ország/régió (Mexikó, Délkelet-Ázsia), illetve természeti kincsekben gazdag ország (mint például Angola) kivételével a külföldi befektetések aránya nagyon alacsony a fejlődő országokban (Al-Khaldi 2008, Collier 2008, UNCTAD 2010). A tőke nem a leginkább a rászoruló országokba áramlik a magas kockázat, az információhiány, a politikai hitelesség hiánya miatt (Collier 2008, Todaro és Smith 2009). Ha mégis megtörténik, akkor többnyire az enklávé és dualitás lesz jellemző: egyrészt a betelepült külföldi cég nem kapcsolódik be az ország gazdasági életébe (szigetként müködik), magas importhányaddal dolgozik, csak kihasználja az olcsó munkaerőt, és a gyártott terméket exportálja, ráadásul az esetek többségében profitrepatriálás (profitkivonás az országból) történik (Mészáros 2011, Szentes 2011). Másrészt az a jellemző, hogy csak az ország egy részén valósulnak meg a külföldi beruházások, az ország ezen része fejlődik, míg az ország többi részén többnyire alacsony színvonalú mezőgazdaságból próbálnak megélni az emberek. ${ }^{34}$ Mindezek alapján pedig elfogadható, hogy az enklávé illetve a dualitás egymást erősítik (Mészáros 2004). Továbbá azt is meg kell említeni, hogy vannak olyan empirikus kutatások (például Herzer et al 2008), amelyek megkérdőjelezik az FDI gazdasági növekedésre gyakorolt hatását a fejlődő országokban, viszont az sem egyértelmü, hogy az FDI nélkül nem lenne-e rosszabb a helyzet ezekben az államokban.

A fejlődő országok kedvezőtlen világgazdasági helyzetét a perifériás helyzetük, illetve az aszimmetrikus interdependencia (függőség) tovább rontja, és a fejletlen országokat hátrányosan érinti a fejlett országoktól való kereskedelmi, pénzügyi (eladósodás) és technológiai függőség (Szentes 2011). Továbbá a fejlődő országok egyoldalúan a fejlett

\footnotetext{
${ }^{34}$ Ez pontosan megfigyelhető Kína esetében is: a tengerparton, az ország keleti részében létrehozott különleges gazdasági övezetek nyomán és a beáramló külföldi tőke hatására (is) az ország ezen része sokkal fejlettebb, mint az ország belsö, nyugati területe (Chen 2010, Csanádi et al 2009), bár mára a fejlettebb tengerparti sáv szélesedett (Csanádi et al 2009).
} 
országoknak, és az azok által generált folyamatoknak vannak kitéve (alárendelt szerepben) a kereskedelmi, pénzügyi, technikai és más gazdasági kapcsolatok területén. ${ }^{35}$

Az elmaradottság, fejletlenség mögött meghúzódó külső és belső tényezők rávilágítanak az országok gazdasági lehetőségeire, valamint gazdasági fejlődésük korlátaira. Ezen tényezők (okok) mérséklése, megoldása egyenként is nehéz feladat, azonban további nehézséget okoz, hogy ezekre a tényezőkre teljes mértékben ráillik az ördögi körök elmélete (circulus vitiosus). Azaz az egyes okok egy másik ok okozatává válnak (Csáki 2002, Gore 2002, Myrdal 1957, Nafziger 2006, Szentes 2002 és 2011), ezzel pedig átfogó beavatkozásra lenne szükség. Bár az ördögi körök elméletének jogosultságát kétségbe vonják (lásd például Nafziger (2006), illetve Szentes (2002) munkáit), véleményünk szerint mégis megfelelően írja le az elmaradottság tényezői közötti összefüggéseket. Ezt nevezhetjük fejlődési csapdának is, ahol a konfliktusok, természeti erőforrásokkal való el (nem) látottság, a szárazfölddel körülvettség rossz szomszédokkal, valamint a rossz kormányzás járulnak hozzá a csapda kialakulásához és fennmaradásához (Collier 2008). Összességében azt sugallják, hogy a nemzetközi közösség beavatkozása az elmaradott országok számára rendkívüli fontossággal bír. További vizsgálódásaink szempontjából fontos az is, hogy a fejlesztési politika csak abban az esetben lehet sikeres, ha a belső tényezők mellett az elmaradottság külső okainak felszámolására, korrigálására is törekszenek, azaz egy ország fejlődése során a belső (gazdasági és társadalmi) integrálódás mellett fontos a külső (világgazdasági) integrálódás is (Szentes 2011). Ezek ismeretében pedig megalapozódik a nemzetközi kereskedelem szerepének vizsgálata a fejlesztés(i együttmüködés) témakörében.

E fejezet rávilágított arra, hogy a fejlődő országok elmaradottsága többek között a tőkehiánynak is köszönhető, így érdemes megnézni azt, hogy milyen pénzügyiforrás-bevonási lehetőségek állnak a fejlődő országok rendelkezésére. A dolgozat következő részében két kérdést járunk körül: az egyik a nemzetközi fejlesztési együttmüködés adta lehetőségek, a másik pedig a nemzetközi kereskedelemben való részvétel erősítése. Ezek során azt elemezzük, hogy a külföldi segítség milyen körülmények között járulhat hozzá a gazdasági fejlődéshez. Nem feledve azt, hogy a nemzetközi integrálódás támogatásának eszközei lehetnek egyrészt a szerződéses formában nyújtott kereskedelmi preferenciák, a dolgozat 4.2. és 4.3. fejezetében részletesen vizsgáljuk ezt a lehetőséget is az Európai Unió vonatkozásában. Másrészt a konkrét kereskedelemfejlesztést célzó fejlesztési támogatások is a

\footnotetext{
${ }^{35}$ Az aszimmetrikus függőségről lásd részletesen például Szentes (2011) munkáját.
} 
nemzetközi kereskedelmi szerepvállalást javíthatják, ami napjainkban az Aid for Trade programon keresztül jelenik meg, és amelyet a dolgozat következő fejezetében fejtünk ki bővebben, valamint az EU tevékenységét elemezzük ezen a téren az 5.3. és 5.4. fejezetben. 


\section{A NEMZETKÖZI SEGÉLYEZÉS ÉS A NEMZETKÖZI KERESKEDELEM}

\section{SZEREPE}

A nemzetközi közösség - országok és nemzetközi szervezetek egyaránt - már több évtizede igyekszik a fejlődő országok problémáját orvosolni. Jelen dolgozatban két területet emelünk ki: a nemzetközi segélyezés (fejlesztési együttmüködés) dilemmáit, valamint a nemzetközi kereskedelem gazdasági fejlődésben betöltött szerepét. A fejezet végén pedig az Aid for Trade lehetőségeit ismertetjük. Tisztában vagyunk azzal, hogy ennél több eszköz áll rendelkezésre (például technikai segítségnyújtás), illetve más lehetőségek is befolyásolhatják a folyamatokat (például külföldi tőkeáramlás), valamint egyéb pénzszerzési források is rendelkezésre állnak (például hazautalások). Viszont ezek az értékezés céljától messze vinnének, így ismertetésükre e dolgozat keretei között nem térünk ki.

\subsection{A NEMZETKÖZI FEJLESZTÉSI EGYÜTTMÜKÖDÉS FŐBB DILEMMÁI}

Az elmúlt évtizedek során a nemzetközi fejlesztési segélyezés szakirodalma rendkívül széles lett, így számos kutatás található a segélyezés és a gazdasági növekedés, fejlődés közötti kapcsolat meglétének igazolására, esetlegesen megcáfolására vonatkozóan. Ugyan a dolgozat fő témája nem a segélyezéshez kapcsolódik, viszont a kérdés nem kerülhető meg két okból. Egyrészt a fejlődő országok mozgásterének, gazdasági lehetőségei fejlesztésének elsődleges eszköze a nemzetközi fejlesztési segélyezésben (együttmüködésben) rejlett. ${ }^{36}$ Másrészt a dolgozat empirikus vizsgálatának egyike az Aid for Trade kezdeményezésre irányul, ami a fejlődő országok kínálatoldali kapacitásának fejlesztését célzó pénzügyi támogatás. Ezek alapján fontos megérteni a(z általános) segélyezés hatékonysága kapcsán felmerülő kérdéseket. Így a teljesebb kép érdekében kitérünk a segélyezés legfontosabb kérdéseire: milyen lehetőségei és veszélyei vannak a nemzetközi segélyezésnek a fogadó ország szempontjából, milyen tényezőkre vezethető a segélyek alacsony hatékonysága, milyen körülmények között müködhet eredményesen a segélyezés, valamint mely országokat kellene támogatni. Hangsúlyozzuk, hogy mivel a segélyezés irodalma meglehetősen szerteágazó, nem törekszünk a teljes irodalom áttekintésére, mindössze az a célunk, hogy rámutassunk a dilemmákra, ezzel is megalapozva helyes empirikus kutatás elvégzését.

\footnotetext{
${ }^{36}$ Nem szabad azonban elfelejteni azt sem, hogy a fejlődés-gazdaságtan különböző iskolái másképp vélekedtek a segélyek szerepéről. Míg a klasszikusok támogatták ezt a forrást (Streeten 1998, Szentes 2002, 2011), addig a függőségi elméletek képviselői szerint a segélyezés a kizsákmányolás egy formája (Streeten 1983). Valamint az Új Nemzetközi Gazdasági Rend kialakításában is hangsúlyozták azt, hogy a fejlett országoknak pénzügyi és technológiai forrásokat kellene a szegény országokba eljuttatni (Vanasse 1988).
} 


\subsubsection{A FEJLESZTÉSI EGYÜTTMÜKÖDÉS LEHETŐSÉGEI ÉS VESZÉLYEI}

A nemzetközi fejlesztési segélyezés intézménye a második világháború után alakult ki a Marshall-segély, a fejlődő országok dekolonizációja és a fejlődés-gazdaságtan mint tudományág kialakulásának következtében (Szent-Iványi 2009b), viszont nagyobb teret csak az 1960-as években nyert (Doucouliagos és Paldam 2007). A fejlesztési segélyezés létét lényegében a fejlett és a fejlődő országok között kialakult fejlődési szakadék indokolja, és létrejötte mutatja azt, hogy a mai világgazdaság müködésében zavarok vannak (Szent-Iványi 2009b). Azonban a segélyezés helyett ma már a fejlesztési együttmüködés a leginkább használt fogalom a jelenség leírására, ami magában foglalja a hivatalos fejlesztési támogatásokat (Boros 2005). A nemzetközi fejlesztési segélyezésben a nemzetközi szervezetek - úgy, mint a Világbank, az IMF, az OECD Fejlesztési Bizottsága, az ENSZ egyes szakosított szervei kiemelkedő és koordináló szerepet játszanak, csakúgy, mint a donorországok. Bár e szervezetek, országok fejlesztési tevékenysége (és kritikája ${ }^{37}$ ) érdekes téma, viszont messze vinne jelen értekezés fö kérdésétől és céljától, így ezen intézmények tevékenységének ismertetését e dolgozatban hanyagoljuk.

A segélyek hatékony felhasználásról, valamint veszélyeiről átfogó képet ad a World Development Report 1991. évi kiadása (Világbank 1991) (3.1. táblázat). A segélyek pozitív hatása lehet a gazdasági reformok hitelességének növelése, hiszen a reformcsomagokhoz pluszforrást biztosít. Emellett a forrásigényes infrastrukturális fejlesztések végrehajtásához is hozzájárulhat, valamint a munkaerő képzettségi szintjét is javíthatja. Továbbá a környezet megóvásában, valamint a szegénység csökkentésében is jelentős szerepet játszhatnak, ezzel is biztosítva a kedvezőbb gazdasági és szociális politikák kialakítását.

Amennyiben a segélyeket nem hatékonyan használják fel, akkor az számos veszélyt rejt magában, és több kárt okoz, mintha nem is lettek volna ezek a támogatások. Viszont fontos az a tény, hogy nem kizárólag a fogadó országok lehetnek hibásak: egyrészt a donorok motivációja és lehetőségei jelentősen befolyásolják a segélyek összegét, emiatt a fogadó ország számára ez nem lehet biztos és kiszámítható forrás. Másrészt a donorok, bilaterális intézmények az idők folyamán más-más fejlesztéspolitikai elveket követtek, így például a korábban támogatott importhelyettesítő gazdaságpolitika felváltása akár csak egy alacsonyabb vámszinttel, már relatíve jelentős költségeket ró a fogadó országokra - holott ők csak az

\footnotetext{
37 A leggyakoribb kritikát a washingtoni konszenzus elemeihez (különösen a privatizáció, a liberalizáció, a dereguláció, a szigorú költségvetés fenntartása) kötött segélyezésük miatt kapták (kapják) (Broad-Cavanagh 1999, Gilpin 2006, Held 2005, Sandbrook 2005, Stiglitz 2003). Számos közgazdász kritizálja ennek eredményességét, lásd például Irogbe (2005), Piasecki és Wolnicki (2004), vagy Stiglitz (2003) elemzését.
} 
ajánlásokat követték. Mindemellett a fogadó ország hozzászokhat a segélyekhez és segélyfüggővé válhat ${ }^{38}$, így fejlesztési programokat, gazdasági reformokat halaszt el, nem ösztönzi a belföldi megtakarítások növekedését (bár ideiglenesen helyettesítheti azt (McGillivray et al 2005)), és kizárólag a segély révén jutnak külföldi valutához.

3.1. táblázat A segélyek veszélyei, illetve lehetséges pozitív hatásai

\begin{tabular}{cc}
\hline A segélyek veszélyei & A segélyek pozitív hatásai \\
\hline $\begin{array}{c}\text { hazai források mobilizálásának és } \\
\text { makrogazdasági menedzsment fejlesztésének } \\
\text { elodázása }\end{array}$ & növeli a gazdasági reformok hitelességét \\
\hline $\begin{array}{c}\text { megtakarítások, kereskedelmi áramlások, FDI, } \\
\text { kereskedelmi tőke helyettesítése }\end{array}$ & $\begin{array}{c}\text { beruházások forrása, ha más forrásból nem lehet } \\
\text { finanszírozni a súlyos adósság miatt }\end{array}$ \\
\hline $\begin{array}{c}\text { nem elörejelezhető és kiszámítható forrás } \\
\text { nem koordinált bilaterális támogatások } \\
\text { egymásnak ellentmondóak is lehetnek }\end{array}$ & $\begin{array}{c}\text { infúra fejlesztéséhez, a személyzet } \\
\text { (tovább)képzéséhez hozzájárul }\end{array}$ \\
\hline $\begin{array}{c}\text { a donorok változó politikája növeli a fogadó } \\
\text { országok költségeit, esetlegesen a korrupciót }\end{array}$ & $\begin{array}{c}\text { hazai politikák, intézmények, adminisztratív } \\
\text { kapacitás növelik a segélyek hatékonyságát }\end{array}$ \\
\hline
\end{tabular}

Forrás: saját szerkesztés Világbank (1991) alapján

Bár már több mint ötven éve biztosítanak különféle pénzügyi (fejlesztési) forrásokat a fejlődő országok számára, a segélyezés nem tekinthető sikeresnek, hiszen egyrészt már évtizedek óta konfliktusforrásnak tekinthető a segélyezés kötöttsége, politikai feltételei, bilaterális volta miatt (Simai 1981), másrészt pedig fél évszázad alatt nem sikerült a világgazdaságban lévő egyenlőtlenséget felszámolni (Szent-Iványi 2009b). Az adatokat tekintve, 60 év alatt egyedül csak a Világbank több mint 2,3 billió dollár fejlesztési támogatást juttatott a fejlődő országokba (Weller és Yi-Chong 2009), illetve a külföldi segélyek a fejlődő országok GDP-jének átlagosan 12,5 százalékát teszik ki (Irandoust és Ericsson 2005), a szegénység azonban még mindig komoly probléma ezekben az országokban. Összességében a segélyezés csekélyebb eredménnyel járt, mint ahogy sokan várták: például Fekete-Afrikában a GNI arányában a hivatalos fejlesztési támogatások dinamikusan növekedtek az 1970-es évek óta, azonban a térségben az egy före jutó GDP az 1970-es szinthez képest alig változott ${ }^{39}$ (3.1. ábra).

\footnotetext{
${ }^{38}$ Míg a legtöbb fejlődő régióban a segély/GNI arány 1 százalék alatt volt, Fekete-Afrikában meghaladta a 6 százalékot (Holland 2008), egyes országokban pedig 20 százalék fölött volt (Moss et al 2006).

${ }^{39}$ Természetesen vannak pozitív tapasztalatok is. Például Al-Khaldi (2008) Jordániát vizsgálta empirikus úton, és eredményei szerint a beérkező fejlesztési támogatásoknak pozitív hatása van az ország gazdasági fejlődésére.
} 
3.1. ábra A GDP/fó és a segélyezés alakulása Fekete-Afrikában, 1970-2009

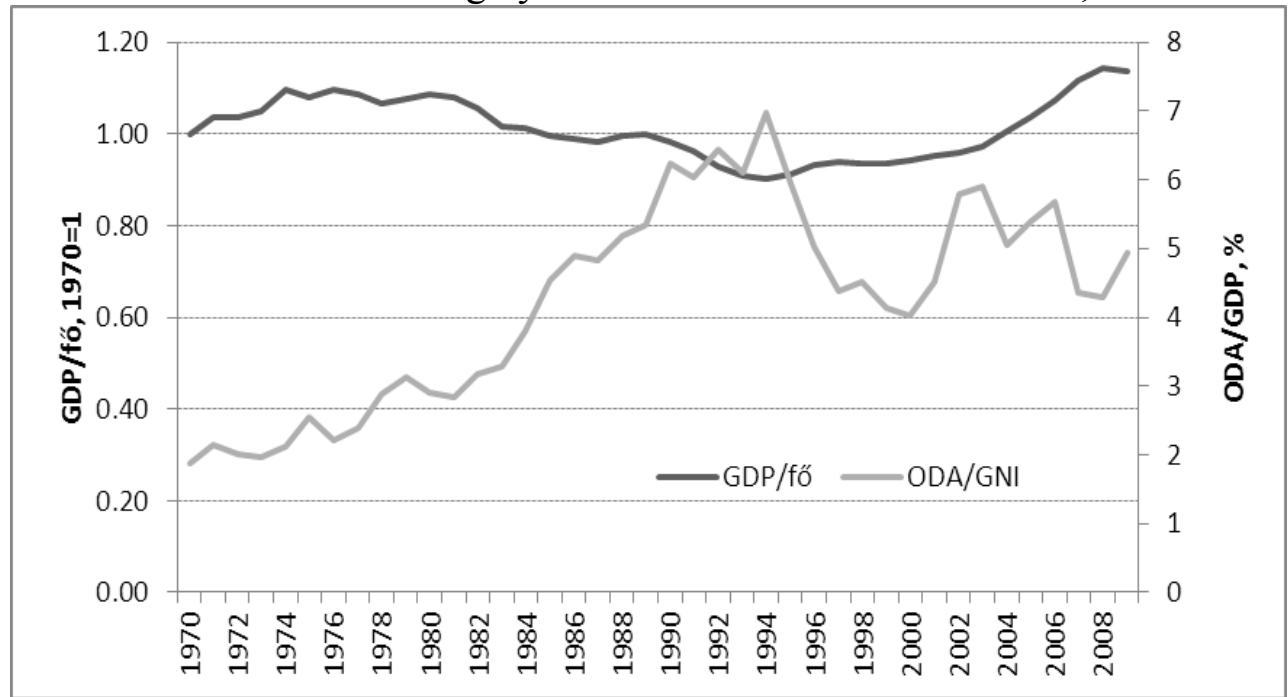

Megjegyzés: ODA: hivatalos fejlesztési támogatás (official development assistance)

Forrás: saját szerkesztés a Világbank (2011b) adatai alapján

Mindez pedig megkérdőjelezi a nemzetközi fejlesztés szükségességét, sikerességét. Talán emiatt is fordul egyre nagyobb figyelem más, alternatív lehetőségek felé. Viszont nem lehet figyelmen kívül hagyni azt a tényt sem, hogy nem kizárólag a segélyezés tényével vannak problémák, hiszen maga a fogadó ország felkészületlensége is szerepet játszhat az alacsony hatékonyságban. Erre mutat rá az is, hogy a fejlesztési együttmüködés előtt mára új kihívások jelentek meg, hiszen az ún. bukott államok fejlesztése lett az elsődleges cél (SzentIványi 2006). Így a következőkben azt nézzük meg, hogy milyen tényezők befolyásolhatják a segélyek hatékonyságát, valamint a legújabb kutatások alapján összegezzük, hogy milyen tényezők megléte járulhat hozzá az eredményesebb segélyfelhasználáshoz.

\subsubsection{A SEGÉLYEZÉS HATÉKONYSÁGA}

A fejlesztési segélyek hatékonyságát, a gazdasági növekedésre és fejlődésre, tőkevonzásra gyakorolt hatását számos tényező befolyásolja. Ennek következtében még ma is vita folyik arról, hogy a fejlesztési segélyeknek vajon van-e érdemi hatásuk a gazdasági növekedésre és a strukturális átalakulásra (Abegaz 2005, Kosack 2003, White 1992). Egyes kutatók pozitív kapcsolatot találtak a segélyek és a gazdasági növekedés között (például Irandoust és Ericsson 2005, Loxley és Sackey 2008), míg mások egyáltalán nem találtak szignifikáns kapcsolatot (például Burke és Ahmadi-Esfahani 2006, Rajan és Subramanian 2008). Ennek okaira egyrészt a fentebbi, 3.1. táblázatban szereplő tényezők, másrészt pedig az alábbi elemzések eredményei alapján következtethetünk. 
A nemzetközi fejlesztési segélyezés irodalmának rendkívül széles áttekintését adja Doucouliagos és Paldam (2007), akik a 2004-es évvel lezárulóan összesen 97 ökonometriai elemzésre épülő, a segélyek hatékonyságának vizsgálatával foglalkozó tanulmányt tekintettek át. E kutatások alapján a szerzők végkövetkeztetése, hogy a segélyezés az általuk vizsgált 40 évben nem volt hatékony, és szerintük a holland kór ${ }^{40}$ jelensége jelentősen befolyásolta a segélyek felhasználásának hatékonyságát. Rajan és Subramanian (2011) elemzésük során kifejezetten a holland kór jelenségére fókuszáltak. Eredményeik szerint a segélyek negatívan hatnak a fogadó ország exportjára: romlik a versenyképessége elsősorban a reálárfolyam felértékelődése következtében. A szerzők ezzel magyarázzák azt, hogy hosszú távon miért nem lehet sikeres a segélyezés a fogadó ország gazdasági növekedése elérése érdekében. Collier (2008) mindezt úgy fogalmazza meg, hogy a segély és az export egymás „versenytársa”, a kettő nem müködhet együtt, hiszen a segély - a fentebb leírt folyamaton keresztül - képes kiszorítani az exportot.

A segélyek változékonysága, volatilitása is komoly problémát jelent: ha nem kiszámítható a segély nagysága már egy-egy projekt megvalósítása során sem, akkor nehéz bármilyen reformot, bármilyen (humán tőke és infrastrukturális) fejlesztést megvalósítani (Moreira 2010). Bulir és Hamann (2008) elemzése szerint a segélyek ingadozása sokkal nagyobb mértékü, mint a belföldi bevételeké (adók), és így a nagyon szegény, segélyfüggő országok nem tudnak helyes makrogazdasági politikát folytatni. Hudson és Mosley (2008) viszont már megkülönbözteti a segélyáramlás pozitív és a negatív irányú ingadozását, bár a segélyek mindkét irányú ingadozása csökkenti a gazdasági növekedésre gyakorolt hatását. A szerzők eredményei szerint ugyanis mind a pozitív, mind a negatív volatitlitás negatív hatással van a beruházásokra és a kormányzati kiadásokra. Továbbá ugyan a negatív irányú ingadozás növeli a fogyasztási kiadások arányát a GDP-ben, ez nem tekinthető olyan jelentős hatásnak, hogy ellensúlyozza a GDP egyéb komponenseit érintő negatív hatásokat. A pozitív irányú ingadozás az import arányát csökkenti a GDP-ben, így a makrogazdasági egyensúly helyreállításában fontos szerepet játszik.

\footnotetext{
40 Jelentős mértékű segély beáramlása egy országba súlyosbíthatja a makrogazdasági instabilitást az infláció emelkedésén, valamint a reálárfolyam erösödésén keresztül, melynek következtében az ország exportjának versenyképessége romlik (McKinley 2005). A holland kór általános elemzését lásd Kacsirek (1993) tanulmányában.
} 
A segélyek hatékonyságát a küldött összeg is befolyásolja, amit pedig a donorok kötelezettségvállalásának mértéke, motivációja határoz meg. ${ }^{41}$ Az „adakozási kedvet” jelentősen befolyásolja, hogy milyen a fogadó ország felkészültsége, milyen gazdaságipolitikai-biztonsági érdekei vannak a donornak, illetve milyen a (világ)gazdasági környezet. Powell és Bird (2010) ugyanis munkájukban kifejtik, hogy a jelenlegi pénzügyi válság idején a donorok nem fogják növelni a fejlesztési segélyeik összegét, hanem inkább az adósságelengedést tekintik majd a segélyezési politikájuk részének. Megjegyzendő azonban, hogy az adósság-elengedés már korábban is tipikus „,segélyezési” gyakorlat volt, emiatt több kritika is érte a donorokat. ${ }^{42}$

Bár már régóta kétséges a fejlesztési támogatások hatékonysága, és egyre jobban felismerik a lehetséges veszélyeket, a nemzetközi fejlesztési segélyezés kérdése napjainkban a Millenniumi Fejlesztési Célok (MDGs) ${ }^{43}$ megvalósítása miatt még mindig fontos szerepet kap. Rajan és Subramanian (2011) optimistán fogalmaznak: ma már ne az legyen a kérdés, hogy hatékonyak-e a segélyek, hanem sokkal inkább az, hogy hogyan lehetne javítani a felhasználás hatékonyságát. Ugyanis a nemzetközi közösség célja a fejlesztési támogatások további növelése az MDG-k megvalósítása érdekében, és a támogatások elsődleges célpontjának Fekete-Afrikának kellene lennie (Abegaz 2005). Ugyan a Millenniumi Fejlesztési Célok hangzatosak és átfogóak, számos tanulmány kétségbe vonja a célok tarthatóságát, megvalósíthatóságát - a segélyek hatékonysági problémái mellett a megvalósult célok hosszú távú fenntarthatóságát érintő pótlólagos költségei miatt - ami akár további külföldi pénzügyi forrást igényel majd. Dalgaard és Erickson (2009) rámutatnak arra, hogy a segélyek gazdasági növekedésben és szegénységcsökkentésben betöltött szerepét illetően túlzottak voltak a várakozások, így a szerzők nem is tartják reálisnak az MDG-k közül a szegénység csökkentésére vonatkozó célok teljesülését.

Mindemellett a segélyek végtelen mértékü növelése sem lehet hatékony: átlagosan a GDP 15-45 százalékának megfelelő összegü segély esetén a gazdasági növekedés csökkenni fog, és a segély nem éri el a várt eredményt. Ennek oka elsősorban a már említett holland kór jelensége, valamint a fogadó országok korlátozott abszorpciós képessége (McGillivray et al

\footnotetext{
41 A donorok motivációjának részletes áttekintése nem tartozik a dolgozat fó mondanivalójához. Ezek áttekintését lásd részletesen például Paragi és szerzőtársai (2007), Todaro és Smith (2009), illetve Szentes (2005) munkáiban, illetve empirikus úton tesztelve például Younas (2008) tanulmányában.

${ }^{42}$ Lásd például Gunter et al (2008), vagy Powell és Bird (2010). Illetve ennek ellenkezője is megtalálható, lásd például Ndikumana (2004) tanulmányát.

${ }^{43}$ Millennium Development Goals. Az ENSZ 2000-ben fogadta el a Millenniumi Fejlesztési Célokat, melyek összesen nyolc átfogó célt takarnak, és 2015-ös határidővel igyekeznek a fejlődő országok legégetőbb problémáit megoldani, illetve mérsékelni. Az MDG-ről lásd részletesen UN (2000).
} 
2005). Ennek ismeretében felmerülhet a kérdés: lehet-e egyáltalán hatékony a segélyezés? Milyen tényezőktől függ? A dolgozat következő fejezetében ezt a kérdést járjuk körül.

\subsubsection{MIKOR MŰKÖDHET A SEGÉLYEZÉS?}

A múlt század közepe óta egészen az 1990-es évek közepéig a segélyek hatékonysága vizsgálatának középpontjában a különböző növekedési modellek álltak, és annak elemzése, hogy vajon a segélyek hozzájárulnak-e a megtakarítások növekedéséhez, ami pedig a gazdasági növekedés eszköze (McGillivray et al 2005). A Világbank 1998-as Assessing Aid jelentésében megfogalmazott konklúzió - miszerint a good governance fontos tényező hozott változást, és ettől kezdve egyre nagyobb hangsúlyt kapott annak elemzése, hogy milyen háttértényezők, speciális körülmények játszhatnak szerepet a segélyek hatékony felhasználásában (McGillivray et al 2005). Ugyan nincs egyértelmü konszenzus abban, hogy mégis milyen tényezők játszanak szerepet, azonban az intézményi közgazdaságtan állításaival összhangban az intézmények szerepére terelödik a figyelem.

Bár Burnside és Dollar (2000) megközelítését többen kritizálták, a szerzők eredményeit mégis érdemes megemlíteni. Kutatásuk során arra a végeredményre jutnak, hogy a segélyek felhasználása sokkal hatékonyabb olyan országokban, amelyek megfelelő monetáris, fiskális és kereskedelmi politikát folytatnak. Ebből kifolyólag a szerzők azt javasolják, hogy a segélyek allokációját a jó kormányzás feltételéhez kellene kötni, ami manapság többnyire nem jellemző. Collier és Dollar (2001) is az intézményi háttér szerepét hangsúlyozzák: a szegénységcsökkentés és a hatékony segélyfelhasználás érdekében először politikai reformok véghezvitelét javasolják. A szerzők későbbi tanulmányukban - Collier és Dollar (2002) - egyértelmüen megfogalmazzák azt, hogy a szegénységcsökkentési céllal nyújtott segélyek sokkal eredményesebbek lennének a jó kormányzással bíró országokban, viszont - az ő konklúziójuk szerint is - a segélyelosztásban egyáltalán nem döntő fontosságú ez a tényező.

A segélyek hatékonyságát emellett olyan tényezők is befolyásolhatják (és egyesek szerint nagyobb mértékben, mint a gazdaságpolitikák), amelyekre az országnak nincs befolyása - úgy, mint a cserearány változása, a természeti katasztrófák, vagy esetleg az éghajlat (McGillivray et al. 2005). Guillaumont és Chauvet (2001) elemzik mélyrehatóan e tényezők hatásait. A szerzők eredményei szerint a sokkal sérülékenyebb gazdaságokban a segélyek hatékonysága magasabb, és ugyan a különböző politikai akciók jelentősen befolyásolják a növekedést, viszont ezeket a segélyezés nem teszi hatékonyabbá. Ennél 
továbbmenve, Dalgaard és szerzőtársai (2004) szerint az éghajlati tényezők is jelentősen befolyásolják a segélyek hatékonyságát. A szerzők az éghajlatot a trópusi területen elhelyezkedő földterület nagyságával közelítették meg. Empirikus eredményeik arra utalnak, hogy a trópusi területeken kevésbé hatékony a segélyek felhasználása. Ugyanakkor a szerzők azt is elismerik, hogy ez a jelenség az alacsonyabb termelékenység mellett az ezeken a területeken lassabban kiépülő intézményeknek, infrastruktúrának is betudható. Mindez pedig összhangban lehet a gyarmatosítással (és az akkori érdekekkel és lehetőségekkel) is, amit pedig Acemoglou és szerzőtársai (2001) elemeztek.

A segélyek hatékonyságának vonatkozásában nincs egyértelmü empirikus bizonyíték arra, hogy fogadó ország politikai stabilitása és befolyásolhatósága mennyiben hat a segélyek összegére. Islam (2003) a segélyek gazdasági növekedésre gyakorolt hatását elemezte a politikai rezsim függvényében. Eredményei szerint a segélyek pozitív hatással bírnak a gazdasági növekedésre az erős diktatorikus országokban, mint a gyengébb diktatúrával rendelkező országokban. Kosack (2003) viszont azt hangsúlyozza, hogy a segély a demokratikus berendezkedésü országokban sokkal hatékonyabb, mint az autoriter rendszerekben, és a szerző szerint inkább a demokratizálódási folyamatot kellene támogatni. Kalyvitis és Vlachaki (2011) eredményei szerint viszont a segély negatívan hat a fogadó országra abból a szempontból, hogy ott demokrácia alakuljon ki, azaz a segélyekkel nem lehet demokráciát kiépíteni. Ennek oka lehet a korrupció is. Alesina és Weder (2002) a korrupció és a segélyek közötti kapcsolat feltárására tettek kísérletet. Eredményeik szerint nincs összefüggés a korrupció mélysége és a segélyek nagysága között: nem tudták bizonyítani azt, hogy a kevésbé korrupt kormányok több pénzügyi forrást kaptak volna. Islam (2003) viszont kimutatta, hogy a korrupció jelentős szerepet játszik a segélyek kifizetésében a gyengébb vezetésủ országokban, mint a totális diktatúrákban. Azaz a korrupció ugyan a segélyek mennyiségére nem, de annak hatékony felhasználásban jelentős szerepet játszik.

Scheiring (2010) a segélyek hatékonyságának javítása érdekében több tényezőt emel ki. Véleménye szerint a fejlesztési segélyek növelésére van szükség (ami ellentmond a korábbiakban kifejtettekkel, és amivel a fentebb kiemelt intézményi hiányosságok miatt nem értünk egyet), össze kell hangolni a segélyek prioritásait az MDG-vel, valamint a humán fejlődéssel, csökkenteni kellene a hadászati kiadásokat, hiszen ma már más jellegü biztonságpolitikai kihívással találkozunk. Továbbá új, innovatív finanszírozási formákat (mint például kötvények kibocsátása, Tobin-adó, repülőjegyek megadóztatása) kellene bevezetni, így a segélyek növelése könnyebben és gyorsabban elérhető lenne, valamint az adósság- 
elengedésre több hangsúlyt kellene helyezni. A sok projektalapú támogatást a programalapú segélyezésnek kellene felváltania, amely növelné a segélyek kiszámíthatóságát is (ami - mint láthattuk a 3.1. táblázatból - a segélyek veszélyei között jelenik meg), átgondolt feltételekhez kellene kötni a támogatás nyújtását és a kötött segélyek arányát vissza kellene szorítani. Mindemellett pedig szükség van a különböző donorok fejlesztési tevékenységének koordinációjára is - ez utóbbit Szent-Iványi (2006) is kiemeli. Marysse és szerzőtársai (2007) mindezt még azzal egészítik ki, hogy figyelembe kellene venni a segélyek regionális hatásait is, és nem kizárólag az adott országban bekövetkezett változásokat kellene értékelni.

\subsubsection{KINEK KELLENE KAPNI A SEGÉLYT?}

Az előző alfejezetekben kifejtettek alapján egyértelműen felmerül a kérdés, hogy mégis mely országokat kellene támogatni, hol lesz valamilyen érdemi eredménye a segélyezési tevékenységnek. Burnside és Dollar (2000), Collier és Dollar (2002), valamint McGillivray és szerzőtársai (2005) amellett érvelnek, hogy a jobb kormányzással rendelkező országokat kellene támogatni, vagy legalábbis a segélyek feltételeként megszabni ilyen jellegű reformokat. Mindezek mellett megjelenik az a nézet is Guillaumont és Chauvet (2001) tanulmányában, hogy a sokkal sérülékenyebb országok hatékonyabban tudják felhasználni a támogatásokat. Ennek ellenére - és ezt a fenti szerzők is többnyire elismerik - a segélyek elosztására egyáltalán nem ez a jellemző.

Ebben a folyamatban nem hagyható figyelmen kívül az, hogy egyes donorországok fejlesztési tevékenységük során talán nem is törekszenek a demokrácia kiépítésére, a jó kormányzás feltételeinek kialakítására, és a szövetség megőrzése érdekében támogatják az adott országot. Például az USA elsősorban a gazdasági (és biztonsági, szövetségesi) érdeket tekinti elsődlegesnek (Todaro és Smith 2009), míg Tuman és szerzőtársai (2009) empirikus elemzése alapján Japán segélyezési kedvét elsősorban a humanitárius célok határozzák meg, semmint a gazdasági érdekek, és nem követi az USA biztonsági érdekei sem. Sőt, kimutatott tény az, hogy a segélyek nagyobbrészt nem is a legrászorultabb (legkevésbé fejlett, illetve alacsony jövedelmü) országokba áramlanak (Glennie 2011). Baulch (2006) tanulmánya alapján például jelentős különbség van a donorok között abból a szempontból, hogy milyen jövedelmi szintü fogadó országokat támogatnak az MDG-ket illetően: míg az Egyesült Királyság és a Világbank az alacsony jövedelmü országoknak juttatja kedvezményes hiteleinek nagyobb részét, addig például az Egyesült Államok és az Európai Bizottság a közepes jövedelmü országokra fókuszál. Ezeket akár tipikus donor magatartásnak 
gondolhatjuk, hiszen a segélyek elsősorban azokba az államokba irányulnak, ahol azt nagyobb biztonsággal tudják felhasználni (Todaro és Smith 2009). Ezzel pedig a leginkább rászoruló országok szorulnak ki a célok megvalósulásából.

Viszont vannak olyan vélekedések is, mely szerint ez korántsem tekinthető problémának, és a közepes jövedelmü országok támogatása nemzeti, regionális és globális (pozitív) következményekkel jár (Glennie 2011). A nemzeti okok szerint ugyanis, ha a közepes jövedelmü országokban él a világ szegényeinek háromnegyede (Summer 2010), valamint ha a fejlesztési politika célja a szegénység csökkentése, akkor ezeket az országokat is támogatni kell (Glennie 2011, Kanbur 2010). Emellett a közepes jövedelmü országokból induló spillover hatások határon átívelőek lehetnek, így az ország közvetlen régiójára is jó hatással lehet a segélyezés (Glennie 2011), valamint a közepes jövedelmü országok segélyezésével olyan tapasztalatok nyerhetők (tudástranszfer), melyekkel akár a legkevésbé fejlett országok segélyezése is hatékonyabbá válhat (Kanbur 2010). Globális ok pedig az, hogy ezen országok támogatásával a globális közjavak eléréséhez (például szén-dioxid kibocsátásának csökkenése, globális béke megteremtése, biztonsági és migrációs kérdések, szegénység csökkenése) járulnak hozzá ${ }^{44}$ (Glennie 2011, Kanbur 2001). Ezzel kapcsolatban empirikus vizsgálatunk során merülhetnek fel kérdések, így érdemes ezt a tényezőt is figyelembe venni.

Mindezek arra utalnak, hogy korántsem megoldott, eldöntött még az a kérdés, hogy a segélyek milyen esetben, mely országokban müködnek hatékonyan, és hogy kitől lehetne tanulni. Az azonban világosan körvonalazódik, hogy az intézményi háttérnek egyre kiemeltebb szerepet tulajdonítanak. Ugyanis a 3.1.3. fejezetben ismertetett tényezők mind az intézményi háttér fejletlenségét elemezték. Ebből kifolyólag ezeket a segélyek hatékonyságának vizsgálata során figyelembe kell venni.

Ugyanakkor napjainkban a világgazdaság és a világgazdasági folyamatok olyannyira átalakultak, hogy az ún. hagyományos fejlesztési segélyezés már nem lehet önmagában elegendő a hosszú távú gazdasági fejlődés elérésében. Emellett a nemzetközi segélyezés hatékonysága megkérdőjelezhető, és nem teljesen egyértelmü, hogy milyen körülmények között müködik hatékonyan (az intézményi hátteret leszámítva, bár nem pontos, hogy milyen intézményekröl beszélünk). ${ }^{45}$ Szentes (2011) alapján utaltunk már arra, hogy a fejlesztési

\footnotetext{
${ }^{44}$ Globális közjavak esetén a fogyasztásából eredő haszon globális szinten érezhető (Horváthné 2010). A globális közjavakról részletes elemzést ad például Kanbur (2001), vagy Horváthné (2010).

${ }^{45}$ Ahogyan Barack Obama is fogalmazott (Elliott 2011. 1. o.): „, a segély önmagában nem lehet fejlesztés. A fejlesztés azt jelenti, hogy segítünk az államoknak valóban fejlödni.",
} 
politika csak akkor lehet sikeres, ha a gazdasági fejlődés előtt álló, országon belüli és országon kívüli akadályok felszámolására is törekszenek. Az elmúlt néhány évben - talán mindezek hatására is - új tendencia jelent meg: a nemzetközi (fejlesztési) szervezetek a nemzetközi kereskedelemben való részvételnek tulajdonítanak (megint) kiemelt jelentőséget, viszont nem kizárólag az elmaradottságra ható nemzetközi tényezők között megjelent aszimmetrikus kereskedelmi kapcsolatok kisimítására törekszenek, hanem már-már kizárólagos fejlesztési eszközként tekintenek rá.

Ennek következtében érdemes ezt a kérdést mélyebben megvizsgálni. A következő fejezetben a nemzetközi kereskedelem és gazdasági növekedés kapcsolatát elemző irodalmat tekintjük át, hiszen a dolgozat központi kérdése a kereskedelempolitikai eszközök eredményességének értékelése, melyet elsősorban a kereskedelmi hatásokon keresztül lehet megtenni. Továbbá bemutatjuk, hogy mely nemzetközi szervezeteknél milyen módon jelenik meg a nemzetközi kereskedelem mint a fejlődést elősegítő gazdasági tevékenység koncepciója. Ezek az empirikus vizsgálatunkhoz nyújtanak elengedhetetlen segítséget, hiszen mind a mutatók, mind a vizsgálati módszerek támpontot jelentenek elemzésünkhöz.

\subsection{A NEMZETKÖZI KERESKEDELEM SZEREPÉNEK MEGJELENÉSE A GAZDASÁGI FEJLŐDÉSBEN}

Az elmúlt néhány évben a nemzetközi kereskedelem szerepe a gazdasági fejlődésben újra felértékelődött, ezzel pedig az exportorientált fejlődésre helyeződik a hangsúly. Bár a 2008-as globális válság a fejlődő országokat is mélyen érintette ${ }^{46}$ (elsősorban a reálgazdaságon keresztül), Hoekman és Wilson (2010) úgy találják, hogy a nemzetközi kereskedelem révén a szegény országok is kilábalhatnak a kedvezőtlen gazdasági visszaesésből, ezért a kereskedelmi lehetőségek fejlesztésére fókuszáló támogatásokat ${ }^{47}$ preferálják. Emellett nem szabad elfelejteni azt, hogy a versenyképességi elemzések is egy ország, régió versenyképességét nemzetközi viszonyok között, a külgazdasági teljesítmény

figyelembe vételével értelmezik (Lukovics 2008). Mindezzel pedig igazolódik az, hogy a nemzetközi kereskedelem szerepe ma már kiemelten fontos.

\footnotetext{
${ }^{46}$ A fejlődő országok helyzete a jelen gazdasági válságban nem tartozik szorosan jelen értekezés témájához, kizárólag a szükséges mélységben térünk ki rá. A téma mélyebb elemzése például Allen és Giovannetti (2011), Griffith-Jones és Ocampo (2009), Phan (2010) vagy Ziesemer (2010) tanulmányában található.

${ }^{47}$ Lásd az Aid for Trade programot a dolgozat 3.3. fejezetében.
} 
Ugyan napjaink gazdasági környezete megköveteli a nyitottságot, azonban már az 1960-as években, a lúdraj ${ }^{48}$ modellel kapcsolatban - és a világrendszer-szemlélettel összhangban - említette Akamatsu Kaname, a modell leírója, hogy az országok fejlődését nem lehet elkülönülten vizsgálni, hanem figyelembe kell venni az országok közötti kapcsolatokat is (Ozawa 2001, 2005). A lúdraj-modellnek többféle változata létezik, ahol az első kettő az országon belüli növekedést, míg a harmadik változata egy térségben a kereskedelem és a tőkeáramlás következtében fellépő, az országok közötti fejlődés terjedését vizsgálja (Kojima 2000, Ozawa 2005). A modell szerint a vezérliba fokozatosan elveszíti komparatív előnyét a munkaerő-intenzív ágazatban, ezért azt kitelepíti az ún. második vonalban lévő országok valamelyikébe, majd technológia-intenzívebb termékek termelésébe, később pedig exportjába kezd - azonban ez a folyamat lejátszódik a második és a harmadik vonalban lévő országok között is (Bhalla és Qui 2004, Dowling és Cheang 2000, Kojima 2000). Ugyan a modell alapja egy valós területi fejlődés: Japán és a kelet-ázsiai térség példátlan elöretörése jelenti a hátteret (Bhalla és Qui 2004, Dowling és Cheang 2000, Furuoka 2005, Kojima 2000, Ozawa 2005), és így érdekes következtetéseket vonhatnánk le, azonban a dolgozat további fejtegetéseiből mégis mellőzzük a modell mélyebb bemutatását. Ennek oka, hogy bár a lúdraj modellben is megjelennek a kereskedelmi elemek, azonban ez esetben a tőkeáramlásnak és a termelés kihelyezésének jelentősebb szerepe van: inkább ezek a tényezők járulnak hozzá a gazdasági fejlődéshez.

Hangsúlyozandó, hogy a nemzetközi kereskedelem gazdasági növekedésben és fejlödésben betöltött szerepe nem új jelenség, hiszen már Adam Smith is arra a végkövetkeztetésre jutott, hogy a nemzetközi kereskedelemben való részvétel növeli a gazdasági teljesítményt, külföldi technológiához lehet hozzájutni, és ezek valamint a növekvő verseny miatt a termelékenység is javul (Irwin 2003). Továbbá, korábban is megjelentek a különböző exportösztönző stratégiák (lásd például a kistigrisek páratlan fejlődését, vagy Kína töretlen elöretörését), illetve - az iparosodást segítendő - az importhelyettesítő politika is sokáig jelentős szerepet játszott. A következőkben így ezen elméleti megközelítéseket is áttekintjük, hiszen ezek célja is a gazdasági fejlődés elérése volt különböző kereskedelempolitikai eszközök alkalmazásával. A nemzetközi szakosodás mögötti tényezőkkel viszont nem foglalkozunk (mint például a komparatív előnyök elmélete, HOmodell, stb). Ezután a nemzetközi kereskedelem és a gazdasági fejlődés kapcsolatát taglaló

\footnotetext{
${ }^{48}$ A modell neve nem egységes a szakirodalomban. Az angol elnevezése a flying geese, melyet Mészáros (2008) repülő vadliba modell néven használja, de például Balatoni és Törös (2010) tanulmányukban lúdraj modellként emlegetik.
} 
empirikus irodalmat tekintjük át. Végül a legfontosabb nemzetközi szervezetek hozzáállását részletezzük.

\subsubsection{AZ IMPORTHELYETTESÍTÉS ÉS KORLÁTAI}

A gazdasági fejlődésről, elmaradottságról alkotott nézetek jelentős mértékben befolyásolták az adott ország viszonyulását a liberálisabb, illetve a protekcionista kereskedelempolitika irányába (Grabowski 1994). A két véglet az állami beavatkozás és a kereskedelem szerepét illetően az importhelyettesítés és az exportösztönzés (Krugman és Obstfeld 2003), ahol az elöbbinél komoly kormányzati beavatkozással különféle kereskedelempolitikai eszközöket vetnek be, míg az utóbbinál a kormányzati beavatkozás némileg - de nem teljes mértékig! - elhanyagolható (Jayanthakumaran 2000). Azonban mindkettő célja, hogy az adott országban az iparosodás magasabb szintjét érjék el komparatív előnyök megteremtése, illetve kihasználása által. Viszont az importhelyettesítés nagyon gyakran a komparatív előnyök ellen megy, és olyan iparágak megteremtését célozza, amelyek esetében komparatív előnyről nem lehet beszélni (erre a későbbiekben még kitérünk). Emellett fontos hangsúlyozni, hogy ugyan gazdaságpolitikai választásról van szó, a két politikára egymás kiegészítőjeként szükséges tekinteni: az exportösztönzést általában importhelyettesítés előzi meg.

Az importhelyettesítés stratégiájának nincs egységes definíciója (Bruton 1968), azonban általánosan elfogadott, hogy importhelyettesítés során az ország az importot jelentős mértékben korlátozza különféle (tarifális és nem tarifális) kereskedelempolitikai eszközökkel (és esetleg árfolyam-politikával ${ }^{49}$ ) (Grabowski 1994, Jayanthakumaran 2000, Levy-Orlik 2009, Rodrigues 2010, Subasat 2009). A korlátozott import célja egyrészt a belföldi piacra termelő feldolgozóipar fejlődésének biztosítása, valamint a kiskorú iparágak védelme $e^{50}$ azáltal, hogy a külső versenynek nincs kitéve, másrészt pedig az iparcikkek importjának korlátozásával a hazai ipar (nemzetközi szinten is) versenyképessé tétele (Grabowski 1994, Jayanthakumaran 2000, Krugman és Obstfeld 2003, Levy-Orlik 2009, Rodrigues 2010, Subasat 2009). Összességében ezt importhelyettesítő iparosítási stratégiának nevezzük (Krugman és Obstfeld 2003). Az importhelyettesítés hátterében áll az is, hogy a fejlődő országok nem fogadják el azt az állítást, miszerint a kereskedelem a

\footnotetext{
49 Felülértékelt árfolyammal a tőkejavak importját teszik olcsóbbá, melyek az iparosodáshoz szükségesek (Grabowski 1994).

${ }^{50}$ A növendék-iparág koncepciója $F$. List nevéhez köthető, és számos fejlődő ország alkalmazta a hatvanashetvenes években (Csáki 2002).
} 
növekedés motorja (ahogy a fejlődés-gazdaságtan függőségi iskolájának képviselöi hangsúlyozzák), és inkább a befelé forduló (inward-looking) iparosodási politikát tekintik követendő célnak (Bruton 1968). Az iparosodás elindulását pedig a learning by doing tanulási folyamat érvényesülésében látják (Shaffaedin és Pizarro 2007).

Az importhelyettesítés logikája már az 1929-1932 közötti válság idején megjelent, ugyanis akkor a nyersanyagok ára 50 százalékkal csökkent, és bár az iparcikkek árai is estek, a kevésbé fejlett országok mégis jelentős cserearány-romlást szenvedtek el. Valamint a második világháború idején ugyan jelentős exportbevételre tettek szert a nyersanyagok exportja révén, viszont iparcikkeket, termelő berendezéseket a háborús helyzet miatt nem tudtak importálni, ami pedig az iparosodási lehetőségeiket jelentős mértékben korlátozta. Mindezek miatt egyre több ország kezdte az importhelyettesítés politikáját alkalmazni (Södersten 1985). Majd a függőségi irányzat (marxista, újbaloldali) képviselői érveltek amellett, hogy importhelyettesítő politikával érhető el a gazdasági fejlődés a centrum országainak kizsákmányoló magatartása, illetve annak elkerülése miatt (Gilpin 2006, Paragi et al 2007, Sutcliffe 2008, Szentes 2011, Világbank 1991). Ezzel elterjedt az az exportpesszimista (export pessimism) - nézet, hogy ha a fejlődő országok csak primer termékeket exportálnak, akkor a szabad kereskedelem csak ezt a szerepüket erősíti tovább, és nem fogja az iparosodásukat segíteni, így elmaradottságuk a szabad kereskedelem következtében konzerválódik (Irwin 2003). Ezek eredményeként ez a gazdaság- (és kereskedelem-) politika az 1950-60-as években élte virágkorát Latin-Amerikában, és egészen az 1980-as évekig az országok többsége fejlesztési stratégiájukban a kereskedelmet korlátozó politikát tekintette elsődlegesnek (Rodrigues 2010).

Összességében nem tekinthető sikeresnek a politika alkalmazása. Latin-Amerika országainak relatív elmaradottsági szintje nem változott lényegesen (Levy-Orlik 2009, Palma 2008b): nemcsak a relatív jövedelmi helyzetük maradt lényegében változatlan, hanem a technológiai színvonaluk is jóval elmaradottabb volt (Rodrigues 2010), azaz a learning by doing mint tanulási mód nem volt sikeres. Az importhelyettesítő gazdaságpolitikát folytató fejlődő országok zöme nem tudott a fejlett országokhoz felzárkózni, és az importhelyettesítő politika korlátait az alábbiakban látták (Grabowski 1994, Jayanthakumaran 2000, Krugman és Obstfeld 2003, Levy-Orlik 2009, Palma 2008b, Södersten 1985):

- az állami beavatkozás (egyrészről korlátozás, másrészről támogatás) az egész gazdaság számára jelentős mértékü közvetlen (források rossz elosztása, fogyasztói 
jólét csökkenése) és közvetett költséggel (nem termelékeny tevékenységek védelme) jár;

- az iparvédelmi időszak nem teremt automatikusan hatékony és versenyképes feldolgozóipart, melynek oka a szakképzett munkaerő, vállalkozói és vezetői ismeretek hiánya, valamint az alacsony fokú társadalmi szervezettség;

- az iparfejlesztés ösztönzésének költsége magas, ami gyakran nem egyértelmü támogatási-védelmi rendszerrel párosul;

- a védelem miatt olyan iparágak is fennmaradtak, melyek költségesebben müködtek, mint azon import ára, amit helyettesítettek (azaz nem a komparatív előnyök szerinti szakosodás alapjait teremtették meg);

- a védelem következtében a kisméretü és alacsony hatékonyságú termelés virágzott, akár monopoltermelés is kialakulhatott a kisméretü belföldi piacokon;

- az ipari termelés olyan termékek gyártására koncentrálódott, melyeket kizárólag az elitréteg fogyasztott;

- az importhelyettesítő gazdaságpolitika szerepet játszott a duális gazdaság kialakulásában és megerősödésében, hiszen nem volt tovagyürűző hatása (elsősorban a hagyományos szektorra);

- az importhelyettesítés gyakran mellőzte a mezőgazdaság fejlesztését, ennek következtében más - társadalmi - problémákat súlyosbított, például nőtt a jövedelemegyenlőtlenség vagy a munkanélküliség, illetve a mezőgazdaságból élők relatíve alacsony jövedelmi szintje miatt az iparcikkek piaca is szükült.

Az 1980-as évekre széles körben - a fejlődő országok és a nemzetközi szervezetek körében egyaránt - elfogadottá vált, hogy az importhelyettesítés nem a legmegfelelőbb stratégia a gazdasági fejlődés elérésében, és inkább a viszonylag nyitottabb - kifelé tekintő (outward-oriented) - gazdaságpolitika folytatása nyert teret (Grabowski 1994, Jayanthakumaran 2000).

\subsubsection{AZ EXPORTÖSZTÖNZÉS MINT GAZDASÁGFEJLESZTÉSI ESZKÖZ}

Az exportösztönzés elfogadottságának oka elsődlegesen néhány ázsiai ország fejlődésének sikere, bár ez a fejlődés nem tulajdonítható kizárólagosan a szabad kereskedelemnek (Krugman és Obstfeld 2003). Az exportorientációt támogatók általában azzal érvelnek, hogy a szabad kereskedelem lehetővé teszi a tudás és a technológia áramlását, ezáltal a nemzetközi kereskedelemben való részvétel egyértelműen előnyös az adott ország 
gazdasági fejlődése szempontjából: a tanulás a munkamegosztáson keresztül történik (learning through trading) (Shaffaedin és Pizarro 2007). A neoliberálisok egyértelmüen a szabad kereskedelem mellett foglalnak állást, és az importhelyettesítő politikát a fejlődés gátjának tartják (Jilberto és Mommen 2003).

Az exportösztönzés azonban nem kizárólag annyit jelent, hogy az export előtt álló akadályokat eltöröljük, hanem azon állami beavatkozásokat is ide kell sorolni, melyek az export volumenének növelésére irányulnak (Laux-Meiselbach 1989). Bár a kormányzati beavatkozást többnyire nem támogatják a nemzetközi kereskedelmi folyamatokban, és ma már a GATT/WTO szabályrendszere lényegében nem is engedi ezt (elsősorban az exporttámogatásokról van szó) (Krugman és Obstfeld 2003, Yin és Yin 2005), számos fejlődő ország nyúl hozzá olyan eszközökhöz (valutaleértékelés, exporttámogatások, alacsony kamatozású hitelek, tengerentúli megjelenés támogatása, stb.), melyekkel az exportot ösztönzik (Yin és Yin 2005). ${ }^{51}$

Az exportösztönzés lehetséges gazdasági fejlödésre gyakorolt hatásait többen elemezték. Például Yin és Yin (2005) elméleti oldalról közelítették meg, hogy a fejlődő országok vajon mennyit nyerhetnek az exportösztönzésből, növeli-e a termelést és a foglalkoztatottságot, valamint hozzájárul-e a hatékonyság és a társadalmi jólét növekedéséhez. A szerzők abból indulnak ki, hogy az adott fejlődő ország felismeri, hogy a további gazdasági fejlődéséhez a termelékenység és a technológia színvonalának javítására van szükség, viszont a korlátozott kutatás-fejlesztési kiadások miatt az új technológiát importálnia kell. Ugyanakkor a kiegyensúlyozott fizetési mérleg fenntartása miatt exportálnia is szükséges, viszont az egyensúly fenntartása akadályokba ütközhet, ha az ország nem tud annyit exportálni, amennyit kellene, vagy ha fix árfolyamrendszert tart fenn. Továbbá előfordulhat az is, hogy a hazai cégek nem képesek vagy nem hajlandók az új technológiába befektetni. Ennek következtében a kormánynak exporttámogatásokkal közbe kell lépnie, melynek hatására megélénkül az export és az új technológiába való invesztálás is. A szerzők modelljük kidolgozása után arra a következtetésre jutnak, hogy általános egyensúlyi modellben a fejlődő országok számára az exportösztönzésnek olyan fajtái, mint az exporttámogatás és a valuta-leértékelés pozitív hatásokkal járnak: modernizálódik a technológia, javul a foglalkoztatás és a termelékenység. Viszont a nem exportra szakosodott cégek és a hazai árszínvonal számos más tényezőtől függ, úgy, mint a háztartások preferenciái, illetve a termelési függvény alakja. A szerzők úgy vélik, hogy sikeres

\footnotetext{
${ }^{51}$ A fejlődőek mellett a fejlett országok is élnek ezekkel a lehetőségekkel, ami miatt számos kritika is éri őket.
} 
exportösztönzés érdekében a termelékenység növekedése kiemelten fontos. Tehát a szerzők szerint az exportorientált cégek egyértelmủen nyernek az exportösztönző politika során, míg a hazai fogyasztásra termelö vállalatok esetében több tényezőt kell figyelembe venni. Ezt továbbgondolva összességében az ország fejlődésére gyakorolt hatások e kettő összegeként adódik, így nem feltétlenül lesz pozitív a mérleg.

Vos és szerzőtársai (2004) már az elméleti megközelítésen túl arra keresték a választ, hogy a latin-amerikai országokban az 1980-as években bekövetkezett liberalizálási reformok és az exportvezérelt gazdasági növekedés hozzájárultak-e a gazdasági növekedés lassulásához, illetve volt-e valamilyen szerepe a jövedelemegyenlőtlenség növekedésében. Azaz a szerzők az exportorientált politika lehetséges negatív következményeit próbálták feltárni. Modelljük szerint a liberalizálás a gazdasági növekedéshez és a szegénység csökkentéséhez pozitívan járult hozzá. Ugyanakkor a jövedelemegyenlőtlenség növekedése is tapasztalható, hiszen elsősorban a magasabban képzettek lettek a kereskedelmi reformok nyertesei, viszont ezt némileg kompenzálja a növekvő foglalkoztatás. Eredményeik szerint az export támogatása hasonlóan kedvező hatású: a foglalkoztatás növekedése mellett a szegénység is csökken. Végső konklúziójukban azonban óvatosabban fogalmaznak: az exportvezérelt növekedés nem tekinthető a jólétnövekedés csodaszerének, viszont nem is tekinthető a bajok okozójának.

Ezek alapján az exportösztönző stratégia sem feltétlenül jelenti a gazdasági fejlődés biztos alapját, habár több eredménnyel járhat, mint az importhelyettesítés. Ezt a vonalat azért is érdemes tovább vizsgálni, hiszen a nemzetközi környezet - elsősorban a nemzetközi szervezetek - mégis egyre inkább rákényszerítik az országokat - a fejlődőeket is kereskedelmük liberalizálására (Stiglitz, 2003), azaz inkább kifelé tekintő gazdaságpolitika folytatására „ösztönzik” az országokat. Mindez pedig egyre inkább a neokolonizáció felé tereli a kérdést: a régi gyarmattartók és a mai nagyobb hatalmak így akarnak befolyást szerezni, így akarják befolyásukat megőrizni a fejlődő országok (volt gyarmatok) felett? Viszont az exportösztönzés kormányzati beavatkozásának meglehetősen szük teret adnak. Grabowski (1994) általánosságban, Esu és Awara (2010) Nigériát elemezve számos tényezőre felhívják a figyelmet, melyek e folyamat hátrányai lehetnek:

- Nigéria olajfüggő, így kevesebbet nyert a liberalizálási folyamatokból, mint a nagyobb kereskedelmi partnerei;

- a kereskedelmi liberalizáció jelentősen megnövelte az importhajlandóságot, viszont az export folyamatosan csökkent, különösen a nem-olaj ágazatokban; 
- nincs egyértelmű kapcsolat a kereskedelmi liberalizáció és fejlődés között;

- ha néhány fejlődő ország exportorientált stratégiát követ, akkor a fejlett országok piaca jelentős nyomás alá kerül, melynek következtében különböző kereskedelmi akadályokat vethetnek ki;

- a fejlett országok vám és nem vámjellegü kereskedelempolitikai eszközei jelentős mértékben akadályozzák a fejlődő országok exportját;

- a Textil és Ruházati Egyezmény ${ }^{52}$ végrehajtása a fejlett országokban nem teljesen elfogadható a fejlődő országokban;

- számos fejlődő országra még jellemző a gyarmati típusú nemzetközi munkamegosztás, illetve kedvezőtlen alkupozíciójuk miatt az északi államok, illetve multinacionális vállalatok érdekeit kénytelenek követni;

- a nyersanyagok árának csökkenése (ingadozása) az ipari termékekhez képest jelentős mértékben kihat azon fejlődő országok fejlődésére, melyek a nyersanyagokból származó bevételektől függnek (cserearány romlása);

- a fejlett országokban a (bio)technológia fejlődésével párhuzamosan csökkent a fejlődő országokból származó mezőgazdasági termékek kereslete, így azok árának esése cserearány-romláshoz vezetett.

E tényezőkből látható, hogy az egy termékre vagy egy-két nyersanyag exportjára szakosodó gazdaságok és a fejlődő országok többsége nagy valószínüséggel nem tud élni a globalizáció adta lehetőségekkel. Ezért elengedhetetlen az iparosítás. De ezt hogyan lehet elérni, ha az importhelyettesítés sem megfelelö, és az exportösztönzésnek is megvan a maga hátránya? Egy ország folytathat-e egyszerre importhelyettesítést és exportösztönzést? Vagy e két stratégiára egymás kiegészítőjeként kell tekintünk? Alapvetően importhelyettesítő és exportösztönző stratégia nem lehet egy időben, ugyanis semlegesíthetik egymást (Subasat 2009), hiszen az iparágak védelme erőforrásokat von el az exportra képes iparágaktól (Krugman és Obstfeld 2003), és összességében óriási költséggel jár: mind a védelem (import), mind a támogatás (export) komoly kormányzati kiadásokat igényel. Ezzel ellentétben Hout (1996) amellett érvel, hogy az exportösztönzés és az importhelyettesítés lehet egy időben, és nem fogják semlegesíteni egymást, ahogyan azt néhány kutató feltételezi. Empirikus úton is elemezte állításait, és 84 ország bevonásával elvégzett vizsgálata alapján az országok egy

\footnotetext{
52 2005. január 1-jéig - az Uruguayi Fordulón elfogadott egyezmény alapján - a textiltermékekre vonatkozó összes kvótát meg kellett szüntetni a fejlődő országokból származó importra vonatkozóan (Andriamananjara et al 2006).
} 
időben tudnak importhelyettesítő és exportösztönző elemeket alkalmazni. Ugyanakkor a szerző azt is elismeri, hogy az importhelyettesítés és az exportösztönzés a gazdasági növekedésre ellentétes irányban hat. Ezek miatt óvatosan kell kezelni ezt az eredményt, nem feledve a két stratégia költségeit sem.

A kérdés másik részét illetően - azaz, hogy a két politika egymás után következhet-e, és erősítheti-e egymást - az állítható, hogy az importhelyettesítés és az exportösztönzés gyakran követi egymást és egymás kiegészítőjeként lehet rájuk tekinteni (Subasat 2009, Todaro és Smith 2009). Shaffaedin és Pizarro (2007) e folyamat sikerességét elemezte Kína és Mexikó vonatkozásában, hiszen mindkét ország erős importhelyettesítő politika után tért át exportösztönző kereskedelempolitikára. A tanulmány eredményei szerint mindkét ország jól járt az importhelyettesítő politikával, hiszen mindketten ki tudtak fejleszteni komparatív előnyökre épülő ipart, viszont az exportorientáció időszakában Kína nagyobb mértékben tudta növelni az exportorientált iparok hozzáadott értékét - ez azonban nagyban köszönhető a külföldi tőke beáramlásának is. Ennek értékelése során figyelembe kell venni azt is, hogy ma már a nemzetközi környezet a nemzetközi munkamegosztásban való részvételre kényszeríti az országokat, és egyre kevesebb lehetőség marad az importhelyettesítő gazdaságpolitikának, és az exportösztönzés lehetőségei is korlátozottak. Ugyanakkor a nemzetközi kereskedelemben való részvétel ösztönzésére, helyzetükből adódó hátrányok leküzdésére a fejlődő országok különböző kereskedelmi preferenciákban részesülnek, amit akár exportösztönzésnek is fel lehet fogni, csak ez „kívülről” érkezik, viszont a kedvezményt nyújtó országok gazdasági érdekei is jelentősen befolyásolják.

Napjainkra a kereskedelmi nyitottság fontos tényező lett a gazdasági fejlődésben. Ugyan az elmúlt évtizedekben a kereskedelmi nyitottság és annak hatásai a kutatások középpontjába került, az empirikus szakirodalom alapján a kereskedelmi nyitottság és a gazdasági növekedés (fejlődés) közötti kapcsolat nem egyértelmü. A következőkben ezeket az irodalmakat és eredményeket tekintjük át a vitás pontok alapján.

\subsubsection{A NEMZETKÖZI KERESKEDELEM GAZDASÁGI FEJLŐDÉSBEN BETÖLTÖTT SZEREPE}

A korábbi felfogás, miszerint a kereskedelem a gazdasági növekedés motorja (Ekholm és Södersten 2002, Freund és Bolaky 2008), ma már kibővült azzal, hogy a fejlődés és a szegénység csökkentésének egyik eszköze lehet (Dollar és Kraay 2003, Hallaert és Munro 2009, UNCTAD 2005b). Winters és szerzőtársai (2004) ez utóbbi állítást némileg finomítják, és irodalmi áttekintésük alapján úgy vélik, hogy a kereskedelmi liberalizáció - 
ugyan nem a leghatékonyabb eszköz, de - a szegénységcsökkentési fejlesztési stratégiák költségtakarékos része lehet (Winters et al 2004), azaz nem lehet kizárólagos fejlesztési eszközként tekinteni a nemzetközi kereskedelemben való részvételre. Viszont ez a folyamat nagyon könnyen belátható: a jövedelem növekedése jelenti a fejlődés alapját, ami pedig a kereskedelem, beruházások, valamint a termelési lehetőségek bővülésén keresztül érhető el (Helble et al 2009).

Ennek ellenére a mai napig vitás kérdés, hogy milyen kapcsolat van a nemzetközi kereskedelemben való részvétel, a kereskedelmi nyitottság és a gazdasági növekedés között. A lehetséges kapcsolatot már többen, többféle módon tesztelték az elmúlt évtizedekben, azonban nincs egységes álláspont a hatásokat illetően (Baldwin 2003, Moreira 2010, Subasat 2002). Bár a neoklasszikus felfogás egyértelmủen a nemzetközi kereskedelem liberalizálása, az exportösztönzés mellett foglal állást, és a közgazdasági főáramlat szerint az exportbővítés hozzájárul a gazdasági növekedéshez és fejlődéshez, máig vitatott, hogy az exportorientáltság milyen mértékben járul hozzá az ország gazdasági teljesítményéhez (Hoekman és Özden 2005, Lee 2005, Subasat 2002). Stiglitz és Charlton (2006) hangsúlyozzák, hogy bizonyos tényezők miatt a nemzetközi kereskedelem csak és kizárólag szükséges, de nem elégséges feltétele a fejlődésnek.

A kapcsolódó irodalom feldolgozása az általunk fontosnak ítélt vitapontok bemutatása alapján történik, ezzel is rámutatva egyrészt arra, hogy milyen feltételek között lehet a kereskedelmi nyitottságnak pozitív hatása a gazdasági növekedésre, fejlődésre. Másrészt pedig információt nyerünk arra vonatkozóan, hogy a kereskedelmi hatások elemzésére épülő empirikus vizsgálatunk során milyen tényezőket szükséges figyelembe venni. Az irodalmi áttekintés során az alábbi kérdéses pontok merültek fel, és ennek alapján ismertetjük a szakirodalmat:

- milyen jövedelmi szintü országok nyernek;

- a költségvetési hiány hogyan alakul;

- van-e valódi kapcsolat a gazdasági növekedés és a kereskedelmi nyitottság között;

- az endogenitás nem torzítja-e az eredményeket;

- a kereskedelmi kedvezményeknek milyen hatásai vannak. 


\section{A jövedelmi szint befolyásolja-e a kereskedelmi nyitottságból eredő hasznokat?}

Balassa (1985) vizsgálatában arra jutott, hogy azok a fejlődő országok (jövedelmi szinttől függetlenül), amelyek az olajárrobbanás okozta válság idején nyitott és exportösztönző gazdaságpolitikát folytattak, gazdasági növekedést tudtak elérni. Továbbá, azok az országok, melyek aktívan részt vesznek a nemzetközi kereskedelemben, sokkal ellenállóbbak a külső sokkokkal szemben, mint azok, amelyek befelé forduló stratégiát követnek. Viszont a tanulmányból nem világos, hogy ezek az országok azért nyitottak-e, mert egyébként is ellenállóbbak, azaz nem egyértelmü az ok-okozati kapcsolat. Azonban hasonlóan vélekednek Sentsho (2003), valamint Wilbur és Haque (1992) is: fejlett és fejlődő országokra egyaránt kiterjedő empirikus elemzésük alapján az exportvezérelt gazdasági növekedés a fejlett és a fejlődő országok számára egyaránt hordoz magában előnyöket. Továbbá Yanikkaya (2003) elemzése arra is rámutat, hogy a kereskedelem növekedésre gyakorolt hatása nem mutat jelentős különbséget, ha a kereskedelem során az ország partnere fejlődő vagy fejlett állam.

Viszont Meschi és Vivarelli (2009) empirikus úton bizonyítják, hogy a magas jövedelmű országokkal való kereskedelem növeli a jövedelemegyenlőtlenséget a fejlődő országon belül, melynek oka elsősorban a technológiai különbségekben keresendő. A kedvezőtlen jövedelemelosztás mélyülése pedig a gazdasági növekedésre negatívan hat. Dobson és Ramlogan (2009) szintén a nyitottság és a jövedelemegyenlőtlenség közötti kapcsolatot elemezték kizárólag latin-amerikai országok vonatkozásában, a szerint, hogy létezik-e fordított U-alakú (Kuznets) görbe a nyitottság vonatkozásában is. Azaz a nyitottság növekedése egy bizonyos szintig növeli-e az egyenlőtlenséget, és utána csökken-e. A szerzők eredményei szerint Latin-Amerikában a Kuznets-hipotézis elfogadható a kereskedelmi nyitottság és az egyenlőtlenség kapcsolatát illetően. A szerzők viszont hangsúlyozzák azt, ami jogosan felmerülhet a vizsgált minta ismerete alapján: az eredményt nem lehet általánosnak tekinteni sem a fejlődő, sem fejlett országok vonatkozásában, ez kizárólag a latin-amerikai régió esetében áll fenn.

Számos szerző (Dodaro 1991, Subasat 2002, Yaghmaian 1994) viszont arra jutott elemzése során, hogy az exportösztönző stratégia sikerességét az ország fejlettségi szintje jelentős mértékben befolyásolja, és a közepes jövedelmü országok lehetnek a nyertesek. Freund és Bolaky (2008) ugyan nem a jövedelmi helyzet között tett különbséget, hanem a rugalmas és a merev szabályozási háttérrel rendelkező államok között (azaz az intézmények szerepét is vizsgálták): eredményeik szerint a kereskedelem gazdaságélénkítő hatása a 
rugalmas államokban jelenik meg, míg a merev országokban ez nem jellemző. Ezek alapján kutatásunk során az országok jövedelmi helyzetét is figyelembe kell majd vennünk.

\section{Milyen következményei lehetnek a kereskedelmi nyitottságnak a költségvetési} hiányra? Ugyan a költségvetés egyenlegére számos tényező hat, mégis vannak olyan tanulmányok, amelyek a liberalizáció következtében csökkenő vámok hatásait elemezték. Ennek relevanciája talán az lehet, hogy számos olyan fejlődő ország van, melyek jelentős mértékben függnek a vámoktól, egyes karibi országokban akár a kormányzati bevételek egynegyedét is elérheti a vámokból származó bevételek nagysága (Moreira 2010). Ennek ismeretében a vámok csökkenése jelentősen növelheti a költségvetési hiányt, amit nem feltétlenül tudnak ellensúlyozni például az adók növelésével a gyenge pénzügyi rendszer és az adóbeszedés nehézségei miatt (Todaro és Smith 2009). Ennek ismeretében érdemes kitérni a költségvetési hiány és a vámcsökkenések közötti kapcsolat vizsgálatára.

Combes és Saadi-Sedik (2006) elemzésükben a kereskedelmi nyitottság hatásait a költségvetési hiányra vonatkozóan elemezték. Vizsgálatukat 66 fejlődő országra vonatkozóan végezték el. Eredményeik szerint minél nyitottabb egy gazdaság, annál jobban kitett a gazdasági sokkoknak (ezzel pedig Balassa (1985) állításával ellentétes eredményre jutottak), ami pedig a cserearány instabilitásának negatív hatásait erősítheti a költségvetési deficit vonatkozásában. Agbeyegbe és szerzőtársai (2006) ugyan a költségvetési hiánnyal való kapcsolat vizsgálatát szükebben értelmezték, azonban más eredményre jutottak. A szerzők a kereskedelmi liberalizáció és az aggregált adóbevételek közötti kapcsolatot vizsgálták feketeafrikai országok tekintetében. Eredményeik szerint nincs erős kapcsolat e két változó között, és ha az ország megfelelő monetáris politikát hajt végre, akkor az adóbevételek nagysága megőrizhető. Ez utóbbi vizsgálat is bizonyítja azt, hogy a nyitottság és a költségvetési hiány közötti kapcsolat vizsgálata nem lehet kizárólagos, más tényezőket is figyelembe kell venni. Ebből kifolyólag empirikus elemzésünk során a költségvetési hiányt mint változót mellőzni fogjuk, és nagyobb hangsúlyt fektetünk a külkereskedelmi mérleg egyenlegének alakulására.

\section{A nemzetközi kereskedelemben való részvétel és a nyitottság valóban} hozzájárul a gazdasági növekedéshez? Yanikkaya (2003) a kereskedelem volumenét tekintve a nyitottság proxy mutatójának arra jutott, hogy a nyitottság és a gazdasági növekedés között pozitív kapcsolat áll fenn. A szerző empirikus vizsgálata során azt állapította meg, hogy a kereskedelmi korlátozások és a gazdasági növekedés között pozitív kapcsolat van, viszont a hatás számos más tényezőtől is függ: fejlett vagy fejlődő országról 
beszélünk-e, kicsi vagy nagy ország, és hogy az adott országnak a védelem alá vont szektorban van-e komparatív előnye. Salahuddin és Islam (2008) eredményei szerint a kereskedelmi nyitottság a fejlődő országokba érkező befektetések alakulására is szignifikáns hatással van, mindezzel pedig a gazdasági növekedést is jótékonyan befolyásolja. Manole és Spatareanu (2010) 131 ország vizsgálatával arra jutottak, hogy a kereskedelmi korlátozások egy százalékos csökkentése 0,3 százalékos növekedést eredményez az egy före jutó GDP-ben.

Ezek mellett egyre több olyan elemzés született, amelyek az intézmények szerepét is vizsgálták. Chang és szerzőtársai (2009), akik szintén gazdasági növekedés-központú vizsgálatot végeztek el, már óvatosabban fogalmaznak: eredményeik szerint a kereskedelem pozitív hatásai sokkal nagyobbak lehetnek a gazdasági növekedést illetően, ha kiegészítő reformokat hajtanak végre (például az oktatás, infrastruktúra és kormányzás terén). Freund és Bolaky (2008) szintén feltételekhez köti az eredményeket: ha az ország szabályozási háttere rugalmas, akkor a kereskedelem egy százalékos növekedése legalább 0,5 százalékos növekedést eredményez az egy före jutó GDP-ben, míg ugyanez a merev szabályokkal rendelkező országokban nem igaz. Eredményeik szerint így a vállalatok belépési lehetőségeit és üzleti környezetét kell fejleszteni a kereskedelmi reformok végrehajtása elött. Az elemzés csak a szabályozási környezet lehetséges hatásaira tért ki, de a vállalatok versenyképességével nem foglalkozott. Nenci és Pietrobelli (2007) latin-amerikai országokat elemeztek, a teljes 20. századot lefedő vizsgálatuk alapján arra a végkövetkeztetésre jutnak, hogy a formalizált vámcsökkentések (akár regionális integrációkon belül, akár a multilaterális kereskedelmi rendszeren keresztül történik) nagyobb hatással van a gazdasági növekedésre. Ezek igazolják azt, amit az előző fejezet végén hangsúlyoztunk: a nemzetközi kereskedelem hatásainak vizsgálata során az intézményi hátteret is figyelembe kell venni.

Haddad és szerzőtársai (2010) már a globális válságok hatásait is elemezték a kereskedelmi nyitottság és a gazdasági növekedés közötti kapcsolat vizsgálata során. Empirikus elemzéssel alátámasztott eredményeik szerint a növekedés ingadozását mérsékelni lehet exportdiverzifikációval (és inkább termék, mint piac tekintetében). Emellett, Dodzin és Vamvakidis (2004) tanulmányában rámutat arra, hogy a növekvő nyitottság - a mezőgazdaság rovására - hozzájárul az ipari hozzáadott érték növekedéséhez, ez pedig a gazdasági fejlődés jelének tekinthető. Ennek alapján az ipar hozzáadott értékére és az export diverzifikációjára is figyelmet kell fordítanunk elemzésünk során.

Hangsúlyozandó, hogy a nemzetközi kereskedelem nem kizárólag exportból áll, viszont az importoldal vizsgálatáról általában elfeledkeznek a kutatók. Karbasi és Tavana 
(2009) tanulmányukban arra hívják fel a figyelmet, hogy nem csak az export rejthet elönyöket a fejlődő országok számára, hiszen az import révén olyan kiegészítő termékekhez, szolgáltatásokhoz, technológiához juthatnak hozzá, amelyek hozzájárulnak a hatékonyabb hazai termelés kialakulásához. Ezek pedig - ha valóban így történik - a fejlődő országok elmaradottságához vezető tényezők között szereplő export- és importkényszer negatív hatásait ellensúlyozhatják. Ugyanakkor a szerzők nem foglalkoztak azzal, hogy a növekvő import akár külkereskedelmi egyensúlytalanságot is okozhat. Erre egyértelmü utalást találhatunk Pacheco-Lopez (2005) tanulmányában. Elemzésében Mexikóra tért ki, és eredményei alapján az 1980-as években lezajlott kereskedelmi reformok ugyan megnövelték az exportot és az importot is, azonban ez utóbbira nagyobb mértékben hatott. Így későbbi empirikus vizsgálatunk során így nem kizárólag az exportot szükséges változóként szerepeltetnünk, hanem az importot is, viszont figyelembe kell vennünk a növekvő import okozta egyensúlytalanságokat is, például a külkereskedelmi mérleg egyenlegének szerepeltetésével.

\section{A kereskedelmi nyitottság és a gazdasági növekedés közötti kapcsolat} vizsgálata során az endogenitás nem torzítja az eredményeket? Annak ellenére, hogy számos empirikus vizsgálatot végeztek már ezen a területen, Subasat (2002) hangsúlyozza, hogy az export és a GDP növekedése közötti kapcsolat vizsgálata nem helyes, hiszen az export a GDP részét képezi, így az autokorreláció ${ }^{53}$ jelentősen torzíthatja az eredményeket. Lee és szerzőtársai (2004) megpróbálták a nyitottság és a növekedés endogenitási problémáját kezelni, melyhez egy új módszert (identification through heteroskedasticity) használtak: a varianciát befolyásoló instrumentális változót vontak be elemzésükbe. Végeredményeik szerint a kereskedelmi nyitottság pozitívan hat a gazdasági növekedésre. Dreger és Herzer (2011) tanulmányukban szintén kezelték az endogenitási problémát, méghozzá egy egyszerü módon: az export volumene és a nem-export alapú GDP közötti kapcsolatot vizsgáltak. Ez utóbbi indikátor pedig egyszerüen a GDP és az áruk és szolgáltatások exportjának különbsége, melynek következtében a szerzők nagyon leegyszerüsítették az elemzést. 45 fejlődő országot bevonva eredményeik szerint a két változó között rövid távon pozitív a kapcsolat, viszont hosszú távon ez negatívvá válik, ugyanakkor a hosszú távú hatások országonként eltérőek. Kontrollváltozók bevonásával általános következtetésük az, hogy a gazdaság diverzifikálása révén visszaszorított primertermék-függőség, a vállalkozások alapítása előtt álló akadályok lebontása, illetve a munkapiac rugalmasabbá tétele biztosíthatja hosszú távon is az exportvezérelt növekedést. Ezzel a szerzőpáros is az intézmények szerepét

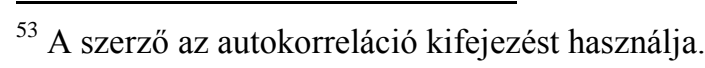


hangsúlyozza, mint ahogy korábban már - többek között - Freund és Bolaky (2008) tanulmányában láttuk.

Rodríguez és Rodrik (1999) azonban tanulmányukban kritizálják azokat a módszereket, amelyeket kereskedelem előtt álló akadályok és a gazdasági növekedés közötti kapcsolat vizsgálatához használnak. A szerzők ezt azzal indokolják, hogy a nyitottság mérésének mutatói gyakran kapcsolatban állnak a rossz gazdasági teljesítményt mérő (jelző) mutatókkal. Végső eredményeik szerint az alacsonyabb vámszint és a nem vámjellegü akadályokkal mért nyitottság csak kis mértékben járul hozzá a gazdasági növekedéshez. Mindezek alapján az endogenitási probléma kezelése után is találtak pozitív kapcsolatot a kereskedelmi nyitottság és a gazdasági növekedés között, így érdemes a továbbiakban is vizsgálni a kérdést. Viszont arra is rávilágítottak arra is, hogy számos tényezőtől függ a kapcsolat megléte, amit többnyire intézményi minőséget jelző mutatókkal közelítettek meg.

5. Milyen hatásai vannak a kereskedelmi kedvezményeknek? Az eddig feltüntetett tanulmányok az exportösztönzést, vámcsökkentést, nyitottságot külső tényezőként vagy a kormány céljaként értelmezték. Azonban a kereskedelmi preferenciák nagymértékben befolyásolhatják e folyamatokat. Ezekre kitérni pedig azért is szükséges, hiszen a dolgozat egyik empirikus vizsgálata az Európai Unióból érkező kereskedelmi preferenciákhoz kötődik. Az elmúlt évtizedekben a fejlett országok több-kevesebb kereskedelmi preferenciát (azaz kedvezményes piacra jutást) biztosítottak a legtöbb fejlődő ország számára (Deadorff és Stern 2009, $N g$ és Yeats 1997), melynek elsődleges célja a kevésbé fejlett országok diverzifikált exportja kialakulásának elősegítése volt (Hoekman 2006). A kereskedelmi preferenciák vizsgálata továbbá azért is fontos, mert a jelenlegi multilaterális kereskedelmi rendszerben a kedvezmények eróziója a jellemző (Deadorff és Stern 2009, Hoekman és Özden 2005). A folyamatosan csökkenő vámszint egyrészt nagyobb versenyt támaszt, másrészt pedig a fejlődő országok vámbevételeinek csökkenéséhez vezet, holott a vámbevételek egyes országokban komoly kormányzati forrásnak minősülnek (Moreira 2010). A negatív kép ellenére Özden és Reinhardt (2005) arra jutott, hogy a fejlődő országok számára több haszonnal járna, ha a kölcsönösségen alapuló multilaterális kereskedelmi rendszerben vennének részt, mint a kereskedelmi preferenciákat biztosító GSP-rendszerben. ${ }^{54}$ Ebből kifolyólag a kedvezmények erózióját nem tartják olyan komoly problémának.

A kereskedelmi kedvezmények ellenére néhány, elsősorban afrikai, ország részesedése a világkereskedelemből csökkent (3.2. táblázat). A fejlődő országok közül Ázsia több mint 10

\footnotetext{
${ }^{54}$ Generalized System of Preferences - Általános Preferencia-rendszer. A dolgozat 4.1. fejezetében részletezzük.
} 
százalékponttal növelte részesedését, azonban Afrika esetében a részesedés a felére esett vissza közel 30 év alatt. Hangsúlyozandó, hogy a táblázat regionális átlagos adatokat tartalmaz, melynek következtében az egyes országok között relatíve jelentős eltérések is lehetnek. Például Afrikában a volt francia gyarmatok esetében a világkereskedelemből való kiszorulás valóban megfigyelhető, míg a korábbi angol gyarmatok esetében a dezintegráció mintha visszafordulna (Subramanian és Tamirisa 2003). Továbbá az is nyilvánvaló, hogy az ázsiai fejlődő országok részesedésnövekedése elsősorban Kínának, illetve Indiának tudható be.

3.2. táblázat Egyes térségek részesedése a világexportból, 1980-2009 (\%)

\begin{tabular}{lccccc}
\hline & $\mathbf{1 9 8 0}$ & $\mathbf{1 9 9 0}$ & $\mathbf{2 0 0 0}$ & $\mathbf{2 0 0 5}$ & $\mathbf{2 0 0 9}$ \\
\hline Fejlett országok & 66,34 & 72,30 & 65,72 & 60,31 & 56,62 \\
\hline Amerika & 14,42 & 14,97 & 16,42 & 12,06 & 11,06 \\
\hline Azsia & 6,68 & 8,59 & 7,92 & 6,07 & 5,06 \\
\hline Európa & 43,89 & 47,33 & 40,18 & 40,96 & 39,06 \\
\hline Océ́nia & 1,34 & 1,41 & 1,21 & 1,22 & 1,44 \\
\hline Fejlódó országok & 29,46 & 24,29 & 31,88 & 36,23 & 39,52 \\
\hline Afrika & 5,99 & 3,14 & 2,32 & 3,03 & 3,09 \\
\hline Amerika & 5,47 & 4,13 & 5,68 & 5,49 & 5,53 \\
\hline Azsia & 17,90 & 16,95 & 23,80 & 27,66 & 30,84 \\
\hline Océánia & 0,11 & 0,08 & 0,08 & 0,06 & 0,05 \\
\hline $\begin{array}{l}\text { Legkevésbé fejlett } \\
\text { országok }\end{array}$ & 0,72 & 0,53 & 0,56 & 0,79 & 1,01 \\
\hline
\end{tabular}

Forrás: saját szerkesztés UNCTAD (2011) adatai alapján

A kereskedelmi preferenciák hatásainak elemzése széles irodalmi háttérrel rendelkezik, a következőkben néhány, általunk fontosnak ítélt kutatást mutatunk be. Özden és Reinhardt (2005) állításával szemben, illetve a 3.2. táblázat adataival némileg ellentmondva, Seyoum (2006) úgy véli, hogy a GSP hasznos a fejlődő országoknak. A szerző az USA és a fejlődő országok közötti kereskedelem alakulását vizsgálta a preferencia-rendszer függvényében, és eredményei szerint a GSP adta kedvezmények szignifikáns és pozitív hatással bírnak minden kedvezményezett ország esetében az USA-ba irányuló exportjukra.

A dolgozat későbbi elemzése szempontjából fontos Cipollina és Salvatici (2010) eredménye: a szerzők az Európai Unió kereskedelmi preferenciáinak hatásait elemezték 161 ország bevonásával a mezőgazdasági kereskedelem bővülésére vonatkozóan. Az eredmények szerint az EU által biztosított preferenciák hozzájárulnak a mezőgazdasági termékek kereskedelmének növekedéséhez, viszont ez régiónként különbözik. Mindezek alapján az a következtetés vonható le, hogy egyes országok, régiók tudnak élni a kereskedelmi kedvezmények adta lehetőségekkel, míg más országok - akár kapacitáshiány, akár 
intézményi fejletlenség okán - nem tudnak aktívan részt venni ebben. A 3.2. táblázat adatai és a fenti kutatások eredményei közötti ellentmondás talán annak tudható be, hogy a pozitív eredményre jutó szerzők nagy mintákkal dolgoztak, melyek elnyomhatták a kedvezőtlen eredménnyel rendelkező régiók és országok eredményeit.

Az egyszerű kereskedelmi hatások mellett Abbott és szerzőtársai (2009) már a kereskedelmi preferenciák fejlődésre gyakorolt hatását is elemezték. A szerzők Vietnámra vonatkozóan vizsgálták a kérdést, és eredményeik szerint a bilaterális kereskedelmi egyezmények jelentős szerepet játszottak az ország gazdasági fejlődésében, valamint a szegénység csökkentésében. Ezen kutatások eredményei pedig azt igazolják, hogy egyrészt a kereskedelmi preferenciáknak jelentős szerepe lehet a gazdasági fejlődésben, másrészt pedig az EU kereskedelmi preferenciáinak kereskedelemélénkítő hatása is lehet. Így későbbi empirikus vizsgálatunk megalapozott és érdemi eredményt hozhat.

A nemzetközi kereskedelem és a gazdasági növekedés, fejlődés közötti kapcsolatot taglaló irodalom áttekintése során nehéz egyértelmű következtetéseket levonni (3.3. táblázat). A kutatás során áttekintett irodalom alapján három fő vonalon lehet a kereskedelmi hatásokat megítélni:

- az adott szempont és a nemzetközi kereskedelem között pozitív, vagy

- az adott szempont és a nemzetközi kereskedelem között negatív kapcsolat mutatható ki, illetve

- ugyan kimutatható a kapcsolat, de azt nagyban befolyásolja az intézmények minősége, rugalmassága.

Hangsúlyozandó az is, hogy az elemzések eredményeit jelentősen befolyásolja az, hogy milyen mintán és milyen módszer felhasználásával dolgoztak. A módszerek között néhol jelentős leegyszerüsítést találhatunk (például a GDP és az áru- és szolgáltatásexport különbségével kezelt endogenitási probléma), vagy néhány tényezőt figyelmen kívül hagynak (például a vállalatok versenyképessége, vagy a megnövekedett import miatti egyensúlytalanság), ami szintén hatással van az elemzések kimenetelére. Viszont - ahogy arra a 3.2. táblázat is rámutat - egyes térségek és országok már-már kiszorulnak a nemzetközi munkamegosztásból, ami már saját háttérintézményük, infrastruktúrájuk fejletlenségének is betudható. Összességében - a fenti kritikákkal együtt - elfogadható az, hogy a nemzetközi kereskedelemben való részvétel pozitív hatással lehet a fejlődő országok gazdasági 
növekedésére és fejlődésére - függetlenül a jövedelmi helyzetüktől -, viszont a hatás mértéke nagymértékben függ az ország intézményi felkészültségétől. A jövedelmi helyzettel kapcsolatban szem előtt tartva azt a tényt, hogy nem egyértelmü: a fejlett intézményi háttér járul hozzá a magasabb jövedelmi szinthez, vagy a magasabb jövedelmi szint eredményez fejlettebb intézményi hátteret (Acemoglou et al 2001).

3.3. táblázat A kereskedelem lehetséges hatásainak megítélése

\begin{tabular}{|c|c|c|c|}
\hline Szempont & Egyértelmüen pozitív & Egyértelmüen negatív & Intézmények szerepe \\
\hline $\begin{array}{l}\text { Jövedelmi szint: } \\
\text { közepes jövedelmü } \\
\text { országok }\end{array}$ & $\begin{array}{c}\text { Meschi-Vivarelli (2009), } \\
\text { Dodaro (1991), Subasat } \\
\text { (2002) }\end{array}$ & $\begin{array}{c}\text { Balassa (1985), } \\
\text { Sentsho }(2003), \\
\text { Wilbur-Haque (1992) }\end{array}$ & Freund-Bolaky (2008) \\
\hline $\begin{array}{l}\text { Gazdasági } \\
\text { növekedés }\end{array}$ & $\begin{array}{c}\text { Yanikkaya (2003), } \\
\text { Salahudin-Islam (2008), } \\
\text { Manole-Spatareanou } \\
(2010), \text { Haddad et al } \\
(2010), \text { Subasat }(2002)\end{array}$ & $\begin{array}{l}\text { Rodríguez-Rodrik } \\
\text { (1999) }\end{array}$ & $\begin{array}{c}\text { Dreger-Herzer }(2011), \\
\text { Chang et al }(2009), \\
\text { Freund-Bolaky (2008), } \\
\text { Dodzin-Vamvakidis } \\
(2004), \text { Winters et al } \\
(2004), \text { Nenci-Pietrobelli } \\
(2007)\end{array}$ \\
\hline $\begin{array}{l}\text { Gazdasági } \\
\text { diverzifikáció }\end{array}$ & $\begin{array}{c}\text { Dodzin-Vamvakidis } \\
\text { (2004), Karbasi-Tavana }\end{array}$ & & \\
\hline $\begin{array}{l}\text { Költségvetési } \\
\text { hiány }\end{array}$ & & $\begin{array}{c}\text { Combes-Saadi-Salik } \\
(2006)\end{array}$ & Agbeyegbe et al (2006) \\
\hline $\begin{array}{l}\text { Kereskedelmi } \\
\text { preferenciák }\end{array}$ & $\begin{array}{c}\text { Seyoum (2006), } \\
\text { Cipollina-Salvatici } \\
(2010), \text { Abbott et al } \\
(2009)\end{array}$ & $\begin{array}{c}\text { Özden-Reinhardt } \\
\text { (2005) }\end{array}$ & \\
\hline $\begin{array}{l}\text { Jövedelem- } \\
\text { egyenlőtlenség }\end{array}$ & $\begin{array}{c}\text { Dobson-Ramlogan } \\
\text { (2009), Meschi-Vivarelli } \\
\text { (2009) }\end{array}$ & & \\
\hline
\end{tabular}

Forrás: saját szerkesztés

Ugyan felismerik a fejlődő országok nehezebb alkalmazkodását a multilaterális kereskedelmi rendszerhez, azonban megoldás még nem született a problémára. Azt nem lehet tudni, hogy ennek-e, vagy a neoklasszikus felfogás terjedésének következtében, de egyre több nemzetközi szervezet nyilvánosan is azt vallja, hogy a nemzetközi kereskedelemben való részvétel segíthet a fejlődő országok problémáinak megoldásában, felszámolásában, néhol kiegészítésként megtaláljuk az előzőekben kihangsúlyozott intézmények szerepét is. A következőkben ezeket tekintjük át.

\subsubsection{NEMZETKÖZI SZERVEZETEK VÉLEMÉNYE A NEMZETKÖZI KERESKEDELEM}

\section{SZEREPÉRŐL}

Az elmúlt néhány évből számos utalást és számos dokumentumot találhatunk arra vonatkozóan, hogy a fejlesztési segélyezés mellett az önjáró fejlődést biztosít(hat)ó 
nemzetközi kereskedelem is fontos szerepet játszik egy-egy ország gazdasági fejlödésének elérésében (3.4. táblázat). Az explicit megjelenés mellett azonban nem feledkezhetünk meg arról, hogy a Kereskedelmi Világszervezet ma már 150 feletti taglétszámmal rendelkezik, ennek következtében a liberalizációs hullám szinte univerzális lett: ma már megkerülhetetlen az, hogy egy ország ne vegyen részt a nemzetközi munkamegosztásban.

3.4. táblázat A nemzetközi kereskedelem fontossága

\begin{tabular}{lc}
\hline Nemzetközi szervezet & Főbb dokumentumok/események \\
\hline Kereskedelmi Világszervezet & $\begin{array}{c}\text { Doha Fejlesztési Forduló (2001) } \\
\text { Aid for Trade (2005) }\end{array}$ \\
\hline UNCTAD & $\begin{array}{c}\text { Trade and Development Report (2005, } \\
\text { évente) }\end{array}$ \\
\hline ENSZ & $\begin{array}{c}\text { Monterrey Konferencia (2002) } \\
\text { Millenniumi Fejlesztési Célok (2000) }\end{array}$ \\
\hline Európai Unió & Európai Konszenzus (2005) \\
\hline saját szerkesztés &
\end{tabular}

Forrás: saját szerkesztés

A következőkben három nemzetközi szervezetet emelünk ki: a Kereskedelmi Világszervezet mellett kitérünk az ENSZ-re, valamint annak egy alprogramjára, az UNCTAD-ra. ${ }^{55}$ Bár a Kereskedelmi Világszervezet nem fejlesztési intézmény, viszont érdemes néhány pontot kiemelni, amely igazolja azt, hogy a nemzetközi kereskedelem fejlődésben betöltött szerepét elfogadja. Egyrészt, ahogy arra már utaltunk, a WTO széles tagsággal rendelkezik a maga 153 tagjával, melyek kétharmada fejlődő ország, a taglétszám pedig elörevetíti azt, hogy a nemzetközi munkamegosztásból ma már nem lehet kimaradni. Másrészt, a 2001-ben elindított újabb liberalizációs forduló a Doha Fejlesztési Forduló nevet viseli, amely a multilaterális kereskedelmi rendszer adta lehetőségeken belül fejlesztési elemeket is tartalmaz - részben az Uruguayi Forduló magas követelményei miatt (Hoekman 2002, Hoekman és Özden 2005), és többek között a piacra jutás fejlődését, a jogalkotást és annak érvényesítését tartalmazza (Hoekman 2002). Harmadrészt, 2005-ben a Hongkongi Miniszteri Konferencián a WTO programjai közé emelték az Aid for Trade programot, mely olyan segélyezés, ami a fejlődő országok kereskedelmi lehetőségeinek bővítésére, fejlesztésére fókuszál.

Ezek az elemek rámutatnak arra, hogy a Kereskedelmi Világszervezet felismerte saját szerepét, illetve saját tevékenységének hatásait, és lehetőségeihez mérten igyekszik

\footnotetext{
${ }^{55}$ Az Európai Unióban lévő nézetet itt nem részletezzük, erről a dolgozat 5. fejezetében szólunk bővebben.
} 
figyelembe venni a fejlődő országok korlátozottabb helyzetét. A WTO mellett az ENSZ is jelentős szerepet játszik a fejlődő országok életében, azonban sokkal nagyobb mozgástere van a fejlesztést tekintve. Az ENSZ tevékenysége kapcsán az alábbi lépések emelhetők ki, melyek a nemzetközi kereskedelem szerepét hangsúlyozzák:

- 2000-ben fogadták el a Millenniumi Fejlesztési Célokat, melyek közül a 8. cél a globális partnerség szükségességét fogalmazza meg. Ezen belül pedig prioritásként szerepel az alábbi (UN 2000): „Továbbfejleszteni a nyitott, szabályokon alapuló, kiszámitható és diszkrimináció-mentes kereskedelmi és pénzügyi rendszert”, ennek kedvező hatása pedig a piacra jutás könnyebbé válásában és a mezőgazdasági vámok csökkenésében érhetö tetten.

- 2003-ban fogadták el a Monterrey Konszenzust a fejlesztés finanszírozásáról szóló nemzetközi konferencia keretében. Ebben a dokumentumban a nemzetközi kereskedelem és a fejlődés összefonódása explicit módon megjelenik, ahogy a dokumentum fogalmaz (UN 2003, 12. o.): „Egy univerzális, szabályozott, nyitott, diszkrimináció-mentes és igazságos multilaterális kereskedelmi rendszer, valamint értelmes kereskedelmi liberalizáció, világszerte jelentösen elösegitheti a fejlödést."

Az ENSZ egyik szakosított programját, az UNCTAD-ot külön érdemes megemlíteni. Az UNCTAD az ENSZ Kereskedelmi és Fejlesztési Konferenciája, mely évente adja ki az ún. Trade and Development Report-ot. A 2005-ös jelentés alapján a nemzetközi kereskedelemben való részvétel a fejlődés eszközének tekinthető (UNCTAD 2005a, 11. o.): „Fontos a kereskedelemre úgy tekinteni, mint egy olyan eszközre, ami segít elérni a végsö célt, nevezetesen az emberek jólétét." Ezekben a jelentésekben a kereskedelem és a fejlődés közötti kapcsolatot vizsgálják, és a kapcsolat meglétének igazolására kidolgozták az ún. TDI ${ }^{56}$ mutatót. Az indikátor kialakítása mögött az az elv húzódik meg, hogy egyetlen egy ország sem növekedett kereskedelem nélkül, és ma már a globalizáció miatt a kereskedelemnek még nagyobb szerepe lett a fejlődés folyamatában (UNCTAD 2005b).

Mivel a TDI későbbi empirikus kutatásunk szempontjából kiemelten fontos, így részletes bemutatása elengedhetetlen. A TDI számszerüsítése három dimenzió kapcsolatára és az azok által meghatározott indikátorokra épül (3.5. táblázat) (UNCTAD 2005b). A TDI meghatározása ezen dimenziókhoz rendelt indikátorok fökomponens-analízise, illetve ezen főkomponensek regressziós modellje alapján történik. A TDI-nek nincs felső határa, és a magasabb értéke magasabb kereskedelmi teljesítményt és fejlettségi szintet jelent,

\footnotetext{
${ }^{56}$ Trade and Development Index - Kereskedelmi és fejlődési index
} 
következésképpen a mutató értékének növekedése javuló teljesítményre utal. Mivel később nem számolták ki az index értékét, a 2005-ös eredményekre tudunk támaszkodni (UNCTAD 2005b).

3.5. táblázat A TDI felépítése

\begin{tabular}{|c|c|c|}
\hline Dimenzió & Komponensek & Indikátorok \\
\hline \multirow[t]{6}{*}{$\begin{array}{l}\text { Strukturális és } \\
\text { intézményi }\end{array}$} & Humán tőke & $\begin{array}{l}\text { egy före jutó egészségügyi kiadás; egy diákra } \\
\text { jutó kiadás }\end{array}$ \\
\hline & Fizikai infrastruktúra & $\begin{array}{l}\text { aszfaltozott utak aránya; légi repülések } \\
\text { száma; } 1000 \text { lakosra jutó telefonvonalak } \\
\text { száma }\end{array}$ \\
\hline & Intézményi minőség & bürokrácia minősége; korrupció szintje \\
\hline & Gazdasági struktúra & mezőgazdaság aránya a GDP-ben \\
\hline & Környezeti fenntarthatóság & $\begin{array}{l}\text { megfelelő vízhez jutás; közegészségügyi } \\
\text { ellátáshoz való hozzájutás; egy före jutó } \\
\text { energiahasználat GDP-arányosan }\end{array}$ \\
\hline & Pénzügyi környezet & $\begin{array}{l}\text { magánszektor belföldi hiteleinek aránya a } \\
\text { GDP-hez viszonyítva }\end{array}$ \\
\hline \multirow[t]{2}{*}{$\begin{array}{l}\text { Kereskedelempolitika } \\
\text { és folyamata }\end{array}$} & Kereskedelmi nyitottság & $\begin{array}{l}\text { átlagos vámszínvonal; az átlagos vámszint } \\
\text { háromszorosát meghaladó termékek aránya; } \\
15 \% \text { feletti vámmal rendelkező termékek } \\
\text { aránya; the share of lines with specific tariffs }\end{array}$ \\
\hline & Hatékony piacra jutás & $\begin{array}{l}\text { ipari export aránya a teljes áruexporton belül; } \\
\text { export koncentrációs index }\end{array}$ \\
\hline \multirow[t]{3}{*}{ Fejlettség szintje } & Gazdasági fejlettség & egy forre jutó GDP (PPP) \\
\hline & Társadalmi fejlettség & $\begin{array}{l}\text { felnőttek írni-olvasni tudása; iskolába járók } \\
\text { aránya; születéskor várható élettartam }\end{array}$ \\
\hline & Nők helyzete & Gender Development Index \\
\hline
\end{tabular}

Forrás: saját szerkesztés UNCTAD (2005b) alapján

A 2005-ös eredmények szerint az első húsz ország között kizárólag fejlett országok találhatók (Szingapúr a maga 15. helyével kivétel ${ }^{57}$ ), és az első harmincba mindössze három fejlődő ország került be (Szingapúr, Dél-Korea, Malajzia). A 110 országot tartalmazó lista végén találhatók a legkevésbé fejlett (afrikai) országok, az utolsó tíz helyen kizárólag afrikai ország szerepel, ebből kilenc a legkevésbé fejlettek közé tartozik. Már ez is előrevetíti azt, hogy a fejlődő országok közül a fekete-afrikai országok átlagosan a legalacsonyabb TDIértékekkel rendelkeznek, míg a kelet-ázsiai és csendes-óceáni régióban található fejlődő államok teljesítenek a mutató szerint a legjobban. A TDI eredményei alapján levonható következtetések alapján elsősorban az afrikai fejlődő országok nem tudják kihasználni a kereskedelem adta lehetőségeket a gazdasági fejlődés elérésében.

$\mathrm{Az}$ áttekintett irodalmi megközelítések, az elözőekben bemutatott nemzetközi hozzáállás és eredmények alapján a fejlődő országok gazdasági fejlődésének előmozdítása érdekében a kifejezetten a kereskedelemhez szükséges kínálatoldali kapacitások és

\footnotetext{
${ }^{57}$ Dánia, Amerikai Egyesült Államok, Egyesült Királyság áll az első három helyen, Magyarország a 26. helyen található (UNCTAD 2005b).
} 
intézmények fejlesztését célzó támogatás elengedhetetlennek tünik. Az Aid for Trade kezdeményezés esetükben így kiemelt lehetőség lehet. Mivel több tanulmányban is megjelent az intézmények szerepe a nemzetközi kereskedelemből nyerhető haszon kapcsán, így fontos a továbbiakban az Aid for Trade irányában folytatni elemzésünket.

\subsection{AZ AID FOR TRADE}

A nemzetközi kereskedelemben való részvétel fejlesztése nem kizárólag kereskedelmi preferenciákon keresztül történhet, hanem a nemzetközi segélyezés is hatással lehet rá. Napjainkban ez pedig különösen fontos, hiszen 2005-ben indították útjára az Aid for Trade programot. Ezzel a beavatkozással egyrészt a kereskedelem gazdasági fejlődésben betöltött szerepét erősítik tovább, másrészt pedig a segélyezés és a kereskedelem mint fejlesztési eszközök összekapcsolódnak egymással. Először azonban érdemes kitérni arra, hogy az eddigi segélyezési gyakorlat alapján milyen következtetések vonhatóak le a fogadó országok kereskedelmének alakulásáról. Ezután az Aid for Trade alapjait részletezzük, majd bemutatjuk, hogy a nemzetközi kutatásokban hogyan ítélik meg az Aid for Trade kereskedelembővítő hatásait. Ezzel célunk a dolgozat 5.5. fejezetében bemutatásra kerülő empirikus vizsgálat alapjának megteremtése.

\subsubsection{A NEMZETKÖZI SEGÉLYEK KERESKEDELMI HATÁSAI}

Ugyan a dolgozat 3.1. fejezetében már részleteztük a nemzetközi fejlesztési együttmüködés főbb problémáit, viszont attól elkülönülten érdemes kezelni a segélyezés hatását a kereskedelem alakulására, hiszen ez sokkal inkább kötődik az Aid for Trade-hez, mint a segélyezés problémáihoz. Mindemellett ez esetben már két beavatkozási lehetőség összekapcsolásáról beszélünk. Annak érdekében, hogy lássuk az Aid for Trade jelentőségét és sajátos helyzetét, fontos megismerni azt, hogy az általános segélyezés és a kereskedelem közötti kapcsolat vizsgálata során milyen eredményre jutottak: mit, milyen indikátorokkal és milyen módszerekkel vizsgáltak. Az itt leszürt általános megállapítások hozzájárulnak ahhoz, hogy megfelelő módszerrel dolgozzunk saját empirikus vizsgálatunk során. A segélyezés és a kereskedelem közötti kapcsolat vizsgálata leggyakrabban az ún. gravitációs modellek segítségével történik, viszont a modell módszertani kérdéseit nem itt, hanem saját empirikus vizsgálatunk során fogjuk részletezni (5.5.2. fejezet).

Rajan és Subramanian (2011) a segélyek és az ipari export növekedése közötti kapcsolatot vizsgálták regressziós modell segítségével, a hangsúly a holland kór jelenségének 
kimutathatóságán volt. Eredményeik szerint a segélyeknek valóban lehet az export növekedésével ellentétes hatása, ami elsősorban az árfolyam felülértékelődésén keresztül követhető nyomon, viszont az árfolyamrendszer befolyásolja ennek alakulását. E kedvezőtlen folyamat elsődleges oka pedig lényegében a segélyek beáramlása. Konkrét elemzések is születtek a segélyek donor, valamint fogadó ország exportjának változására gyakorolt hatásait illetően. Wagner (2003) a kötött segélyeknek ${ }^{58}$ a donor országok exportjára gyakorolt hatásait elemezte gravitációs modell segítségével. Eredményei szerint a segély minden egyes dollárjából 35 cent közvetlenül visszakerül a donor országhoz a segélyekhez közvetlenül kapcsolódó export formájában, míg 95 cent a segélyekhez közvetett módon kapcsolódó export révén. A későbbi empirikus vizsgálatunk szempontjából fontos az a megállapítása is, hogy a segélyek kereskedelmi hatásai leginkább az adományozás évében, nem pedig egy-két évvel később jelentkeznek. E kutatással ellentétes eredményre jutottak Osei és szerzőtársai (2009) tanulmányukban. Eredményeik szerint ugyan a teljes minta esetében a pozitív kapcsolat kimutatható volt, a kisebb részminták esetében nem találtak bizonyítékot arra, hogy a kötött segélyek növelnék a donorok és a fogadó országok közötti kereskedelmet, bár közöttük nagyobb volumenü kereskedelem zajlik.

Nowak-Lehmann D. és szerzőtársai (2011) viszont már a fogadó (recipiens) országok szempontjából elemezték a segélyek és a kereskedelem közötti kapcsolat alakulását, továbbra is a segélyezést általánosságban véve. A szerzők széles körű elemzést folytattak a 130 fogadó országot és 21 donor országot tartalmazó mintájukkal. A vizsgálat középpontjában az export alakulása állt, amit - a korábbiakban bemutatott tanulmányokhoz hasonlóan - gravitációs modell segítségével próbálták magyarázni. A tanulmányban többféle modellel is találkozhatunk, és ezek eredményei szerint, ha nem vonják kontroll alá a bilaterális kereskedelmi kapcsolatokat valamint az autokorrelációt, akkor a segélyek szignifikáns hatása kimutatható, a sokkal finomabb modellek esetében viszont a segélyek inszignifikánssá válnak az exportra nézve, ami - a szerzők szerint - teljes mértékig összhangban van a más tanulmányokban is kiemelt makrogazdasági folyamatok negatív hatásaival. Továbbá a szerzők nem tudták kimutatni azt sem, hogy a bilaterális segély növelné a bilaterális kereskedelmet (ahogyan az talán várható lenne). Végső konklúziójuk szerint a segélyek közvetlen hatása nem mutatható ki ugyan az export növekedését illetően, viszont nem zárható ki, hogy közvetett hatásuk van a kereskedelmi folyamatokra. Ezek ismeretében

\footnotetext{
${ }^{58}$ Kötött segély alatt azt értjük, amikor a donor az adott segélyért exportál a fogadó országba (lényegében elöírják, hogy a recipiensek a donortól importáljanak), hogy maga a donor (és az adófizetők) is nyerjen a segélyezésen (Wagner 2003).
} 
érdekes kérdés, hogy az Aid for Trade, ami kifejezetten kereskedelem-fókuszú támogatás, miképpen tud hozzájárulni a kereskedelem bővüléséhez.

A fenti két eredmény „egyvelegét” adja Pettersson és Johansson (2011) munkája. Kutatásuk során 184 ország bevonásával készült gravitációs modell eredményei alapján a segély nem kizárólag a donor exportját növeli meg a fogadó ország irányába, hanem a recipiens ország exportja is növekszik. Mindezeket áttekintve pedig a későbbi empirikus vizsgálatunk szempontjából fontos tanulság, hiszen a segélyezéssel így nem kizárólag az export, hanem az import oldalt is vizsgálni szükséges a fogadó ország szempontjából, szem előtt tartva azt, hogy ez akár külkereskedelmi egyensúlytalansághoz is vezethet.

E kutatások alapján nem lehet egyértelmü következtetéseket levonni a nemzetközi segélyezés kereskedelembővítő hatásairól. Sőt, az sem egyértelmü, hogy a segélyezés mely évben fog hatni a kereskedelem bővülésére. Ebből kifolyólag érdekes kérdés az, hogy mi történik akkor, ha a fókuszált segélyezés történik, ami kifejezetten azoknak a tényezőknek a fejlesztésére irányul, amelyek a nemzetközi kereskedelemben való hatékony részvételt akadályozhatták. Erre szolgálna ugyanis az Aid for Trade. Hoekman (2002) kifejezetten támogatja ezt a koncentráltabb és egyértelmű fókusszal rendelkező segélyezési formát, és úgy véli, hogy ezzel a multilaterális kereskedelmi rendszer a fejlődő országok számára is hasznos lehet, azaz a globális kereskedelmi rendszer a fejlődés lehetőségét is megteremti. Mivel az Aid for Trade kezdeményezés a dolgozatban végzendő empirikus vizsgálat alapját képezi, így fontos részleteiben is megismerni.

\subsubsection{Az Aid FOR Trade AlAPJAI}

2001-ben a Kereskedelmi Világszervezet új tárgyalási fordulót indított el a további liberalizáció érdekében: a fejlődő országok kérésének megfelelően a tárgyalások lényegi pontját képezi a fejlesztés is, ennek megfelelően az új forduló a Doha Fejlesztési Forduló nevet viseli. ${ }^{59}$ Azonban az Aid for Trade (AfT, Segély a kereskedelemért) kezdeményezés nem jelenik meg a Doha Fejlesztési Agendában (Doha Development Agenda), gyökerei mindössze a hat évvel ezelőtt tartott skóciai G8-as csúcstalálkozóig nyúlnak vissza (Hoekman és Wilson 2010), majd a 2005 végén megrendezett Hongkongi Miniszteri Konferencia záródokumentumában jelenik meg. Életre hívásának oka elsősorban a fejlődő országok világkereskedelemben elfoglalt kedvezőtlen gazdasági helyzete, ami többek között az

\footnotetext{
${ }^{59}$ Deardorff és Stern (2009) kritikusan felhívják arra a figyelmet, hogy a fejlesztés kifejezés félrevezető lehet, hiszen a fejlődés - az ő értelmezésük szerint - azt jelenti, hogy tovább csökkennek a nemzetközi kereskedelem elött álló akadályok, azaz további kereskedelmi liberalizációra kerül sor.
} 
Uruguayi Fordulón vállalt kötelezettségek, a folyamatosan csökkenő vámok, a kereskedelmi preferenciák „elértéktelenedése” következtében alakult ki (Evenett 2008, Laird 2007, Page 2007). ${ }^{60}$

Már több évtizede nyilvánvaló, hogy a fejlödő országok többsége képtelen alkalmazkodni az új nemzetközi kereskedelmi körülményekhez (lásd korábban a 3.2. táblázat adatait), így számukra valamilyen megoldást kellett találni: az Aid for Trade 2005-ös megjelenése után fél évvel sikerült a program céljait és az általa lefedett területeket meghatározni (Gamberoni és Newfarmer 2009, WTO 2005, 2006). A hivatalos dokumentumok alapján az Aid for Trade kezdeményezés három célja határozható meg (WTO 2006): (i) a fejlődő, de különösen a legkevésbé fejlett országok exportnövekedésének elérése; továbbá (ii) ezen országok bekapcsolása a multilaterális kereskedelmi rendszerbe; ezáltal (iii) ők is élvezzék a liberalizáció előnyeit.

A célok megvalósulása érdekében hat területre lehet támogatást kapni az AfTprogramon keresztül (WTO 2006). Ezek hozzájárulhatnak ahhoz, hogy a kereskedelem előtt álló külső korlátozások (vámok és egyéb kereskedelempolitikai eszközök) mellett a belső akadályok is elháruljanak a nemzetközi kereskedelemben való aktív részvétel elől (Gamberoni és Newfarmer 2009). A hat terület a következö:

1. Kereskedelempolitika és szabályozás. A kereskedelmi tárgyalásokon résztvevők képzését, vitás ügyekben a hatékony részvételre való felkészítését foglalja magában. Továbbá intézményi és technikai támogatás biztosítja, hogy a multilaterális kereskedelmi egyezményeket, kötelezettségvállalásokat nemzeti keretek között is végre tuják hajtani.

2. Kereskedelemfejlesztés, ami a beruházás-ösztönzést, a szolgáltatások kereskedelméhez szükséges intézmények támogatását, az üzleti szolgáltatásokat és intézményeket, az e-kereskedelmet, valamint a piacelemzést és -fejlesztést fedi le.

3. Kereskedelemmel összefüggö infrastruktúra, melynek során lehetőség nyílik a fizikai infrastruktúra (úthálózat, kikötők, telekommunikáció, energia-hálózat) fejlesztésére.

\footnotetext{
${ }^{60}$ A dolgozatnak nem tárgya az Aid for Trade kialakulása mögött meghúzódó tényezők részletes vizsgálata, ezeket részletesen lásd Evenett (2008), Hoekman és Wilson (2010), Laird (2007), Page (2007), valamint Udvari (2009a) tanulmányában.
} 
4. Termelési kapacitás kiépítése, ami a gazdasági szektorok megerősítésére ad lehetőséget az üzleti környezet, a banki szolgáltatások, a pénzügyi intézmények, valamint a turizmus fejlesztése által.

5. Kereskedelemmel összefüggő alkalmazkodási támogatás. Lényegében költségvetési támogatás, melynek célja a kereskedelem liberalizálásából eredő költségek fedezése (a csökkenő kedvezmények és a csökkenő vámok következményének ellensúlyozása), valamint a kereskedelmi reformok végrehajtása.

6. Egyéb kereskedelemmel kapcsolatos igények, mely lehetőséget biztosít arra, hogy minden nemzetközi kereskedelemhez kötődő kezdeményezésre támogatást nyújtsanak.

Ezek a beavatkozási területek a fizikai és a humán infrastruktúra fejlesztésére is hangsúlyt helyeznek, és a fejlődő országokban lévő kínálatoldali kapacitás fejlesztése az elsődleges cél (Hallaert és Munro 2009), ami végül a kereskedelem és az üzleti környezet fejlődéséhez vezet. Ezek a tényezők pedig - ahogyan a dolgozat 3.2.3. fejezetében Freund és Bolaky (2008), valamint Dreger és Herzer (2011) tanulmánya alapján rámutattunk - a kereskedelem pozitív hatásainak megjelenése érdekében fontos tényezők. Ezek teljesülése révén pedig nem kizárólag a nemzetközi kereskedelemben való szerepvállalásuk javul, hanem az ország a külföldi tőke számára is vonzóvá válhat, valamint gazdasági növekedést érhet el. Végeredményben pedig a szegénység is csökken (3.2. ábra). Az előzőek alapján egyértelmű, hogy mindez megfelelő intézményi környezetben valósulhat meg.

$\mathrm{Az}$ Aid for Trade területeit áttekintve egyértelmüen elfogadható, hogy az AfT pénzügyi és egyben technikai segélyt is jelent (Hoekman és Wilson 2010), azonban a pénzügyi oldala erősebbnek tünik. Ennek következtében pedig az AfT hatékonysága kétségeket ébreszthet, hiszen jelen dolgozat 3.1. fejezetében is érintettük a nemzetközi segélyezés problémáit. Emellett pedig a pénzügyi segélyek és a gazdasági növekedés közötti kapcsolat sem egyértelmű: a kereskedelmi nyitottság hatásaihoz hasonlóan empirikus úton igazolták mind a pozitív, mind pedig a negatív kapcsolatot a segélyek és a gazdasági növekedés között (Cali és te Velde 2011, Doucouliagos és Paldam 2007, Hoekman és Wilson 2010). Mivel a segélyek hatásai nem egyértelmüek, ezért az AfT-t illetően is óvatosan kell fogalmazni. 
3.2. ábra Az Aid for Trade müködési mechanizmusa

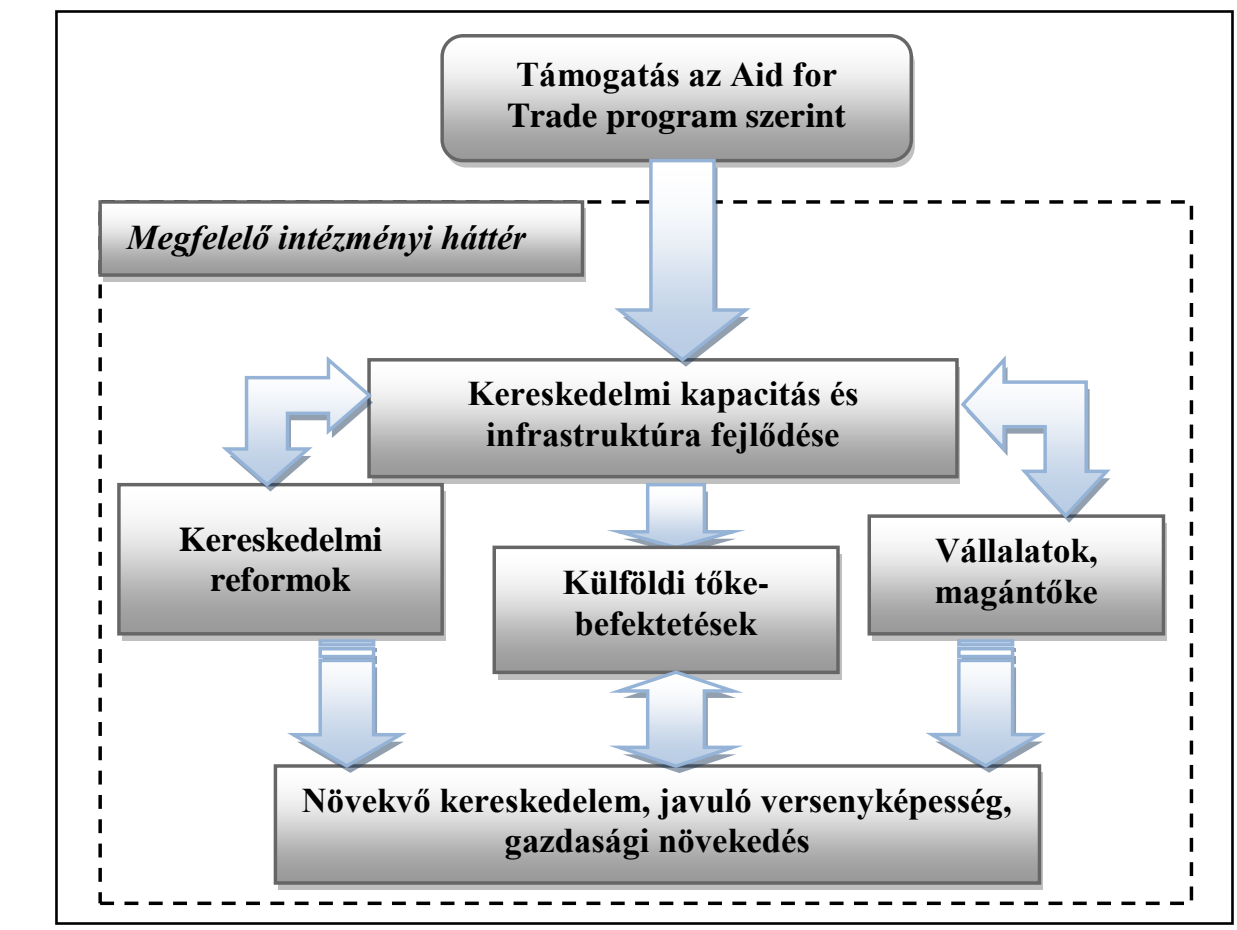

Forrás: saját szerkesztés Udvari (2009b), 75. o. alapján

Magának az Aid for Trade-nek a létrehozását két oldalról szükséges megközelíteni: az előnyöket és a hátrányokat is figyelembe kell venni, ami mind a fejlődő országokat, mind a nemzetközi közösséget érinti (3.6. táblázat). Kiemelendő, hogy a nemzetközi közösség felismerte, hogy a fejlődő országok nemzetközi kereskedelemben való megjelenése érdekében tenniük kell valamit, illetve mivel a fejlődő országok kérték a program létrehozását, nyilvánvaló, hogy nem elzárkózni akarnak a további liberalizációtól, mindössze olyan támogatást szeretnének pluszban, melyekkel kereskedelmi lehetőségeiket javíthatják. Azaz az Aid for Trade létrehozása ebből a szempontból mind a fejlett, mind a fejlődő országok számára kedvező. Mindemellett fontos tényező - mindkét fél szempontjából - az is, hogy a WTO mindebben szerepet vállal, hiszen a szervezetnek számos fejlődő ország a tagja, illetve a WTO egyezményei (is) hozzájárultak a kedvezőtlen helyzet kialakulásához. A WTO részvételével pedig a multilaterális szintű megoldás esélye nagyobb. Továbbá az Aid for Trade célzottan a kínálatoldali kapacitások fejlesztésére törekszik, ezzel pedig azokat a tényezőket javítja, melyek hosszú távú lehetőségeket biztosítanak a fejlődő országok számára, és nem ad hoc jellegü beavatkozások. 
3.6. táblázat Az Aid for Trade létrejöttének erősségei, kritikái

\begin{tabular}{cc}
\hline Erősség & Kritika \\
\hline A probléma nemzetközi szintü felismerése & WTO szerepe nem ismert \\
\hline Fejlődő országok kérték a létrehozását & $\begin{array}{c}\text { AfT nem a kereskedelmi liberalizációról } \\
\text { szól, így nem illik a WTO tevékenységébe }\end{array}$ \\
\hline Multilaterális szintü megoldás & $\begin{array}{c}\text { Pénzügyi támogatás - legkevésbé fejlett } \\
\text { országok támogatása kétséges }\end{array}$ \\
\hline Kínálatoldali kapacitás fejlesztése & $\begin{array}{c}\text { Forrásbővítés vagy -átcsoportosítás? } \\
\text { Jogosultsági kör, stratégia }\end{array}$ \\
\hline & Hiányzó statisztika - megfeleló értékelés? \\
\hline
\end{tabular}

Forrás: saját szerkesztés Udvari (2009a) alapján

Ezek mellett azonban számos olyan tényező emelhető ki, ami homályossá teszi az Aid for Trade létét, ezáltal pedig kedvezőtlen hatással lehet mind a fejlődő, mind a fejlett országokra. Az Aid for Trade negatív oldalát illetően ki kell emelni, hogy a WTO szerepe nem ismert pontosan ezen kezdeményezést illetően: mennyiben játszik szerepet a koordinálásban, a fejlesztésben? Továbbá az Aid for Trade nem a WTO feladatköreibe tartozó kereskedelmi liberalizációról szól, így nem is illik bele a WTO tevékenységébe, így miért a WTO foglalkozik ezzel? Mindemellett megemlíthető az Aid for Trade pénzügyi jellege és a pénzügyi támogatásokhoz kötődő összes kétség, amit a dolgozat 3.1. fejezetében már kifejtettünk. Ugyan pénzügyi támogatásról van szó, viszont nem egyértelmü, hogy forrásbővítésről, vagy szimplán a források átcsoportosításáról van szó. További hátrány, hogy mögötte nem húzódik meg stratégiai dimenzió, mellyel a hatékonysága növelhető lenne (Huchet-Bourdon et al 2009). Emellett nem ismert a jogosultak köre sem: minden fejlödő ország részesülhet ilyen jellegü támogatásban, vagy csak a bizonyos szint alatti kereskedelmi tevékenységgel rendelkező ország, azaz Kína mint fejlődő de jelentős exportőr ország szintén részesülhet támogatásban a programból? Az OECD adatbázisa, valamint a legújabb globális Aid for Trade-jelentés (OECD és WTO 2011) alapján például Kína is részesül Aid for Tradenek minősülő támogatásban.

Az Aid for Trade létével kapcsolatos kritika az, hogy összesített, egységesen mért adatok, statisztikák nem érhetőek el az Aid for Trade-re vonatkozóan. Hogyan lehet így mérni és elemezni a hatékonyságát? Bearce és szerzőtársai (2010) által megfogalmazottak teljesen megfelelnek azoknak a tapasztalatoknak, melyekkel saját kutatásunk során találkoztunk: egyértelmű Aid for Trade-adatok nem érhetők el a leggyakrabban használt OECDadatbázisban, csak az egyes szektorokra juttatott támogatások összegeként lehet meghatározni annak nagyságát. Viszont ennek komoly hátránya, hogy olyan segélyezési adatok is 
belekerülnek, amelyeket elsődlegesen nem kereskedelemfejlesztési céllal nyújtottak a donorok. Azonban jobb megoldás egyelöre nincs, így számos kutatás a szektorok szerinti összegzés alapján von le következtetést. ${ }^{61}$

\subsubsection{AZ AID FOR TRADE LEHETSÉGES KERESKEDELMI HATÁSAI}

Hoekman és Wilson (2010) szerint az AfT-re kiemelt szükség van a jelenlegi válságos időben, hiszen a nemzetközi kereskedelem révén a szegény országok is kilábalhatnának a kedvezőtlen gazdasági visszaesésből. Emellett a szerzők úgy vélik, hogy az Aid for Trade a gazdasági diverzifikációt is erősítené, valamint a termelékenységet is javítaná ezekben az országokban. Mivel az AfT célzott támogatásként a kereskedelmi kapacitás fejlesztését segíti elő, így - a szerzők szerint - a segélyezés negatív hatásai (mint például a holland kór) elkerülhetővé válnak. Az elmúlt néhány évben az Aid for Trade lehetséges hatásainak elemzése nemzetközi szinten egyre jelentősebb szerepet játszik, és mivel jelen dolgozatban konkrét empirikus elemzés irányul az Európai Unióból származó Aid for Trade-támogatások hatásainak vizsgálatára, így a következőkben e kutatások eredményeit tekintjük át.

Az általános segélyezés és a kereskedelem közötti kapcsolatot illetően vegyes eredmények jelennek meg, viszont az Aid for Trade-központú vizsgálatok már sokkal egységesebbek végkövetkeztetésüket illetően. A nemzetközi szakirodalomban található elemzések két oldalról közelítik meg az AfT lehetséges hatásainak vizsgálatát: a kereskedelmi költségekre gyakorolt hatása mellett vizsgálják az exportvolumen változását is. Az eddigi - és kutatásunk során fellelt - empirikus vizsgálatok szinte minden esetben pozitív eredménnyel zárultak (3.7. táblázat). Hangsúlyozandó azonban, hogy ezek a vizsgálatok többnyire a teljes Aid for Trade támogatást vették számba donortól függetlenül. Ugyan a táblázatban szereplő tanulmányok között található egy vegyes eredménnyel záruló elemzés (Udvari 2011b), ezt azonban nem tekinthetjük ellentmondásnak az előzőekkel leírtakkal. Ennek oka, hogy a tanulmányban szereplő statisztikai elemzés során a szerző azt vizsgálta, hogy a legkevésbé fejlett országok számítanak-e az Aid for Trade-támogatások elsődleges recipienseinek. Ahogyan később még részletesebben kifejtjük, a többváltozós statisztikai adatelemzés eredményei szerint nem kizárólag a legelmaradottabb országok a fő célcsoport.

\footnotetext{
${ }^{61}$ Az adathiányosság problémájára a dolgozat 5.4. fejezetében még visszatérünk az Aid for Trade hatásainak empirikus elemzése kapcsán.
} 
3.7. táblázat Az Aid for Trade megítélése a vonatkozó elemzésekben

\begin{tabular}{lcc}
\hline Tanulmány & Vizsgálat tárgya (donor) & Eredmény \\
\hline Helble et al (2009) & Export (általános) & ++ \\
\hline Huchot-Bourdon et al (2009) & Fejlödő országok tipizálása & n.a. \\
\hline Bearce et al (2010) & Export (USA) & ++ \\
\hline Moreira $(2010)$ & Export (általános) & ++ \\
\hline Naito $(2010)$ & Költségek (általános) & ++ \\
\hline Vijil és Wagner $(2010)$ & Export (általános) & ++ \\
\hline Cali és te Velde $(2011)$ & $\begin{array}{c}\text { Kereskedelmi költségek, } \\
\text { export (általános) }\end{array}$ & ++ \\
\hline Pettersson és Johansson (2011) & Export (általános) & + \\
\hline Udvari $(2011 b)$ & Legkevésbé fejlett országok & (általános) \\
\hline
\end{tabular}

Megjegyzés: ++: egyértelműen pozitív végeredmény, +: pozitív, de nem jelentős hatás, +/-: vegyes végeredmény; n.a.: nem hatásvizsgálat volt a tanulmány célja.

Forrás: saját szerkesztés

Az áttekintett kutatások közül Cali és te Velde (2011) adnak átfogó elemzést a program lehetséges következményeként fellépő exportvolumen változásáról: 130 fejlődő országra vonatkozóan vizsgálták a kereskedelmi költségek alakulását a 2005-2009-es periódusban, illetve az exportváltozást 100 fejlődő ország bevonásával 2002 és 2007 között. Ökonometriai modellek alkalmazásával kimutatták, hogy az AfT a kereskedelmi költségek csökkenéséhez vezet, valamint a gazdasági infrastruktúra fejlesztésére fordított összegek hozzájárulnak az export növekedéséhez. Ezzel szemben a termelő kapacitás fejlesztése nem jelent szignifikáns hatást az export bővülését illetően. Ehhez hasonló eredményre jutott Pettersson és Johansson (2011) is, viszont az Aid for Trade-nek összességében nem tulajdonítanak olyan nagy jelentőséget. A szerzők empirikus vizsgálatának eredményei alapján a kereskedelemhez kötődő segélyezést illetően a kereskedelmi infrastruktúra fejlesztésére érkező támogatásoknak van a legnagyobb hatása, ahogyan arra a Cali és te Velde (2011) szerzőpáros is jutott. Ezekkel ellentétben Helble és szerzőtársai (2009) már a kereskedelempolitika területére érkező támogatások hatásait is szignifikánsnak találták: gravitációs modell alapján készült elemzésük eredményei szerint a kereskedelempolitika területére érkező támogatások egyszázalékos növekedése (ami nagyjából 11,7 millió dollárnak felel meg) 818 millió dolláros kereskedelmi bővülést eredményez világszinten.

Vijil és Wagner (2010) szintén az AfT exportbővülésre gyakorolt hatását elemezte, viszont ök az infrastruktúra oldaláról közelítették meg a kérdést. Eredményeik szerint a kereskedelmi infrastruktúra fejlesztésére nyújtott támogatás 10 százalékos bővülése 1,22 százalékkal növeli a fogadó ország exportját. Mindez a partnerországok közötti vám- és 
nem vámjellegü akadály 2,3 százalékos csökkenésével egyenlő. Így a szerzők úgy vélik, hogy az AfT egyértelmủen pozitív hatással bír a fogadó ország exportjára nézve. Az eddigiektől némileg eltér Bearce és szerzőtársai (2010) munkája, hiszen ők konkrét donor, nevezeten az Amerikai Egyesült Államok AfT-tevékenységét elemezte az 1999-2008 közötti időszakban, vizsgálatuk középpontjában a fogadó országok exportjának bővülése áll. Eredményeik szerint a teljes AfT egydolláros emelkedése két évvel később 65 dolláros exportbővülést eredményez a fogadó országban, viszont a hatás a rászoruló (szegényebb, szárazfölddel elzárt) országokban nagyobb lehet. Figyelemre méltó azonban a szerzők által elemzett időszak: ennek alapján arra lehet következtetni, hogy az Aid for Trade lényegében a korábbi segélyezési gyakorlat követése, mindössze „új nevet adtak” az erre a területre irányuló fejlesztési támogatásoknak.

Mindezek mellett az AfT és a kereskedelmi költségek, illetve a gazdasági növekedés alakulása közötti kapcsolat vizsgálata jelenik meg Naito (2010) elemzésében. A tanulmány eredményei szerint az AfT hatására a szállítási költségek csökkennek, viszont a globális gazdasági növekedés - a donorországok csökkenő potenciálja miatt - nem minden esetben bizonyított. Moreira (2010) karibi országokra vonatkozó vizsgálatai alapján ezen országok nemzetközi kereskedelmi részvétele a rossz infrastruktúra, valamint a kedvezőtlen intézményi háttér miatt annyira alacsony szintű. A szerző eredményei szerint az AfT, ha jól célzott a felhasználása, hasznos lesz a régió országai számára a hosszú távú növekedési lehetőségeket illetően. Azonban a szerző azt is megjegyzi, hogy kiegészítő reformokra (például munkapiaci rugalmasság fejlesztése, jobb kormányzás, hatékonyabb szabályozási környezet) van szükség a kereskedelmi reformok végrehajtása előtt. Azaz itt is megjelenik az intézményi háttér fontossága.

Ahogyan azt már korábban kiemeltük, az Aid for Trade célkitüzései alapján a legkevésbé fejlett országok az elsődleges célcsoportja ezen segélyeknek. Ennek ellenére empirikus vizsgálatok azt mutatják, hogy összességében ez nem valósul meg (Udvari 2011b). 79 ország vizsgálata alapján egyes legkevésbé fejlett országok valóban kiemelkednek a kapott támogatást illetően, azonban hasonló számú olyan elmaradott ország is van, melyek teljesen másképp viselkednek, és nem igazán preferálják őket a donorok. Mindez pedig arra utal, hogy bár vannak hangzatos célkitüzések, mégis a segélyek pénzügyi jellege, valamint a donorok különböző (politikai-gazdasági) érdeke sokszor nagyobb szerepet játszanak az AfT-segélyek szétosztását illetően. Például Irak és Afganisztán is a jelentős recipiensek között található, illetve a legkevésbé fejlett országok esetében a szabadság indexe (Freedom House 
indikátora) és a támogatások nagysága között statisztikailag szignifikáns kapcsolat található, mely szerint a magasabb szabadsági fokkal rendelkező ország magasabb támogatáshoz jut.

Az előzőekben bemutatott kutatásokhoz képest Huchot-Bourdon és szerzőtársai (2009) teljesen más megközelítésben dolgoztak, nem a hatások elemzése volt a céljuk. A szerzők ugyan a kereskedelem, FDI és fejlődés közötti kapcsolatot vizsgálták, és elemzésükben a fejlődő országok tipizálását végezték el az Aid for Trade vonatkozásában, mellyel céljuk egyrészt az volt, hogy a fejlődő országok eltérő igényeikre rámutassanak, másrészt pedig az, hogy a fogadó országok prioritásait (szektorális igényeit) meghatározzák, ezzel is segítve a donorok döntését a segélyallokáció során. Későbbi, az Európai Uniót mint donort elemző empirikus vizsgálatunk tekintetében fontos eredmény, hogy a kereskedelemmel kapcsolatos igények Nyugat- és Kelet-Afrikában jelentősek, különösen az infrastruktúra fejlesztését illetően. Továbbá a szerzők arra is felhívják a figyelmet, hogy a kereskedelmi liberalizáció önmagában nem fogja javítani az FDI földrajzi eloszlását, hiszen ahhoz sok más tényezőnek kell meglennie úgy, mint politikai stabilitás, üzleti környezet, fizikai infrastruktúra, intézmény, humán tőke. Mindezzel pedig e szerzők is az intézményi háttér minőségét emelik ki.

A dolgozat ezen fejezete alapján több tanulságot is levonhatunk. Ugyan a kutatók körében még ma is jelentős vita van a nemzetközi kereskedelemben való részvétel, az exportbővülés lehetséges hatásait, következményeit, a segélyek és a kereskedelem közötti kapcsolatot, az Aid for Trade egyes részterületeinek kereskedelembővítő hatásait illetően, a nemzetközi szervezetek számos hivatalos dokumentumban nyíltan megfogalmazzák azt, hogy a nemzetközi kereskedelemben való részvétel a gazdasági fejlődéshez járulhat hozzá (a gazdasági növekedés mellett). ${ }^{62}$ Viszont az empirikus kutatások alapján e folyamatban az intézményi fejlettségnek kiemelkedő szerepe van. A hazai és nemzetközi szakirodalom széles körü áttekintése után azt tapasztaltuk, hogy az Európai Unió mint a világ legnagyobb donorának $^{63}$ és kereskedelmi preferenciákat nyújtó gazdaságának vizsgálata nincs a középpontban. Így a következőkben a dolgozat eddigi fejezeteiben levont tanulságok alapján az Európai Unió fejlesztési politikájának eredményeit értékeljük.

\footnotetext{
${ }^{62}$ Ugyan a nemzetközi szervezetek hivatalos dokumentumai alapján szegénység csökkenése is az eredmények között szerepel, a későbbiekben ezt mellőzzük.

${ }^{63}$ 2010-ben az EU 53,8 milliárd euró támogatást nyújtott, ami a világ teljes feljesztési támogatásának több mint fele (EC 2011d).
} 


\section{AZ EURÓPAI UNIÓ FEJLESZTÉSI POLITIKÁJA AZ EZREDFORDULÓIG}

A dolgozat ezen fejezetében az Európai Unió fejlesztési politikáját tekintjük át. Az Európai Unió a dolgozat témája szempontjából azért is kiemelkedően fontos, mert fejlesztési politikája részeként már évtizedek óta kereskedelmi kedvezményeket biztosít a fejlődő országoknak. Mindemellett az EU a világ legnagyobb donorja, és bár nem tartozik elsődleges céljai közé, mégis kiemelt figyelmet fordít a fejlődő országokkal ápolt kapcsolatra. A Maastrichti Szerződés óta pedig a fejlesztési együttmüködés közösségi politikaként jelenik meg. A legszorosabb és legátfogóbb gazdasági kapcsolata az afrikai, karibi és csendes-óceáni $\left(\mathrm{ACP}^{64}\right)$ országokkal alakult ki, így vizsgálódásunk középpontjában ezek az országok szerepelnek.

Az EU-s fejlesztési politika iránya témánk szempontjából két időszakra osztható: az ezredforduló előtti és az azt követő időszakra. Az ezredforduló előtt a viszonosság nélküli kereskedelmi kedvezmények játszották a legnagyobb szerepet az ACP-országok vonatkozásában, míg az ezredforduló után ez megváltozott a Kereskedelmi Világszervezet döntései és kötelezettségei, a nemzetközi közösség nyomása miatt. Továbbá, az ezredforduló után jelent meg az Aid for Trade, mellyel az EU akár javíthatja is a fejlesztési tevékenységét. Ezek miatt indokolt, hogy az Európai Unió fejlesztési politikáját ennek alapján két időszakra osszuk.

A dolgozat ezen fejezetében így az ezredforduló előtti időszakot tekintjük át, elsőként az EU-s fejlesztési politika sajátosságaira kitérve. Ezután a dolgozat szempontjából kiemelt jelentőséggel bíró Loméi Egyezmények hatásmechanizmusait részletezzük, majd az első empirikus vizsgálatunk eredményeinek bemutatására térünk rá a Loméi Egyezmények lehetségeses hatásait vizsgáltuk. A fejezet végén az eredmények mögött meghúzódó tényezőket igyekszünk feltárni.

\subsection{Az EU FEJLESZTÉSI POLITIKÁJÁNAK SAJÁTOSSÁGAI}

Az Európai Unió ugyan a külső kapcsolatokra és a fejlesztésre is kiemelt figyelmet fordít, az európai fejlesztési politika kutatása mégis háttérbe szorul (Arts és Dickson 2004), így ez még inkább indokolja az EU tevékenységének mélyebb megismerését. Bár az Európai

\footnotetext{
${ }^{64}$ African, Caribbean, Pacific countries. Szokás AKCS-államoknak is rövidíteni, a dolgozatban viszont inkább az eredeti (talán elterjedtebb) ACP mozaikszót használjuk.
} 
Unió és annak jogelődjei széles kapcsolat kiépítésére törekszenek a fejlődő országokkal ${ }^{65}$, a fejlesztési politika explicit módon csak az 1992-es Maastrichti Szerződésben jelent meg (Kiss 2007a, Mogliorisi et al 2003) - fejlesztési együttmüködés cím alatt. ${ }^{66}$ A szerződés hármas célt fogalmazott meg a fejlődő országokat érintő tevékenységével kapcsolatban (EC 2006a): (i) fenntartható gazdasági és társadalmi fejlődés, (ii) fokozatos világgazdasági reintegráció és (iii) szegénység elleni küzdelem. A 2009 decemberében hatályba lépett módosító Lisszaboni Szerződésben viszont ezek közül már csak a szegénység csökkentése és felszámolása szerepel célként (EC 2008c). Fontos hangsúlyozni, hogy a Lisszaboni Szerződés mindössze kiegészítő jelleget szán a közösségi fejlesztési politikának, így az EU fejlesztési politikája a közösségi és a tagállami fejlesztési tevékenységek együtteseként értelmezhető: a segélyek háromnegyede származik a tagállamoktól, míg egynegyede közösségi szintű támogatás (Montes és Migliorisi 2004, Morgera és Durán 2004, Paragi et al 2007). Lényegében ennek az egyesítésnek köszönhető, hogy az Európai Unió ma a világ legnagyobb segélynyújtója.

Az Európai Unió átfogó látáskörét (horizontális szemléletét) mutatja, hogy fejlesztési politikájának a hatékony segélyezés érdekében meg kell felelnie a 3C (3K) elvének, mely elvek a Maastrichti Szerződésben is megjelentek (Lightfoot 2010, O’Neill 2005, Szent-Iványi 2009b):

- koherencia, azaz annak biztosítása, hogy a tagállamok által folytatott más politikák nincsenek ellentétben a fejlesztési politika céljaival;

- komplementaritás, azaz az EU és a tagországok egymás tevékenységeit kiegészítik, közöttük munkamegosztás van; illetve

- koordináció, mely alapján az EU és a tagországok közötti konzultáció és információcsere biztosított.

Ezen elvek mellett Horváth (2005) még két fontos elvet említ meg. Egyrészt a politikai feltétel elve szerint a fejlesztési politika kedvezményezettjének demokratikus politikai berendezkedéssel kell rendelkeznie. A földrajzi súlyozás elve a nevével ellentétben nem a földrajzi adottságokat tekinti prioritásnak, hanem a legelmaradottabb országoknak prioritást kell élvezniük a fejlesztési politika kedvezményezettjeinek megállapítása során. Ha hozzátesszük, hogy a legkevésbé fejlett országok többsége Afrikában található (ahogyan ezt a dolgozat 2.1. fejezetében részleteztük), így érthető a megfogalmazás.

\footnotetext{
${ }^{65}$ A dolgozatban nem térünk ki az EU-s fejlesztési politika fejlődésére, kizárólag a megértéshez szükséges mértékben ismertetünk néhány tényt. A kialakulás részletes bemutatása megtalálható például Dezséri (2003) tanulmányában.

${ }^{66}$ A dolgozat egészében a fejlesztési politika és a fejlesztési együttműködés kifejezéseket szinonimaként használjuk.
} 
A dolgozat témája szempontjából kiemelten fontos a Lisszaboni Szerződés 210. cikke, amely alapvetően a komplementaritás elvét fogalmazza meg (EC 2008c, 115. o.): „Tevékenységeik egymást kiegészitő jellegének és eredményességének előmozditása érdekében az Unió és a tagállamok - nemzetközi szervezetek és nemzetközi konferenciák keretében is - összehangolják a fejlesztési együttmüködésre irányuló politikáikat, és konzultálnak egymással segélyprogramjaikról. Együttesen is felléphetnek. A tagállamok szükség szerint hozzájárulnak az uniós segélyprogramok végrehajtásához.” A harmonizáció felé haladást igazolja az is, hogy közösségi szinten, általánosan határoznak meg célszámokat arra vonatkozóan, hogy a tagországoknak bruttó nemzeti jövedelmük hány százalékát kell segélyezésre fordítani. A 2002-es, a fejlesztés finanszírozásáról szóló Monterrey konferencia után az EU az alábbi kötelezettségvállalásokat tette a Millenniumi Fejlesztési Célok megvalósítása érdekében (EC 2005a, Lightfoot 2008, UN 2008):

- A közösség összességében 2010-re a közösségi GNI 0,56 százalékát fordítja majd segélyezésre, ami 2015-re 0,7 százalékra növekszik a nemzetközi elvárásoknak megfelelően.

- A 2002 után csatlakozott államoknak GNI-arányosan 0,17 százalék a cél 2010-re, és 0,33 százalék 2015-re.

- Azon régi tagállamok, melyek nem érik el a segélyezést illetően a GNI 0,51 százalékát, 2010-ig erre a szintre, 2015-ig pedig 0,7 százalékra növelik. ${ }^{67}$

Annak ellenére, hogy időközben komoly pénzügyi és gazdasági válság alakult ki az Európai Unióban is, az EU 2009-ben megerösítette, hogy tartja magát ezekhez a célszámokhoz (EC 2009a), azonban az új tagállamokat illetően egyenként (lásd például Kiss 2007b), illetve összességében is kérdéses (irreleváns) a célszámok teljesítése (Lightfoot 2008). Azonban ezek a törekvések lehetővé teszik azt, hogy a tagállami fejlesztési politikákat is figyelembe vegyük az EU tevékenységének elemzése során.

Az Európai Unió fejlesztési politikájának eszközrendszere sokszínü, ami annak is betudható, hogy a fejlődő országokkal kialakított kapcsolatrendszer az Európai Unió mélyülésével beépült más szakpolitikákba is, köztük a kereskedelempolitikába (Kiss 2007a). Ennek következtében a lefektetett célokkal tulajdonképpen összhangban van, viszont más ország, gazdaság fejlesztési tevékenységéhez viszonyítva az EU fejlesztési politikája rendkívül egyedi képet mutat. Egyedi, mert fejlesztési tevékenysége a legtöbb nemzetközi

\footnotetext{
${ }^{67}$ Az OECD adatai alapján a 0,7 százalékos határértéket mindössze Svédország, Luxemburg és Dánia, valamint a nem EU-tag Norvégia teljesítik jelenleg. Magyarország 0,09 százalékos aránnyal rendelkezik (OECD CRS 2011).
} 
szervezettel, donorországgal ellentétben nem kizárólag pénzügyi támogatásokra (segélyek, kedvezményes hitelek, adósság-elengedés) épül, hanem különböző mértékü - szerződésben rögzített - kereskedelmi preferenciákat is biztosít a legtöbb fejlődő országnak (4.1. táblázat), ezzel pedig a közösségi kereskedelempolitikának kiemelt hatása van a közösségi fejlesztési politika alakulására. ${ }^{68}$ A fejlesztési támogatások (pénzügyi eszközök) alapján napjainkban az EU a legnagyobb donorszervezetnek számít (EC 2011a).

\section{1. táblázat Az EU fejlesztési politikájának eszközrendszere}

\begin{tabular}{cc}
\hline Pénzügyi eszközök & Kereskedelempolitikai eszközök \\
\hline Költségvetési forrás & Autonóm kereskedelmi preferenciák (GSP, GSP+) \\
Kedvezményes hitelek (Európai Beruházási Bank) & Szerződéses kereskedelmi preferenciák \\
Európai Fejlesztési Alap támogatásai & (bilaterális, multilaterális) \\
Gazdaságstabilizációs segélyek & Gazdasági Partnerségi Egyezmények (EPA) \\
(Stabex, Sysmin) & Fegyverek kivételével mindent (EBA) \\
& Dohai Fejlesztési Forduló
\end{tabular}

Aid for Trade kezdeményezés

Forrás: saját szerkesztés Dezséri (2003), Horváth (2005) és Udvari (2010c) alapján

Ami pedig a kereskedelempolitikai eszközöket illeti: a kereskedelmi preferenciák már régóta jelen vannak az EU külső tevékenységében (Dezséri 2003, Faber és Orbie 2008, Horváth 2005), azonban ez az elmúlt fél évszázadban a külső környezet változásának, a nemzetközi közösség nyomásának hatására jelentős változásokon ment keresztül (Faber és Orbie 2008). Ennek ellenére ma már az EU is nyíltan elismeri, hogy a kereskedelmi preferenciákat is a fejlesztési tevékenysége részének tekinti ${ }^{70}$ (EC 2006b, EC 2008a). Mivel a dolgozat empirikus részeiben az EU és a különböző országok közötti kapcsolatokat is figyelembe vesszük, fontos a különféle kapcsolattípusok relatíve részletes megismerése, melyekkel egyben a 4.1. táblázatban bemutatott kereskedelempolitikai eszközök egy részére is kitérünk, viszont a dolgozat következö fejezetében részletezzük.

Az Európai Unió - saját gazdasági érdekeit is figyelembe véve - különböző szintü kereskedelmi preferenciákat biztosít a fejlődő országok többségének, mely alapján meghatározható az ún. preferencia-piramis (4.1. ábra). E piramis tetején az afrikai, karibi, csendes-óceáni, az ún. ACP-országok állnak, ugyanis ezek az államok kapják a legnagyobb és legtöbb biztonságot nyújtó kedvezményeket és pénzügyi támogatásokat (Babarinde és Faber 2004, Balázs 2002, Persson és Wilhelmsson 2006), azaz ezek az országok tekinthetők az EU fejlesztési politikájának legfőbb kedvezményezettjeinek. Az EU-ACP-kapcsolatok

\footnotetext{
${ }^{68}$ Fontos megjegyezni azt, hogy más fejlett országok, mint például az USA, szintén kötöttek kedvezményes megállapodásokat Fekete-Afrika országaival. Ezek a dolgozat célja szempontjából nem relevánsak, de lásd részletesen például Phelps et al (2009) tanulmányát, vagy Elliott (2011) kritikáját az USA szerepéröl.

${ }^{69}$ Az EU-nak kiemelkedő szerepe van abban, hogy a Dohai Forduló központi eleme a fejlesztés is (EC 2005b).

${ }^{70}$ Erről a dolgozat következő fejezetében részletesebben szólunk.
} 
multilaterális szerződésekre épülnek (úgy, mint a Loméi Egyezmények, illetve a Cotonou-i Partnerségi Egyezmény), ami a szerződés jellege miatt biztonságot nyújt a szerződő feleknek, emellett pedig az egyezmények által biztosított preferenciák a termékek széles skáláját lefedik, és csak néhány kivétel található (Persson és Wilhelmsson 2006). Ma 79 ország tartozik az ACP-országok csoportjába (ACPSec 2011), közülük 48 az afrikai kontinensen található. Mindez előrejelzi azt, hogy az ACP-országokat nem szabad homogén csoportnak tekinteni, hiszen már maguk az afrikai országok is heterogének (lásd Collier et al (1997) tanulmányát is).

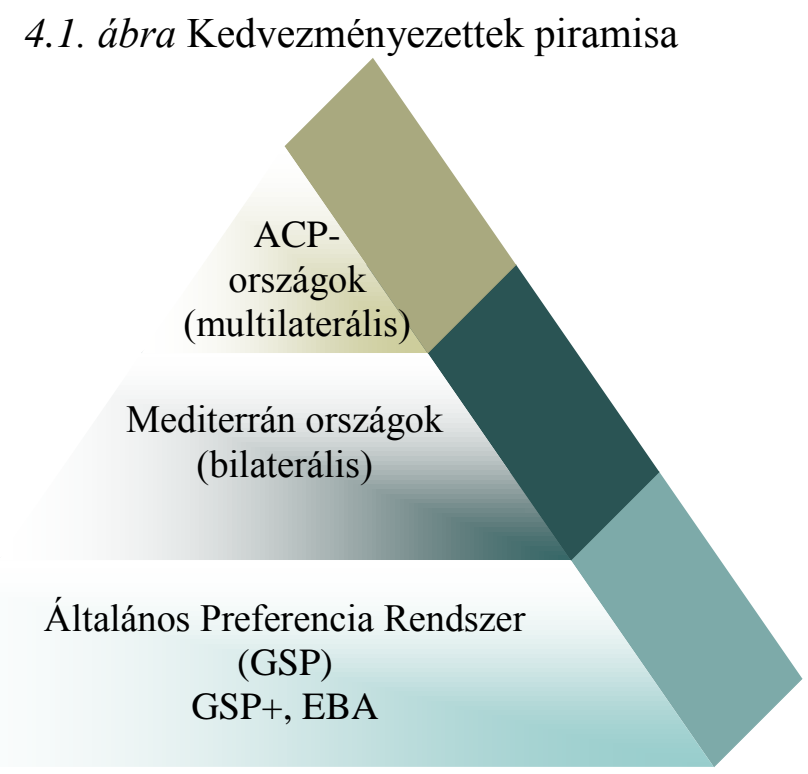

Forrás: saját szerkesztés Persson és Wilhelmsson (2006) alapján

A piramis középső szintjén a mediterrán országok állnak. Ezek az országok az ACPországokhoz hasonló kedvezményeket élvezhetnek, viszont velük az EU többnyire bilaterális szerződéseket kötött, valamint sokkal több kivétel és szigorúbb szabályozás jelenik meg ezen országokra vonatkozóan, mint az ACP-országok esetében (Persson és Wilhelmsshon 2006). Napjainkban 16 ország említhető meg a mediterrán országok között, melyekkel az unió az Euro-Mediterrán Partnerséget 2008-ban újraindította (EC 2011c).

A piramis legalján azok az országok találhatók, melyek kizárólag a GSP-rendszeren belül részesülnek kedvezményben. A GSP tekinthető a legrégebbi eszköznek a kereskedelmi preferenciák tekintetében: az Európai Közösség már 1971-ben kialakította GSP-rendszerét, és a latin-amerikai és ázsiai országok számára ez jelentős mértékű előnyt jelentett az ipari országokkal szemben (Faber és Orbie 2008, Nilsson 2011). A GSP keretein belül az érzékeny termékek (mezőgazdasági, ruházati áruk) esetében vámcsökkentések, míg a nem érzékeny 
termékek esetében vámmentesség van életben (Nilsson 2011). Összességében a GSP adta lehetőségek jelentik a legkevesebb kedvezményt a fejlődő országok számára: az EU autonóm módon - rendelettel szabályozva - nyújtja ezen kedvezményeket, ezáltal bármikor visszavonhatja, számos korlátozás van, a származási ország elve meglehetősen szigorú, valamint a rendszeren belül sok a kivétel (Horváth 2005, Nilsson 2011, Persson és Wilhelmsson 2006), ami a másik két országcsoportnál nem jelent meg. A kedvezmények visszavonása pedig megtörténik abban az esetben, ha az ország súlyosan megsérti valamely munkajogi vagy emberi jogi egyezményt ${ }^{71}$ (Nilsson 2011). Napjainkban az EU a legtöbb fejlődő országnak biztosít valamilyen kedvezményt a GSP alapján: 176 országot $^{72}$ takar és 6200-nál valamivel több terméket érint (Nilsson 2011).

Meg kell említenünk, hogy a GSP mellett ma már létezik az ún. GSP Plus (GSP+) is, melynek keretein belül az EU további engedményeket, vámmentes piacra lépést biztosít azon sérülékeny országok számára, melyek emberi jogokkal, munkajogokkal, környezetvédelemmel és jó kormányzással kapcsolatos nemzetközi egyezményeket írtak alá (EC 2008d, EC 2011b). Jelenleg 15 ország részesül a GSP+ kedvezményeiből (Nilsson 2011). ${ }^{73}$ Azonban a GSP és a GSP+ rendszerét egyaránt számos kritika éri (például a kedvezményezett országok kereskedelmi szerepe, a GSP+ által adott minimális kedvezmények a GSP-hez képest), melynek következtében 2014-től (a jelenlegi rendelet 2013 végi lejárta után) módosítások várhatók - már a jogosult országok meghatározásában is (Nilsson 2011).

Ezek alapján az Európai Unió szinte az összes fejlődő országgal ápol kapcsolatot, ami a kereskedelmi preferenciákon keresztül egyértelmüen nyomon követhető. Mindebből kifolyólag felmerül az a kérdés, hogy vajon az ACP-országok számára nyújtott (legjelentősebb) kedvezmények mennyiben járultak hozzá ezen országok gazdasági fejlődéséhez, és hogyan változott relatív helyzetük a többi fejlődő országhoz képest, amelyek sokkal kevesebb preferenciában részesültek az Európai Unió részéről. A dolgozatban ezt a vonalat visszük tovább, és az elemzés alapját a Loméi Egyezmények jelentik, hiszen az ACPországok ennek keretében részesültek szerződéses keretek között kereskedelmi kedvezményben.

\footnotetext{
${ }^{71}$ Ilyen fordult elő például Fehéroroszország, illetve Burma esetében (Nilsson 2011).

${ }^{72}$ E szám is alátámasztja, hogy pontosan definiálni kell a fejlődő országok körét.

${ }^{73}$ A jelenlegi GSP-ről szóló rendelet szabályozza az Everything But Arms kezdeményezést is, erre azonban később, a dolgozat 5.2. fejezetében térünk ki.
} 


\subsection{A LOMÉI EGYEZMÉNYEK HATÁSMECHANIZMUSA ÉS KERESKEDELMI EREDMÉNYEI}

Ahogyan arra már az előző fejezetben utaltunk, az Európai Közösség már évtizedek óta alkalmazza a kereskedelempolitikai eszközöket fejlesztési tevékenysége céljainak elérése érdekében (Faber és Orbie 2008, Horváth 2005). A legnagyobb ilyen jellegú vállalkozásnak talán a Loméi Egyezmények tekinthetők, és ezek jelentik az Európai Unió és az ACPországok közötti együttmüködés alapját. ${ }^{74} 1975$ és 2000 között négy Loméi Egyezményt írtak alá, amelyek középpontjában a kereskedelmi preferenciák álltak: az EU szabad és viszonosság nélküli piacra lépést biztosított az aláíró ACP-országoknak az európai piacokra - az EU egyoldalú, öncélú változtatási lehetőségét kizáró - szerződéses formában (Abass 2004, Babarinde és Faber 2004, Cosgrove 1994, Whiteman 1998). A 25 évig érvényben lévő egyezmények miatt az egyik leghosszabb ideig fennálló és átfogó rendszer alakult ki az Észak-Dél közötti együttműködésben (Parfitt 1996). A kereskedelmi preferenciák mellett azonban egyéb gazdasági kedvezményekhez is hozzájutottak az ACPországok (Babarinde 1994, Parfitt 1996):

- Gazdaságstabilizációs rendszerek (Stabex, Sysmin) felállításán keresztül a mezőgazdasági és bányászati termékek exportjától függő országok csökkenő exportbevételeinek kezelése volt a cél, ami lehetőséget teremtett arra, hogy ne más területekről (infrastruktúra-, oktatásfejlesztés stb.) vonjanak el állami forrásokat (Spaventa 1999).

- Ipari együttmüködés címén az ACP-országok ipari és technikai fejlődése az elérendő cél, melynek során technológia-transzfer történik az EU és az ACP-országok között, vállalkozói együttmüködések alakulnak ki, valamint az ACP-országok ipari termékeinek exportja növekszik.

- Pénzügyi és technikai együttmüködés területén az ACP-országok gazdasági és társadalmi fejlődését, modernizációját, az ACP-országok közötti együttműködés fejlődését, valamint az ACP-országok gazdasági szerkezetének diverzifikációját határozták meg teljesítendő célként.

- Tőke szabad áramlásának biztosítása a partnerek között.

\footnotetext{
${ }^{74}$ Egyes szerzők (például Hinkle et al 2005) az ACP-országok kialakulását a Yaoundé Egyezményekhez köti, annak ellenére, hogy hivatalosan csak az 1975-ös Georgetowni Egyezmény hívta életre ezt a csoportot, illetve határozta meg, hogy mely országok lehetnek az ACP-csoport tagjai (EC-ACP 1975). A dolgozatban e tényből kifolyólag az ACP-országokat illetően kizárólag a Loméi Egyezményeket tárgyaljuk.
} 
E gazdasági beavatkozásoktól és a kereskedelmi lehetőségektől azt remélték, hogy az exportnövekedés és a gazdasági diverzifikáció hozzájárul a gazdasági növekedéshez és fejlődéshez az érintett ACP-országokban (4.2. ábra) (Babarinde 1994, Babarinde és Faber 2004, Kebonang 2007, Spaventa 1999), annak ellenére, hogy e tényezők között nem teljesen egyértelmü a kapcsolat megléte, ahogyan erre a dolgozat 3.2.3. fejezetében már utaltunk. Ezeket a folyamatokat pedig a tőkeáramlás és a pénzügyi támogatások is kiegészítik. Meg kell jegyezni, hogy jelen esetben a viszonosság nélküli kedvezmények azért is jelentősek, mert az afrikai országok legtöbbje az 1960-1980-as évek között importhelyettesítő politikát folytatott, erős kereskedelmi korlátozást biztosító kereskedelempolitikai eszközök alkalmazásával (UNCTAD 2008b).

4.2. ábra A Loméi Egyezmények lehetséges hatásai

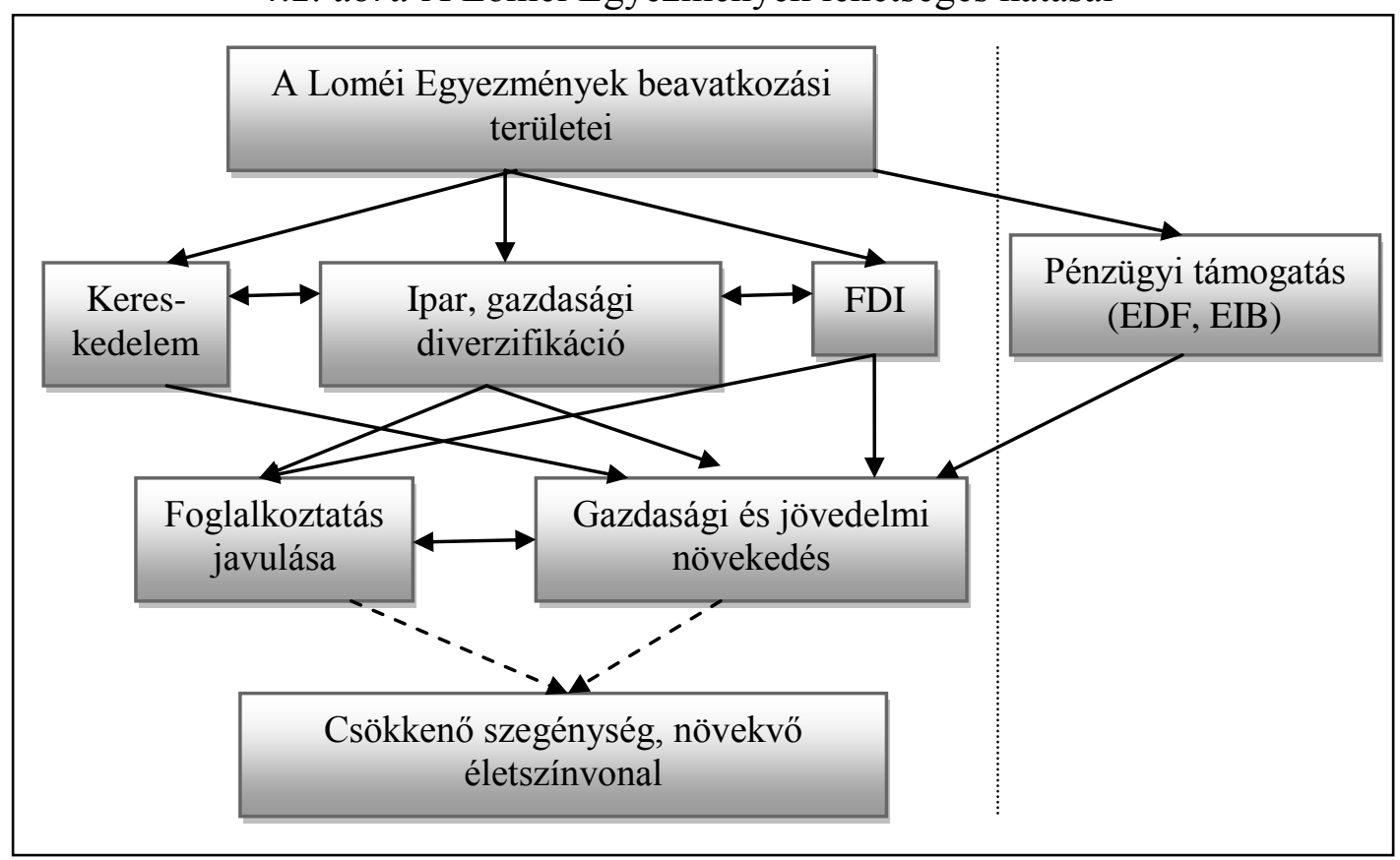

Forrás: saját szerkesztés Udvari (2010b), 81. o. alapján

A kereskedelmi kedvezmények a fentieken túl azért is jelentősek, mert a vámmentesség az ACP-országok exporttermékeinek több mint 90 százalékát érintette (Babarinde és Faber 2004), viszont kimaradt számos, az EU-s közös agrárpolitika szabályozása alá eső mezőgazdasági termék (Mahler 1994). Ezen kívül már az első Loméi Egyezményt aláíró 46 ACP-ország több mint fele - összesen 29 ország - a kereskedelmi akadályok lebontását célul kitüző GATT-nak is szerződő fele. Bár a szabad kereskedelemnek számos előnye van, az 1950-es évek óta (a kisebb-nagyobb mértékben) folyamatosan csökkenő vámok a fejlődő (köztük az ACP-) országokat hátrányosan érintette olyan szempontból, hogy a kedvezőbb feltételek ebben az időszakban elsősorban az ipari termékeket érintették (Somai 1997, Stiglitz 2003), és a fejlődő országok főként a nem ipari 
termékek kereskedelmére szakosodtak (ahogy erre a dolgozat 2.3. fejezetében már utaltunk). Emellett több - a fejlődő országok által is exportált - termék (például cipők, kézmüves áruk, mezőgazdasági termékek) esetében jelentős, nem vámjellegü korlátozásokat alkalmaztak (Somai 1997). Ebből következően ezek az országok hátrányba kerültek az általuk exportálni képes (mezőgazdasági és félkész-) termékeket érintő protekcionizmus miatt, és számukra kedvezőnek tünt a piacra lépés lehetősége az európai piacokra a Loméi Egyezmények adta kereteken belül.

Bár a Loméi Egyezményekkel foglalkozó szakirodalom többsége elsősorban a kereskedelem és a kereskedelmi preferenciák szerepét hangsúlyozza az egyezményekkel kapcsolatban, ezeket - véleményünk szerint - nem szabad kizárólag kereskedelmi megállapodásnak tekinteni. Az egyezmények ugyanis hangsúlyt helyeztek a gazdasági diverzifikációra is (lásd 4.2. ábra), és nem az egy termékre szakosodást támogatták. Mindez azért fontos, hiszen a gazdasági diverzifikáció szintén hozzájárulhat a gazdasági fejlődéshez, annak előzményének tekinthetjük (Zhang 2003). A gazdasági diverzifikáció megvalósításának lehetséges eszköze a beruházásokat, beruházókat vonzó ipari fejlesztés és technológiai együttmüködés (Zhang 2003), és ezek szerepelnek a Loméi Egyezményekben is. Mindennek végső célja az, hogy az ACP-országok elmaradott áruszerkezete fejlődjön, és több, versenyképesebbnek számító áruval lépjenek a nemzetközi piacra, így gazdasági kiszolgáltatottságuk csökkenne. Továbbá, a harmadik és negyedik egyezmény a mezőgazdaság fejlesztését is hangsúlyozza, szintén a magasabb szintü technológiai eszközök adaptálásával (EC 1986, 1991), annak érdekében, hogy javuljon az ágazat termelékenysége.

A Loméi Egyezmények lehetséges hatásaival kapcsolatban számos tanulmány született, viszont a gazdasági - köztük a kereskedelmi - következmények megítélése vegyes képet mutat. A közös pontnak tulajdonképpen az tekinthető, hogy a Loméi Egyezmények ugyan nem tekinthetők hatékonynak, viszont nélkülük a helyzet kedvezőtlenebb lenne (Babarinde és Faber 2004, Persson és Wilhelmsson 2006, Udvari 2010d). E tanulmányok, kutatások gyengesége, hogy elsősorban a kereskedelem alakulására terjedtek ki, illetve gyakoriak voltak az elméleti síkon folytatott fejtegetések, amelyeket kevés, vagy csak leíró statisztikával támasztották alá (például Babarinde és Faber 2004, Bjornskov és Krivonos 2001, Hurt 2003, Nunn és Price 2004). A következőkben az empirikus eredmények bemutatására helyezzük a hangsúlyt.

Persson és Wilhelmsson (2006) is a kereskedelmi kedvezmények hatásait elemezték a partnerek közötti kereskedelemre vonatkozóan: a tanulmányukban gravitációs modell 
segítségével 112, az EU-val több-kevesebb kapcsolattal rendelkező ország esetében vizsgálták a kereskedelem alakulását. Eredményeik szerint az ACP-országok, melyek a legnagyobb kedvezményben részesültek az EU-ból, részesedése ugyan csökkent az EU importjából, azonban ez az eredmény még rosszabb lenne, ha nem lettek volna ezek a kedvezmények.

A probléma azonban nem csak az, hogy a kereskedelem volumene nem nőtt a partnerek között, hanem az is, hogy nem lett diverzifikált sem, ahogyan erre Curran és szerzőtársai (2008) rámutatnak. Így véleményük szerint az exportvezérelt növekedés nem mutatja jeleit e fejlődő országokban. Mindeközben az afrikai országok EUkiszolgáltatottsága megmaradt, amely lehetőségeiket jelentős mértékben befolyásolja. Hinkle és Schiff (2004) mutatnak rá erre tanulmányukban: az EU a fekete-afrikai országok legjelentősebb kereskedelmi partnerévé vált, ezáltal pedig szignifikáns hatást gyakorol azok gazdasági fejlődésére.

A dolgozat 2.1. fejezetében mutattuk be a fejlödő országok heterogenitását, ami felveti azt a kérdést, hogy vajon a Loméi Egyezmények által biztosított kedvezményeknek volt-e valamilyen szerepük a fejlődő országok közötti konvergencia, illetve divergencia alakulásában. Gáspár és Udvari (2011) elemezték a konvergencia-folyamatokat, melynek eredményei, következtései Hinkle és Schiff (2004) megállapításával ellentétes, Curran és szerzőtársai (2008) állításaihoz pedig hasonlóak. A szerzők 140 fejlődő és tranzíciós ország bevonásával végezték el a szigma-, béta- és sztochasztikus konvergenciára vonatkozó vizsgálataikat, melyekhez a Loméi Egyezmények beavatkozási területei alapján kiválasztott indikátorok jelentették az alapot. Eredményeik szerint bár abszolút konvergencia nem, klub konvergencia valószínűleg bekövetkezett a vizsgálatban szereplő országok körében, összességében a Loméi Egyezmények szerepe nem mutatható ki a konvergenciafolyamatokban a vizsgált indikátorok alapján.

A kutatásunk során megismert tanulmányokból hiányoltuk a kedvezmények, a kereskedelmi beavatkozásnál tágabb értelemben vett intervenciók lehetséges hatásainak átfogóbb elemzését, a mélyebb statiszikai-ökonometriai adatelemzéssel alátámasztott kutatást, mellyel arra kaphattunk volna választ, hogy a nemzetközi kereskedelem, a kereskedelmi preferenciák és a szabad piacra lépés jelentett-e valódi pozitív gazdasági változásokat, amely jelen értekezés központi kérdése is. A beavatkozási területek, a hosszú távon (számos ország esetében 25 éven keresztül) biztosított kedvezmények - az elöző fejezetben bemutatott dilemmák ismerete ellenére - arra utalnak, hogy ez megfelelő alapot jelentett az aláíró fejlődő országok számára - más fejlődő országokhoz történő - felzárkózásuk megvalósításához. 
Ezért úgy gondoljuk, hogy érdemes a Loméi Egyezmények lehetséges hatásait empirikus úton is elemezni. Az említett hiány pótlása érdekében jelen dolgozatban a gazdasági oldal elemzésére törekszünk, melynek során figyelembe vesszük a Loméi Egyezmények általános (elméleti) hatásmechanizmusát (lásd 4.2. ábra), melyeket proxy (közelítő) mutatókkal igyekszünk számszerüsíteni. Célunk elérésének legjobb módját a Loméi Egyezményeket megelőző és követő időszak összehasonlításában láttuk. A vizsgálatunk során arra kerestük a választ, hogy az ACP-országok relatív helyzete hogyan változott a Loméi Egyezmények előtti időszakhoz képest annak lejárta után más fejlődő országokhoz viszonyítva. Ezzel a vizsgálattal a dolgozat bevezetőjében meghatározott 1. és 2 . hipotézisünkre igyekszünk választ kapni, melyeket szigorúan az előzőekben bemutatott elméleti feltevések - nem pedig az empirikus vizsgálatok eredményei - alapján fogalmaztunk meg. A könnyebb követhetőség érdekében a két hipotézis megismételve:

- 1. hipotézis: Az ACP-országoknak a Loméi Egyezmények beavatkozási területeihez köthető gazdasági teljesítménye a Lomé-rendszert követően kedvezőbb az egyezményeket alá nem író fejlődő országok gazdasági teljesítményéhez képest.

- 2. hipotézis: A Loméi Egyezmények beavatkozási területei alapján meghatározott gazdasági indikátorok figyelembe vételével a heterogén ACP-országok több, egymástól jól elkülöníthető, homogén csoportra bonthatóak.

\subsection{A LOMÉI EGYEZMÉNYEK TANULSÁGAI}

Mivel a négy Loméi Egyezmény alapvetően ugyanazokra a területekre koncentrált, következésképpen a legtöbb ACP-ország a kereskedelmi és egyéb gazdasági kedvezményeket 25 éven keresztül élvezhette, így lehetővé válik az egyezmények ACP-országok gazdaságára gyakorolt hatásának empirikus elemzése. A statisztikai elemzés az egyezményeket megelőző és követő időszak eredményeinek összehasonlításán alapul. Annak érdekében, hogy a legpontosabb eredményeket kapjuk, az ACP-csoporton kívüli fejlődő országokat is bevontunk a vizsgálatba, és ezen országok eredményéhez is viszonyítottuk az ACP-országok fejlődését. Az empirikus elemzés fókusza az elemzésben szereplő országok relatív helyzetének vizsgálata, az abban kimutatható változás megragadása.

\subsubsection{A VIZSGÁLT ORSZÁGOK KÖRE ÉS AZ INDIKÁTOROK}

Az empirikus elemzés alapját jelentő országok és indikátorok kiválasztása hosszú folyamat eredményeként és számos tényező átgondolása után jött létre (4.3. ábra). A mutatók 
és országok kiválasztása során két dolgot vettünk figyelembe: elsődlegesen a Loméi Egyezmények beavatkozási területeire koncentráltunk, másodlagosan pedig néhány releváns szakirodalomból ismert indikátort gondoltunk át. Az irodalmi áttekintés során nem kizárólag a Loméi Egyezmények empirikus vizsgálatával foglalkozó tanulmányokat néztük át, hanem figyelembe vettünk néhány más jellegü cikket is: a gazdasági növekedés, a fejlődés és a kereskedelem összefüggéseit vizsgáló (például UNCTAD 2007, Yanikkaya 2003), a gazdasági diverzifikációt számszerüsíteni próbáló (például Zhang 2003), valamint a versenyképesség elemzésével (például Lengyel 2000, Lukovics 2008) foglalkozó kutatásokat is. Mindemellett a dolgozat 2.2. fejezetében ismertetett gazdasági fejlödés jellemzőit is figyelembe vettük, akárcsak a 3.2.4. fejezetben szereplő TDI indexet és részindikátorait.

4.3. ábra Az országok és indikátorok kiválasztásának folyamata

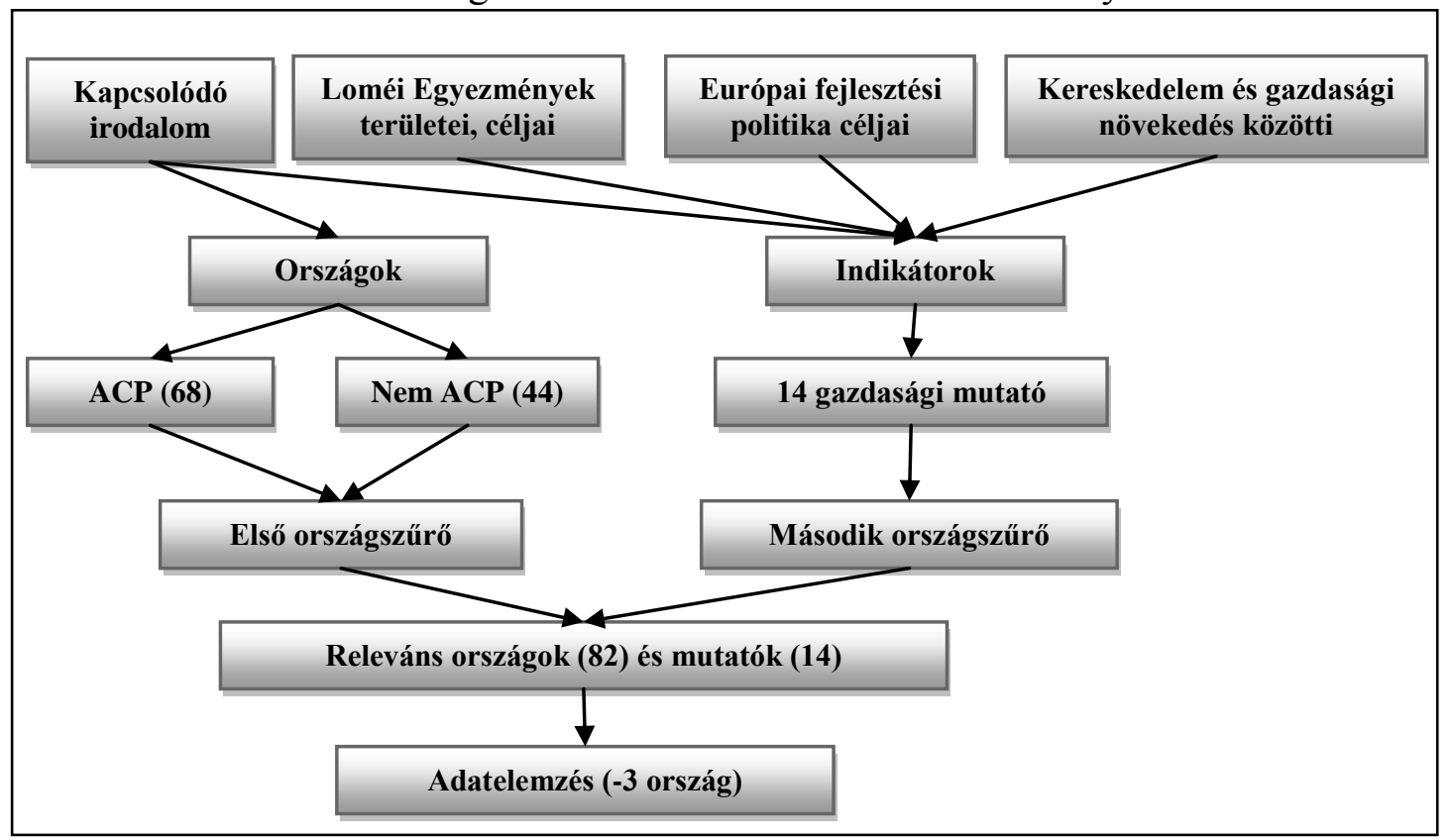

Forrás: saját szerkesztés

Először tekintsük át a vizsgálat mintájául szolgáló országok kiválasztásának folyamatát. A releváns országok meghatározása több kérdést is felvetett: csak az ACPországokat vonjuk be, vagy szerepeljenek más országok is a vizsgálatban? Ha más országok is szerepelnek, szelektálni kell közöttük, vagy törekedjünk a minél átfogóbb elemzésre? Végül az országok kiválasztása során elfogadtuk Babarinde és Faber (2004) és Persson és Wilhelmsson (2006) vizsgálati módszereit. A szerzők az ACP-országok teljesítményét ún. kontrollországokhoz viszonyították, hiszen feltételezéseik szerint a Loméi Egyezményekkel olyan többletkedvezményhez jutottak ezek az államok, amelyek következtében gazdasági eredményeiket tekintve látványosan el kellene különülniük a kontrollországoktól. Mindezek 
alapján vizsgálatunkba az ACP-országok mellett bevontuk a preferencia-piramis alapján a mediterrán partnerség országait is, valamint azokat az államokat, amelyek kizárólag a GSP rendszerén keresztül részesültek támogatásban az Európai Uniótól. A potenciális országok meghatározása során nagymértékben támaszkodtunk Persson és Wilhelmsson (2006) tanulmányára, melynek alapján az alapsokaság 112 országból állt, azonban az elemzési folyamat során néhány országot ki kellett hagynunk a vizsgálatból. Egyrészt kihagytuk Kínát és Indiát mint a világkereskedelem meghatározó (fejlődő) gazdaságait ${ }^{75}$, másrészt kiszürtük azokat az államokat, ahol valamely indikátor esetében nem állt rendelkezésre adat. Továbbá fontos hangsúlyozni, hogy Szingapúr, valamint Izrael bár hivatalosan nem fejlődő országok a dolgozat 2.1. fejezetében meghatározott definíció alapján, mégis bekerültek a vizsgálatba. Ennek oka, hogy Szingapúr 1972 és 1999 között részesült GSP-kedvezményben, Izrael pedig a Mediterrán Partnerség országai között található meg. Ennek eredményeképpen elsődleges vizsgálatunk 14 mutatón és 82 országon alapult, viszont ezt a későbbiekben a további outlierek miatt 79 országra le kellett szúkítenünk. Az országok közül elsődlegesen 51 tartozott az ACP-csoportba, a szükítés után 48 ország maradt ebben a körben, a többi 31 ACPn kívüli ország.

Az indikátorok meghatározása több kérdést vetett fel, és számos tényezőt át kellett gondolnunk, nem várt akadályokat áthidalnunk. Az első körben kiválasztott indikátorokat több okból szükítenünk kellett. Egyrészt a dolgozatban a Loméi Egyezmények közvetlen gazdasági hatásainak elemzését tekintjük elsődleges célnak, így vizsgálatunkba nem vontunk be társadalmi jellegű indikátorokat (például szegénység). Másrészt csak a közvetlen hatások alapján szerettünk volna következtetéseket levonni, így néhány - más empirikus elemzésben megjelenő - makrogazdasági mutatót elemzésünkből kihagytunk (például az árfolyam változását, az inflációt, az adósságállományt). Harmadrészt néhány indikátor nem volt elérhető az 1970-es évekre vonatkozóan, ilyen esetekben azokat igyekeztünk megközelítő (proxy) mutatókkal helyettesíteni. Továbbá csak statikus mutatókat vontunk be, hiszen „pillanatképeket” készítünk az országok teljesítményéről az indikátorok alapján, így a gazdasági növekedés indikátora, a GDP/fő növekedése mint dinamikus mutató ebbe nem fér bele. A szelekció után összesen 14 - kizárólag gazdasági jellegű - mutatót határoztunk meg, amelyeket alkalmasnak találtunk az egyezmények közvetlen hatásainak elemzésére (4.2. táblázat). A mutatók elemzéséhez szükséges adatokat az 1970-1975, valamint a 2000-2005 közötti évekre gyüjtöttük össze. Annak érdekében, hogy az esetleges kiugró (outlier), illetve

\footnotetext{
${ }^{75}$ Mivel a klaszterelemzés érzékeny a kiugró értékekre, ezek az országok viszont a kereskedelmet illetően kiugró értékekkel rendelkeznek, így ki kellett hagyni a vizsgálatból.
} 
extrém értékeket egy-egy ország esetében elkerüljük, ezekre az évekre átlagokat határoztunk meg.

4.2. táblázat A vizsgálatba bevont indikátorok köre

\begin{tabular}{|c|c|c|}
\hline Dimenzió & $\begin{array}{c}\text { Loméi Egyezmények } \\
\text { területe }\end{array}$ & Indikátorok (forrás) \\
\hline \multirow{3}{*}{ 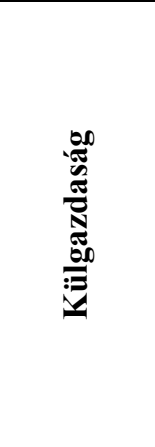 } & $\begin{array}{l}\text { EU-val való } \\
\text { kereskedelem }\end{array}$ & $\begin{array}{l}\text { az EU részesedése az ország exportjából (UNCTAD 2011) } \\
\text { az EU részesedése az ország importjából (UNCTAD 2011) } \\
\text { az ország részesedése az EU harmadik országokkal folytatott } \\
\text { exportjából (UNCTAD 2011) } \\
\text { az ország részesedése az EU harmadik országokkal folytatott } \\
\text { importjából (UNCTAD 2011) }\end{array}$ \\
\hline & Nyitottsági mutatók & $\begin{array}{l}\text { az export aránya a GDP-ben (UNCTAD 2011) } \\
\text { külkereskedelmi mérleg (UNCTAD 2011) }\end{array}$ \\
\hline & Külföldi tökebefektetés & $\begin{array}{l}\text { egy főre jutó beáramló közvetlen külföldi beruházás (UNCTAD } \\
\text { 2011) } \\
\text { a beáramló külföldi tőke aránya a GDP-ben (UNCTAD 2011) }\end{array}$ \\
\hline \multirow[t]{2}{*}{ 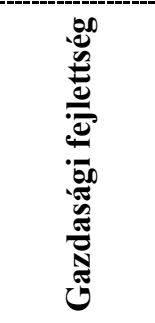 } & $\begin{array}{l}\text { Gazdasági } \\
\text { diverzifikáció, ipari } \\
\text { együttmüködés }\end{array}$ & $\begin{array}{l}\text { a mezőgazdaság hozzáadott értéke (UN 2011d) } \\
\text { az ipar hozzáadott értéke (a közmúvek kivételével) (UN 2011d) } \\
\text { a szolgáltatások hozzáadott értéke (UN 2011d) } \\
\text { a mezőgazdasági foglalkoztatottak aránya a teljes népességen belül } \\
\text { (UNCTAD 2011) } \\
\text { egy mezőgazdasági foglalkoztatottra jutó mezőgazdasági termelés } \\
\text { (mezőgazdasági termelékenység) (UNCTAD 2011) }\end{array}$ \\
\hline & Fejlettségi szint & egy főre jutó GDP (logaritmizált) (UNCTAD 2011) \\
\hline
\end{tabular}

Forrás: saját szerkesztés

A kereskedelmi teljesítmény számbavételét illetően szükséges a kereskedelmi tevékenység két oldalról történő vizsgálata: egyrészt elemeznünk kell, hogy az EU mennyire fontos partner az adott ország számára; másrészt azt is meg kell néznünk, hogy vajon az ország mennyire fontos kereskedelmi partner az EU számára. Valamint - ahogyan arra már utaltunk a dolgozat korábbi részeiben - az importnak is lehet jelentősége, így Karbasi és Tavana (2009) elemzésének eredményei alapján az export mellett az import alakulását is számba vettük, viszont a külkereskedelmi mérleg alakulását is figyelembe vettük. Az EU részesedését mutató indikátorok előzetes elemzése rávilágított arra, hogy az EU a vizsgált országok kereskedelmi tevékenységében jelentős szerepet játszik, ${ }^{76}$ így jogosan feltételezhető, hogy az EU beavatkozásának jelentős hatása lehet ezen országok gazdasági teljesítményére.

A vizsgálatba bevont indikátorok között a külkereskedelmi mérleg egyenlege szerepel, bár helyette elsődlegesen a folyó fizetési mérleg egyenlegét szerettük volna a vizsgálatunkban szerepeltetni, azonban az 1970-75 közötti időszakra hiányos adatok álltak rendelkezésre, melynek következtében jelentős mértékben csökkentenünk kellett volna a vizsgálatba bevont országok körét. Az UNCTAD adatbázisában a fizetési mérlegre vonatkozó adatok csak 1980-

\footnotetext{
${ }^{76}$ A mutató átlaga az exportrészesedést illetően 41,8 százalék, az importrészesedést illetően pedig 37,41 százalék a Loméi Egyezményeket megelöző időszakban.
} 
tól érhetők el, ami már az első Loméi Egyezmény utáni időszakra vonatkozik, így ezt nem tekinthetjük az időszak előtti eredménynek. Ennek elkerülése és egy egyensúlyi mutató bevonása érdekében szerepel a vizsgálatban szimplán a külkereskedelmi mérleg egyenlege. További pénzügyi jellegü indikátor bevonását (mint például a cserearány változása) szintén korlátozta az elérhető adatok időtávja. Az UNCTAD adatbázisa ez esetben is csak 1980-tól tartalmazott adatokat (és az időperiódus elején meglehetősen hiányos). A cserearány indikátorának bevonását végül azért sem tartottuk szükségesnek, hiszen a cserearány és a külkereskedelmi mérleg alakulása között pozitív kapcsolat mutatható ki (lásd például Otto (2003), vagy Senhadji (1998) tanulmányát), így többletinformációt nem hordozna, és a változók közötti multikollinearitás torzított eredményre vezethet. ${ }^{77}$

Ahogyan arra a 3.2.3. alfejezetben kitértünk, egyes kutatások szerint a kereskedelem a gazdaság diverzifikálódásában is szerepet játszhat, pozitívan hathat az ipari folyamatokra. Ennek következtében, valamint a Loméi Egyezmények területeinek ismeretében (ipari együttműködés, technológiai fejlesztés) a gazdasági diverzifikációra vonatkozó indikátort is be kellett vonnunk. Az indikátor meghatározásánál jelenetős segítséget jelentett az Economic Diversification Index (EDI) (Zhang 2003). Bár a komplex mutató értékei csak az 1990-es évek közepétől érhetők el, komponenseinek ismerete segítséget jelentett abban, hogy az ipari együttmüködés és a gazdasági diverzifikációra vonatkozóan megfelelő mutatókat határozzunk meg. Bár a mutató az ipari foglalkoztatottak arányát vizsgálja, esetünkben ez az indikátor nem állt rendelkezésünkre, így proxy-mutatóként a mezőgazdasági foglalkoztatottak arányát szerepeltetjük a vizsgálatban. Ez nem tekinthető problémának, hiszen az egyezményekben megjelent a mezőgazdasági fejlesztés is, így ennek mérésére is alkalmas ez az indikátor.

Az indikátorokat áttanulmányozva felmerülhet a kérdés, hogy mindezekben hol jelenik meg a Loméi Egyezményekkel járó kedvezmény, úgy mint a szabad piacra lépés, a pénzügyi támogatás, a kvótamentes piacra jutás. Ezek ugyan közvetten, de szerepelnek a fenti indikátorokban: a vám- és kvótamentes piacra lépés lehetősége - elvileg - növekvő exporttal kellene, hogy párosuljon, melynek eredményeként az EU szerepe a partnerországok kereskedelmében is növekszik. A pénzügyi támogatások, a gazdaságstabilizációs segélyek (Sysmin, Stabex) hatásának pedig a gazdasági diverzifikációban kellene megjelennie, a munkaerő gazdasági szerkezetenkénti megoszlásának változásában, a termelékenység javulásában. Mindezek közvetlen számszerüsítésére nem tettünk kísérletet, hiszen elsődleges

\footnotetext{
${ }^{77}$ Az elérhető adatok alapján a saját mintánkra vonatkozóan is elvégeztük a korreláció-számítást: szignifikáns, pozitív korreláció mutatható ki a külkereskedelmi mérleg egyenlege és a cserearány mutató között.
} 
célunk annak elemzése, hogy a Loméi Egyezmények beavatkozási területeihez köthető gazdasági teljesítmény alapján a vizsgálatban szereplő országok hogyan helyezkednek el egymáshoz képest.

A Loméi Egyezmények eredményességét több tényező is befolyásolhatja, befolyásolhatta (4.4. ábra). ${ }^{78}$ Ezen tényezőket proxy mutatókkal lehetne számszerűsíteni, viszont fö célunk az adott körülmények között bekövetkező változások kimutatása, így kizárólag az ábrán szereplő „,mag” területtel foglalkoztunk. Az ún. befolyásoló tényezőket mindössze az egyes csoportok jellemzésére használjuk, arra keresve a választ, hogy valóban van-e összefüggés az intézményi háttér minősége és a gazdasági teljesítmény között, hiszen a dolgozatban több korábbi elemzés kapcsán kiemeltük, hogy az intézményeknek fontos szerepe lehet ezekben a folyamatokban (is). Az intézményi minőséget jelző indikátorokat azért nem vontuk bele a klaszterelemzéshez felhasznált indikátorok körébe, mert egyrészt nem kapcsolódnak a Loméi Egyezmények hatásaihoz, másrészt néhány ország esetében nem volt elérhető adat (az elemzés során ezt jelezzük).

\section{4. ábra A Loméi Egyezmények elméleti hatásmechanizmusa és a befolyásoló tényezők}

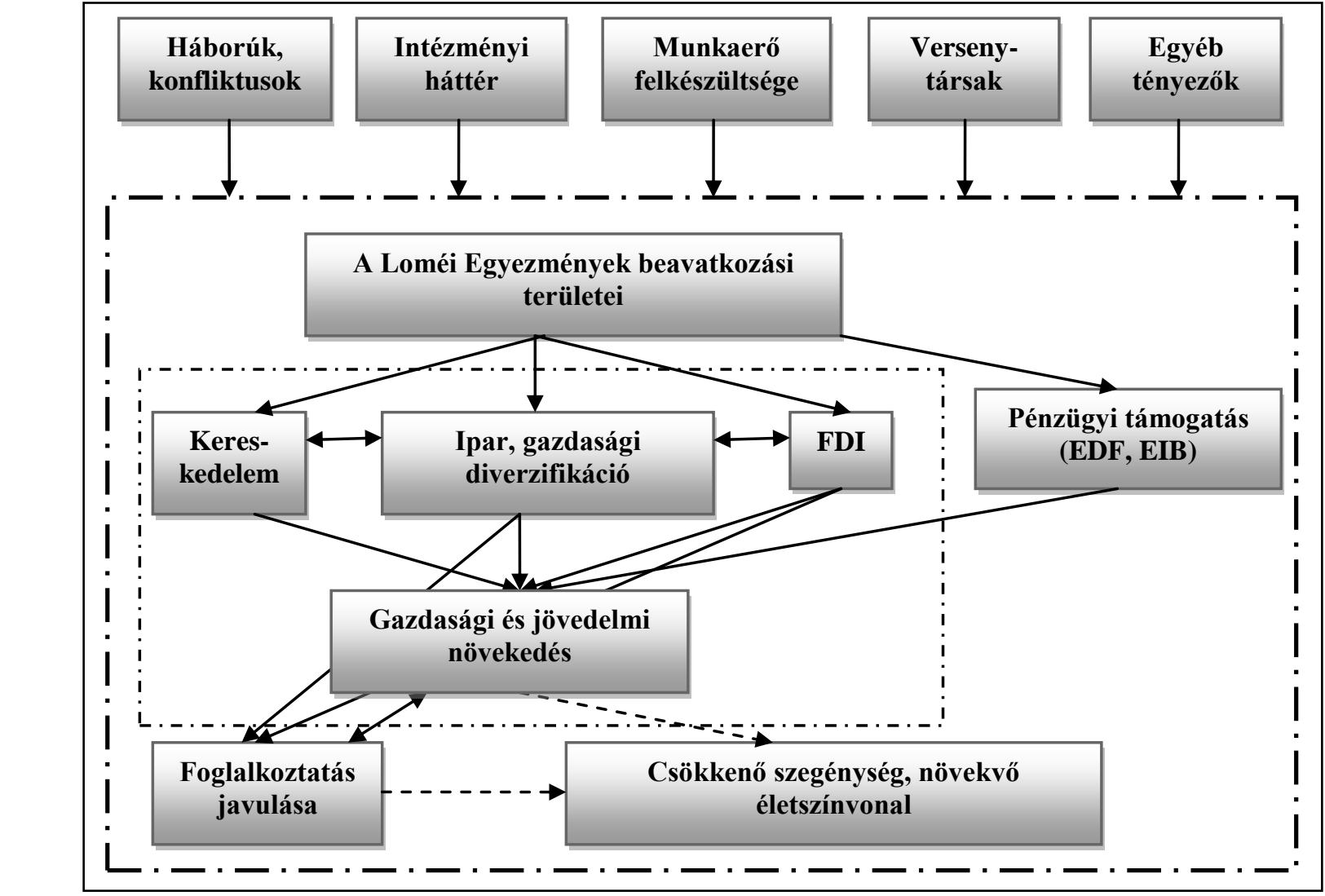

Forrás: saját szerkesztés

\footnotetext{
${ }^{78}$ E tényezők között a Lengyel-féle (versenyképességet meghatározó) piramis modell sikerességi faktorait fel lehetne sorolni, kiegészítve a fejlődő országok sajátosságaival.
} 
Az intézmények minőségét kétféle komplex indikátorral elemeztük. Mindkét időszak elemzése során figyelembe vettük a Szent-Iványi (2009a, 2009b) által is említett, a Freedom House által évente közzétett politikai jogok és polgári szabadság értékeit. Ezen komplex indikátor 1 és 7 közötti skálán mozgó értékeket vehet fel, ahol az 1 jelenti a teljes szabadságot, míg a 7 a teljes korlátozottságot (Freedom House 2011). Mivel ezzel csak a politikai szabadságról kaptunk információt, bevontuk még az ún. gazdasági szabadság indexét (index of economic freedom) is, mely többek között az üzleti, fiskális, kereskedelmi, monetáris, befektetési szabadságokat, illetve a korrupciót veszi számba. Az index értéke 0 és 100 közé eshet, ahol a 80 feletti érték a teljesen szabad, míg az 50 alatti az elnyomott gazdaságokat jelöli (Heritage Foundation és WSJ 2011). Ezen index esetében viszont az 1970-es évekre vonatkozóan nem volt elérhető adat, így kizárólag az egyezmények utáni időszak elemzéséhez használtuk fel.

\subsubsection{MóDSZERTANI ÁTTEKINTÉS: KLASZTERELEMZÉS}

Empirikus elemzésünk többváltozós statisztikai módszerek kombinációján alapul, amelyeket az SPSS 18.0 program segítségével végeztünk el. Végig a mutatók sztenderdizált értékeit használtuk, hiszen ezzel a különböző mértékegységek miatt fellépő torzítást kiküszöböltük, és lehetővé vált az összehasonlítás. Mivel a sztenderdizált változók szórása 1, így a változók azonos súllyal szerepelnek a vizsgálatban. Bár vannak olyan elemzések, ahol klaszterelemzésbe bevont indikátorokat valamilyen módszerrel súlyozzák (például Lukovics 2008), ezt szubjektív megoldásnak tartjuk, így az indikátorok súlyozását mellőztük.

Feltételezéseink szerint a Loméi Egyezmények hosszú távon jelentős kedvezményeket biztosítottak az aláíró ACP-országoknak, így (gazdasági) fejlődést kellene tapasztalnunk a Lomé-rendszer lejárta után a rendszer előtti időszakhoz képest. Ebből következően a két vizsgált időszak a Loméi Egyezményeket megelőző (1970-1975), illetve az azt követő időszak (2000-2005). ${ }^{79}$ A két időszak összehasonlítása klaszterelemzéssel történt, hiszen ennek a többváltozós statisztikai módszernek az a célja, hogy a vizsgálati egységeket adott indikátorok alapján homogén csoportba rendezze, amelynek eredményeként egy klaszter tagjai közelebb vannak egymáshoz (azaz jobban hasonlítanak egymásra), mint bármely más klaszter tagjához (Kovács et al 2006, Sajtos és Mitev 2007, Székelyi és Barna 2005). Annak érdekében, hogy a legmegbízhatóbb eredményeket kapjuk, a két időszak kétféle szempontú

\footnotetext{
${ }^{79}$ Mivel vizsgálatunkban kizárólag a Loméi Egyezmények végső hatásaira, eredményeire voltunk kíváncsiak, így nem elemeztük az egyes egyezmények előtti, illetve utáni időszakot.
} 
összehasonlítását végeztük el: egyrészt a Lomé-rendszer tagjainak számító ACP-országok eredményeit mindkét időszakban összevetettük a Loméi Egyezményeken kívüli országok teljesítményével; másrészt megfigyeltük a két időszak közötti különbségeket is.

Az elemzés során az egyezmények előtti időszak vizsgálata azt mutatja, hogy az ACPés a nem ACP-országok hogyan helyezkednek el egymáshoz képest anélkül, hogy bármelyikük is részesült volna valamilyen nagyobb, kiugró támogatásban. Ebből következően az egyezményeket megelőző időszak klaszterei mutatják a vizsgálatba bevont országok relatív helyzetét a beavatkozást megelőzően, hiszen a hasonló gazdasági eredménnyel rendelkező országok ugyanabba a csoportba kerültek. Következésképpen, ennek az időszaknak az elemzése során meg tudjuk határozni, hogy mely országok a fejlettebbek és melyek tekinthetők elmaradottnak a vizsgálatba bevont indikátorok alapján. Ezt a helyzetet összehasonlítva az egyezményeket követő időszakkal képet kaphatunk arra vonatkozóan, hogy a Loméi Egyezményeknek milyen eredményei voltak a vizsgált indikátorok alapján a bevont országok gazdaságára nézve. Ugyanis az egyezményeket követő időszak klaszterei már az egyezmények hatásait is tartalmazzák, és feltételeztük, hogy azok pozitív hatással bírtak az aláíró országok gazdasági eredményeire, így a klaszterek között változásnak kellett történnie. Így elemzésünk során két dolgot vetettünk össze a klaszterelemzéssel: egyrészt figyelmet szenteltünk a klaszterek változó jelentéseire, másrészt elemeztük a klasztertagság változását is.

A klaszterelemzés többféle módszer alapján történhet: egyaránt vannak hierarchikus és nem hierarchikus módszerek (Sajtos és Mitev 2007). Mivel nem rendelkeztünk ismerettel arra vonatkozóan, hogy hány klaszter lenne ideális, így többféle módszert alkalmaztunk, és a megfelelö klaszterszám meghatározása érdekében a bevált gyakorlatot követtük: ha nincs háttérinformáció a lehetséges klaszterek számára, az elemzést hierarchikus klaszterelemzéssel célszerü kezdeni, amit a nem hierarchikus követ (Sajtos és Mitev 2007). Ennek alapján vizsgálatunk során a hierarchikus klaszterelemzés (Ward-módszerrel) jelentette a kiindulópontot a lehetséges klaszterszámra vonatkozóan. Az így kapott lehetőségek elemzése a koefficiensek közötti különbség vizsgálatával történt, ugyanis a relatíve nagy differencia már azt mutatja, hogy a klaszterek egymástól távol vannak, és már nem érdemes ezeket összevonni (Sajtos és Mitev 2007).

A hierarchikus klaszterelemzés csak bizonytalan eredményeket mutatott, így ezeket ellenőrizni kellett: a lehetséges eseteket a K-közép klaszteranalízissel (mint nem hierarchikus módszerrel) vizsgáltuk. A kapott klasztereket mindkét időszakra vonatkozóan 
részletesen megvizsgáltuk: egyrészt elemeztük a klaszterközéppontokat, másrészt minden klaszter esetén megnéztük a bevont mutatók szórását. A klaszterközéppontok a klaszterek értelmezésében nyújtottak segítséget, míg a szórások vizsgálata a klaszterek homogenitásának elemzésére szolgáltak. Mivel a klaszterelemzés lényege az, hogy minél homogénebb csoportokat hozzunk létre, az egyes klaszterek szórásának a vizsgált mutatók esetében alacsonyabbnak kellene lennie, mint a teljes sokaságra nézve. Következésképpen, elemzésünk során mindkét időszak esetén azokat az eredményeket fogadtuk el, amelyek során egyrészt a klaszterek jelentése egyértelmüen meghatározható, másrészt a szórások alapján a leghomogénebb csoportokhoz jutottunk.

\subsubsection{A KLASZTERELEMZÉS GYENGESÉGEINEK KEZELÉSE}

Mielőtt a klaszterelemzés során kapott eredményeket részletezzük, fontos kiemelni néhány dolgot a módszerrel kapcsolatban. Egyrészt a klaszterelemzés eredményei teljes mértékben attól függnek, hogy milyen változókat vonunk be az elemzésbe, így az indikátorok módosítása, bővítése, szelektálása más eredményhez vezethet, azaz nem lehet legjobb megoldásról beszélni (Sajtos és Mitev 2007). Ebből kifolyólag jelen disszertációban a 4.3.1. fejezetben bemutatott indikátorok alapján végezzük el az elemzést. Ugyan törekedtünk arra, hogy minél objektívebben közelítsük meg a kérdést, hiszen számos - közvetlenül vagy közvetetten kapcsolódó - elemzést tekintettünk át a témában, és elméleti alapot adtunk a megközelítésnek (ahogyan azt Ketchen és Shook (1996) is javasolja), azonban az elemzői szubjektivitás mégis befolyásolhatta az indikátorok kiválasztását.

Továbbá, a klaszterelemzés során problémát jelenthet a változók közötti magas korreláció, a multikollinearitás jelenléte (Ketchen és Shook 1996), ami gazdasági-társadalmi vizsgálatok esetében gyakori jelenség (Lukovics és Lóránd 2010). A változók közötti korreláció torzított eredményre vezethet, ugyanis a magas korreláció és az annak következtében jelenlévő háttérfolyamatok elnyomhatják más változók szerepét. Ennek kezelése lehet a magasan korreláló változók közül az egyik kivonása a modellből, vagy a faktoranalízis (Ketchen és Shook 1996, Sajtos és Mitev 2007). Mivel esetünkben a kiválasztott indikátorok között magas korreláció van (különösen a gazdasági diverzifikációt leíró változók között), így a faktoranalízis alkalmazása mellett döntöttünk. Ennek oka, hogy véleményünk szerint a kiválasztott indikátorok leírják (vagy megközelítik) azokat a folyamatokat, amelyekre a Loméi Egyezmények hatással lehettek, így nem tartottuk megfelelőnek azt, hogy e változók közül néhányat kizárjunk a vizsgálatból. Összetett gazdasági folyamatokról van 
szó, amelyeket többféle indikátor megragadásával lehet kellő mértékben - és minél helyesebben - leírni. Ehhez hasonló megközelítés több tanulmányban is fellelhető (például Balatoni és Törös 2010, Biró 2009, Lukovics 2008, Lukovics és Lóránd 2010).

A faktoranalízis egy olyan eljárás, amely lehetővé teszi az adatok tömörítését, ezáltal a változók közötti multikollinearitás megszűntethetővé válik (Sajtos és Mitev 2007). Az elemzésünkben szereplő változókra a faktoranalízis helyett a fökomponens-analízist alkalmaztunk, mert célunk az indikátorok sürítése, nem pedig a háttérstruktúra kimutatása volt. Az általános eljárással szemben esetünkben több tényezőt is át kellett gondolni, emiatt pedig az elemzést némileg irányítani kellett. A főkomponens-analízis lefuttatása során az alábbiakat kellett figyelembe vennünk:

- az új fökomponensek (faktorok) az információ magas hányadát (legalább 75 százalékát) őrizzék meg;

- a fökomponensek meghatározása egyértelmü legyen, azaz ne csak matematikailag jussunk helyes megoldásra, hanem legyen gazdasági tartalma is;

- mivel két időszakot vizsgálunk és ezeket összevetjük, az összehasonlíthatóság miatt fontos, hogy a két időszakban ugyanazokat a főkomponenseket használjuk, és ne legyen eltérő számú és eltérő jelentéssel bíró főkomponens a két időszak között.

Első lépésként mindkét időszakra vonatkozóan a főkomponens-elemzést automatikusan futtattuk le. Ekkor azt vizsgáltuk, hogy a 14 változó ugyanúgy tömörül-e fökomponensekbe, vagy közöttük különbség található. Ugyan a fökomponensek az információ több mint 70 százalékát megőrizték mindkét időszakban, a számuk eltérő volt. Ez a két időszak összehasonlíthatóságát megkérdőjelezi, így úgy döntöttünk, hogy strukturált elemzést hajtunk végre. Ennek értelmében nem az összes változót vontuk be egyszerre, hanem kettébontottuk: először a gazdasági teljesítményt leíró, majd a külgazdasági teljesítményt közelítő indikátorokra futtattuk le a fökomponens-elemzést. A faktorok elnevezése a loading változók alapján történt, ami lényegében az adott faktor és az egyes indikátorok korrelációs együtthatója (Sajtos és Mitev 2007). Mivel a mezőgazdasági termelékenység egyedül határozta meg egy főkomponens tartalmát, így azt kivettük az elemzésből, csakúgy, mint a külkereskedelmi egyensúlyt elemző külkereskedelmi mérleget, valamint a „rosszul viselkedő” ipari hozzáadott értéket is. E három indikátort külön kezeljük, viszont mivel meghatározó szerepük van (hiszen a fökomponensekbe beilleszthetők lennének), így a főkomponensek mellett e három indikátort is szerepeltetjük a klaszterelemzésben. Hangsúlyozzuk tehát, hogy mindössze azért nem szerepelnek a 
fökomponensekben, mert a két időszakra ugyanazokat a fökomponenseket kellett kapnunk a két időszak összehasonlíthatósága érdekében.

Mivel a főkomponensekkel a célunk a multikollinearitás kiszürése volt, így e három kimaradt változó és a főkomponensek között sem lehet zavaró korreláció. Ennek ellenőrzése során szignifikáns, de gyenge korrelációt ( $r=0,2-0,3)$ tapasztaltunk, így nem tekintjük torzító tényezőnek e változók szerepeltetését a modellben. A két időszak - végleges, a későbbi statisztikai elemzéshez felhasznált - főkomponenseit (a loading változókkal együtt) a 4.3. táblázat tartalmazza. A kialakult főkomponensek esetében látható, hogy ugyanazon változók alakítják, és az új fökomponens és az eredeti indikátorok között a korreláció meglehetősen magas. Ezek az új faktorok több mint 75 százalékban (a külgazdasági teljesítmény esetén 80 százalék fölött) őrizték meg az eredeti változók információtartalmát.

4.3. táblázat A két időszak faktorai és loading változói

\begin{tabular}{|c|c|c|c|c|c|c|c|c|}
\hline \multirow[b]{2}{*}{ Indikátorok } & \multicolumn{4}{|c|}{$1970-1975$} & \multicolumn{4}{|c|}{$2000-2005$} \\
\hline & 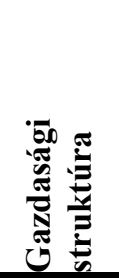 & 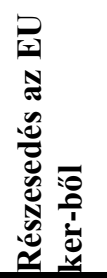 & 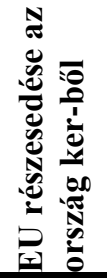 & 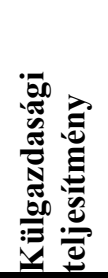 & 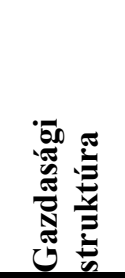 & 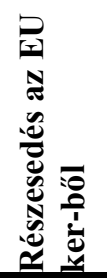 & 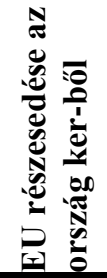 & 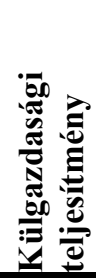 \\
\hline GDP/fö & $-0,867$ & & & & 0,900 & & & \\
\hline Szolgáltatások/GDP & $-0,849$ & & & & 0,834 & & & \\
\hline Mezógazdaság/GDP & 0,939 & & & & $-0,939$ & & & \\
\hline Mezógazdasági foglalkoztatottak & 0,821 & & & & $-0,786$ & & & \\
\hline $\begin{array}{l}\text { EU részesedése az ország } \\
\text { összexportjából }\end{array}$ & & & 0,926 & & & & 0,869 & \\
\hline $\begin{array}{l}\text { EU részesedése az ország } \\
\text { összimportjából }\end{array}$ & & & 0,906 & & & & 0,870 & \\
\hline $\begin{array}{l}\text { Részesedése az EU } \\
\text { összexportjából }\end{array}$ & & 0,974 & & & & 0,958 & & \\
\hline $\begin{array}{l}\text { Részesedése az EU } \\
\text { összexportjából }\end{array}$ & & 0,976 & & & & 0,957 & & \\
\hline Export/GDP & & & & 0,851 & & & & 0,703 \\
\hline Egy fóre jutó beáramló FDI & & & & 0,910 & & & & 0,716 \\
\hline Beáramló FDI a GDP arányában & & & & 0,875 & & & & 0,876 \\
\hline Információtartalom & $75,68 \%$ & & $85,44 \%$ & & $75,10 \%$ & & $82,11 \%$ & \\
\hline
\end{tabular}

Forrás: saját szerkesztés

A gazdasági struktúra faktora viszont további átalakítást igényelt. Ahogy a táblázatból is látszódik, a két időszakban más-más jelentéstartalma van: az első időszakban (1970-75) inkább a gazdasági infrastruktúra fejletlenségéről, a második időszakban (2000-05) a gazdasági struktúra fejlettségéről van szó a loading változók együtthatóinak előjele alapján. Azaz az első időszakban a faktorváltozó magasabb értéke fejletlenebb gazdasági struktúrát jelent, a második periódusban viszont a magasabb érték fejlettebb gazdasági struktúrára utal. 
Alapjában véve ez nem tekinthető problémának, mindössze a klaszterek jellemzése során kell erre figyelni. Viszont a kérdés megoldható azzal, ha a faktorok értékeit valamelyik időszakban (-1)-gyel megszorozzuk, így tartalmában ugyanaz lesz a két időszak e faktorának jelentése. Ez utóbbi megoldás mellett döntöttünk, és az első időszak értékeinek ellentettjét vettük az az értelmezési problémák elkerülése érdekében. Azaz elemzésünkben a gazdasági struktúra faktor magasabb értéke - mindkét időszakban - a fejlettebb gazdasági szerkezetre utal.

Mindezek alapján a változók közötti multikollinearitást megszüntettük, azaz a változók közötti korreláció nem nyomhatja el más változók hatásait. Ez lehetővé teszi azt, hogy a vizsgálatba bevont országokat eredményesebben értékeljük a Loméi Egyezményekhez köthető gazdasági teljesítményük alapján. Mivel nincs egyértelmüen jó megoldás a probléma kezelésére, Ketchen és Shook (1996) javaslata szerint többféle variációt szükséges elemezni. Ennek alapján járunk el saját elemzésünk során, és a következőkben egyaránt bemutatjuk az eredeti 14 változó alapján lefutatott klaszterelemzést és a fökomponensekkel kapott eredményeket, rámutatva a kétféle megközelítés különbségeire.

\subsubsection{A LOMÉI EGYEZMÉNYEKET MEGELŐZŐ IDŐSZAK EREDMÉNYEI}

A Loméi Egyezményeket megelőző időszakra (1970-75) vonatkozóan a hierarchikus klaszterelemzés szerint hat klaszter tünt ideálisnak a koefficiensek közötti távolság elemzése alapján. Ezt a megoldást a K-közép elemzéssel igyekeztünk pontosítani, és hat klaszterre vonatkozóan futtattuk le az elemzést. Ennek eredményeként négy kis tagszámú klasztert kaptunk (4.4. táblázat), melynek oka lehet a kiugró országok torzító hatása. A klaszterek számának csökkentésével is megpróbálkoztunk, abban bízva, hogy az egytagú klaszter megszünik és beolvad valamelyik másikba, ehelyett viszont egy 70 országból álló csoportot kaptunk és a kiugró országok megmaradtak. Mivel a klaszterelemzés a kiugró értékekre nagyon érzékeny (Sajtos és Mitev 2007), így a vizsgálat során az outlier értékeket kezelnünk kellett. Összességében a vizsgálatunk során három országot (Bahamák, Barbados és Belize) találtunk kiugrónak, így ezeket a későbbi vizsgálatunkból kizártuk, azaz a további vizsgálatunkat 79 országra vonatkozóan végeztük el. 
4.4. táblázat Klaszterek tagsága 6 klaszter esetén (országok száma, db)

\begin{tabular}{ccc}
\cline { 2 - 2 } Klaszter & Tagok száma \\
\cline { 2 - 3 } & $\mathbf{1}$ & 4 \\
\hline-2 & $\mathbf{2}$ & 4 \\
\hline $\mathbf{3}$ & 1 \\
\hline $\mathbf{4}$ & 28 \\
\hline Összesen & $\mathbf{5}$ \\
\hline
\end{tabular}

Forrás: saját számítás

A 79 országra vonatkozóan újra lefutatott hierarchikus módszer alapján szintén 4-6 klaszter tünt ideálisnak. Ennek megfelelően a K-közép elemzéssel ezeket a lehetőségeket vizsgáltuk (4.5. táblázat). Ahogyan növeltük a klaszterek számát, úgy lettek egyre kisebb elemszámú klasztereink, miközben lett egy nagy elemszámú klaszter. Azonban nem tekinthetjük helyes megoldásnak, ha a vizsgált 79 ország közül 65, illetve 66 egy csoportba kerül, miközben mellette 1-5 elemü klaszterek is vannak. Ennek következtében a 4 klaszteres megoldást tekintjük ideálisnak, melyet igazol az is, hogy az ezekben a csoportokban lévő szórás a vizsgálatba bevont indikátorok esetében alacsonyabb, mint a teljes minta szórása, azaz homogén csoportokat sikerült létrehozni.

4.5. táblázat A klasztertagság alakulása különböző számú klaszterek esetében (országok száma, db)

\begin{tabular}{ccccc}
\hline Klaszter & 4 klaszter & 5 klaszter & 6 klaszter \\
\hline $\mathbf{1}$ & 4 & 3 & 3 \\
\hline $\mathbf{2}$ & 4 & 1 & 4 \\
\hline $\mathbf{3}$ & 28 & 66 & 1 \\
\hline $\mathbf{4}$ & 43 & 5 & 5 \\
\hline $\mathbf{5}$ & - & - & 4 & 65 \\
\hline Összesen & $\mathbf{7 9}$ & $\mathbf{7 9}$ & $\mathbf{7 9}$ \\
\hline
\end{tabular}

Forrás: saját számítás

A négy klaszter elnevezése a klaszterközéppontok, valamint az egyes csoportok mintához viszonyított átlagai és szórása alapján történt. Ennek alapján a 79 ország 4 klasztere az alábbiak szerint nevezhető el. A vizsgálatba bevont relatíve sok ország miatt arra nincs lehetőség, hogy minden klaszter esetén felsoroljuk annak tagjait (ez a 2. számú mellékletben megtalálható), viszont szemléltetésként néhány országot megemlítünk.

- Relatíve fejlett, zárt gazdaságok (1. klaszter), ahol ugyan kiemelkedően magas az EU kereskedelméből való részesedés, viszont alacsony nyitottság jellemzi ezeket az 
országokat mind a kereskedelem, mind pedig a külföldi tőke szempontjából. Kiemelkedően magas az egy főre jutó GDP, és a gazdasági szektorok közül az ipar a meghatározó. A négy ország Argentína, Brazília, Izrael, valamint Nigéria.

- Relative fejlett, nyitott gazdaságok (2. klaszter), ahol bár magas a gazdaságok nyitottsága mind kereskedelmi, mind a külföldi tőke szempontjából, az EU mégsem fontos kereskedelmi partner számukra és viszont. A gazdasági ágazatok közül a szolgáltatások a domináns, a mezőgazdaság aránya rendkívül alacsony. A klaszter négy országa Panama, Seychelle-szigetek, Szingapúr, illetve Trinidad és Tobago.

- Fejletlen, zárt agrárgazdaságok (3. klaszter), melyekben a GDP/fó a legalacsonyabb, kiemelkedően magas a mezőgazdaság és a mezőgazdaságban foglalkoztatottak aránya, miközben a szolgáltatások és az ipar nem játszik meghatározó szerepet. Az EU fontos kereskedelmi partner a számukra, viszont ez fordítva már nem igaz. Átlagon aluli nyitottsággal rendelkeznek a kereskedelem terén, és a külföldi tőke számára sem vonzóak. A klaszter 28 országa közé került például Bangladesh, Ghána, Etiópia, Mali, Madagaszkár.

- Átlagosan fejlett gazdaságok (4. klaszter), melyek a teljes mintához közeli átlagos egy főre jutó GDP-vel rendelkeznek, az EU nem kiemelkedően fontos számukra, a teljes mintához hasonló átlagos gazdasági szerkezettel rendelkeznek. A klaszter 43 országa közé tartozik például Chile, Costa Rica, Egyiptom, Uruguay és Zambia.

A vizsgálatba bevont indikátorok alapján így egy fejlettségbeli rangsor is megállapítható a klaszterek között. A hierarchia legalján a fejletlen, zárt agrárgazdaságok (3. klaszter) találhatók, őket követi az átlagosan fejlett gazdaságok (4. klaszter), majd a relative fejlett, zárt gazdaságok (2. klaszter) és a relatíve fejlett, nyitott gazdaságok (1. klaszter) állnak a hierarchia tetején. Az intézmények minőségét tekintve (4.6. táblázat) a fejletlent zárt agrárgazdaságok között a sokkal korlátozottabb lehetőségekkel rendelkező országokat találjuk. A négy klaszter értékeit tekintve az is elmondható, hogy az intézményi háttér egyre kedvezőbb: minél magasabb szintü klaszterben van egy ország, annál pozitívabb az intézmények minőségét jelző indikátor értéke. 
4.6. táblázat Az intézmények minősége az egyes klaszterekben

\begin{tabular}{lcc}
\hline 1. időszak klaszterei & Átlag & $\begin{array}{c}\text { Országok } \\
\text { száma }\end{array}$ \\
\hline Fejletlen, zárt agráro. & 5,6384 & 28 \\
\hline Átlagosan fejlett 0 - & 4,1756 & 42 \\
\hline Relatíve fejlett, zárt o. & 3,8438 & 4 \\
\hline Relatíve fejlett, nyitott o. & 3,7813 & 4 \\
\hline Teljes minta & $\mathbf{4 , 6 6 3 5}$ & $\mathbf{7 8}$ \\
\hline
\end{tabular}

Megjegyzés: Az 1-hez közeli értékek a kedvezöbb (szabadabb), míg a 7-hez közeli értékek a kedvezötlenek (korlátozott). Az átlagosan fejlett országok esetében Vanuatura vonatkozóan nem volt elérhető adat.

Forrás: saját számítás

A Loméi Egyezményeket követő időszak elemzése szempontjából fontos információt hordoz magában, hogy az egyes klaszterekben lévő országok földrajzi megoszlásáról lehet-e általánosságokat megfogalmazni. A 4.7. táblázat tartalmazza ezeket az eredményeket.

4.7. táblázat A régiók és a klaszterek kereszttáblája (országok száma, db)

\begin{tabular}{|c|c|c|c|c|c|}
\hline & $\begin{array}{l}\text { Fejletlen, zárt } \\
\text { agrárgazda- } \\
\text { ságok (3.) }\end{array}$ & $\begin{array}{c}\text { Átlagosan } \\
\text { fejlett } \\
\text { gazdaságok (4.) }\end{array}$ & $\begin{array}{l}\text { Relatíve fejlett, } \\
\text { zárt } \\
\text { gazdaságok (2.) }\end{array}$ & $\begin{array}{c}\text { Relatíve fejlett, } \\
\text { nyitott } \\
\text { gazdaságok (1.) }\end{array}$ & Összesen \\
\hline Afrika (ACP) & 24 & 13 & 1 & 1 & 39 \\
\hline $\begin{array}{l}\text { Karibi-térség } \\
(\mathrm{ACP})\end{array}$ & 1 & 4 & 0 & 1 & 6 \\
\hline $\begin{array}{l}\text { Csendes-óceáni } \\
(\mathrm{ACP})\end{array}$ & 0 & 3 & 0 & 0 & 3 \\
\hline Latin-Amerika & 0 & 12 & 2 & 1 & 15 \\
\hline Azsia & 3 & 5 & 0 & 1 & 9 \\
\hline $\begin{array}{l}\text { Eszak-Afrika és } \\
\text { Közel Kelet }\end{array}$ & 0 & 5 & 1 & 0 & 6 \\
\hline $\begin{array}{l}\text { Csendes-óceáni } \\
(\text { nem-ACP) }\end{array}$ & 0 & 1 & 0 & 0 & 1 \\
\hline Összesen & 28 & 43 & 4 & 4 & 79 \\
\hline
\end{tabular}

A kereszttábla egyértelműen mutatja, hogy a legfejletlenebb 3. klaszterben (zárt agrárgazdaságok) az országok több mint 85 százaléka Afrikában található, illetve az afrikai országok 61,5 százaléka ebben a csoportban helyezkedik el, azaz a leendő ACPországok nagy része a legkevésbé fejlett országok közé tartozik a vizsgált mintán belül. Bár az átlagosan fejlett országok klasztere is relatíve sok országot tartalmaz, ebben a régiók szerinti megoszlás sokkal heterogénebb: minden régióból találhatók itt országok, és egyik régió sem tekinthető kiemelkedőnek arányaiban nézve.

Elemzésünk azt mutatja, hogy a Loméi Egyezményeket megelőző időszakban a vizsgálatba bevont fejlődő országok fejlettségi szintjüket tekintve (a vizsgált indikátorok 
alapján) relatíve közel helyezkednek el egymáshoz képest, hiszen nyolc ország kivételével két klasztert tudtunk meghatározni: létezik egy relatíve fejlettebb országokból álló csoport, valamint egy relatíve fejletlen gazdaságokból álló csoport. Azonban ezek viszonylag közel helyezkednek el egymáshoz képest. Emellett a később ACP-országokká vált afrikai államok többsége a legkevésbé fejlettnek tekinthető klaszterbe került, így a Loméi Egyezmények beavatkozása szükségesnek tűnik, és volt lehetőség látványos eredmény elérésére. Viszont felmerül a kérdés - különösen a klaszterelemzés gyengeségeinek ismeretében -, hogy ezeket az eredményeket mennyiben befolyásolhatta a változók közötti multikollinearitás jelenléte: valóban elnyomhatta néhány tényező hatását a más tényezők közötti kapcsolat mögött meglévő háttérfolyamat? Ennek tesztelése érdekében a 4.3.3. fejezetben ismertetett főkomponensek segítségével újra elvégeztük a klaszterelemzést a fent ismertetett folyamat teljes megismétlésével.

\subsubsection{A LOMÉ-RENDSZER ELŐTTI IDŐSZAK ELEMZÉSE: FŐKOMPONENSEK BEVONÁSA}

A klaszterelemzés 4.3.3. fejezetben említett gyengesége miatt újra lefuttattuk az elemzést a kialakított faktorokkal is. Így a változók közötti multikollinearitás kezelésével kiszürhetőek azok a háttérfolyamatok, amelyek esetleg elnyomhatták egy-egy tényező hatását. A főkomponens-analízis eredményeinek megfelelően négy faktorral (gazdasági struktúra, az EU-függőség, szerep az EU-ban, illetve külgazdasági teljesítmény) végeztük el az elemzést, melyek mellett szerepeltettük még a külgazdasági egyensúlyt mutató külkereskedelmi mérleget, a gazdasági struktúrához közel álló ipari hozzáadott értéket, valamint a mezőgazdasági termelékenységet is.

A faktorok segítségével elvégezve az elemzést az alábbi eredményre jutottunk a Loméi Egyezményeket megelőző időszakot illetően. A hierarchikus elemzés alapján a 4 és 5 klaszteres megoldás között kellett választanunk. A 4 klaszteres megoldást elvetettük, hiszen rendre 1, 4, 29 és 45 ország került egy-egy csoportba, melynek következtében a legkisebb és a legnagyobb elemü csoport között óriási a különbség. Az 5 klaszteres megoldás már relatíve kiegyenlítettebb eredményre vezetett (4.8. táblázat), bár itt is relatíve nagy a különbség a legszükebb és a legbővebb elemü klaszter között. A további bontás viszont már a klaszterek értelmezését nehezítette meg, így végül az ötklaszteres megoldás mellett maradtunk. 
4.8. táblázat Az 5 klaszter a faktorokkal az első időszakban (országok száma, db)

Forrás: saját szerkesztés

\begin{tabular}{cc}
\hline Klaszter & Tagok száma \\
\hline $\mathbf{1}$ & 24 \\
\hline $\mathbf{2}$ & 5 \\
\hline $\mathbf{3}$ & 38 \\
\hline $\mathbf{4}$ & 8 \\
\hline $\mathbf{5}$ & 4 \\
\hline Összesen & $\mathbf{7 9}$ \\
\hline
\end{tabular}

A klaszterek elnevezése a faktorok és a bevont indikátorok átlagai és szórásai alapján a következőképpen alakul, egyben fejlettségi sorrendet is felállítva (a legmagasabb fejlettségi szinttől kezdve), a tagságot a 2. számú melléklet tartalmazza.

- Önálló, fejlett és nyitott országok, melyek esetében kiemelkedő a külgazdasági teljesítmény, de nem jelentősek az EU-kapcsolatok. Mindemellett a mintában ezen országok gazdasági struktúrája a legfejlettebb (2. klaszter). E csoportba tartozik többek között Jamaica, Panama és a Seychelle-szigetek.

- Relative fejlett, EU-érdekeltségü országok, melyek átlagot meghaladó fejlettségü gazdasági struktúrával rendelkeznek, és az EU számára kiemelt jelentőséggel bíró kereskedelmi országokról van szó (5. klaszter). Argentína, Brazília, Izrael és Nigéria a négy ország a klaszterben.

- Relative fejlett és zárt országok, melyek gazdasági struktúrájának színvonala kiemelkedő (az 5. klaszteréhez hasonló), viszont külgazdasági teljesítményük fejlettségi szintjükhöz képest jóval elmarad az átlagtól (4. klaszter). Többek között Vanuatu, Szíria és a Comore-szigetek található ebben a csoportban.

- EU-függő, elmaradott országok, melyek elmaradott gazdasági struktúrával rendelkeznek, viszont az EU kiemelkedően fontos kereskedelmi kapcsolataikban (1. klaszter). A 24 ország közé tartozik Angola, Benin, Kongó, Gabon, Niger és Ghána is.

- Elmaradott és zárkózott országok, melyek a mintában a legfejletlenebb gazdasági struktúrával rendelkeznek, és rendkívül alacsony szintü a külgazdasági teljesítményük is (3. klaszter). A tagok között megtalálható például Csád, Bolívia, Kenya, Mali és Thaiföld is.

Ami a klaszterek földrajzi megoszlását illeti, az alábbiak mondhatók el (4.9. táblázat). A leendő afrikai ACP-országok 87 százaléka (összesen 34 ország) a két legkevésbé fejlett klaszter között oszlik meg, de valamivel többen találhatók az EU-tól függő országok, azaz 
azok az államok, melyek számára - már az ekkor kialakult EU-függőségük miatt - a Loméi Egyezmények kitörési lehetőséget jelenthettek. Emellett kiemelendő, hogy a mintába került latin-amerikai fejlődő országok nagy része (80 százalékuk) ebben az időszakban még az elmaradott és zárt országok közé tartozott a vizsgált indikátorok alapján. Ez nem meglepő, hiszen ebben az időszakban élte virágkorát az importhelyettesítés ebben a térségben.

\begin{tabular}{|c|c|c|c|c|c|c|}
\hline & $\begin{array}{l}\text { Elmara- } \\
\text { dott és } \\
\text { zárkózott } \\
\text { országok }\end{array}$ & $\begin{array}{c}\text { EU-függő, } \\
\text { elmaradott } \\
\text { országok }\end{array}$ & $\begin{array}{c}\text { Relatíve } \\
\text { fejlett és } \\
\text { zárt } \\
\text { országok }\end{array}$ & $\begin{array}{c}\text { Relatíve } \\
\text { fejlett, EU- } \\
\text { érdekeltségü } \\
\text { országok }\end{array}$ & $\begin{array}{l}\text { Önálló, fejlett és } \\
\text { nyitott országok }\end{array}$ & Összesen \\
\hline Afrika (ACP) & 13 & 21 & 3 & 1 & 1 & 39 \\
\hline Karibi (ACP) & 3 & 0 & 1 & 0 & 2 & 6 \\
\hline $\begin{array}{l}\text { Csendes-óceáni } \\
\text { (ACP) }\end{array}$ & 2 & 0 & 1 & 0 & 0 & 3 \\
\hline Latin-Amerika & 12 & 0 & 0 & 2 & 1 & 15 \\
\hline Azsia & 7 & 0 & 1 & 0 & 1 & 9 \\
\hline $\begin{array}{l}\text { Észak-Afrika és } \\
\text { Közel-Kelet }\end{array}$ & 1 & 2 & 2 & 1 & 0 & 6 \\
\hline $\begin{array}{l}\text { Csendes-óceáni } \\
\text { (nem-ACP) }\end{array}$ & 0 & 1 & 0 & 0 & 0 & 1 \\
\hline Összesen & 38 & 24 & 8 & 4 & 5 & 79 \\
\hline
\end{tabular}

Megjegyzés: A Chi-négyzet próbájának p-értéke 0,003, azaz szignifikáns kapcsolat van a két változó között. Forrás: saját szerkesztés

Az intézményi háttér vizsgálata sem maradhat ki, hiszen utaltunk arra, hogy az intézményi háttér (is) befolyással bír a Loméi Egyezmények adta lehetőségek magas szintü kihasználására. Az intézményi minőség jellemzőit a 4.10. táblázat tartalmazza. Ez esetben is egyértelmüen igaz, hogy minél magasabb fejlettségü klaszterbe tartozik az ország, az intézmény minőségét jelző indikátor annál kedvezőbb értéket vesz fel. Ebből kifolyólag a két elmaradott - ráadásul viszonylag nagy elemszámú - klaszterek esetében különösen fontos az, hogy az intézményi háttér is fejlödjön, máskülönben az egyezmények adta lehetőségeket nem tudják kihasználni.

A kétféle módszer alapján elvégzett klaszterelemzés tekintetében jelentős módosulás történt a klasztertagságban: a korábbi 43 és 28 tagsággal rendelkező klaszterek keveredéséből alakultak ki jelen esetben az új csoportok. Ugyan az elnevezésekben a kétféle módszer (eredeti változókkal és faktorokkal lefuttatott klaszterelemzés) között hasonlóság mutatkozik, az utóbbi esetben viszont jobban elkülöníthetőek az országok a külgazdasági teljesítményük alapján. Így a főkomponensekkel végzett vizsgálat eredményeit tekintjük elsődlegesnek. Ebből kifolyólag a második időszakban már csak e módszer alapján részletezzük az eredményeket. 
4.10. táblázat Az intézményi minőség a klaszterekben

\begin{tabular}{lccc}
\hline Klaszter & Átlag & Szórás & N \\
\hline Elmaradott és zárkózott országok & 4,6941 & 1,55710 & $\mathbf{3 8}$ \\
\hline EU-függó, elmaradott országok & 5,1927 & 1,59652 & $\mathbf{2 4}$ \\
\hline Relatíve fejlett és zárt országok & 4,1071 & 1,82493 & $\mathbf{7}$ \\
\hline Relatíve fejlett, EU-érdekeltségú országok & 3,8438 & 1,23480 & $\mathbf{4}$ \\
\hline Önálló, fejlett és nyitott országok & 3,3250 & 2,29061 & $\mathbf{5}$ \\
\hline Összesen & $\mathbf{4 , 6 6 3 5}$ & $\mathbf{1 , 6 6 8 8 4}$ & $\mathbf{7 8}$ \\
\hline
\end{tabular}

Megjegyzés: az 1-hez közeli értékek a kedvezőbb (szabadabb), míg a 7-hez közeli a kedvezőtlen (korlátozott). Vanuatu esetében nem volt elérhető adat.

Forrás: saját számítás

\subsubsection{A LOMÉ-RENDSZERT KÖVETŐ IDŐSZAK EREDMÉNYEI}

Mielőtt a faktorokkal történő elemzésre térnénk rá, fontos kiemelni azt, hogy az eredeti változókkal történő elemzés legelején milyen problémákkal szembesültünk, ami indokolta azt, hogy inkább a faktorokkal történő elemzést tekintsük elsődlegesnek. Az eredeti változókon alapuló elemzés szerint a Loméi Egyezményeket követő időszakban (2000-05) a hierarchikus elemzés koefficienseinek áttekintése után 4 és 6 között van az ideálisnak tünő klaszterek száma. A Loméi Egyezményeket megelőző időszakra vonatkozóan elvégzett vizsgálathoz hasonlóan a K-közép elemzéssel a Loméi Egyezményeket követő időszak esetében is végignéztük a lehetséges variánsokat (4.11. táblázat).

4.11. táblázat A lehetséges klaszterek tagjainak alakulása (országok száma, db)

\begin{tabular}{ccccc}
\hline Klaszter & & 4 klaszter & 5 klaszter & 6 klaszter \\
\cline { 2 - 5 } 1 & 1 & 6 & 6 \\
2 & 61 & 1 & 1 \\
3 & 11 & 4 & 1 \\
4 & 6 & 30 & 27 \\
5 & - & 38 & 35 \\
6 & - & - & 9 \\
\hline Összesen & $\mathbf{7 9}$ & $\mathbf{7 9}$ & $\mathbf{7 9}$ \\
\hline
\end{tabular}

Forrás: saját számítás

Ebben az esetben a 4 klaszteres megoldást a rendkívül egyenlőtlen elosztás miatt kizártuk, hiszen a 79 országunkból 61 került egy csoportba. Emellett egy fontos elem is kitünik ezen variációk elemzése alapján: egy ország (nevezetesen Szingapúr) minden esetben külön klasztert alkot. Mivel a klaszterelemzés érzékeny a kiugró értékekre, így Szingapúrt kivettük a további elemzésből, egy különálló országnak tekintjük, és a klaszterelemzést lefuttattuk a bent maradt 78 országra is (még mindig az eredeti 14 változóval). A 78 országos változat - azaz a kiugró ország kizárása - nem sok újdonságot hozott az elemzésbe (4.12. táblázat). Mind a 4, mind az 5 klaszteres megoldás esetében két-két relatíve nagyszámú klaszter adódott, míg a másik kettő, illetve három klaszter kis elemszámú. A további bontás 
(azaz a hat klaszter kialakítása) sem hozott új eredményt. Mindemellett összevetve a 79 országos 5 klaszter tagságát a 78 országos 5 klaszter tagságával, érdemi különbséget nem lehet megállapítani: mindösszesen kettő ország került át másik klaszterbe!

4.12. táblázat A klaszterek tagsága Szingapúr kizárásával (országok száma, db)

\begin{tabular}{ccccc}
\hline Klaszter & 4 klaszter & 5 klaszter & 6 klaszter \\
\hline 1 & 5 & 5 & 5 \\
2 & 8 & 2 & 38 \\
3 & 32 & 4 & 1 \\
4 & 33 & 29 & 28 \\
5 & - & 38 & 2 \\
6 & - & - & 4 \\
\hline & - & 78 & $\mathbf{7 8}$ \\
\hline
\end{tabular}

Forrás: saját számítás

Az, hogy az országok több mint 80 százaléka két klaszterbe sorolható, és hogy a legnagyobb és a legkisebb elemszámú klaszter között közel húszszoros a különbség, indokolja, hogy más megközelítést alkalmazzunk a klaszterek lehatárolására. Nem feltétlenül ez az oka, de a változók közötti multikollinearitás elnyomhatja olyan tényezők hatását, amelyek hatással lehetnek az osztályozás kialakítására. Ebböl kifolyólag a következőkben kizárólag az ennek kezelésére alkalmazott fökomponens-analízissel kiegészített klaszterelemzés eredményeit ismertetjük.

A főkomponensekkel történő osztályozás során is további finomításra volt szükség, ugyanis - ahogyan azt az eredeti indikátorok alapján történt elemzés is kimutatta - Szingapúr kiugró értéknek minősül, így a továbbiakban Szingapúrt egy külön klaszterként (Csúcsország) kezeljük, és ezen kívül határozzuk meg a mintából kialakítható, egymástól különböző csoportokat. A Szingapúr nélküli 78 fejlődő ország vonatkozásában szintén öt klaszter tűnt ideális megoldásnak, hiszen a négyklaszteres megoldás esetén súlypont eltolódás volt (rendre 4, 14, 10, 50 elemü csoportok), a hatklaszteres megoldás pedig nem értelmezhető. Az ötklaszteres megoldás esetében sokkal kiegyensúlyozottabb eredmény látható (4.13. táblázat).

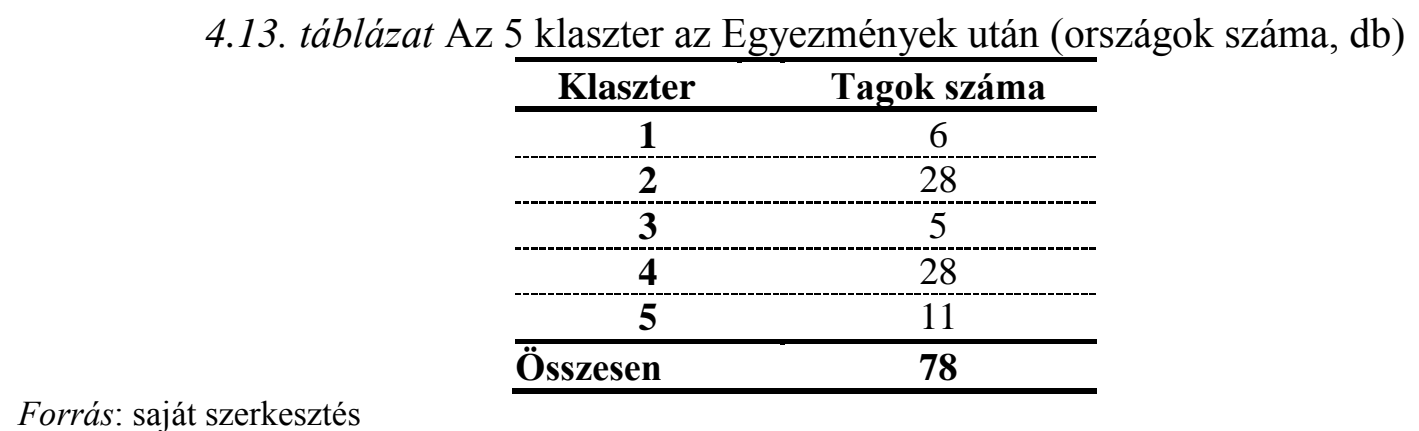


A klaszterek elnevezése a bevont változók átlagai és szórása alapján történt. Ennek alapján az alábbi csoportokról beszélhetünk, már egy fejlettségi sorrendet is felállítva (a legmagasabb fejlettségi szinttől kezdve), a tagságot a 3. számú melléklet tartalmazza:

- Fejlett és nyitott országok EU-érdekeltséggel, melyek esetében a gazdasági struktúra fejlettségi szintje a legmagasabb, és az EU számára fontos kereskedelmi partnerek, de ez fordítva már nem igaz (3. klaszter). Többek között itt található Argentína, Brazília, illetve Thaiföld is.

- Relatíve fejlett, nyitott, EU-érdekeltségü országok, ahol a gazdasági struktúra fejlettségi szintje jóval átlag felett van, és az EU fontos kereskedelmi partner számukra (5. klaszter). A tagok közül megemlíthető a Seychelle-szigetek, Tunézia és Marokkó.

- Az EU-tól független, relative fejlett, átlagos nyitottságú országok, ahol a gazdasági struktúra fejlettségi szintje átlag feletti, akárcsak a külgazdasági teljesítményük. Viszont a csoport fontos ismérve az, hogy az EU - a többi klaszterhez és a minta átlagához képest - sokkal kisebb szerepet játszik a kereskedelmi kapcsolataikban (4. klaszter). Ebben a csoportban található például Uruguay, Sri Lanka, Panama és Egyiptom is.

- Az EU-tól függő, elmaradott országok, melyek gazdasági struktúrája elmaradottságot jelez, többnyire a mezőgazdaság dominál, viszont az EU fontos kereskedelmi partner számukra (1. klaszter). Például Angola, Csád és Kongó került ebbe a klaszterbe.

- Az EU-tól függö, elmaradott országok elmaradott külgazdasági teljesitménnyel, ahol elmaradott a gazdasági szerkezet, alacsony a mezőgazdaság termelékenysége, viszont az EU fontos szerepet játszik kereskedelmi kapcsolataikban (2. klaszter). A 28 klasztertag között megtalálható Benin, Etiópia, Laosz, Kenya és Niger is.

Ezek alapján látható, hogy az előző időszakhoz nagymértékben hasonlító klasztereket kaptunk, ez pedig megkönnyíti a két időszak eredményeinek összehasonlítását. Emellett érdemes megvizsgálni az intézményi hátteret jellemző indikátorok alakulását ezekben a klaszterekben is (4.14. táblázat). Szingapúrt - mint külön kezelendő csoportot - is feltüntettük a táblázatban. Ezek az indikátorok is egyértelmüen arra utalnak, hogy a jobb gazdasági struktúrával és a kedvezőbb külgazdasági teljesítménnyel a szabadabb országok rendelkeznek (bár Szingapúr eltérően viselkedik a politikai szabadság tekintetében, viszont a gazdasági szabadság indexe messze a legmagasabb a mintában). Továbbá erös törés látszódik mindkét 
mutató esetében a fejlett (a táblázat első két sora Szingapúr után) és az elmaradott országok (a táblázat utolsó három sora) között.

4.14. táblázat Az intézményi háttér minősége az egyezmények után

\begin{tabular}{llccc}
\hline & \multicolumn{2}{c}{ Politikai szabadság } & \multicolumn{2}{c}{ Gazdasági szabadság } \\
\hline Klaszter & Átlag & N & Atlag & N \\
\hline Csúcsország (Szingapúr) & 4,6667 & 1 & 88,1 & 1 \\
\hline $\begin{array}{l}\text { Fejlett és nyitott országok EU- } \\
\text { érdekeltséggel }\end{array}$ & 2,7833 & 5 & 62,96 & 5 \\
\hline $\begin{array}{l}\text { Relatíve fejlett, nyitott, EU-érdekeltségú } \\
\text { országok }\end{array}$ & 3,1667 & 11 & 57,23 & 5 \\
\hline $\begin{array}{l}\text { Az EU-tól független, relatíve fejlett, átlagos } \\
\text { nyitottságú országok }\end{array}$ & 3,0327 & 28 & 61,48 & 27 \\
\hline Az EU-tól függó-_elmaradott országok & 4,8056 & 6 & 48,67 & 6 \\
\hline $\begin{array}{l}\text { Az EU-tól függö, elmaradott országok } \\
\text { elmaradott külgazdasági teljesítménnyel }\end{array}$ & 4,5565 & 28 & 51,16 & 25 \\
\hline Összesen & $\mathbf{3 , 7 1 9 0}$ & $\mathbf{7 9}$ & $\mathbf{5 6 , 4 7}$ & $\mathbf{6 7}$ \\
\hline
\end{tabular}

Megjegyzés: A politikai szabadság esetén az 1-hez közeli értékek a kedvezőbb (szabadabb), míg a 7-hez közelítő értékek a kedvezőtlenek (korlátozott). A gazdasági szabadság esetében a 80 feletti érték a szabadságot, míg az 50 alatti az elnyomást, a 60 és 70 közötti érték a mérsékelt szabadságot jelöli. 11 országra nem volt elérhető adat.

Forrás: saját számítás

Mindezek mellett a kedvezményezetti csoportok alakulását, valamint a Loméi Egyezmények aláírását is meg kell vizsgálnunk (4.15. táblázat). Az ACP-országok fele egy klaszterbe került (a legfejletlenebbnek minősített csoportba), míg a másik fele szétszórtan helyezkedik el. Ebből kifolyólag az ACP-országok között egyértelműen megtalálhatók a jobb és a kevésbé jobb eredményekkel rendelkező országok - holott az egyezmények előtti időszakban nem lehetett ilyen jól elkülöníti egymástól ezeket az országokat. Az egyéb kedvezményezetti csoportba tartozó országok jellemzően a kedvezőbb indikátorokkal jellemezhető csoportokba kerültek. De a legkedvezőtlenebb csoportba került országok zömében az ACP-országok közé sorolhatók (a 28 klasztertagból 24 ebbe a csoportba tartozik).

Ezt az eredményt érdemes a szerint is megvizsgálni, hogy az ACP-országok földrajzi elhelyezkedésük szerint hogyan oszlanak meg a klaszterek között. A mintában szereplő 39 afrikai országból 24 a legkevésbé fejlett klaszterbe került (az ott szereplő ACP-országok mindegyike Afrikában található). A másik elmaradott klaszter hat ACP-országa közül öt Afrikában található. Azaz a 39 afrikai államból 29 (közel 75 százalék) a legkevésbé fejlett országok közé került a vizsgálatba bevont indikátorok alapján. Emellett érdemes azt is kiemelni, hogy öt afrikai ország (többek között Mauritánia, Sao Tomé és Principe, illetve Seychelle-szigetek) a relatíve fejlett, nyitott, EU-érdekeltségü klaszterbe került, és ezen országok a közepes jövedelműek közé tartoznak. Mindez már előrevetíti azt, hogy a Loméi Egyezmények aláírása is hasonló eredményt fog mutatni. 
4.15. táblázat Kedvezményezetti csoport és egyezmények aláírása (országok száma, db)
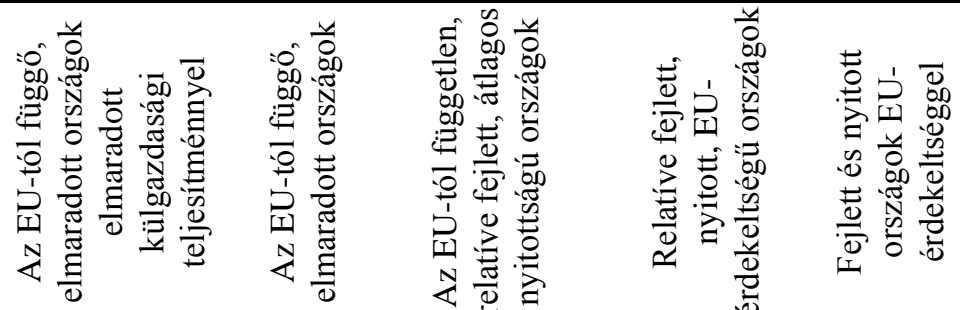

\begin{tabular}{lcccccc}
\hline ACP-ország & 24 & 6 & 11 & 7 & 0 & $\mathbf{4 8}$ \\
\hline Mediterrán ország & 1 & 0 & 2 & 3 & 1 & $\mathbf{7}$ \\
\hline GSP-kedvezmény & 3 & 0 & 15 & 1 & 4 & $\mathbf{2 3}$ \\
\hline Egyiket sem & 4 & 0 & 17 & 4 & 5 & $\mathbf{3 0}$ \\
\hline Lomé I & 23 & 4 & 8 & 3 & 0 & $\mathbf{3 8}$ \\
\hline Lomé II-IV & 1 & 2 & 3 & 4 & 0 & $\mathbf{1 0}$ \\
\hline Összesen & $\mathbf{2 8}$ & $\mathbf{6}$ & $\mathbf{2 8}$ & $\mathbf{1 1}$ & $\mathbf{5}$ & $\mathbf{7 8}$ \\
\hline
\end{tabular}

Forrás: saját szerkesztés

Annak ellenére, hogy a Loméi Egyezmények hatásmechanizmusa alapján egyértelmü fejlődést vártunk volna el és a relatív pozíció megváltozását reméltük, a legkevésbé fejlettnek minősülő klaszterbe került azon országok többsége (több mint 80 százalékuk), melyek már az első egyezményt is aláírták, és azok kerültek kedvezőbb helyzetbe, amelyek egyikhez sem „csatlakoztak”.

Utaltunk arra, hogy a Loméi Egyezmények eredményeit befolyásolhatták - az intézményi háttéren túl - a háborúk is. Ezt a kérdést is megvizsgáltuk, ehhez egy egyszerü módszert használtunk: az UCDP adatbázisából (UCDP/PRIO 2011) összegyüjtöttük az 1975 és 2000 közötti időszakból azokat az éveket, amelyekben az adott országnak fegyveres konfliktusa volt, és ebböl „háborús évek száma” változót generáltunk. Ezek alapjellemzőit néztük meg az öt klaszter vonatkozásában (4.16. táblázat).

4.16. táblázat A háborús évek alakulása az egyes klaszterekben

\begin{tabular}{lccc}
\hline Klaszterek & Átlag & Szórás & N \\
\hline $\begin{array}{l}\text { Az EU-tól függő, elmaradott országok } \\
\text { elmaradott külgazdasági teljesítménnyel }\end{array}$ & 6,250 & 6,878 & 28 \\
\hline Az EU-tól függón, elmaradott országok & 10,167 & 11,268 & 6 \\
\hline $\begin{array}{l}\text { Az EU-tól független, relatíve fejlett, átlagos } \\
\text { nyitottságú országok }\end{array}$ & 5,857 & 8,683 & 28 \\
\hline $\begin{array}{l}\text { Relatíve fejlett, nyitott, EU-érdekeltségü } \\
\text { országok }\end{array}$ & 2,818 & 4,875 & 11 \\
\hline Fejlett és nyitott országok EU-érdekeltséggel & $\mathbf{7 , 6 0 0}$ & 10,807 & 5 \\
\hline Teljes minta & $\mathbf{6 , 0 1 3}$ & $\mathbf{7 , 9 6 3}$ & $\mathbf{7 8}$ \\
\hline
\end{tabular}

Megjegyzés: Szingapúrban a vizsgált időszakban nem volt fegyveres konfliktus.

Forrás: saját szerkesztés

Az eredmények alapján nem lehet egyértelmű következtetést levonni, hiszen a relatíve fejlett, nyitott országok kivételével átlagosan közel azonos számú évet töltöttek el háborúban 
a fejletlen és a fejlett klaszterek. További figyelmet igényel az is, hogy mindegyik klaszterben az átlagnál jóval magasabb a szórás, így nem érdemes messzemenő következtést levonni. Összességében a háborúban állás hosszú távon nem határozta meg az eredményeket, és nem lehet az intézményi háttérhez hasonló konzekvenciákat levonni. Viszont nem foglalkoztunk azzal, hogy a háborús évek a vizsgált időszak (1975-2000) mely szakaszában voltak jelen döntően, ugyanis nem mindegy, hogy az adott ország már az 1970-es években „túlesett” a konfliktusai nagy részén, vagy az az 1990-es években tetőzött. Ez utóbbi ugyanis nagyobb mértékben befolyásolja a 2000-es évek eleji gazdasági adatokat, mint az 1970-es évek eseményei.

\subsubsection{A KÉT IDŐSZAK EREDMÉNYEINEK ÖSSZEHASONLÍTÁSA ÉS KÖVETKEZTETÉSEI}

Az előző két alfejezetben bemutatott eredmények rávilágítottak arra, hogy a mintában szereplő 79 ország relatív helyzete hogyan alakult egymáshoz képest a Lomé-rendszert megelőző és azt követő időszakban. Mivel a Lomé-rendszert követő időszak esetében amellett érveltünk, hogy a főkomponensek mint indikátorok alapján végzett elemzés célravezetőbb, valamint az első időszak vizsgálata alapján is hasonló megérzésünk van, így a két időszak összehasonlítását a fökomponensekkel kapott klaszterek alapján végezzük el. Az eredmények alapján az afrikai országok - melyek később zömében ACP-országok lettek - a legfejletlenebb csoportba kerültek mindkét időszakban; továbbá a Lomé-rendszer utáni időszakban a Loméi Egyezményeket aláíró, ezzel összefüggésben pedig az ACP-országok vannak a legkedvezőtlenebb gazdasági helyzetben a vizsgálatba bevont indikátorok alapján. Mindezzel együtt érdemes megnézni azt, hogy a két időszak között hogyan alakult a relatív pozíció a vizsgált országok körében.

Amennyiben Szingapúrt nem számítjuk, akkor mindkét időszakban öt klaszter kialakítása az ideális, így érdemi különbség e tekintetben nem látható. Viszont a klaszterek közötti mozgás, azaz a relatív pozíció változása vizsgálható. Hiszen a két időszak eredményei meglehetősen hasonlóak: az egyezményeket követő időszak klaszterei jelentésüket tekintve megfeleltethetők az egyezményeket megelőző időszak klasztereinek. Emellett az egyes klaszterek létszámát tekintve is rendkívül hasonló eredményre jutottunk a két időszakban. Annak érdekében, hogy az egyes klaszterek és országok relatív helyzetét össze lehessen vetni a két időszak vonatkozásában, az SPSS outputjában szereplőkhöz, illetve a korábban bemutatottakhoz képest a klasztereket újraszámoztuk azok fejlettségi szintjének megfelelően (4.17. táblázat). A klaszterek (új) számának meghatározása során a hangsúly azon volt, hogy a 
két időszakban az ugyanazon a fejlettségi szinten elhelyezkedő klaszterek ugyanazt a számot kapják, ezzel is kifejezve, hogy a mintabeli relatív helyzetük nem változott.

4.17. táblázat A két időszak klaszterei

\begin{tabular}{lclc}
\hline \multicolumn{1}{c}{ 1. időszak } & $\begin{array}{c}\text { Klaszter új } \\
\text { száma }\end{array}$ & \multicolumn{1}{c}{ 2. időszak } & $\begin{array}{c}\text { Klaszter új } \\
\text { száma }\end{array}$ \\
\hline $\begin{array}{l}\text { Az EU-tól független, } \\
\text { fejlett és nyitott országok }\end{array}$ & 1 & $\begin{array}{l}\text { Fejlett és nyitott országok EU- } \\
\text { érdekeltséggel }\end{array}$ & 1 \\
\hline $\begin{array}{l}\text { Relatíve fejlett, EU- } \\
\text { érdekeltségü országok }\end{array}$ & 2 & $\begin{array}{l}\text { Relatíve fejlett, nyitott, EU- } \\
\text { érdekeltségü országok }\end{array}$ & 2 \\
\hline $\begin{array}{l}\text { Relatíve fejlett és zárt } \\
\text { országok }\end{array}$ & 3 & $\begin{array}{l}\text { Az EU-tól független, relatíve } \\
\text { fejlett, átlagos nyitottságú } \\
\text { országok }\end{array}$ & 3 \\
\hline $\begin{array}{l}\text { Az EU-tól függő́, } \\
\text { elmaradott országok }\end{array}$ & 4 & $\begin{array}{l}\text { Az EU-tól függó, elmaradott } \\
\text { országok }\end{array}$ & 4 \\
\hline $\begin{array}{l}\text { Elmaradott és zárkózott } \\
\text { országok }\end{array}$ & 5 & $\begin{array}{l}\text { Az EU-tól függó, elmaradott } \\
\text { országok elmaradott } \\
\text { külgazdasági teljesítménnyel }\end{array}$ & 5 \\
\hline
\end{tabular}

Forrás: saját szerkesztés

Alapjaiban véve olyan csoportokat kaptunk, amelyek egy-egy szinten helyezkednek el, azaz nem alakultak ki olyan klaszterek, amelyek a másik időszak viszonylatában köztes állapotot jelentenének. Ebből kifolyólag a legegyszerübb megoldás alkalmazható volt az újraszámozást illetően: mindkét időszakban a legfejlettebb klasztert jelöltük 1-essel, míg a legkevésbé fejlettet az 5-össel. Mindezek után a két időszak klasztereit az új - gazdasági fejlettségi hierarchiának megfelelő - számukkal egy koordináta-rendszerben ábrázoltuk (4.5. ábra). A 4.5. ábra ábrán a $45^{\circ}$-os egyenes jelöli azokat a csoportokat (és egyben országokat), amelyek a két időszakban nem változtattak (a mintában elfoglalt) relatív helyzetükön. A klaszterek fejlettségi sorrendjének (azaz növekvő értékének) ismeretében az egyenes alatt elhelyezkedő pontok a két időszak között végbement fejlödést, míg az egyenes felett elhelyezkedő pontok a két időszak közötti visszaesést jelölik. Az áttekinthetőség érdekében az ábrán kizárólag azoknak az országoknak a neveit tüntettük fel, melyek a $45^{\circ}$-os egyenesen kívül esnek, azaz esetükben valamilyen pozícióváltás történt.

A fentiek alapján - Szingapúrt nem számolva - a 78 országból 58 ország esetében változott meg a mintában elfoglalt relatív helyzetük a vizsgálatba bevont indikátorok alapján. Összességében tehát az országok közel háromnegyede (74,36 százaléka) tudott felmutatni javulást vagy visszaesést a többi országhoz képest. Mindez azt jelenti, hogy a vizsgálatban szereplő országok egynegyede ugyanazon a fejlettségi szinten van egymáshoz képest a Lomé-rendszert követő időszakban, mint a kezdeti periódusban. Azonban a korábbi 
klasztereikből kiváló és a $45^{\circ}$-os egyenesen kívül eső országokat érdemes mélyebben megvizsgálni.

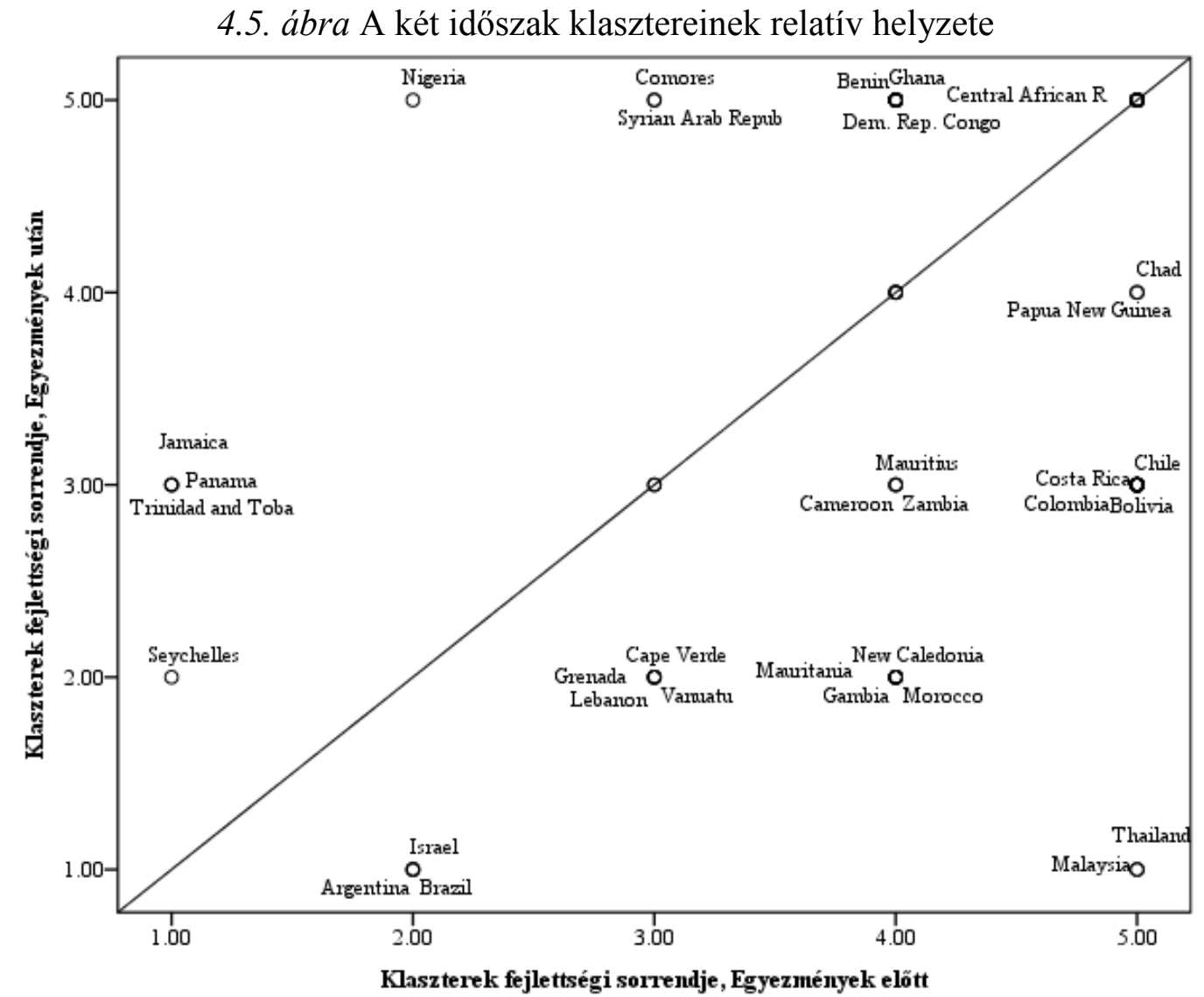

Megjegyzés: a klaszterek számának feloldását a 4.17. táblázat tartalmazza. Az átláthatóság érdekében csak néhány ország szerepel az ábrán azon esetekben, ahol pozícióváltozás volt.

Forrás: saját szerkesztés

Az 58 ország közül többen vannak azok az országok, melyek relatív helyzete javult: 40, pozitív változást felmutató ország emelhető ki, illetve 18 olyan ország található a mintában, melyek mintában elfoglalt pozíciója a vizsgált indikátorok alapján romlott a két időszak között (4.18. táblázat). Viszont a klaszterek jelentéstartalmát figyelembe véve, van egy kérdéses pozíció-változás: az egyezmények előtti 3-as klaszterből az egyezmények utáni 2-es klaszter felé történő mozdulás. Ez esetünkben négy országot érint: Zöldfoki-szigetek, Vanuatu, Libanon és Grenada. A bizonytalanság oka, hogy a nyitottságot vagy a zártságot kell-e kedvezőbbnek tekinteni. Ezen országok az egyezmények előtt relatíve zárt országok voltak, viszont a 2000-es évek elejére már kiemelkedőbb külgazdasági teljesítményt nyújtottak. Összességében viszont relatíve fejlettek maradtak: azaz se nem a legfejlettebbek, se nem a legalmaradottabbak, de fejlettségi szintjük inkább a fejlettebb klaszterek felé tendál. Összességében az 58 klasztertagságot váltó ország közül 36-nak egyértelműen javult, 18-nak egyértelműen romlott a minta országaihoz képesti relatív helyzete, négyről pedig nem lehet 
biztosat állítani - ha a nyitottságot kedvezőbbnek ítéljük meg, mint a zártságot, akkor kedvező változás következett be, ellenkezö esetben itt is romlásról beszélhetünk, de akár változatlannak is tekinthetjük. Viszont összességében pozitívnak ítélhetjük meg a két időszak közötti változást, hiszen a mintabeli országok közel fele relatíve kedvezőbb pozícióval rendelkezik a kezdeti időszakhoz képest.

4.18. táblázat A pozíciót váltó országok

\begin{tabular}{|c|c|c|}
\hline Változás & Klaszter & Országok \\
\hline \multirow{7}{*}{$\stackrel{5}{3}$} & $2 \rightarrow 1$ & Argentína, Brazília, Izrael \\
\hline & $3 \rightarrow 2$ & Grenada, Libanon, Vanuatu, Zöldfoki-szigetek \\
\hline & $4 \rightarrow 3$ & Kamerun, Mauritius, Zambia \\
\hline & $4 \rightarrow 2$ & $\begin{array}{l}\text { Gambia, Marokkó, Mauritánia, Uj-Kaledónia, Sao Tomé és Principe, } \\
\text { Tunézia }\end{array}$ \\
\hline & $5 \rightarrow 4$ & Csád, Pápua Uj-Guinea \\
\hline & $5 \rightarrow 3$ & $\begin{array}{l}\text { Bolívia, Chile, Costa Rica, Ecuador, Egyiptom, El Salvador, Fülöp- } \\
\text { szigetek, Guatemala, Guyana, Haiti, Honduras, Kolumbia, Mozambik, } \\
\text { Nicaragua, Paraguay, Szamoa, Sri Lanka, Suriname, Uruguay }\end{array}$ \\
\hline & $\underline{5} \rightarrow \underline{1}$ & Malajzia, Thaiföld \\
\hline \multirow{5}{*}{ 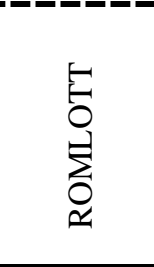 } & $1 \rightarrow 2$ & Seychelle-szigetek \\
\hline & $1 \rightarrow 3$ & Jamaica, Panama, Trinidad és Tobago \\
\hline & $2 \rightarrow 5$ & Nigéria \\
\hline & $3 \rightarrow 5$ & Comore-szigetek, Szíria \\
\hline & $4 \rightarrow 5$ & $\begin{array}{l}\text { Benin, Közép-afrikai Közt., Kongói Dem. Közt., Ghána, Bissau- } \\
\text { Guinea, Libéria, Madagaszkár, Niger, Szenegál, Sierra Leone, Togo }\end{array}$ \\
\hline
\end{tabular}

Megjegyzés: a félkövér betüvel szereplö országok az ACP-csoportba tartoznak.

Forrás: saját szerkesztés

Az eredmények ellenőrzése érdekében megvizsgáltuk, hogy a változást felmutató országok jövedelmi szintje (alacsony vagy közepes jövedelmủ) alapján látható-e valamilyen tendencia. Azon államok, amelyek relatív helyzete javult a két időszak között, többnyire a közepes jövedelmű országok közé tartoznak. Ugyan Csád a legkevésbé fejlett országok egyike, viszont ha megnézzük, továbbra is az egyik legfejletlenebb klaszterben maradt, így ez egyáltalán nem torzító tényező. Két ország esetén viszont érdekes eredménnyel szembesültünk: ez pedig Haiti és Mozambik, hiszen mindkettő a legkevésbé fejlett országok közé tartozik. Ennek oka lehet a komplex elemzési módszer használata és nem az egy indikátoron alapuló következtetések levonása. Valamint e két ország mintában elfoglalt helyét látjuk, ami nem tartalmazza az összes fejlődő országot. Emellett, azon országok, melyek relatív helyzete romlott, zömében az alacsony jövedelmü országok közé tartoznak. Kiemelendő, hogy a relatív helyzet megváltozása (mind a javulás, mind a romlás oldalán) majdhogynem ugyanazon a szinten történt: mindkét időszak fejlett klaszterei között, illetve mindkét időszak fejletlen klaszterei között történt mozgás, és nem jellemző a „nagy ugrás”. 
A dolgozat témája szempontjából az is fontos, hogy a pozitív (illetve a negatív) eredményt elért országok közül melyek tartoznak az ACP-országok közé. Áttekintve az országokat, érdekes eredmény állapítható meg. Az egyértelmüen pozitív eredménnyel bíró 36 országból 13 tartozik az ACP-országok közé: ennyi, az EU által kiemelten kezelt ország tudott javítani a mintában elfoglalt relatív helyzetén. Közülük nyolcan tudtak legalább „két klaszternyit" elörelépni. Emellett a 18 visszaesést mutató ország közül szintén 16 tartozik az ACP-országok közé, azaz azon országok, melyek relatív pozíciója romlott a két időszak között, 89 százalékban az ACP-országok közé tartoznak. Érdekes az, hogy az egyezmények előtti 4-es klaszterből az egyezmények utáni 5-ös klaszterbe kerülő országok mindegyike (összesen 11) az ACP-országok közé tartozik! Összességében tehát a mintában szereplő 48 ACP-ország közül 13 tudott javítani a relatív helyzetén, 16 rontott a pozícióján, míg 19 ország esetében nem történt változás. Ebből kifolyólag az országok eltérő módon tudták kihasználni a Loméi Egyezmények adta lehetőségeket: egyértelműen pozitív változásról azonban csak a mintában szereplő ACP-országok negyede esetén beszélhetünk, míg háromnegyedük esetében nem történt kedvező változás.

Hangsúlyozandó, hogy ezek a vizsgálatok mindössze arra mutatnak rá, hogy a minta országainak relatív helyzete hogyan alakult egymáshoz képest a két időszakban. Annak érdekében, hogy megállapítsuk, történt-e szignifikáns változás az egyes országok, illetve országcsoportok gazdasági mutatói között a két időszakban, a két időszak átlagait hasonlítottuk össze. A két összefüggő minta elemzése nem-parametrikus teszt ${ }^{80}$ (Wilcoxonteszt) segítségével történt (4.19. táblázat). A három kedvezményezett-csoportban bár különböző párok közötti különbség tekinthető szignifikánsak, a közös változók esetében az elöjelek ugyanazok.

A Wilcoxon-teszt eredményei szerint az EU szerepe szignifikánsan csökkent az ACP országok exportjában és importjában is, valamint az ACP országok részesedése az EU összkereskedelméből szintén szignifikánsan alacsonyabb, mint volt korábban, így az ACPországok térvesztése - a Loméi Egyezmények ellenére - egyértelmüen látható az EU-val folytatott kereskedelmet illetően. Hasonló csökkenés a többi csoportban is megfigyelhető, bár ott egy-egy terület mentesült ezek alól. Ugyan a külföldi tőke esetében mindenütt szignifikáns és pozitív irányú változás figyelhető meg, azonban az FDI folyóáron szerepel, így nem feltétlenül valós növekedésről van szó, annak ellenére, hogy az 1980-as évektől kezdve

\footnotetext{
${ }^{80}$ T-teszt nem alkalmazható a kis elemszámú minta, illetve a változókkal szembeni normális eloszlás követelményének nem teljesülése miatt.
} 
jelentős mértékben megnőtt a külfölditőke-forgalom a világon. Érdekes továbbá az is, hogy bár a két időszak között szignifikánsan csökkent a mezőgazdaság részaránya a gazdasági kibocsátásból, valamint a mezőgazdasági foglalkoztatottak aránya az ACP-országokban, a korábbi vizsgálati eredmények alapján azonban még mindig jelentős gazdasági szektornak számít ebben az országcsoportban (a többi országhoz képest), és az ipar szignifikáns növekedése sem tudta ellensúlyozni.

4.19. táblázat A Wilcoxon-teszt eredményei (p-értékek)

\begin{tabular}{|c|c|c|c|c|}
\hline Indikátor & Teljes minta & $\begin{array}{c}\text { ACP- } \\
\text { országok }\end{array}$ & $\begin{array}{l}\text { Mediterrán } \\
\text { o. }\end{array}$ & GSP \\
\hline az EU részesedése az ország exportjából & $(-) 0,000$ & $(-) 0,000$ & 0,398 & (-) 0,002 \\
\hline az EU részesedése az ország importjából & $(-) 0,000$ & $(-) 0,000$ & $(-) 0,043$ & $(-) 0,000$ \\
\hline $\begin{array}{l}\text { az ország részesedése az EU harmadik } \\
\text { országokkal folytatott exportjából }\end{array}$ & (-) 0,000 & (-) 0,000 & 0,398 & $(-) 0,014$ \\
\hline $\begin{array}{l}\text { az ország részesedése az EU harmadik } \\
\text { országokkal folytatott importjából }\end{array}$ & (-) 0,000 & (-) 0,000 & 0,398 & 0,317 \\
\hline export/GDP & $(+) 0,000$ & 0,121 & 0,176 & (+) 0,002 \\
\hline külkereskedelmi mérleg & 0,088 & 0,095 & 1,000 & 0,493 \\
\hline egy fơre jutó beáramló külföldi tőke & $(+) 0,000$ & $(+) 0,000$ & $(+) 0,018$ & $(+) 0,000$ \\
\hline $\begin{array}{l}\text { a beáramló külföldi töke aránya a GDP- } \\
\text { ben }\end{array}$ & (+) 0,000 & (+) 0,001 & (+) 0,018 & (+) 0,001 \\
\hline GDP/fö & $(+) 0,000$ & 0,222 & 0,128 & (+) 0,000 \\
\hline mezógazdaság/GDP & $(-) 0,000$ & $(-) 0,029$ & $(-) 0,043$ & $(-) 0,000$ \\
\hline ipar/GDP & 0,127 & $(+) 0,036$ & 0,866 & 0,864 \\
\hline szolgáltatások/GDP & $(+) 0,000$ & 0,091 & 0,176 & $(+) 0,000$ \\
\hline $\begin{array}{l}\text { mezógazdasági foglalkoztatottak aránya } \\
\text { a teljes népességen beül }\end{array}$ & (-) 0,000 & (-) 0,000 & (-) 0,018 & $(-) 0,000$ \\
\hline mezógazdasági termelékenység & 0,458 & 0,538 & 0,237 & 0,199 \\
\hline
\end{tabular}

Megjegyzés: zárójelben a változás iránya a két időszak között. A szignifikáns változás szerepel sötét háttérrel.

Forrás: saját szerkesztés

Kiemelendő, hogy a mezőgazdasági termelékenység a két időszak között nem változott szignifikáns mértékben, és az egy főre jutó GDP is csak a teljes minta, illetve a GSPországok körében mutat szignifikáns növekedést. Mindezek azt mutatják, hogy bár vannak kedvező jelek, azonban ezek nem tekinthető olyan mértékünek, hogy az országok relatív pozíciója jelentős mértékben megváltozzon egymáshoz képest, így a klaszterelemzés és a hipotézisvizsgálat eredményei alapján az 1. hipotézist elvetjük. Azaz az eredmények alapján nem elfogadható az az állítás, hogy az ACP-országoknak a Loméi Egyezmények beavatkozási területeihez köthető gazdasági teljesítménye a Lomé-rendszert követő időszakban kedvezőbb az egyezményeket alá nem író fejlődő országok gazdasági teljesítményéhez képest, annak ellenére, hogy 13 ország relatív pozíciója kedvezőbb lett a mintán belül.

A Loméi Egyezményekhez kötődően fogalmaztuk meg a 2. hipotézisünket is: A Loméi Egyezmények beavatkozási területei alapján meghatározott gazdasági indikátorok 
figyelembe vételével a heterogén ACP-országok több, egymástól jól elkülöníthető homogén csoportra bonthatóak. A 2. hipotézis az empirikus vizsgálat eredményei alapján elfogadható, hiszen egyértelműen vannak olyan ACP-országok, amelyek kedvezőbb feltételekkel rendelkeznek, viszont hangsúlyozzuk, hogy egyik sem tartozik a kiemelkedően fejlett országok közé. Relatív fejlettségi színvonalukat illetően meglehetősen közel helyezkednek el egymáshoz képest. Ez a - picinyke - különbség már a Loméi Egyezmények előtti időszakban is megfigyelhető.

A dolgozat ezen fejezetében bemutatott empirikus elemzés több ponton is eltér a kutatásunk során megismert szakirodalmi elemzésekben található vizsgálatoktól, és így a Loméi Egyezmények lehetséges hatásairól átfogóbb képet nyerhettünk. A kutatás fontosságát az alábbi tényezőkkel emelhetjük ki:

- A szakirodalmi elemzések többnyire a partnerországok közötti kereskedelem alakulásának vizsgálatára helyezik a hangsúlyt (például Persson és Wilhelmsson 2006). Ezzel szemben az itt bemutatott vizsgálat szélesebb körü, és a Loméi Egyezmények beavatkozási területei alapján átfogóbban elemeztük az egyezmények lehetséges következményeit.

- Többnyire olyan kutatások születtek, amelyek mindössze leíró statisztikai módszerek alkalmazásával és a kereskedelmi eredmények összehasonlításával vonnak le következtetéseket a Lomé-rendszer eredményeire vonatkozóan (például Babarinde és Faber 2004, Cosgrove 1994), de az ökonometriai elemzések is elsősorban a kereskedelem alakulását tekintik elsődleges vizsgálati céljuknak. Ezeket az eredményeket az előzőekben ismertetett vizsgálattal pontosítani tudtuk.

- A kutatás során megismert elemzések csak a lehetséges következmények feltárásával foglalkoztak, és az országok relatív pozícióját nem vizsgálták. Ez utóbbinak a bemutatására viszont elemzésünk során kísérletet tettünk.

- Az országok relatív pozíciójának vizsgálata nem csak a szerint történt, hogy az ország az ACP-csoportba tartozik-e, hanem figyelembe vettük, hogy mely Loméi Egyezményt írta alá először, illetve, hogy melyik kedvezményezetti csoportba tartozik, amennyiben nem ACP-ország.

- Az eddigi tanulmányok többnyire a folyamatot elemezték, és nem foglalkoztak a Loméi Egyezményeket megelőző és követő időszak állapotának összehasonlításával, holott ennek alapján számos következtetés levonható. 
Empirikus vizsgálatunk - tulajdonképpen a szakirodalomban fellelhető, többnyire elméleti fejtegetésekkel összhangban - összességében kedvezőtlen eredményeket mutat, és úgy tünik, hogy a Loméi Egyezmények aláírása nem jelentett előnyt az ACP-országok többségének, amelynek elsődleges oka az intézményi hiányosságokban keresendő. Mindez viszont nem indokolja azt, hogy az egyezmények teljesen feleslegesek lettek volna: valószínüleg ezek az országok az egyezmények által biztosított preferenciák nélkül kedvezőtlenebb helyzetben lennének, és nagyobb mértékben csökkent volna a két fél közötti kereskedelem. Elemzésünk eredményei viszont rávilágítanak arra, hogy a szabad piacra lépés önmagában nem jelent fejlődést, csak lehetőséget, ha az országon belül még számos akadály található (elsősorban a fejletlen - tágan értelmezett - infrastruktúrára kell gondolnunk). Ahogyan Curran, Nilsson és Brew (2008, 531. o.) fogalmazott tanulmányukban: „Ha a piacra jutás a fejlödés kulcsa lett volna, az ACP-országok a fejlödö világ leggazdagabb országai között lennének.” A következőkben ennek megfelelően azokat a legnyilvánvalóbb tényezőket tekintjük át, melyek a Loméi Egyezmények alacsony hatékonyságát eredményezték.

\subsection{A LOMÉI EGYEZMÉNYEK KUDARCÁNAK LEHETSÉGES OKAI}

Eredményeink szerint az ACP-országok többségének relatív helyzete nem változott a mintában szereplő országokhoz képest a Loméi Egyezményeket követő időszakban az egyezmények előtti állapothoz viszonyítva. Mivel a legtöbb ország 25 éven keresztül élvezhette ezeket a kedvezményeket, a relatív pozícióváltás elmaradása arra utal, hogy az egyezményekkel biztosított kereskedelmi és egyéb gazdasági kedvezmények nem tekinthetők eredményesnek. Ez az eredménytelenség különösen annak fényében elgondolkodtató, hogy az afrikai országok számítanak az EU fejlesztési politikájának fó kedvezményezettjének, több segélyt és kedvezményt kaptak, mint bármely más fejlődő ország (Abass 2004, Bjornskov és Krivonos 2001, Farrell 2005, Kebonang 2007). Ennek ellenére ezek az országok a többi fejlődő országhoz képest hátul „kullognak”. Így jogosan merül fel a kérdés, hogy milyen okokra vezethető vissza, hogy az ACP-országok a feléjük nyújtott egyoldalú (viszonosság nélküli) kedvezmények ellenére nem tudtak jelentős gazdasági növekedést és fejlődést produkálni. A dolgozat jelen fejezete ezekre a kérdésekre próbál meg válaszokat adni.

Hurt (2003) cikkében felhívja arra a figyelmet, hogy az Európai Unió fejlesztés területén végzett tevékenységét a világgazdasági tendenciákkal együtt kell vizsgálni. A 
szerzővel egyetértve így a dolgozat ezen fejezete nemcsak azokat az országon belüli tényezőket fejti ki, melyek a fejlődés akadályai lehettek, hanem kitér azon világgazdasági folyamatokra is, melyek hatással lehettek a fejlesztések kimenetelére. Ennek alapján a sikertelenség okai külső és belső tényezők összességeként határozható meg (4.20. táblázat). A külső tényezők azon világgazdasági, országon kívüli folyamatokat takarják, melyeket az ország nem tud befolyásolni, míg a belső tényezők az országon belüli hiányosságokat jelentik. Ezen tényezők meghatározása elsősorban Babarinde és Faber (2004), Bjornskov és Krivonos (2001), Borrmann et al (2007), Cosgrove (1994), Degnbol-Martinussen és Engberg-Pedersen (2005), EC (1996), Farrell (2005), Hurt (2003), Oyewumi (1991), Parfitt (1996), Santos (1999) és Whiteman (1998) elméleti fejtegetéseinek összegzése alapján történt, amit kiegészítettünk egyéb faktorokkal. Hangsúlyozandó, hogy egy igen összetett folyamatról van szó, így nem lehet minden okot pontosan meghatározni, ebből következően csak kísérlet történik azoknak a - talán legszembetünőbb - folyamatoknak a feltárására.

\begin{tabular}{|c|c|}
\hline Külső tényezők & Belső tényezők \\
\hline $\begin{array}{c}\text { Fajlagos nyersanyagszükséglet } \\
\text { csökkenése }\end{array}$ & Infrastruktúra kiépítetlensége \\
\hline Kis tigrisek megjelenése & Fizikai és humán tóke fejletlensége \\
\hline Közép- és Kelet-Európa rendszerváltása & $\begin{array}{c}\text { Beruházások és megtakarítások alacsony } \\
\text { szintje }\end{array}$ \\
\hline $\begin{array}{c}\text { GATT-egyezmények, preferenciák } \\
\text { eróziója }\end{array}$ & Pénzügyi szektor fejletlensége \\
\hline Egységes belsó piac kialakulása & Korrupció magas szintje, burjánzása \\
\hline Aszimmetrikus függőség & Háborúk, belső konfliktusok \\
\hline $\begin{array}{l}\text { Csökkenō EU-s támogatás } \\
\text { (Stabex, Sysmin) }\end{array}$ & Intézményrendszer fejletlensége \\
\hline FDI elmaradása & \\
\hline
\end{tabular}

\subsubsection{A SIKERTELENSÉG LEHETSÉGES KÜLSŐ OKAI}

A világgazdasági változások, azaz a külső tényezők elsősorban a két fél közötti kereskedelem alakulására lehetett hatással, hiszen az iparfejlesztés és a diverzifikáció inkább belügynek számít (kevésbé kiszolgáltatott a világgazdasági eseményeknek), és meg (nem) valósulása elsősorban országon belüli tényezőkkel magyarázható. Az Európai Unió tagországaiban a fajlagos nyersanyag-szülkséglet jelentősen visszaesett a gazdasági szerkezet jelentős átalakulása következtében: a szolgáltatások, a kevésbé nyersanyag-igényes (például high-tech) iparágak kerültek előtérbe (Balázs 2002, Babarinde és Faber 2004) ezáltal tulajdonképpen hiába volt szabad a piacra lépés az ACP-, így a fekete-afrikai országoknak, ha nem volt kereslet az általuk exportálni képes termékek iránt. 
A kereskedelmet tekintve egyértelmüen kimutatható, hogy az Európai Unió figyelme, stratégiai fókusza más országok, térségek felé irányult: Kelet-Közép-Európa és az ázsiai újonnan iparosodott országok lettek stratégiailag fontos területek (Farrell 2005). Az 1980-as évekre több dinamikusan fejlődő ázsiai ország (pl. Hongkong, Szingapúr, Tajvan, Thaiföld „tigrisek”) korábbi években megtörtént világgazdasági nyitásának és a nemzetközi kereskedelembe való bekapcsolódásának hatása érezhetővé vált, és részesedésük az EUimportból és annak exportjából 20 év alatt megduplázódott. Ezek az országok olcsó, és ezzel egyidejüleg minőségi termékekkel tudtak megjelenni az európai piacokon, és képesek voltak a versenyben (hatékonyan) részt venni.

A szovjet blokk szétesése és a kelet-közép-európai országok rendszerváltása után (az 1990-es évektől kezdve) az Európai Unió gazdasági (így kereskedelmi) lehetőségei megnőttek ezen államok irányában. Úgy tünik, ezt ki is használta, hiszen ezen országcsoport részesedése az EU export és import oldalán is megduplázódott 1990-ről 2000-re: az EU összimportjából való részesedésük 5,4 százalékról 9,9 százalékra emelkedett, míg az összexportból való részesedésük 6,2 százalékról 13,2 százalék lett ugyanezen időszakot vizsgálva (EC 2008e). De nemcsak a kereskedelem tekintetében kerültek előtérbe, hanem a segélyeket és a beruházásokat tekintve is, hiszen az EU az ACP-országok helyett ezekbe az országokba csoportosította át (a felzárkózást segítő) segélyeit és beruházásait (Cosgrove 1994, Parfitt 1996). Másrészt a biztonság megőrzése érdekében is fontos volt, hogy ezeket az országokat „,szemmel tartsa”, így Közép-Európa az európai külpolitika fontos célpontjává vált (Santos 1999).

A GATT Uruguayi Fordulója (1986-1994) során elfogadott néhány egyezmény hátrányosan érintette a fejlődő, köztük az ACP-országokat - ezek közül két példát emelnénk ki. ${ }^{81} \mathrm{Az}$ ipari államok általános vámkedvezményeket irányoztak elő a fejlődő országok számára, így az ezen országok számára megnyílt kedvezőbb környezet következtében megnőtt a világpiacon a verseny (Borrmann et al 2007, Collier et al 1997, Santos 1997), azaz az ACP-országok mellett más országok is kedvező piacra jutási feltételekhez jutottak, és a nagyobb versenyben az ACP-országok háttérbe szorultak. Emellett az 1990-es évek elején elfogadott szellemi tulajdonjogra vonatkozó szabályozás (TRIPS ${ }^{82}$ ) nemcsak a közegészségügyben és a gyógyszerekhez való hozzáférésben okoz gondot a fejlődő országokban (Udvari 2010a), hanem gátolja azokat abban, hogy a technológiát a fejlett

\footnotetext{
${ }^{81}$ Az Uruguayi Forduló eredményeit, egyezményeit lásd részletesen Somai (1997) tanulmányában.

${ }^{82}$ Trade-Related Aspects of Intellectual Property Rights
} 
országoktól lemásolják (ahogy ezt korábban megtehették), és a saját színvonalukon használják (Farrell 2005, Somai 1997).

A WTO egyre több területre kiterjedő szabályozásával egy időben indult meg az a folyamat, mely az EK-ban a belső piac kialakulását irányozta elő. Az így kialakult, közösségi szinten érvényes szabályozás és a különböző, meglehetősen szigorú (fogyasztóvédelmi, csomagolási, környezetvédelmi, minőségi stb.) előírások „elriaszthatták” az ACP-országokat (Cosgrove 1994), hiszen nem, vagy csak nagy költségek árán tudtak (volna) megfelelni ezeknek a szabályoknak. Mindezek mellett meg kell említeni a relatíve szigorú származási szabály elvét is: az ACP-országok exportjában a hozzáadott érték legalább 50 százaléka ACP-országban kell létrejönnie (Parfitt 1996).

Továbbá az EU fejlesztési politikáját, köztük a Loméi Egyezményeket is kritizálják, hiszen minden más tényezőt figyelembe vettek a segélyek szétosztásakor, csak a szegénységet nem (Degnbol-Martinussen és Engberg-Pedersen 2005). Valamint a szerzők kiemelik azt is, hogy az EU a saját érdekeit követte, hiszen az ACP-térséggel kialakított kapcsolatával akarta biztosítani egyrészt a nemzetközi szerepének növekedését, másrészt a saját nyersanyagigényének kielégítését is, ami a Loméi Egyezmények sikertelenségéhez vezetett. A Stabex és Sysmin rendszerek szerepe a gazdaság stabilizációja lett volna, viszont a támogatások kifizetése lassú volt, alacsony összegekkel, és a diverzifikációt akadályozta (hiszen ha támogattak egy területet a csökkenő bevételek ellenére, nem volt szükség más jellegü gazdaságfejlesztésre), ezzel együtt pedig a két rendszer nem ösztönző, hanem torzító eszközöket tartalmazott (Collier et al 1997, Degnbol-Martinussen és Engberg-Pedersen 2005).

Bár a Loméi Egyezmények számos esetben sokkal kedvezőbb feltételeket biztosítottak az ACP-országoknak, egy nagy hátulütője is volt, ami egyben a kedvezményezett országok fejlődésének akadályának is tekinthető: a kedvezmények következtében erős (aszimmetrikus) függőség alakult ki az ACP-országok és az Európai Unió között (Balázs 2002, Bjornskov és Krivonos 2001, Farrell 2005, Whiteman 1998). Az ACP-országok nagymértékben függtek az EU részéről érkező támogatásoktól, kereskedelmi kedvezményektől, és ennek következtében az 1990-es évek elején bekövetkezett világgazdasági változások (szovjet blokk szétesése, ázsiai országok megerősödése, az európai belső piac kialakulása) után olyan problémákkal találták szembe magukat, melyekre nem tudtak megfelelő módon reagálni. A kedvezményezettnek számító afrikai, karibi és csendesóceáni fejlődő országok nem tudták felvenni a versenyt az új versenytársakkal, nem tudtak 
tömegesen megfelelni a belső piacon érvénybe lépő szigorúbb szabályozással szemben. Mindezek ellenére az EU fontos kereskedelmi partnere maradt ezen országoknak, míg az ACP-országok egyre kisebb szerepet játszanak az EU harmadik országokkal folytatott kereskedelmében (Fontaine et al 2008, Hinkle és Schiff 2004). Azonban mindennek a másik oldalát is figyelembe kell venni: a Loméi Egyezmények 25 év alatt tulajdonképpen érdemi változást nem eredményeztek az abban részt vevő, legtöbb fejlődő országban: a diverzifikáció hiánya még ma is több országot jellemez (Babarinde és Faber 2004), és ezen országok összexportjának 60\%-át mindössze tíz termék teszi ki (Moreau 2000).

\subsubsection{A SIKERTELENSÉG LEHETSÉGES BELSŐ OKAI}

A Loméi Egyezmények kétségbe vonható hatékonyságának vizsgálatakor nem szabad kizárólag a külső tényezőket, a világgazdaságban végbement változásokat, a különböző térségek stratégiai érdekeinek eltolódását okolni, hiszen maguk a fejlődő országok is gátjaik lehetnek saját fejlődésüknek - azaz a fejlődési lehetőségeiket akadályozó belső (gazdaságitársadalmi-politikai) tényezőket nem tudták megfelelően kezelni.

Az Európai Bizottság 1996-os, az EU és az ACP-országok kapcsolatát taglaló Zöld Könyve elsősorban ezekre a tényezőkre (nem pedig a külgazdasági változásokra) vezeti vissza a Loméi Egyezmények sikertelenségét a részt vevő országok fejlődésének területén. A Zöld Könyv kiemeli, hogy számos, a fejlődés tekintetében nélkülözhetetlen tényező hiánya volt az akadálya annak, hogy a Loméi Egyezmények kedvezményeit élvező ACP-országok hasznot tudjanak húzni a kereskedelmi kedvezményekből adódó előnyökből, a különböző területeken történő együttműködésekből (EC 1996). Ezen kritikus tényezők között az említett dokumentum többek között az infrastruktúrát, a vállalkozókészség, a fizikai és humán tőke alacsony színvonalát, a beruházások és megtakarítások alacsony szintjét, valamint a fejletlen pénzügyi szektort említi meg; valamint kiemeli, hogy a legtöbb részt vevő ország olyan termékek kereskedelmétől, exportjától függ, amelyek világpiaci ára jelentősen ingadozik (EC 1996). A Zöld Könyvben ugyan nem szerepel, de nem feledkezhetünk meg arról sem, hogy az ACP-országok egy részében (például Csád, Ruanda, Szudán, BissauGuinea) belső háborúk is dúltak ebben az időszakban, melyek megakadályozták azt, hogy egyáltalán ki tudják használni az adódó lehetőségeket. ${ }^{83}$ Csak Afrikában 1970 és 1988 között 3-8 fegyveres konfliktus, polgárháború volt, amelyek ráadásul több évig tartottak (Hoeffler 2008). Ez nem csak azt jelenti, hogy maguk a háborús helyzetű országok nem tudtak élni a

\footnotetext{
${ }^{83}$ A háborúk, fegyveres konfliktusok negatív hatásait a dolgozat 2.3.1. fejezetben már részleteztük.
} 
lehetőségekkel, és a saját gazdaságukat is romba döntötték, hanem az EU sem támogatott kétes helyzetü országokat.

Oyewumi (1991) cikkében ezek mellett a Loméi Egyezmények vizsgálatakor kiemeli azt is: komoly problémát jelentett az is, hogy a Stabex és Sysmin gazdaságstabilizációs rendszerből származó kompenzációt a kormányok kapták meg, nem pedig közvetlenül a termelőknek juttatták el - és a korrupcióra gondolva ez a pénz könnyen elveszhetett.

Ezek a tényezők teljesen összhangban vannak a dolgozat 2.3. alfejezetében bemutatott, a fejlődő országok elmaradottságához vezető tényezőkkel - ennek is betudható az, hogy csak néhány ország teljesített sikeresen, azonban összességében (magát az ACP-országok csoportját tekintve) elég rossz az eredmény (Moreau 2000). Mindez azt jelenti, hogy fejlődés csak azokban az országokban volt tapasztalható, amelyek a kedvezmények hatékony kihasználása érdekében gazdaságpolitikájukban, intézményi hátterükben is alkalmazkodtak.

Összességében ugyan az Európai Unió fejlesztési politikája egyedi képet mutat, és már az 1970-es évek óta viszonosság nélküli kedvezményeket biztosított számos fejlődő ország számára, az nem tekinthető eredményesnek. A Loméi Egyezményeket megelőző és követő időszakok elemzése és összevetése alapján a konvenciókkal biztosított kereskedelmi és gazdasági preferenciák nem voltak olyan jelentősek, hogy érdemben megváltozzon a vizsgálatban szereplő fejlődő országok relatív helyzete (a vizsgálatban szereplő indikátorok alapján). A sikertelenségnek külső és belső okait is felhoztuk. Ennek fényében pedig kérdéses, hogy az EU az ezredforduló utáni tevékenységében miként igyekszik ezeken a tényezőkön változtatni, és hogyan próbálja kiiktatni a lehetséges hibákat. A dolgozat következő fejezetében ezeket a kérdéseket elemezzük. 


\section{AZ EURÓPAI UNIÓ FEJLESZTÉSI POLITIKÁJA AZ EZREDFORDULÓ ÓTA}

A Loméi Egyezmények után új fejezet kezdődött az Európai Unió fejlesztési politikájában. Ennek elsődleges okai a nemzetközi környezet nyomásában, a Loméi Egyezmények WTO szabályaival (legnagyobb kedvezmény elvével) ellentétes létében, a Loméi Egyezmények sikertelenségében, illetve a fejlődő országok új igényeiben keresendők. A dolgozat ezen fejezetében e változásokat tekintjük át: bemutatjuk, hogy a nemzetközi kereskedelem szerepét a fejlödésben, fejlesztésben hogyan ítéli meg az EU a Loméi Egyezmények tapasztalatai után és az ezredforduló óta, kitérünk a Cotonou-i Egyezményre és a Gazdasági Partnerségi Megállapodásokra. Ezután megnézzük azt, hogy a dolgozat korábbi, 3.3. fejezetében ismertetett Aid for Trade hogyan illeszkedik az Európai Unió fejlesztési tevékenységébe, arra helyezve a hangsúlyt, hogy mennyiben javíthatja a fejlesztési politika hatékonyságát. Empirikus úton vizsgáljuk, hogy az EU-ból érkező Aid for Trade támogatások milyen mértékben növelik meg a fogadó országok EU-val folytatott kereskedelmét.

\subsection{AZ EU ÁLLÁSPONTJA A NEMZETKÖZI KERESKEDELEM SZEREPÉVEL KAPCSOLATBAN}

Ahogy arra már kitértünk, a korábbi felfogás, miszerint a kereskedelem a gazdasági növekedés motorja (Ekholm és Södersten 2002, Freund és Bolaky 2008), ma már kibövült azzal, hogy a nemzetközi munkamegosztásban való részvétel a fejlödés és a szegénység csökkentésének egyik eszköze lehet (Hallaert és Munro 2009), ugyan egyikre vonatkozóan sincs egyértelmü empirikus bizonyíték, sőt, ahogy a korábbi fejezetekben rámutattunk: a kapcsolat megléte több tényezőtől függ. Az Európai Unió is - a dolgozat 3.2.4. fejezetében bemutatott nemzetközi szervezetekhez hasonlóan - ezen az állásponton van, és már nyíltan úgy vallja, hogy a kereskedelem a gazdasági növekedés mellett a fejlödés hajtóereje is, ennek ismeretében pedig a Millenniumi Fejlesztési Célok megvalósításának egyik eszközeként tekint a kereskedelemre (EC 2008a). Mindez több EU-s kiadványban, dokumentumban nyomon követhetö.

A 2005-ben napvilágra került Európai Fejlesztési Konszenzus (The European Consensus on Development) az első olyan dokumentum, amely a tagállamok és a Közösség közös vízióját tartalmazza a fejlesztési politikát illetően (EC 2006b). Ebben a dokumentumban is megjelenik, hogy a fejlesztést nem lehet elkülönült tevékenységként kezelni, és más politikákkal együtt kell figyelembe venni. Ennek hivatalos EU-s (háttér) dokumentuma a 2005-ös bizottsági kiadású Politikák fejlesztési célú koherenciája (EC 
2005b). E dokumentum szerint a fejlesztési politika megvalósulását nem akadályozhatja más közösségi politika, valamint a fejlesztési együttmüködés megvalósulása más politikák célkitüzéseinek elérését is segíti. Dolgozatunk témája szempontjából kiemelt jelentőséggel bír az az állítás, miszerint „,...) az EU elkötelezett arra, hogy a fejlesztési együttmüködés határain túlra tekintsen, és mérlegelje azt a kihívást, hogy a nem segély célú politikák hogyan tudják segiteni a fejlődő országokat az MDG-k elérésében” (EC 2005b, 4. o.). Ezt figyelembe véve 12 olyan területet határoztak meg, melyek hatással lehetnek a fejlesztési együttmüködésre (EC 2005b): kereskedelem, környezet, klímaváltozás, biztonság, mezőgazdaság, halászat, szociális politika, migráció, kutatás, információs technológia, energia és közlekedés. Ezek közül csak a dolgozatunkban kiemelten kezelt kereskedelmet és az ahhoz kötődő állításokat részletezzük.

A politikák összehangolását taglaló dokumentum szerint a közösségi kereskedelempolitika révén segítik a dohai forduló fejlesztésorientációjának megvalósulását, valamint az ACP-országokkal kötött Gazdasági Partnerségi Megállapodások $^{84}$ is a fejlődést igyekeznek szolgálni. Továbbá az EU azon lesz, hogy a kereskedelmet a fejlesztési stratégiáiba integrálja, valamint szükség esetén támogatja a fejlődő országokat belső reformjaik véghezvitelében. Így az EU egyértelműen a kereskedelemre helyezi a hangsúlyt, amikor fejlesztésről van szó, és elismeri a nemzetközi kereskedelem kiemelkedő szerepét. Ezek miatt további figyelmet érdemel az EU tevékenységének elemzése a nemzetközi kereskedelem fejlesztési eszközként való megjelenését illetően.

Ugyan a kereskedelem kérdéskörétől némileg távol esik, viszont az empirikus vizsgálat szempontjából kiemelten fontos a konszenzus megállapítása a segélyezésben prioritást élvező országokat illetően. A konszenzus szerint a legkevésbé fejlett országok a segélyek elsődleges célpontjai a fejlesztési politika szegénységcsökkentésre irányuló célja miatt, valamint a közepes jövedelmü országok közül az alsó közepes jövedelmü országok ${ }^{85}$ támogatását kellene preferálni, különösen, ha ezek az afrikai kontinensen találhatók (EC 2006b, Glennie 2011). Mivel ezek az országok többnyire az ACP-csoportba tartoznak, így mondhatjuk azt is, hogy az ACP-országok támogatása az elsődleges célja a tagállamok és a közösség közös fejlesztési politikai irányvonalaiban.

\footnotetext{
${ }^{84}$ A Gazdasági Partnerségi Megállapodásokat lásd részletesen a dolgozat 5.2.2. fejezetében.

${ }^{85}$ Ezen országcsoportokat a dolgozat 2.1. alfejezetében ismertettük.
} 
A Millenniumi Fejlesztési Célokkal kapcsolatos elvárások az Európai Bizottság egy 2008-as kiadványában (Making trade for development címmel) jelennek meg, és a dokumentum egyértelműen leszögezi: az Európai Unió már 2000 óta a fejlesztési politikájának prioritásaként kezeli a kereskedelmet (EC 2008a). Ugyanez megjelenik a 2008-as GSP-ről szóló tanácsi rendeletben is a (EC 2008d): a közösségi kereskedelempolitika konzisztens a fejlesztési politikával, illetve segíti céljainak megvalósulását. Viszont az említett bizottsági dokumentum szerint ugyan a szabadabb kereskedelem a növekedéshez és fejlödéshez hozzájárulhat, azonban nem lehet kizárólagos eszköznek tekinteni, a fejlödés nem következik be automatikusan. Azaz az EU (f)elismeri, hogy a kereskedelem, a szabad piacra jutás önmagában nem elegendő a gazdasági fejlődéshez (Faber és Orbie 2008), ehhez egyéb kiegészítő politikák (stabil, kiszámítható makrogazdasági politika) szükségesek, valamint fontos, hogy a rászoruló országok fejlesztési stratégiájukban a kereskedelemre is legyenek tekintettel (EC 2008a).

Ezek fényében az új kereskedelmi megállapodás (Cotonou-i Partnerségi Egyezmény), melyet az ACP-országokkal kötött az EU a Loméi Egyezmények lejárta után, kiemelt figyelmet érdemel, hiszen egyrészt a megváltozott nemzetközi környezet és elvárások miatt új alapokra kellett helyezni a kapcsolatot, viszont a kereskedelem fejlödésben betöltött szerepének a továbbiakban is kiemelt figyelmet szentelnek.

\subsection{A Cotonou-i PARTNERSÉgi EgYeZMÉNY}

Miután a Loméi Egyezmények hatálya lejárt (bár 2007-ig ideiglenesen meghosszabbították), annak alapkoncepciója továbbra is megjelenik a 2000-ben az EU és az ACP országok által megkötött Cotonou-i Partnerségi Egyezményben. A következőkben a Cotonou-i Partnerségi Egyezményt, valamint a Gazdasági Partnerségi Megállapodásokat részletezzük.

\subsubsection{A COTONOU-I EGYEZMÉNY FŐBB JELLEMZŐI}

A Cotonou-i Egyezményt 20 évre kötötték, és leginkább abban tér el a Loméi Egyezményektől, hogy a WTO-kötelezettségeknek megfelelően már a kölcsönösségen alapuló kereskedelmi kedvezményeket kell biztosítani. Minden kereskedelmi egyezménynek WTOkonformnak kell lennie, viszont a Loméi Egyezmények nem feleltek meg a WTO 
diszkriminációmentesség, azon belül is a legnagyobb kedvezmény elvének ${ }^{86}$ (Abass 2004, Babarinde és Faber 2004, Cosgrove 1994, Farrell 2005, Hinkle et al 2005, Hurt 2003, Kebonang 2007, Nunn és Price 2004, Santos 1999). A legnagyobb kedvezmény elve kimondja, hogy az országok nem diszkriminálhatnak a kereskedelmi partnereik között, azaz ha valamely országnak biztosítanak valamilyen kedvezményt, akkor azt a többi kereskedelmi partnernek is meg kell adni (WTO 2008), kivéve, ha szabadkereskedelmi egyezményt kötnek. A Loméi Egyezményekkel biztosított kedvezmények viszont csak az egyezményt aláíró ACPországokra vonatkoztak, így a többi (fejlődő) ország az európai piacokon az ACP-országokkal szemben hátrányba került, amit a WTO előtt is sérelmeztek. ${ }^{87}$

E változások mellett azonban olyan elemeket is tartalmaz az egyezmény, amelyek miatt a Cotonou-i Egyezmény teljesen új alapokra helyezi az ACP-országok és az EU közötti kapcsolatokat. Az egyezmény fő célja a gazdasági, társadalmi és kulturális fejlődés elérése az ACP-országokban, valamint - a Millenniumi Fejlesztési Célokkal összhangban - a szegénység csökkentése (Borrmann és Busse 2007, Nurse et al 2008). A fejlesztési együttmüködésben az alábbi új elemek jelentek meg (Degnbol-Martinussen és EngbergPedersen 2005, EC 2000, Karingi et al 2005, Szent-Iványi 2008):

- a partnerség fontos szerepet kap;

- bevezetik a politikai feltételességet: azokat az országokat, melyek megsértik az emberi jogokat, kizárják az együttmüködésböl;

- szélesebb politikai dialógus kialakítása a partnerországok között, amely a fejlesztési együttmüködést, a migrációt, a fegyverkereskedelmet és a biztonságot érinti;

- nem kormányzati szereplők bevonása a fejlesztési együttmüködésbe;

- általános cél a szegénység csökkentése és a fenntartható fejlődés biztosítása mellett a fejlődő országok világgazdasági integrálása;

- a leginkább rászorult országok jogosultak pénzügyi támogatásra, az EU a jobban teljesitőket preferálja (good performers);

- kulcskérdéssé vált az emberi jogok tisztelete, a demokratikus elvek megszilárdítása;

- a Stabex és Sysmin rendszerek eltörlése;

\footnotetext{
${ }^{86}$ A diszkriminációmentesség elvének másik része a nemzeti elbánás elve. E szerint a külföldi partnert, terméket ugyanúgy kell kezelni, mintha nemzeti volna (WTO 2008).

${ }^{87}$ Erre példaként az 1990-es évek elején kirobbant banánvita hozható fel: az ACP-országokból származó banán akadály nélkül juthatott be az EU piacaira, ezzel szemben a latin-amerikai exportőrök komoly korlátozásokkal találták szembe magukat, amit - érthető módon - nehezményeztek. Az ügy végül a WTO vitarendezési fóruma elé került (Abass 2004, Balázs 2002, Kiss 2002), és hosszas egyezkedés után végül csak 2009-ben sikerült egyezségre jutni, erről lásd részletesen Kacsirek (2010) tanulmányát.
} 
- a fejlesztési együttmüködés két pillére továbbra is a kereskedelem és a segély maradt. ${ }^{88}$

Az új egyezmény számos ponton eltér a Loméi Egyezményektől (5.1. táblázat), így az új partnerségi megállapodás - Babarinde és Faber (2004) véleményét osztva, Horváth (2005) kijelentését elvetve - véleményünk szerint tulajdonképpen csak annyiban tekinthető a negyedik Loméi Egyezmény folytatásának, hogy annak lejárta után ez az egyezmény lépett életbe. A Cotonou-i Egyezmény a gazdasági és társadalmi fejlődés helyett sokkal konkrétabb célokat fogalmaz meg (szegénység csökkentése), és „minden olyan regionális és szubregionális integrációs folyamatot támogatni kell, mely a kereskedelem és a magánbefektetések terén elösegíti az ACP-országok integrációját a világgazdaságba" (EC 2000, 8. o.). Emellett továbbra is kiemelt figyelmet szentelnek a fenntartható fejlődésre és a szegénység csökkentésére (Nielson 2000). Mindennek fényében a kereskedelmi kapacitás és lényegében a kereskedelemre való képesség az ACP-országokban még jelentősebb szerephez jutnak, hiszen az európai piacokon számos fejlettebb országgal kell versenyezniük, és már a kedvező piacra lépés adta kedvezőbb árelőnyüket is elveszítették.

5.1. táblázat A Loméi és a Cotonou-i Egyezmények közötti föbb különbségek

\begin{tabular}{|c|c|c|}
\hline Szempont & Loméi Egyezmények & Cotonou-i Partnerségi Egyezmény \\
\hline Cél & gazdasági és társadalmi fejlődés & $\begin{array}{l}\text { országok reintegrációja a } \\
\text { világgazdaságba, szegénység } \\
\text { felszámolása, fenntartható fejlődés, } \\
\text { erős fejlesztési és politikai dimenzió }\end{array}$ \\
\hline $\begin{array}{l}\text { Aláíró ACP-országok } \\
\text { száma }\end{array}$ & 68 & 78 \\
\hline Hatály & $5(10)$ év & 20 év (ötévenkénti felülvizsgálat) \\
\hline Kedvezmények & viszonosság nélküli & kölcsönösségen alapuló \\
\hline $\begin{array}{l}\text { Differenciálás az aláírók } \\
\text { között }\end{array}$ & $\begin{array}{c}\text { nem jellemzó, legfeljebb legkevésbé } \\
\text { fejlett ország }\end{array}$ & $\begin{array}{l}\text { jellemzô, gazdasági partnerségi } \\
\text { megállapodások }\end{array}$ \\
\hline Keretmegállapodás & nem & igen \\
\hline Almegállapodások & nincs & $\begin{array}{l}\text { gazdasági partnerségi egyezmények, } \\
\text { „Fegyverek kivételével mindent” }\end{array}$ \\
\hline $\begin{array}{l}\text { Szabadkereskedelmi } \\
\text { törekvés }\end{array}$ & nincs & van (2020-ig) \\
\hline
\end{tabular}

Forrás: saját szerkesztés

Fontos kiemelnünk, hogy - a Loméi Egyezmények ötéves időszakaitól eltérően - a Cotonou-i Egyezményt húsz éves időtartamra kötötték, és ötévente felülvizsgálják, beleértve az ötéves pénzügyi keretet is (Babarinde és Faber 2004, EC 2000, Moreau 2000). Ezek alapján ez az egyezmény ugyanúgy biztosítja a folytonosságot, a stabilitást, valamint a megváltozott környezethez való alkalmazkodás lehetőségét is, mint a Loméi Egyezmények, ami így az ACP-országok számára gazdasági kiszámíthatóságot biztosít.

\footnotetext{
${ }^{88}$ E két tényezőt vizsgáljuk együttesen az Aid for Trade hatásainak empirikus elemzése során.
} 
További különbség a Loméi Egyezmények és a Cotonou-i Egyezmény között, hogy míg a Loméi Egyezmények egyoldalú kereskedelmi kedvezményekről szóltak, addig a jelenlegi egyezmény már a kölcsönös kedvezmények biztosításán alapszik, és a partnerek közötti szabad kereskedelem (2020-ig történő) megvalósulását irányozza elő, valamint az együttmüködés más, a kereskedelemmel összefüggő területekre (például versenypolitika, szellemi tulajdonjog, fogyasztóvédelem) is kiterjed (Moreau 2000).

Míg a Loméi Egyezményekben nem volt differenciálás az országok között, a Cotonou-i Egyezményben különbséget tesznek a legkevésbé fejlett és a fejlődő országok között, és ezek alapján határozzák meg a lehetséges kereskedelmi kedvezmények körét (5.1. ábra). A legkevésbé fejlett országok számára két lehetőség áll rendelkezésre. Egyrészt még élvezhetik a viszonosság nélküli kedvezményeket, és vámmentesen léphetnek az európai piacokra - ezt a programot az „Everything but Arms” (Fegyverek kivételével mindent) névvel illetik (Babarinde és Faber 2004, Bjornskov és Krivonos 2001), azonban a kezdeményezés alól a fegyvereken túl kivétel a rizs, a cukor és a banán exportja (Gibb 2006).

\section{1. ábra A lehetséges ACP-EU megállapodások köre}

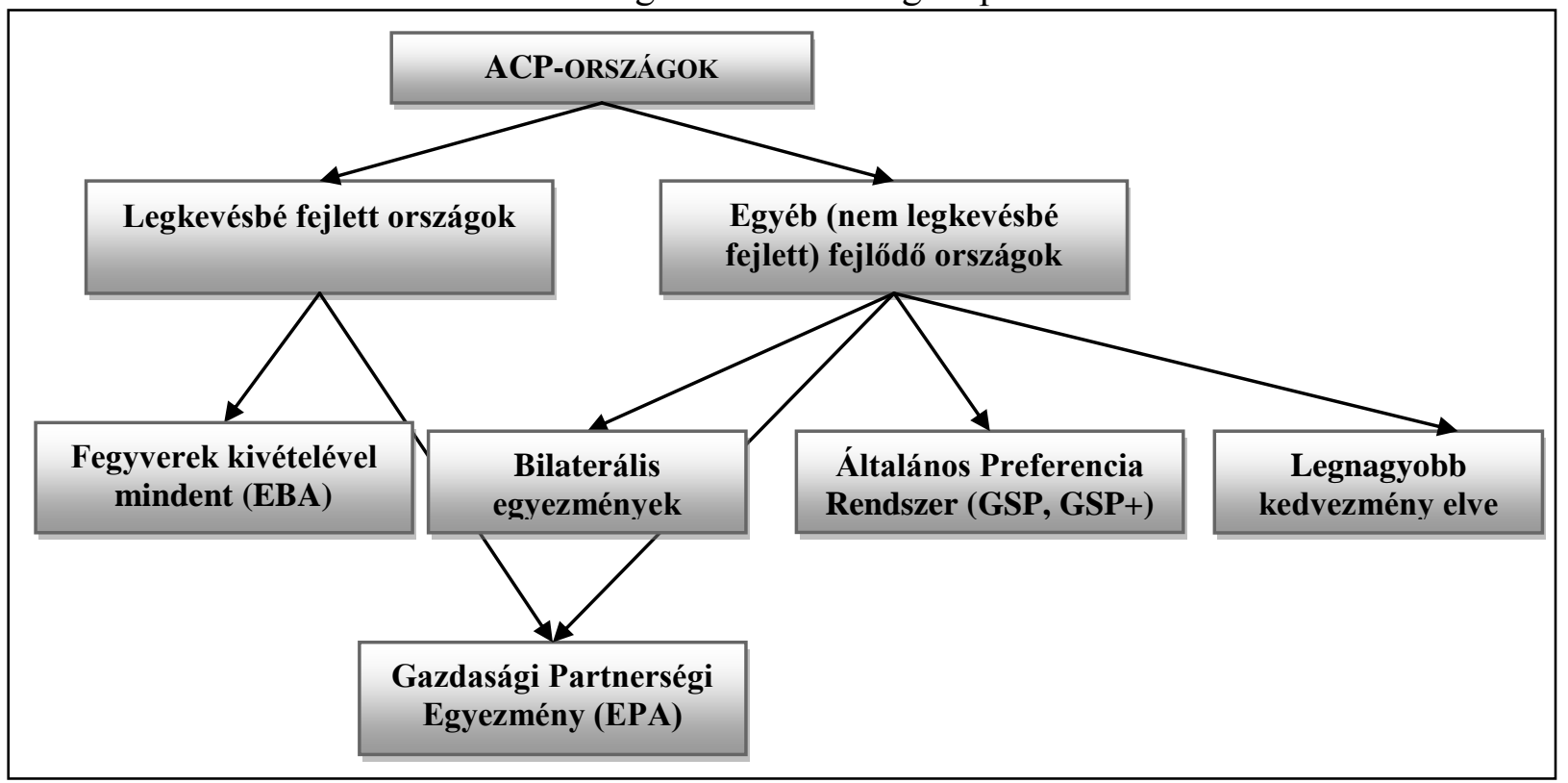

Forrás: saját szerkesztés Babarinde és Faber (2004) és Karingi et al. (2005) alapján

A cukrot illetően Gibb (2006) kiemeli, hogy az EU elsődleges érdeke - továbbra is - a farmerek védelme a liberalizációtól, még akkor is, ha ez a legszegényebb országok kárára valósul meg. Másrészt a legkevésbé fejlett országok dönthetnek úgy is, hogy valamelyik országcsoporttal együtt (a viszonosság elvén alapuló) regionális gazdasági partnerségi megállapodást kötnek az Európai Unióval. 
A fejlődő (értsd: a legkevésbé fejletteken kívüli) országok számára elviekben több lehetőség áll rendelkezésre (5.1. ábra). Köthetnek kölcsönösségen alapuló (regionális) egyezményeket az Európai Unióval, melyeknek a végső célja a kereskedelem liberalizálása (ezek az EPA-k ${ }^{89}$ ). De dönthetnek úgy is, hogy a GSP által biztosított (viszonosság nélküli) kedvezményeket élvezik (Babarinde és Faber 2004, Hurt 2003). Mindemellett lehetőségük van arra, hogy bilaterális szerződést kössenek az EU-val, vagy semmilyen kedvezményt nem vesznek igénybe, és a legnagyobb kedvezmény elve alapján kereskednek egymással (Karingi et al 2005). Az így kialakuló - összesen ötféle típusú - együttmüködés egyértelműen megfelel a Kereskedelmi Világszervezet (kereskedelmi egyezményeket érintő) szabályainak is. Ezek közül a legnagyobb kedvezményen alapuló együttmüködés kialakulásának van a legkisebb valószínüsége, míg a Gazdasági Partnerségi Megállapodások lesznek várhatóan a legkedveltebbek. Összességében a Cotonou-i Egyezmény a politikai és a fejlesztési dimenziót erősítette meg a korábbi Loméi Egyezményekhez képest, és ugyanúgy biztosítja a piacra jutás biztonságát (szerződéses formája miatt), mint ahogyan azt a Loméi Egyezmények is tették (Hinkle et al 2005). Mivel az Aid for Trade elemzése szempontjából kiemelten fontos, így a továbbiakban a Gazdasági Partnerségi Megállapodásokat részletezzük.

\subsubsection{A GaZdasági Partnerségi MegállapodásoK}

A Cotonou-i Egyezmény abban is eltér a Loméi Egyezményektől, hogy csak keretet biztosít a kereskedelmi kedvezmények, fejlesztési területek meghatározásához, viszont már nem magával a teljes országcsoporttal kötöttek keretszerződést, amelynek keretében minden országra ugyanaz a szabály vonatkozott. A Cotonou-i Egyezmény szerint ugyanis terv szerint az országok jelentős fejlettségbeli különbsége, eltérő igényei miatt hat regionális egyezményt, ún. (regionális) Gazdasági Partnerségi Megállapodásokat (EPA) kötnek (legkésőbb 2007 végéig) az ACP-blokkon belüli országcsoportokkal (EC 2000, Farrell 2005, Hinkle et al 2005, Hurt 2003). Ez pedig új kereskedelmi és fejlesztési kapcsolatokra biztosít lehetőséget (Hinkle et al 2005). E regionális megállapodásoknak WTO-konformnak kell lenniük, és a nemzetközi szabályoknak való megfelelést segíti az is, hogy csak egy adott országcsoporttal kötik meg az egyezményt (Farrell 2005). Ezek elsődleges célja - a Cotonoui Egyezmény általános céljának megfelelően -, hogy az ACP-országokat integrálja a globális gazdaságba, és valódi gazdasági fejlődést érjenek el (Curran et al 2008, Slocum-

\footnotetext{
${ }^{89}$ Economic Partnership Agreement
} 
Bradely és Bradely 2010, Ukpe 2010, Vollmer et al 2009). Emellett az EU az EPA-kat fejlesztési politikája részeként kívánja használni (Hinkle és Schiff 2004).

Mivel az EPA-k a kölcsönös kereskedelmi kedvezményeken alapulnak, illetve a 2020ig történő szabad kereskedelem kialakítására épülnek, az ACP-országoknak számos kockázatot jelentenek. Ezek a kockázatok az alábbiak szerint foglalhatóak össze (Boysen és Matthews 2009, Szent-Iványi 2008, Ukpe 2010, Vollmer et al 2009):

- az ACP-országok gazdasági szerkezete nem tud alkalmazkodni időben az új körülményekhez a nem megfelelö kínálatoldali kapacitása miatt;

- a csökkenő vámbevételek a fejlesztési projektek elhalasztásához vezethetnek;

- a regionális integrációknak kereskedelemteremtő és kereskedelem-eltérítő hatásai vannak, így az országok nem ugyanolyan mértékben nyernek a regionális integrációból;

- az európai termékek és cégek által támasztott verseny károsan hathat az ACPországokban lévő vállalatokra;

- az átmeneti egyezmények akadályozhatják a regionális integrációs folyamatokat az afrikai országok között;

- a jelentős EU-s mezőgazdasági támogatások egyenlőtlen versenyt eredményeznek;

- az EU egészségügyi előírásokra hivatkozva akadályozhatja az ACP-országok mezőgazdasági exportját;

- a hat régió többnyire természeti kincsek exportjára szakosodott: gyémánt, olaj, pálmaolaj, amelyek a régiók teljes exportjának több mint 40 százalékát teszik ki, így az egyoldalú kereskedelem káros lehet számukra egy szabad kereskedelmi övezetben;

- az EPA-k olyan szabályokat, területeket is lefednek, melyek egyértelmüen az Európai Közösség érdekeit szolgálják (például szellemi tulajdon védelme, szolgáltatáskereskedelem, beruházások).

E kockázatok ismeretében nem véletlen, hogy az EPA-k lehetséges gazdasági hatásainak vizsgálata még mindig több elemzés tárgyát képezi, viszont az eredmények vegyesek a kereskedelemteremtés és -eltérítés hatásai miatt (ODI 2006). Hinkle és Schiff (2004) hangsúlyozzák e kezdeményezés pozitív oldalát, és úgy látják, hogy megfelelő alapot jelent az ACP-országok világgazdasági reintegrációjának elősegítésére. Anania (2010) elemzése szerint az ACP-országok egyértelműen nyernek az EPA-k által a 
banánkereskedelem területén. Azonban Borrmann és szerzőtársai (2007) empirikus úton igazolt eredményei felhívják arra is a figyelmet, hogy az aláíró országoknak jelentős többletköltséggel kell szembesülniük: ugyan a kereskedelem volumene megnő, viszont a szabad kereskedelemmel járó vámcsökkentések (-eltörlések) miatt jelentős hatással van a költségvetésre is, így ezen országoknak az alkalmazkodáshoz strukturális és pénzügyi igényei lehetnek az egyezmények végrehajtása során. A szerzők viszont azt is kiemelik, hogy az EPA-k - a regionális csoportokkal történő tárgyalások miatt - hozzájárulhatnak ahhoz, hogy az Afrikában oly jellemző, egymást átfedő (egyszerre több integráció tagjai is az országok), kaotikusnak (és egyáltalán nem sikeresnek) mondható regionális integrációk átláthatóbbak legyenek. ${ }^{90}$

Ezek mellett számos negatív eredménnyel záruló tanulmány is található. Karingi és szerzőtársai (2005) az EPA-k jóléti hatásait elemezték az afrikai országok vonatkozásában. Eredményeik szerint az EU nyer a legtöbbet a megállapodásokból, és a megnövekedett kereskedelem a kereskedelemteremtés és a világ más részei felől történő kereskedelemeltérítés következménye. A szerzők továbbá hangsúlyozzák, hogy az afrikai országok nagy valószínüséggel a kormányzati bevételek csökkenésével szembesülnek majd az alacsonyabb vámok miatt, ami pedig magasabb alkalmazkodási költséggel jár.

Vollmer és szerzőtársai (2009) - Karingi et al (2005) munkájához hasonlóan - az ideiglenes egyezmények jóléti hatásait elemezték kilenc fekete-afrikai országban. Eredményeik szerint négy országban a vámcsökkentés pozitív hatással jár, míg a többi országban nem tapasztalható pozitív jóléti hatás. Ugyanakkor a szerzők amellett érvelnek, hogy a vámcsökkentés során elszenvedett veszteség nem jelenti feltétlenül azt, hogy az EPA-k negatívan hatnak az afrikai országokra, hiszen még így is többet nyernek ezek az országok, mint az egyszerű GSP által biztosított kedvezményekkel. Ahhoz azonban, hogy ez valóban így legyen, az afrikai országok számára hosszabb átmeneti időt és alacsonyabb piacnyitást kellene elöírni. Ez egyértelmüen elfogadható annak ismeretében, hogy az EPA-k nem csak a kereskedelem szabályozására térnek ki. A szerzők is kiemelik azt, hogy az EU lesz az egész ügylet nyertese, viszont szerintük ezt a pluszhasznot a fejlesztési együttműködés bővítésére kellene fordítani.

Busse és Grossman (2007) az EPA-k fiskális és kereskedelmi hatásait nyugat-afrikai országokban vizsgálták. Empirikus vizsgálatuk alapján a szabad kereskedelmi egyezménnyel járó vámcsökkenés komoly gazdasági problémákat okoz az afrikai országok számára, így a

\footnotetext{
${ }^{90}$ Az afrikai integrációkról lásd például Shams (2005) vagy az UNCTAD (2009) tanulmányát.
} 
szerzők hasonlóakat javasolnak, mint Vollmer és szerzőtársai (2009): kiegészítő reformokra van szükség, mielött az EPA-k életbe lépnek. Továbbá, Borrman és Busse (2007) hangsúlyozzák, hogy azok az országok tudnak hasznot húzni az EPA-k gazdasági változásaiból, amelyek magas minőségü intézményi háttérrel rendelkeznek, így a szerzők végkövetkeztetése szerint az afrikai országok lehetnek a szabad kereskedelmi egyezmények legnagyobb vesztesi. Boysen és Matthews (2009) a vizsgálataikat Ugandára szükítették le. A szerzők arra jutottak, hogy a veszteség nagymértékben függ attól is, hogy mennyire érzékeny termékeket vonnak be a tárgyalásokba, de a szerzők egyértelműen azt állítják, hogy az ország legszegényebb rétege lesz az új gazdasági partnerségi megállapodások legfőbb vesztese. Fontagné és szerzőtársai (2008) szerint az ACP-országok vesztesége óriási lesz a vámcsökkentések miatt, és sok múlik azon, hogy az ACP-blokk milyen kiegészítő reformokat tud megvalósítani, és hogy ezek az országok hogyan tudják megváltoztatni a fiskális bázisukat (lényegében a vámfüggőségüket csökkenteni).

Összességében a félelmek és az EPA-k tartalma alapján meghatározható kockázatok miatt nem meglepő az, hogy a fejlődő országok többletforrást igényelnek az új körülményekhez történő alkalmazkodáshoz, beleértve az intézményi háttér javítását is. Ezt a (többlet)finanszírozási igényt az Aid for Trade hidalhatja át, ugyanis az ACP-országok kifejezetten kérték azt, hogy az Aid for Trade kezdeményezést kapcsolják e gazdasági megállapodásokhoz annak érdekében, hogy segítsék azok végrehajtását (Hinkle et al 2005, Meyn 2008). Ahogy a 2005-ös politikai koherenciát taglaló bizottsági anyag is hangsúlyozza (EC 2005b, 8. o.): „Az EPA-k végrehajtását fejlesztési együttmüködés támogatja, különösen a kínálatoldali kapacitás és versenyképesség megerösitésén keresztül." Ezek a tényezők pedig egyértelműen arra utalnak, hogy a kereskedelmi oldal továbbra is fontos szerepet játszik az EU fejlesztési politikájában, és már azt is előrevetítik, hogy az EU kiemelten próbálja kezelni az Aid for Trade adta lehetőségeket is. Mindez pedig a dolgozat következő empirikus vizsgálatának szempontjából kiemelten lényeges.

Az EPA-tárgyalások viszont nem mentek olyan könnyedén, mint ahogy azt talán az EU várta. Ennek oka lehet, hogy a Cotonou-i Egyezmény csak azt fekteti le, hogy 2007 végéig meg kellene kötni az egyezményeket, viszont a megvalósítás módjára már nem tér ki (Karingi et al 2005), de szerepet játszhat az is, hogy a szimpla árukereskedelmen túl már több területet lefednek. Szent-Iványi (2008) és Ukpe (2010) szerint a tárgyalások megakadásának oka inkább a bizalom hiánya valamint a növekvő szkepticizmus az Európai Unióval szemben: az ACP országok nem bíznak már az EU-ban. A tárgyalások 2007-es lezárása mindössze egy 
régióban valósult meg: a karibi országokkal sikerült az átfogó egyezmény tárgyalását befejezni (lefedve az áruk, szolgáltatások, szellemi tulajdon, beruházások területét) (Nurse et al 2008, Vollmer et al 2009). A többi régióval mindössze átmeneti egyezményeket sikerült kötni, amelyek átlagosan 80-95 százalékos liberalizációt írtak elő a következő 15-20 évre (5.2. táblázat), miközben az EU az ACP-országok számára szabad piacra lépést biztosít (SzentIványi 2008).

5.2. táblázat A piacnyitás mértéke és határidő az ACP-régiókban

\begin{tabular}{lccc}
\hline \multicolumn{1}{c}{ Régió } & Egyezmény típusa & $\begin{array}{c}\text { Piacnyitás } \\
\text { mértéke (\%) }\end{array}$ & $\begin{array}{c}\text { Határidö (éven } \\
\text { belül) }\end{array}$ \\
\hline Karibi & végső & 61 & 10 \\
\hline Kelet-afrikai & átmeneti & 82.7 & 15 \\
Közösség & EBA & 64 & 2 \\
\hline Kelet- és Dél-Afrika & átmeneti & 80 & 25 \\
\hline Dél-Afrika & EBA & változik a tagok \\
között: $80-97$ & 86 \\
\hline Csendes-óceáni & átmeneti & 88 (PNG) & 15 \\
térség: Pápua Új- & EBA (Angola) & 80 (Fiji) \\
Guinea, Fiji & átmeneti & EBA & 80 \\
\hline Közép-Afrika & bilaterális (Kamerun) & & 15 \\
\hline Nyugat-Afrika & EBA & 70 (Elefántcs.) \\
\hline
\end{tabular}

Forrás: Vollmer et al (2009) alapján saját szerkesztés

Ezek alapján a fejlődő országok által kért kiegészítő forrásoknak kiemelkedő szerepük lehet abban, hogy a Gazdasági Partnerségi Megállapodásokat nemhogy implementálni, de egyáltalán lezárni tudják. A bemutatott empirikus tanulmányok azzal a végkövetkeztetéssel zártak, hogy kiegészítő reformokra van szükség, az intézményi hátteret javítani kell annak érdekében, hogy ezek a fejlődő országok is élvezni tudják a szabad kereskedelem adta lehetőségeket. Ezek miatt az Aid for Trade-re úgy tekintenek, mint az az eszköz, amely lehetővé teszi számukra, hogy az új körülményekhez alkalmazkodjanak. Ezzel pedig a fejezet végén szereplő empirikus vizsgálatunk alapja egyértelmüen adott. Annak érdekében, hogy az EU-s Aid for Trade támogatások hatásvizsgálata minél pontosabb legyen, a következőkben megvizsgáljuk, hogy az Aid for Trade hogyan illeszkedik a közösségi fejlesztési politikába.

\subsection{AZ AID FOR TRADE AZ EURÓPAI UNIÓBAN}

Bár az Európai Unió a világ legnagyobb donorszervezetének számít, már az Aid for Trade általános bemutatása során (3.3.2. fejezet) is láthattuk, hogy a (hazai és nemzetközi) 
kutatásokban nem található arra vonatkozó vizsgálat, hogy az Aid for Trade mennyiben illeszkedik az EU tevékenységébe, és az EU egyáltalán milyen szerepet vállal annak megvalósításában. Mindez annak ellenére így van, hogy a Gazdasági Partnerségi Megállapodások végrehajtásának egyik eszközeként tekintenek az AfT-re. Holott - ahogy azt már láthattuk a dolgozat 3.3.3. fejezetében - az Aid for Trade lehetséges hatásait összességében pozitívan ítélik meg. Ezek alapján különösen indokolt, hogy részletesebben kitérjünk az Aid for Trade megjelenésére az Európai Unióban, annak jellemzőire, illetve bemutassuk, hogy az Aid for Trade mennyiben járulhat hozzá a fejlesztési politika hatékonyságának növeléséhez. Ehhez elsősorban az ACP-országokat, illetve a Loméi Egyezményeket hívjuk segítségül.

\subsubsection{AZ AID FOR TrADE STRATÉGIA}

Az Aid for Trade egyre nagyobb szerepet kap az Unióban is, és egyre több értékelés, jelentés születik a programról és annak fejlesztéspolitikai integrálási lehetőségéről. Azt, hogy az Aid for Trade mennyire előtérbe került az Európai Unióban is, jól mutatja, hogy a Bizottság a tagországok egyetértésével 2007-ben elfogadta az Unió AfT-stratégiáját, mely öt pilléren alapszik (EC 2007, EC 2009b):

- Mennyiségi célkitüzések. Mind a hagyományos, mind pedig a tágabb értelemben ${ }^{91}$ vett Aid for Trade pénzeket növelni kellene úgy, hogy arányos legyen a fejlesztési támogatások növekedésével. Emellett célul tüzték ki a hagyományos támogatások kétmilliárd euróra történő növelését 2010-re.

- Minőségi és szegénység-megelözési célkitüzések, ahol a legfontosabb, hogy a segélyek nyújtása feleljen meg a segélyek hatékony felhasználására vonatkozó Párizsi Deklarációnak. Az EU ezzel is próbálja a fejlesztési politikájának célját (szegénységcsökkentés) megvalósítani.

- Európai Uniós kapacitások bövitése. Azaz meg kell találni a megfelelő eszközöket, lehetőségeket arra, hogy a rendelkezésre álló támogatások bővüljenek. Ennek egyik legfontosabb módja, hogy az elérhető kapacitásokról információt cseréljenek, valamint közös fellépés valósuljon meg ott, ahol lehet - azaz az egyes tagállamok próbálják

\footnotetext{
${ }^{91}$ Az Európai Unióban az Aid for Trade hat területét két csoportra osztják: a szükebb AfT mindössze két területet foglal magában (kereskedelempolitika és kereskedelemfejlesztés), és ez a hagyományos (klasszikus) kereskedelemmel összefüggő támogatási célok (trade-related assistance). A tágabb értelemben vett AfT (wider Aid for Trade) pedig mind a hat területet tartalmazza (EC 2009b).
} 
összehangolni, harmonizálni tevékenységüket (ahogyan ezt a Lisszaboni Szerződés idézett cikkelyében is láthattuk).

- ACP-országok elötérbe helyezése. Mivel az EU a legtöbb preferenciát ezeknek az országoknak nyújtja, így egyértelmü, hogy a velük kialakított kapcsolat mélyítése és hatékonyabbá tétele érdekében az Aid for Trade adta lehetőségeket is ki kell használni. Annak érdekében, hogy egy ország részesülhessen a támogatásból, a kereskedelmet a nemzeti fejlesztési programokban szerepeltetni kell. Továbbá az EU célul tüzte ki, hogy a megnövekedett fejlesztési támogatások körülbelül 50\%-ának az ACP-országok igényeit kell szolgálnia.

- Hatékony monitoring és ellenörzési rendszerek. Ennek érdekében jelentéseket kell készíteni az EU-n belül, valamint jelentéseket és adatokat kell továbbítani a Kereskedelmi Világszervezet felé. ${ }^{92}$

Az Aid for Trade kapcsán emlegetett vitás pont az, hogy a meglévő eszközök átcsoportosításáról van-e szó, vagy pedig új források bevonását igényli-e (Udvari 2009b), azonban úgy tünik, hogy elsősorban átcsoportosításról beszélhetünk. Az EU-ban is hasonló tendencia figyelhető meg, hiszen az Aid for Trade finanszírozása többféle forrásból történik. Mivel a programra jutó segélyek, támogatások az EU fejlesztési támogatásainak része (EC 2009b), így a finanszírozása is hasonló eszközökkel történik, és nincs külön Aid for Trade-alap. Az Európai Unióban az AfT-források egyik része a közös költségvetéstől független ${ }^{93}$ Európai Fejlesztési Alapból származik, viszont az innen származó támogatások az ACP-országoknak nyújtott támogatásokat tartalmazzák. Az Európai Fejlesztési Alap a 2007-13 közötti költségvetési periódusban 22,6 milliárd eurót biztosít az ACP-országok számára (EC 2009b).

Az AfT finanszírozásának másik EU-s forrása a közös költségvetés: a LatinAmerikában és Ázsiában található országok számára a Fejlesztési Együttmüködési Eszközön (Development Cooperation Instrument) keresztül juttatnak támogatást, melynek összege a jelenlegi költségvetési időszakban 16,8 milliárd euró (EC 2009b). A szomszédságpolitikán keresztül a szomszédos országoknak és Oroszországnak 11,18 milliárd eurót szánnak, az elő́csatlakozási alapokból pedig a Balkán országainak és Törökországnak közel 11,5 milliárd

\footnotetext{
${ }^{92}$ Az Európai Bizottság évente kiad egy jelentést az Aid for Trade tevékenységéről, a legutolsó ilyen jellegü dokumentuma a 2010-ben megjelent Aid for Trade Monitoring Report (EC 2010).

${ }^{93}$ Kísérletek ugyan történtek az Európai Fejlesztési Alap beépítésére, ez még nem valósult meg, és úgy tünik, hogy ez a következő programozási időszakban (2014-2020) is így lesz.
} 
euró áll rendelkezésre. Viszont ezek az összegek a teljes fejlesztési támogatást takarják, így nem lehet pontosan tudni, hogy az Aid for Trade valójában mekkora összeget jelent.

Az Aid for Trade stratégia és a pénzügyi eszközök megléte már mutatják, hogy az EU elkötelezte magát a program mellett, sőt kifejezett célja is van ezzel: a Gazdasági Partnerségi Megállapodások implementálásában nyújthat segítséget, ahogyan erről a dolgozat korábbi fejezetében már szóltunk. Az Európai Unió által finanszírozott Aid for Trade-projektek száma folyamatosan emelkedik: 2008-ban összesen 12.377 projektet lehetett az Aid for Trade kezdeményezéshez kötni, és több mint 130 országban jelentek meg - a legtöbb programot Indiában (328), Vietnámban (311), illetve Kínában (295) valósították meg, amelyek önmagukban több projektet jelentenek, mint az egész Fekete-Afrikában megvalósított projektek száma (206) (EC 2010). Ez pedig felveti a kérdést, hogy menyire lehet még ACPspecifikusságról beszélni. Továbbá, az Aid for Trade egy teljesen különálló program, vagy valamilyen mértékben köthető az EU korábbi fejlesztési tevékenységéhez? Így meg kell vizsgálni, hogy az Aid for Trade a maga célkitüzéseivel hogyan illeszthető be az EU fejlesztési politikájába és mennyiben tudja javítani annak hatékonyságát.

\subsubsection{AZ AID FOR TRADE ILLESZKEDÉSE AZ EU FEJLESZTÉSI POLITIKÁJÁBA}

Annak megállapítása érdekében, hogy ez a kezdeményezés milyen mértékben illeszkedik az Európai Unió fejlesztési tevékenységébe, korábbi tevékenységének eredményeit vizsgáljuk meg. Ha elemezzük, hogy korábban milyen hibák, illetve hiányosságok merültek fel, valamint ha ezeket összevetjük az Aid for Trade területeivel, következtethetünk arra, hogy az új nemzetközi program mennyiben járulhat hozzá az EU fejlesztési tevékenységéhez. Mivel az Aid for Trade is a kereskedelem szerepét hangsúlyozza, így egyértelmü, hogy a kereskedelmi vállalkozások - elsősorban a Loméi Egyezmények - eredményességével vessük össze.

Az Európai Unió korábbi tevékenységének lehetséges hátráltató tényezőit (lásd korábban a 4.20. táblázatot) összevetve az Aid for Trade területeivel (lásd a 3.3.2. fejezetben), egyértelmüen kitünik, hogy az Aid for Trade alkalmas lehet az alacsony hatékonyságot okozó tényezők felszámolására, illetve fejlesztésére. A kedvezőtlen folyamatok alakulásában szerepet játszó tényezők közül csak a belső tényezőket emeljük ki, hiszen az Aid for Trade kizárólag az országon belüli folyamatokra képes hatni, a világgazdasági eseményeket és annak hatásait nem, vagy csak nagyon csekély mértékben, közvetett módon tudja befolyásolni. Mindezek alapján az alacsony hatékonyságot okozó tényezők közül a korrupció 
kivételével az összes többi tényező fejlesztésére kérhető támogatás az Aid for Trade alapján (5.2. ábra).

5.2. ábra Az alacsony hatékonyság okai és az Aid for Trade

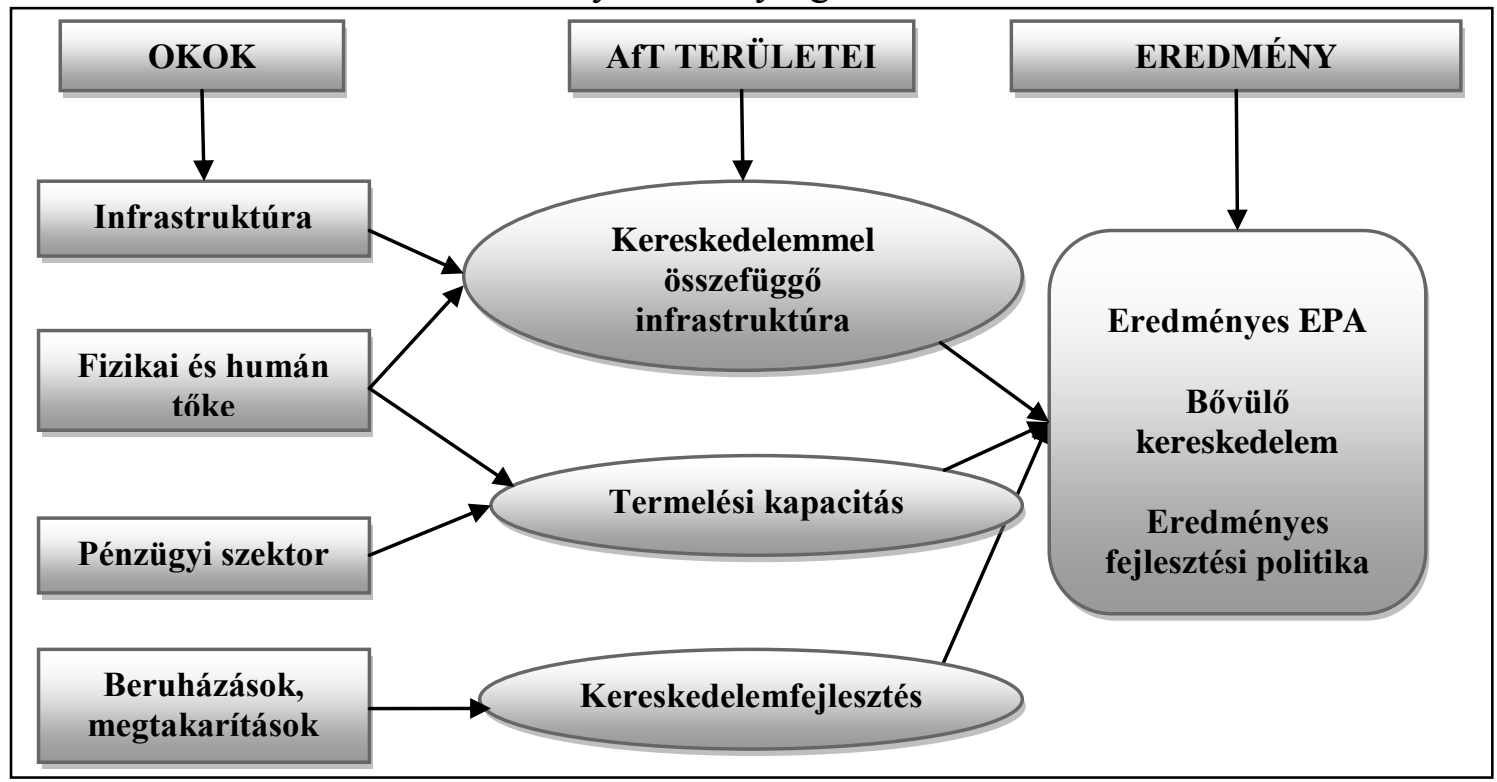

Forrás: saját szerkesztés Udvari (2010c), 35. o. alapján

A fogadó országok alacsony színvonalú infrastruktúráján, valamint az alacsony szintű humán tőkén a fogadó ország javíthat a kereskedelemmel összefüggő infrastruktúra kereteiből érkező támogatásokkal. A pénzügyi szektor fejletlenségén pedig a termelési kapacitás kiépitésének témakörből érkező támogatások nyújthatnak segítséget, továbbá a beruházások alacsony szintjén, a külső források megszerzésében jelentős szerepet játszhat a kereskedelemfejlesztés címén érkező támogatások. Az eredményes Aid for Trade-felhasználás pedig hatékony és kereskedelembővítő Gazdasági Partnerségi Megállapodásokat jelent majd, valamint ugyancsak eredményes európai fejlesztési politikát.

Mindez azt jelenti, hogy az Aid for Trade teljes mértékig illeszkedik az Európai Unió fejlesztési tevékenységébe. Az AfT adott területeire érkező támogatások képesek lehetnek a korábbi eredménytelenség okainak kiküszöbölésére, ezzel pedig hozzájárulhatnak a jelenlegi, a Cotonou-i Egyezmény eredményességéhez. Következésképpen a korábbi és jelenlegi tevékenységek között megtaláltuk a kapcsolódási pontokat. Az EU fejlesztéspolitikai eszközrendszerét illetően pedig az Aid for Trade már nem különíthető el élesen a kereskedelempolitikai és pénzügyi eszközöktől: az eszközöket és a célokat tekintve az AfT az EU-s fejlesztési politika pénzügyi és a kereskedelempolitikai eszközeinek összekapcsolását jelenti (lásd korábban a 4.1. táblázatot). Az új nemzetközi programon keresztül ugyanis azért lehet forrásokhoz jutni (pénzügyi eszköz), hogy a támogatott országok 
a kereskedelmi kapacitásokat növelni tudják - annak érdekében, hogy a nemzetközi kereskedelemben minél hatékonyabban tudjanak részt venni, és be tudjanak kapcsolódni a nemzetközi munkamegosztásba (kereskedelempolitikai eszköz). Ezzel pedig valóban hozzájárulhat a Cotonou-i Egyezmény kötelezettségvállalásainak teljesítéséhez.

Érdekes továbbá az is, hogy az Európai Unió - saját stratégiájával összhangban és az ACP-országok kiemelt szerepének megfelelően - az afrikai régió számára juttatja a legtöbb támogatást arányaiban nézve (Udvari 2010c), holott a világ teljes támogatásait illetően nem ez volt a tendencia (Udvari 2009b). Ennek fényében érdemes megvizsgálni azt, hogy az Aid for Trade a Loméi Egyezmények már-már tragikus kereskedelmi hatásait mennyiben tudja ellensúlyozni, és az ACP-országok esetében hozzájárulhat-e az EU-val folytatott kereskedelmük bővüléséhez. Azaz vizsgálatunk során a segélyezés már összekapcsolódik a nemzetközi kereskedelem kérdéseivel. Ez azért is érdekes kérdés, mert a donor ország - jelen esetben az Európai Unió - elvárhatja azt, hogy az ő termékeit vásárolja meg, ezzel a donor exportja és a fogadó ország importja növekszik (Wagner 2003).

Azonban a közösségi fejlesztési politika alakulását és az ACP-országokkal kialakított kapcsolatot nem kizárólag a külső tényezők változása, a nemzetközi közösség nyomása, új irányvonalak megjelenése határozta meg, hanem az Európai Unió 2004-es és 2007-es bővítése is jelentős hatással bírt. Mivel a következőkben az Európai Unió tevékenységét a 2000-es évek közepe óta elemezzük, így szükséges arra is kitérni, hogy az új tagországok megjelenése mennyiben befolyásolja a közösségi fejlesztési politikát. Hangsúlyozzuk, hogy csak a legfontosabb (általánosan jellemző) elemekre térünk ki, melyek az európai fejlesztési politikára hatással voltak, az egyes országok fejlesztéspolitikai sajátosságait, fejlődését nem részletezzük. ${ }^{94}$ Ezek az ismeretek a későbbi empirikus vizsgálat jobb megértéséhez és annak módszertani indoklásához járulnak hozzá.

\subsection{AZ ÚJ TAGÁLLAMOK SZEREPE A KÖZÖSSÉGI FEJLESZTÉSI POLITIKÁBAN}

Az évezred utáni bővítések sajátossága, hogy olyan országok csatlakoztak az Európai Unióhoz, melyek korábban jelentős segélyfelvevők (recipiensek) voltak, és csatlakozásukkal vállalták, hogy segélynyújtóvá (donor) válnak (Lightfoot 2008, Migliorisi et al 2003). A tagjelölt országoknak elöírták, hogy olyan nemzetközi fejlesztési politikát alakítsanak ki, mely illeszkedik az ENSZ, az EU és az OECD Fejlesztési Bizottságának elveihez (Jakab

\footnotetext{
${ }^{94}$ A tíz új tagországra vonatkozóan lásd például Migliorisi és szerzőtársai (2003) tanulmányát, illetve a visegrádi országokról például Dauderstädt (2002) vagy Szent-Iványi (2009b) munkáját.
} 
2005), viszont a fejlesztési együttműködés nem képezte a csatlakozási tárgyalások tárgyát (Granell 2005). Következésképpen a csatlakozó országoknak a közösségi joganyag más részeit is el kellett fogadniuk derogáció lehetősége nélkül (Dauderstädt 2002, Lightfoot 2008, 2010, Morgera és Durán 2004): a Cotonou-i Egyezményt, a teljes ACP-kapcsolatrendszert, az európai fejlesztéspolitikai konszenzust, a 3C (3K) elvet, a 10. Európai Fejlesztési Alap kötelezettségvállalásait ${ }^{95}$, a Monterrey konferencián elfogadott és 2005-ben az Európai Tanács által megerősített elveket a fejlesztési források emeléséröl ${ }^{96}$, a Mediterrán partnerséget, az EBA-kezdeményezést, és még lehetne sorolni.

Az ezekhez való alkalmazkodás azonban nem egyszerü. A korábbi befolyásoltság (a szovjet blokk katonai és politikai érdekei) és a kevésbé önálló politika miatt ezen országok fejlesztési politikájának kialakítása és fenntartása kihívásokkal teli. A tíz új tagországnak a közösségitől eltérő fejlesztéspolitikai felfogását jelzi, hogy a közösségi fejlesztéspolitikai célt (azaz a szegénység csökkentését) csak néhány ország tette egyértelmüen magáévá, akárcsak a legkevésbé fejlett, illetve fekete-afrikai államok támogatását (Lightfoot 2010, Migliorisi et al 2003). Elvileg a Lisszaboni Szerződés már mind a 27 tagország egyetértését kell tükröznie a szegénységcsökkentést illetően, azonban a legkevésbé fejlett országok részaránya az európai fejlesztési támogatásokban csökkent (Lightfoot 2010).

Ami a kötelezettségvállalásokat illeti, az új tagállamok is hozzájárulnak az Európai Fejlesztési Alap (EDF) költségvetéséhez, amely - ahogy arra már korábban utaltunk elsősorban az ACP-országoknak nyújt támogatást, viszont összességében az új tagországok nem biztosítanak olyan mértékü támogatást, amely jelentős mértékben megnövelné az EDFből rendelkezésre álló források nagyságát (Lightfoot 2008). Az EU-ból a fejlődő országokba irányuló támogatások mindössze 0,4 százaléka származik az új tagországokból (Granell 2005). Az OECD adatai alapján 2010-ben a közép-kelet-európai országok GNI-arányos segélyei 2010-ben 0,08 és 0,13 százalék között mozgott, és 2009-hez képest nincs jelentős változás (OECD 2010), de a cél a 0,36 százalékos arány elérése 2015-ig. Ezek arra utalnak, hogy bár a tíz új tagország donortevékenységbe kezd, ez nem olyan jelentős mértékü, hogy érdemben hozzájáruljon a közösségi és a régi 15 ország segélyezési tevékenységéhez - legalábbis a pénzügyi forrásokat tekintve. Mindez pedig azt mutatja, hogy az EU-27 segélyezési tevékenységét - nem meglepő módon - az EU-15 segélyezési

\footnotetext{
${ }^{95}$ Mivel a 9. EDF-ről még a csatlakozásuk előtt megállapodtak, nem várták el, hogy annak költségvetéséhez is hozzájáruljanak (Mogliorisi et al 2003).

${ }^{96}$ Lásd erről a pontos számadatokat a dolgozat 4.1. fejezetében.
} 
tevékenysége határozza meg. Ez pedig az Aid for Trade empirikus vizsgálatához fontos információ.

Az Aid for Trade elemzése kapcsán fontos a segélyezés regionális fókuszának vizsgálata is. Az új tagországok nem rendelkeztek gyarmatokkal, így a korábbi politikai kapcsolat hiányában nagyobbrészt a szomszédos országok - elsősorban a volt jugoszláv államok, FÁK-országok, Balkán-országok - fejlesztésére nyújtják a támogatást (5.3. táblázat), és az egyéb (akár afrikai) fejlődő országokba sokkal ritkábban juttatják el (Boros 2005, Dauderstädt 2002, Granell 2005, Kiss 2007a, Lightfoot 2008, Migliorisi et al 2003, Morgera és Durán 2004, Szent-Iványi 2009a, 2009b), holott ezek a területek az európai prioritások között szerepelnek. Az új tagországok célja ezekkel a támogatásokkal a (szomszédos) régió stabilitásának fenntartása és a konfliktus kialakulásának visszaszorítása, nem pedig a globális szegénység és a törékeny államok által támasztott biztonsági kihívások kezelése (Lightfoot 2008, Szent-Iványi 2009a, 2009b). Azaz az új EU-tagországok esetében a segélyek allokációját nem az egy före jutó GDP, nem annak növekedése, illetve nem a háttérintézmények minősége határozza meg (Szent-Iványi 2009a). Mindez pedig azt jelenti, hogy az ACP-országok segélyezése elsősorban az EU-15-től függ, nem pedig az új tagállamok támogatásától.

5.3. táblázat Az új tagországok segélyeinek regionális megoszlása

\begin{tabular}{|c|c|c|c|c|c|c|c|c|c|}
\hline & $\stackrel{\mathscr{Z}}{己}$ & 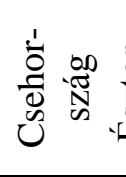 & 畩 & 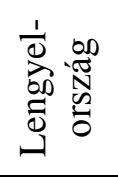 & 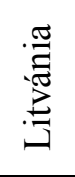 & 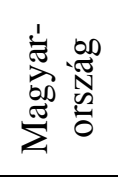 & 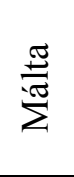 & 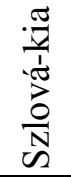 & 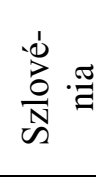 \\
\hline $\begin{array}{l}\text { Moldova, Ukrajna, } \\
\text { Fehéroroszország }\end{array}$ & 2 & 1 & 1 & 1 & 1 & 1 & & & \\
\hline Balkán & 2 & 1 & 1 & 1 & 2 & 1 & & 1 & 1 \\
\hline Közép-Ázsia & & 2 & 2 & 2 & & & & 1 & \\
\hline Közel-Kelet & 1 & 3 & & & & & & & \\
\hline Afrika & & 3 & & & & & 1 & 3 & \\
\hline Délkelet-Ázsia & & 3 & & 3 & & 3 & & 3 & \\
\hline Latin-America & & 3 & & & & & 3 & 3 & \\
\hline
\end{tabular}

Annak ellenére, hogy minden EU-s dokumentum az ACP-országokat teszi meg a legnagyobb kedvezményezettnek, az új tagországokat nem kötelezik arra, hogy ezen államoknak folyósítsanak minél több támogatást (Lightfoot 2010). A kevesebb afrikai, karibi kapcsolatok és a jelentősebb szomszédsági tevékenységek következtében nem meglepő, hogy az EU-ban is nagyobb figyelem - és költségvetési támogatás - irányul a szomszédság 
kérdésére, valamint a csatlakozás előtt álló országok támogatására (Lightfoot 2008). Ezt akár az új tagországok sikerének is tekinthetjük, viszont így az EU fókusza más térségek felé tolódik, amely az ACP-országok háttérbe szorulásával is együttjárhat.

Az Aid for Trade empirikus vizsgálata szempontjából mindebből következően az alábbi tanulságok említhetők meg az új tagországok megjelenése kapcsán: ugyan bővült a rendelkezésre álló fejlesztési keret, azonban ezt nem lehet szignifikáns mértékűnek tekinteni. Ennek ellenére az új tagországoknak jelentős szerepe van az európai fejlesztési politika területi fókuszának eltolódásában: az EU közeli szomszédságát adó államok az ACP-országok versenytársai lettek. Viszont egyelöre nem lehet azt mondani, hogy az ACP-országok teljesen háttérbe szorultak volna, hiszen még a legtöbb EU-s dokumentum őket tekinti az elsődleges kedvezményezettnek, illetve velük írták alá a Cotonou-i Egyezményt és velük kötik meg a gazdasági partnerségi megállapodásokat.

Az elmúlt fejezetekben bemutatott elméleti fejtegetések alapján fogalmaztuk meg a dolgozat bevezetőjében már említett 3. és 4. hipotézist, melyeket a könnyebb áttekinthetőség érdekében újra megismételünk, és a dolgozat következő részében az empirikus vizsgálat ezek tesztelésére irányul:

- 3. hipotézis: Az Aid for Trade céljai és beavatkozási területei alapján illeszkedik az Európai Unió fejlesztési politikájába, és az egyéb fejlesztéspolitikai eszközök hatékonyságának javításához hozzájárul.

- 4. hipotézis: Az ACP-országok több Aid for Trade-támogatásban részesülnek, mint a csoporton kívüli fejlődő országok, és a támogatások kereskedelembővítő hatása az ACP-országok körében nagyobb, mint az ACP-csoporton kívüli országokban.

Az 1. és 2., illetve a 3. és a 4. hipotézis együttese alapján fogalmaztuk meg az utolsó, 5. hipotézist, melyre - lényegében - az első négy hipotézis adta válaszok függvényében lehet válaszolni. Emlékeztetőül:

- 5. hipotézis: Az EU fejlesztési céllal használt kereskedelempolitikai eszközei hozzájárulnak az ACP-országok gazdasági fejlődéséhez.

\subsection{AZ AID FOR TRADE LEHETSÉGES hatÁSAI AZ EU-VAL FOLYTATOTT KERESKEDELEMRE}

A dolgozat korábbi, 4.3. fejezetében ismertetett empirikus elemzés alapján a Loméi Egyezmények az aláíró országok számára nem tudtak kiemelkedő lehetőségeket biztosítani, és 
a szabad piacra lépés nem hozott lényeges gazdasági fejlődést az aláíró országok többségében. A klaszterelemzés rámutatott arra is, hogy az ACP-országok nagyobb része a 2000-es évek elején még mindig relatíve kisebb arányú kereskedelmet folytatott az Európai Unióval, mint más, nem a legnagyobb kedvezményben részesülő ország (5.4. táblázat). Ennek ellenére az EU a mai napig fontos szerepet szán fejlesztési politikájában a nemzetközi kereskedelemben való részvételnek, annak erösítésének.

5.4. táblázat Egyes régiók részesedése az EU harmadik országokkal folytatott kereskedelméböl, 1980-2005 (\%)

\begin{tabular}{|c|c|c|c|c|c|c|c|c|c|c|}
\hline \multirow[b]{2}{*}{ Régió } & \multicolumn{5}{|c|}{$\begin{array}{c}\text { Részesedés az EU } \\
\text { összimportjából (\%) }\end{array}$} & \multicolumn{5}{|c|}{$\begin{array}{c}\text { Részesedés az EU } \\
\text { összexportjából (\%) }\end{array}$} \\
\hline & 1980 & 1990 & 1995 & 2000 & 2005 & 1980 & 1990 & 1995 & 2000 & 2005 \\
\hline ACP-országok & 8,1 & 4,7 & 3,6 & 2,7 & 4,6 & 8,5 & 4,4 & 3,1 & 2,8 & 4,7 \\
\hline $\begin{array}{l}\text { Dinamikusan fejlődő } \\
\text { ázsiai gazdaságok }\end{array}$ & 5,1 & 8,2 & 10,0 & 10,5 & 9,8 & 3,8 & 7,9 & 11,4 & 8,6 & 8,2 \\
\hline Kelet-Közép-Európa & 4,5 & 5,4 & 8,7 & 9,9 & $2,5^{*}$ & 7,1 & 6,2 & 10,3 & 13,2 & $4,6^{*}$ \\
\hline Latin-Amerika & 6,6 & 6,1 & 5,6 & 4,7 & 5,5 & 6,7 & 4,3 & 5,7 & 5,8 & 5,1 \\
\hline Mediterrán-medence & 9,1 & 10,0 & 8,3 & 8,5 & 9,9 & 14,6 & 12,4 & 11,3 & 11,5 & 12,0 \\
\hline
\end{tabular}

*: az EU-tag kelet-közép-európai országokat már nem tartalmazza az adat.

Dinamikusan fejlődö ázsiai gazdaságok: Thaiföld, Malajzia, Szingapúr, Dél-Korea, Tajvan, Hongkong

Forrás: Saját szerkesztés EC (2002, 2008e) alapján

A következőkben ezek alapján azt vizsgáljuk meg, hogy az Európai Unió sokkal koncentráltabb segélyezési tevékenysége, nevezetesen az Aid for Trade keretében nyújtott támogatások mennyiben járulnak hozzá a fejlődő országokkal folytatott kereskedelmük bővüléséhez, ami végül gazdasági fejlődéshez vezethet. Mindennek elemzése azért is fontos, mert az EU is leszögezte hivatalos dokumentumaiban, hogy ha szükséges, akkor segíti a kínálatoldal fejlesztését a hatékonyabb kereskedelem érdekében. Ez pedig egyértelmüen az Aid for Trade kezdeményezés elsődleges célja. A dolgozat korábbi fejezeteiben azt is láthattuk, hogy az AfT egyre több (nemzetközi) kutatás fókuszába került, viszont ezek a kutatások az Európai Unióval mint donorral külön nem foglalkoznak. Így az Európai Unióból származó Aid for Trade vizsgálata lehetővé teszi azt, hogy az EU tevékenységéről sokkal átfogóbb képet kapjunk.

Az Európai Unióból származó Aid for Trade támogatásoknak a recipiens országok és az EU közötti kereskedelemre gyakorolt hatásait gravitációs modell segítségével vizsgáljuk. Először részletezzük a vizsgálatba bevont országok körét, valamint az Aid for Trade mérési lehetőségeit. Ezek után a gravitációs modell általános bemutatása mellett az elemzésünk során 
alkalmazott modellt ismertetjük. Végül az eredményeinket és az azokból levonható következtetéseket tekintjük át.

\subsubsection{A RECIPIENSEK ÉS A DONOROK. A SEGÉLYEK NAGYSÁGÁNAK MÉRÉSE}

Az Európai Unió által biztosított Aid for Trade támogatások lehetséges hatásainak elemzése során két irány mentén határoztuk meg a vizsgálandó országok sokaságát. Egyrészt célunk az volt, hogy minél több fejlődő országot mint fogadó országot (recipienst) vonjunk be a vizsgálatba. A másik fö szempontunk az volt, hogy a dolgozat 4.3. fejezetében bemutatott vizsgálat sokasága a maga 79 országával és az új sokaságunk között minél nagyobb legyen az átfedés, ezzel is minél jobban megteremtve a kapcsolatot a két empirikus vizsgálat között. Elsődleges célunk természetesen az volt, hogy az átfedés 100 százalékos legyen, azonban e törekvésünket akadályozta a segélyezési adatok elérhetősége.

Ennek eredményeként némileg módosítottuk a fenti célunkat. Ennek értelmében azokat az országokat vontuk be a vizsgálatba, melyek a 2005 és 2010 közötti időszakban részesültek Aid for Trade támogatásban az Európai Uniótól, és kiszürtük azokat az országokat, amelyek egyáltalán nem kaptak ilyen jellegü pénzügyi támogatást az EU-tól. Ezek végiggondolása és átnézése után a dolgozat 2.1. fejezetében bemutatottak alapján a 123 fejlődő országból 85-öt sikerült bevonnunk az elérhető adatok alapján, melyek közül 43 ország tartozik az ACP országok csoportjába, illetve 34 legkevésbé fejlett ország szerepel a mintában, melyek közül 27 egyben ACP-ország is (5.3. ábra). Az előző vizsgálatunkban szereplő országok közül 60 szerepel ebben az elemzésben is, így 75 százalékos átfedést sikerült biztosítani. ${ }^{97}$

5.3. ábra A vizsgálatban szereplő országok jellemzői

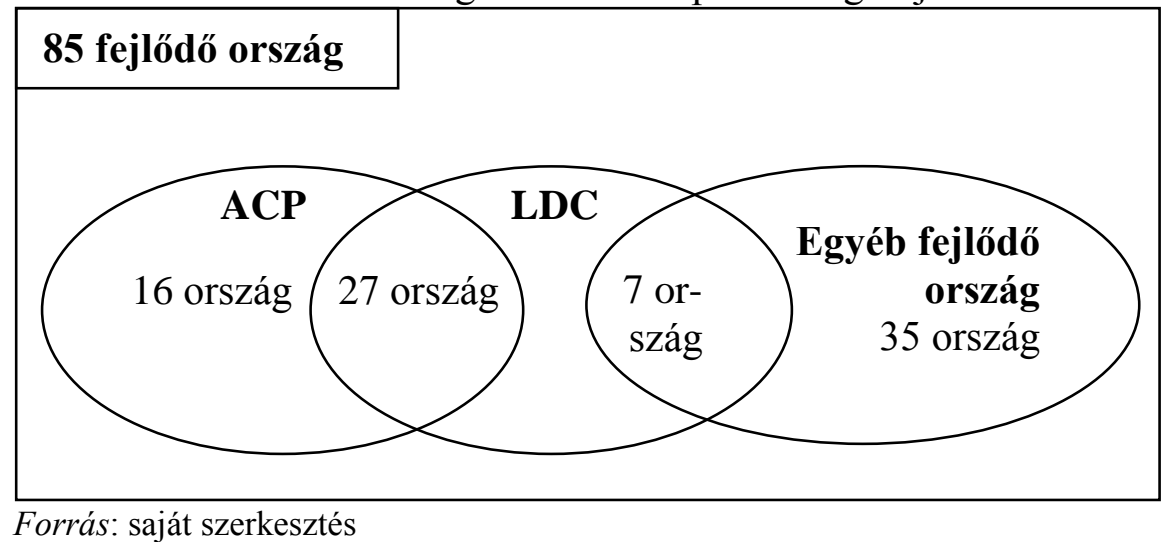

\footnotetext{
${ }^{97}$ A vizsgálatban szereplő országok köre a 3. számú mellékletben található.
} 
Mivel az Európai Unióból érkező támogatások jelentik a vizsgálatunk tárgyát, így a donor országok is az EU-ból kerülnek ki, más országokat nem vontunk be. A donorok körének meghatározása során az OECD Fejlesztési Bizottsága (Development Assistance Comittee) jelentette az alapot, hiszen az adatbázis az OECD DAC-országokra vonatkozóan tartalmaz adatokat segélyezési tevékenységre vonatkozóan. E bizottságnak az EU 15 régi tagállama a tagja, azonban egy új tagállam sem az (OECD DAC 2011). Ennek következtében az EU 15 régi tagállamainak támogatásait vettük alapul. Bár az OECD adatbázisa tartalmazza az EU Intézményeket mint donort, viszont egyetlen évre és egyetlen országra sem volt elérhető adat e donort illetően, így értelemszerüen kihagytuk az elemzésünkből. Ebből következően az EU-15 jelenti az európai fejlesztési politika értékelésének alapját.

Ahogyan arra a dolgozat 5.4. fejezetében kitértünk, az új tagállamok nem folytatnak jelentős mértékü segélyezést, különösen nem a távolabb elhelyezkedő fejlődő országok irányába, így egyértelműen elfogadható az, hogy az európai segélyezést az EU-15-ök alapján határozzuk meg. Mivel a Lisszaboni Szerződés 210. cikke lefekteti, hogy a hatékonyabb fejlesztési politika érdekében a tagállamok és a közösség összehangolják fejlesztési tevékenységüket, így az EU-15 elkülönült tevékenységének összevont vizsgálatát nem tekintjük torzító tényezőnek. ${ }^{98}$ E 15 ország segélyezési tevékenységében is vannak különbségek, más-más érdekek motiválják, motiválhatják őket (Paragi et al 2007): valamelyik ország jelentős gyarmattartó volt, míg más ország nem, valamelyik ország szorosabb kapcsolatot ápol a fejlődő országokkal, míg mások nem. Viszont a harmonizációs törekvések ismeretében mégis érdemes őket „egy kalap alá venni”. További érvként hozható fel az EU-15 egységként történő kezelése mellett az a megközelítési mód, ahogyan az EU-t a világ legnagyobb donorának tekintik. Ugyanis az EU úgy nyeri el ezt a címet, hogy a 27 ország segélyezési tevékenységét összegzik és kiegészítik a közösségi tevékenységgel. Ugyan a nyújtott segély az adott donor és a recipiens közötti kereskedelmet élénkíti, viszont ez megjelenik az EU kereskedelmi statisztikáiban is. Összességében a vizsgálati célunkhoz teljes mértékig illeszkedik az, ha az EU tevékenységének értékelését az EU-15 tevékenységére alapozzuk.

Az elemzésünk további sarkalatos pontja az Aid for Trade keretében nyújtott támogatások mérésének lehetőségei. ${ }^{99}$ Mivel nincs közvetlen statisztikai adatgyüjtés az AfTtámogatások nagyságáról, Turner (2008) átfogó elemzését vettük alapul azok

\footnotetext{
98 Szent-Iványi (2009b) is hasonló elemzési módszert követett, amikor a Visegrádi országok segélyezési tevékenységét összevontan vizsgálta.

${ }^{99}$ Erre a problémára utaltunk a dolgozat 3.3.1. fejezetében.
} 
számszerüsítésének lehetőségeiről. A szerző javaslatai közül a leginkább elfogadott módszert követtük: az OECD CRS ${ }^{100}$ (2011) ajánlásait tekintettük kiindulási pontnak, hiszen az OECD segélyezési adatbázisát széles körben használják. Emellett az OECD adatbázisa bár még nem tartalmaz egyértelmü adatokat az AfT nagyságáról, szektorális bontása alapján megközelítőleg mégis meg tudjuk adni annak nagyságát (5.5. táblázat). ${ }^{101}$

5.5. táblázat Az Aid for Trade adatai az OECD adatbázisában

\begin{tabular}{|c|c|c|}
\hline AfT területei & OECD kategóriái & Alszektorok az OECD-CRS-ben \\
\hline $\begin{array}{c}\text { kereskedelemmel } \\
\text { összefüggő infrastruktúra }\end{array}$ & gazdasági infrastruktúra & $\begin{array}{l}\text { szállítás és raktározás* } \\
\text { kommunikáció* } \\
\text { energia-ellátás* }\end{array}$ \\
\hline $\begin{array}{c}\text { termelő kapacitás } \\
\text { kiépítése és } \\
\text { kereskedelem-fejlesztés }\end{array}$ & $\begin{array}{l}\text { termelő kapacitás } \\
\text { kiépítése }\end{array}$ & $\begin{array}{c}\text { bank- és pénzügyi szolgáltatás* } \\
\text { üzleti és egyéb szolgáltatás* } \\
\text { mezőgazdaság* } \\
\text { erdészet } \\
\text { halászat } \\
\text { ipar* } \\
\text { bányászat és ásványi források } \\
\text { turizmus }\end{array}$ \\
\hline $\begin{array}{c}\text { kereskedelempolitika és } \\
\text { szabályozás }\end{array}$ & $\begin{array}{l}\text { kereskedelempolitika és } \\
\text { szabályozás }\end{array}$ & kereskedelempolitika és szabályozás* \\
\hline
\end{tabular}

Az OECD ajánlásai szerint az AfT területei négy kategória alapján megtalálhatók az adatbázisban. A kereskedelemmel összefüggő alkalmazkodási támogatások nem jelennek meg az adatbázisban, így ezt a területet - a fellelhető empirikus szakirodalmakhoz hasonlóan - az elemzésünkből kihagyjuk. Bár a termelő kapacitás kiépítésére nyújtott támogatás nagysága számos alszektor összege, vizsgálatunkból adathiány miatt ki kellett hagynunk néhány szektort. Ha mindegyiket figyelembe vettük volna, akkor jelentősen csökkent volna a vizsgálatba bevonható országok köre, így inkább a részterületek szelektálása mellett döntöttünk. Ezt indokolta az is, hogy ezekre a területekre - az elérhető adatok alapján arányaiban lényegesen kevesebb támogatás érkezett a többihez képest, így kihagyásuk nem tekinthető torzító hatásúnak.

A segélyezési adatok az OECD adatbázisában kétféle megközelítés alapján érhetők el: egyrészt szerepelnek a kötelezettségvállalások (commitments), valamint megtalálhatók a ténylegesen kifizetett összegek (disbursement) is. A kötelezettségvállalások a donorország

\footnotetext{
${ }^{100}$ Creditor Reporting System

${ }^{101}$ Hasonló elemzési módszert követ Cali és te Velde (2011), valamint Vijil és Wagner (2010) is. Megjelenik továbbá Hoekman és Wilson (2010), illetve Helble et al (2009) munkájában is.
} 
kormánya vagy hivatalos ügynökség által tett írásos kötelezettségvállalás az összegről, a fizetési feltételekröl és a felhasználás módjáról. A ténylegesen kifizetett összegek pedig már a fogadó ország rendelkezésére bocsátott összegeket jelenti (OECD CRS 2011). Az Aid for Trade hatásainak elemzésével foglalkozó empirikus kutatások nem egységesek a tekintetben, hogy a kötelezettségvállalások vagy a már kifizetett összegeket kellene-e használni. Például Cali és te Velde (2011) elemzésükben ez utóbbi összegeket vizsgálják, viszont Vijil és Wagner (2010) a kötelezettségvállalásokat vették alapul. Áttekintve az adatbázist, az empirikus elemzéseket, az elérhető adatokat mennyiségét, úgy döntöttünk, hogy a kötelezettségvállalásokat tekintjük alapnak a saját empirikus vizsgálatunk során.

Fontos megemlíteni az OECD adatbázisának legnagyobb gyengeségét: nem kezelik elkülönülten az AfT keretében biztosított támogatásokat, és nem adott olyan határérték sem, amely mellett azt mondhatnánk, hogy az adott támogatás inkább Aid for Trade-nek minősül, semmint „tipikus” fejlesztési támogatásnak (Bearce et al 2010). Bearce és szerzőtársai (2010) lényegében ezen okok miatt az Egyesült Államokra vonatkozó vizsgálataik során nem is az OECD adatbázisát használták, hanem az USA saját Aid for Trade-statisztikáit vették alapul. Hasonló adatok az Európai Unió tagországaira nem érhetők el, így a kutatók többsége által elfogadott módszert követjük, és az OECD adatbázisában szereplő adatokat tekintjük irányadónak vizsgálataink során.

\subsubsection{MÓDSZERTANI HÁTTÉR: A GRAVITÁCIÓS MODELL}

Az Aid for Trade hatásainak elemzése az ún. gravitációs modell segítségével történik. A gravitációs modell alkalmas egy adott ország potenciális külkereskedelmének megbecsülésére (Gács 2007), és lehetőséget biztosít arra, hogy megállapítsuk: két ország/térség között a tényleges kereskedelem meghaladja-e vagy alulmúlja-e a modell alapján előrejelzett kereskedelmet (Carey et al 2007). ${ }^{102} \mathrm{Az}$ elörejelzett (becsült) kereskedelem lényegében két tényezö összegeként fogható fel: az egyik a potenciális kereskedelem (kereskedelmi akadályok nélkül megvalósuló kereskedelem), a másik pedig a kereskedelmet csökkentő faktorok (kereskedelem előtt álló akadályok) (Wagner 2003). A modell ezáltal lehetőséget teremt arra, hogy olyan tényezőket is számba vegyünk, mint a

\footnotetext{
102 Dusek (2003) tanulmányában ugyan felhívja arra a figyelmet, hogy a gravitációs modell alkalmazása a tartalmi háttér hiánya miatt nem teljesen elfogadható a nemzetközi áruforgalom modellezésére (a távolság mérésének, az áruforgalom pénzbeli kifejezésének és a területközi kereskedelem problematikája miatt), viszont széles körü elterjedtsége miatt mégis a modell használata mellett döntöttünk.
} 
szabad kereskedelmi övezethez tartozás, a közös gyarmati múlt, közös nyelv, a piac nagysága, vagy esetlegesen a szállítás költsége (Anderson 2001, Gács 2007).

A gravitációs modell az elmúlt évtizedek során többféle változaton ment keresztül (Dusek 2003), Wagner (2003) alapján a két legfontosabb tényező a modellben a GDP nagysága, valamint a két partner közötti földrajzi távolság, azonban kiemeli azt is, hogy némely kutatók az egy före jutó GDP-t is beleveszik vizsgálataikba. A továbbiakban e szerint járunk el, így az alábbi regressziós modellt tekintjük a bilaterális kereskedelem gravitációs alapmodelljének (Africano és Magelhães 2005):

$$
\ln X_{i, j}=\beta_{0}+\beta_{1} \ln \left(Y_{i} \times Y_{j}\right)+\beta_{2} \ln \left(Y c_{i} \times Y c_{j}\right)+\beta_{3} \ln D i s t_{i, j}+\varepsilon,
$$

ahol $X_{i, j}$ a két ország közötti bilaterális kereskedelmet (exportot) mutatja, $Y_{i}$ és $Y_{j}$ a két ország GDP-je, ezek szorzata a potenciális piac nagyságát hivatott számszerüsíteni, $Y c_{i}$ és $Y c_{j}$ az egy főre jutó GDP nagysága és szorzatuk a jövedelmi pozíció és termékdifferenciálás iránti igény kifejezője. A Dist $t_{i, j}$ pedig a két ország közötti távolságot jelzi, mely a szállítási költség proxyjaként is felfogható. A $\beta_{i}$ pedig az egyes változók megbecsülni kívánt paraméterei (koefficiensei), az $\varepsilon$ a hibatag.

A gravitációs modell alkalmazása a kereskedelem elemzését illetően nemzetközi elemzésekben már széles körben elterjedt, ezek közül csak néhányat kiemelve szemléltetésként: Africano és Magelhães (2005) az alapmodellt kiegészítve a külföldi tőkeáramlás hatásait elemezte Portugália és az OECD-országok vonatkozásában. Persson és Wilhelmsson (2006) az EU és a fejlődő országok közötti kereskedelmet vizsgálta, figyelembe véve a különböző kereskedelmi preferenciákat. Vijil és Wagner (2010) az Aid for Trade támogatások intézményi oldalának hatásait elemezte a partnerek közötti kereskedelem alakulására vonatkozóan. Aiello és Cardamone (2010) az EBA (Fegyverek kivételével mindent) kezdeményezés hatásait vette figyelembe saját gravitációs modelljükben. Cipollina és szerzőtársai (2010) pedig az EU-s és az amerikai kereskedelmi preferenciák összehasonlítására használták a gravitációs modellt. Filippini és Molini (2003) a kelet-ázsiai kereskedelmet meghatározó tényezőket számszerüsítették a modell segítségével, melyben az országok közötti techonológiai szakadékot is figyelembe vették. De Jong és Bogmans (2011) pedig az importőr és exportőr ország korrupciós szintjét is figyelembe vette a nemzetközi kereskedelem alakulásának elemzése során. A hazai szakirodalomból Jakab és szerzőtársai (2000) munkája emelhető ki, akik három kelet-közép-európai ország egyensúlyi külkereskedelmét vizsgálták. 
A segélyek hatásainak empirikus elemzése is bővelkedik gravitációs modellen alapuló vizsgálatokban. Például Berthelemy és szerzőtársai (2009) a segélyek migrációra gyakorolt hatásait elemzik, vagy Kimura és Todo (2010) a segélyek és az FDI alakulása közötti kapcsolatot elemzik gravitációs modellel. Jelen dolgozat témája szempontjából viszont fontosabbak Wagner (2003), valamint Cali és te Velde (2011), illetve Nowak-Lehman D. és szerzőtársai (2011) vizsgálatai, hiszen ők már a segélyezés különböző aspektusait is belevették a gravitációs modell alapján készült elemzésükbe. Wagner (2003) tanulmánya alapján a modellünk építése során fontos tanulság, hogy a donor országok exportja a segélyek révén megnő (mind közvetlenül, mind pedig közvetetten), mely előrejelzi, hogy a fogadó országok (fejlődő országok) importjára is hatással vannak a támogatások, így a modellünkben ezt is figyelembe kell vennünk. Valamint Wagner (2003) tanulmánya bemutat egy lehetőséget arra, hogy hogyan lehet megfelelően azt kezelni, ha a segély nagysága egy adott országban nulla volt, így a modellünk építése során a szerző által javasolt - és a Cali és te Velde (2011) szerzőpárosok által követett - módszert átgondolásra érdemesnek tartottuk (a későbbiekben részletezzük).

A regressziós modellünk építése során nem hagyhattuk figyelmen kívül az endogenitás problémáját, azaz amikor a függő és a független változó között ellentétes irányú kapcsolat is lehet (Gács 2007). Például: nem egyértelmü, hogy a segélyek növekedése okozza a gazdasági növekedést, vagy a gyorsabb gazdasági növekedéssel rendelkező országok vonzanak több segélyt (Roodman 2007). Empirikus vizsgálatunkra ezt levetítve: nem egyértelmü, hogy a segély növeli-e meg a kereskedelmi teljesítményt, vagy a jobb kereskedelmi teljesítmény (azaz a jobban teljesítő ország, fontosabb kereskedelmi partner) eredményez nagyobb összegü segélyt. A torzító hatása miatt az endogenitást kezelni kell.

A szakirodalomban többféle megoldási móddal lehet találkozni. Gyakori, hogy öthatéves átlagokkal számolnak (például Berthelemy et al 2009, Hansen és Tarp 2001), de ez az esetünkben a megfigyelt esetek számának jelentős csökkenéséhez vezetne a rövid időtáv miatt (425 megfigyelés helyett mindössze 85 megfigyelés lenne). Másik megoldás lehet ún. instrumentális változó bevonása az elemzésbe. Olyan változót kell keresni, ami a kérdéses független változóval kapcsolatban van, viszont a megmagyarázni kívánt eredményváltozóval nem, így a függő változóra gyakorolt hatása kizárólag a független változóval meglévő kapcsolata miatt mutatható ki (Acemoglu et al 2009, Roodman 2007). Ezt a megoldási módot használták például Acemoglu és szerzőtársai (2009) és Angeles és Neandis (2009) elemzésükben. Előbbiek az intézmények és az egy főre jutó GDP közötti kapcsolatot 
vizsgálták. Mivel nem egyértelmü az intézmények és a GDP viszonya, az intézmények instrumentális változójaként a gyarmati időszakban lévő halálozási arányt is bevonták elemzésükbe. Angeles és Neandis (2009) olyan exogén változókat vontak be az elemzésükbe, mint a közös határ vagy közös nyelv. Vagy Grange és szerzőtársai (2009) proxy mutatókat használtak az endogenitás problémájának elkerülése érdekében. Viszont előfordulhat az, hogy ezek az instrumentális változók rosszul írják le az eredeti indikátort, ezzel pedig további torzítást okoznak (Roodman 2007, Younas 2008).

A segélyezéssel foglalkozó irodalomban a leggyakoribb eszköz az endogenitás kezelésére a késleltetett változókkal történő számítás (például Kimura et al 2012, Younas 2008). Ugyanakkor nincs egyetértés sem a késleltetés használatában, sem pedig a késleltetés mértékében (Doucouliagos and Paldam 2007). Cali és te Velde (2011) az Aid for Trade támogatások kereskedelmi költségek alakulására gyakorolt hatásainak elemzése során egy évvel késleltetett adatokkal számoltak. Bearce és szerzőtársai (2010) eredményei szerint az USA-ból származó Aid for Trade exportra gyakorolt hatása két évvel később jelentkezik, mint amikor a támogatást nyújtották. Azonban figyelemre méltó Wagner (2003) munkája is, aki mindkét elemzést elvégezte, és arra jutott, hogy a kötött segélyek esetében az adott évi segélyek játszottak meghatározó szerepet a donor országok exportját (azaz a fogadó országok importját) illetően. Nowak-Lehman D. és szerzőtársai (2010) szintén többféle módszert kipróbáltak. Viszont a segélyezés hatékonyságával foglalkozó szakirodalom többségében egy vagy két évvel késleltetett segélyezési adatokkal találkozunk ${ }^{103}$, azaz a segélyek hatásait annak érkezése után egy-két évvel lehet érezni (számszerüsíteni).

Mindezek alapján úgy döntöttünk, hogy a probléma kezelése érdekében a bevett gyakorlatot követjük, és egyéves késleltetett adatokkal számolunk. Ezt az összes független változó esetében figyelembe vesszük. Ennek gazdasági értelme, hogy a korábbi teljesítmény határozza meg az adott évi kereskedelmi teljesítményt, és az előző évben kapott Aid for Trade támogatás hatásai a következő évi kereskedelemben jelennek meg.

Mindezeket figyelembe véve az Európai Unióból érkező Aid for Trade támogatások hatásainak elemzése során az (1) egyenlet alapján az alapmodell empirikus vizsgálatunk során az alábbi formát ölti:

$$
\begin{aligned}
& \ln T T_{i, e u}=\beta_{0}+\beta_{1} \ln \left(Y_{i} \times Y_{e u}\right)+\beta_{2} \ln \left(Y c_{i} \times Y c_{e u}\right)+\beta_{3} \ln D i s t_{i, e u}+ \\
& +\beta_{4} T_{2006}+\beta_{5} T_{2007}+\beta_{6} T_{2008}+\beta_{7} T_{2009}+\beta_{8} T_{2010}+\varepsilon
\end{aligned}, \text { ahol }
$$

\footnotetext{
${ }^{103}$ Lásd Doucouliagos és Paldam (2007) összefoglaló tanulmányát a segélyezés irodalmáról.
} 
- $T T_{i, e u}$ a teljes kereskedelmi forgalmat (export és import összege) jelöli $i$ ország és az EU között;

- $Y_{i} \times Y_{e u}$ az $i$ fejlődő országa és az EU teljes GDP-jének szorzata;

- $Y c_{i} \times Y c_{e u}$ az $i$ fejlődő ország és az EU az egy före jutó GDP-jének szorzata;

- Dist ${ }_{i, e u}$ az $i$ fejlődő ország és az EU közötti távolságot mutatja;

- $T_{2006}, T_{2007}, T_{2008}, T_{2009}, T_{2010}$ a 2006 és 2010 év közötti éveket jelöli dummy változóval, ahol 1 jelöli, hogy az adott évről van szó, míg 0 ennek ellenkezője. A függvényszerű kapcsolat elkerülése érdekében a 2006-os évet vettük bázisnak, így azt végig 0 -val jelöltük;

- $\quad \beta_{i}$ a magyarázó változók együtthatói (koefficiensei);

$-\varepsilon$ a hibatag.

Kiemelendő, hogy a szokásos segély-export vizsgálatokkal ellentétben az elemzésünkben a függő (eredmény-) változó a teljes kereskedelem nagysága az export volumene helyett, hiszen a szakirodalom tanúsága szerint a segélyek áramlása az export- és importteljesítményre is hatással van (a fogadó ország szempontjából). Ahogyan Wagner (2003) következteti, a segélyek növelik a donor országok exportját a fogadó országok irányába, így az AfT szempontjából a segélyeknek nem csak az exportra (mint az elsődleges cél), hanem a teljes kereskedelemre nézve lehet hatásuk.

A távolság mint magyarázó tényező szintén bővebb kiegészítést igényel. A CEPII (2011) adatbázisa 223 ország vonatkozásában tartalmazza a bilaterális távolság adatokat, melyek ortodromikus távolságok ${ }^{104}$ és kilométerben szerepelnek, kiszámításának alapja a szélességi és hosszúsági fok. A távolságok kétféle megközelítésben szerepelnek az adatbázisban: egyrészt a két ország fővárosának távolságai, másrészt pedig a két ország legnépesebb városainak távolságai. Emellett súlyozott távolságadatok is szerepelnek, ahol egy-egy országból több várost is bevontak a számításba. Vizsgálatunk során a fôvárosok közötti távolságokat vettük alapul, hiszen ez széles körben elfogadott hasonló típusú vizsgálatok során. Viszont az adatbázis az EU-t mint egységet nem tartalmazza, így át kellett gondolnunk, hogy az adott fejlődő ország és az EU közötti távolságot miként határozzuk meg az adatbázis távolságadatai alapján. E probléma megoldása során felmerült a legközelebbi és a legtávolabbi EU-tagországtól mért távolság egyszerü számtani átlaga, viszont ebben az

\footnotetext{
104 Angolul orthodromic distance vagy great circle distance. A földfelszín $x$ és $y$ pontja közötti legrövidebb távolság, amit Föld felszínén a két pontot összekötő fökör mentén mérnek (Deza és Deza 2006).
} 
esetben az összes fejlődő országunk fővárosa esetében változó ponthoz viszonyítottunk volna (más pont lett volna az EU „fővárosa”), így ezt a lehetőséget elvetettük.

Annak érdekében, hogy fix viszonyítási pontot tudjunk meghatározni, az EU legfőbb gazdasági hatalmait vettük alapul, melyek közül végül Németország mellett döntöttünk. Németország ugyanis számos fejlődő ország kiemelkedő kereskedelmi partnere, valamint az EU meghatározó gazdasági ereje. Brüsszel mint az EU politikai központja („fővárosa”) is lehetséges megoldásként szerepelt, így az elemzésünket a belga (Brüsszel és az adott fejlődő ország fővárosa közötti) távolsággal is lefutattuk, azonban szignifikáns különbség nem található a belga és a német távolság hatásai között, így a német változatot tekintjük elsődlegesnek. Összegezve: a gravitációs modellben szereplő távolság magyarázó tényező esetében az adott fejlődő ország fővárosa és Németország fővárosa közötti távolságot vettük át a CEPII (2011) adatbázisából.

Az alapmodell (2) kizárólag a bilaterális kereskedelem főbb tényezőinek hatásait elemzi. Ezt kiegészítve a teljes Aid for Trade támogatással és egyéb dummy változókkal, az alábbi modell alapján történt az Aid for Trade támogatások lehetséges hatásainak elemzése:

$$
\begin{aligned}
& \ln T T_{i, e u}=\beta_{0}+\beta_{1} \ln \left(Y_{i} \times Y_{e u}\right)+\beta_{2} \ln \left(Y c_{i} \times Y c_{e u}\right)+\beta_{3} \ln \text { Dist }_{i, e u}+\beta_{4} \ln A f T+ \\
& +\beta_{4} T_{2006}+\beta_{5} T_{2007}+\beta_{6} T_{2008}+\beta_{7} T_{2009}+\beta_{8} T_{2010}+\beta_{9} A C P+\beta_{10} \text { Oil }+\beta_{11} L D C+\varepsilon,
\end{aligned}
$$

ahol az (2) egyenlethez képest újonnan bevont változók az AfT, ami az EU-ból $i$ országba érkező teljes Aid for Trade támogatások nagyságát jelöli; valamint az $A C P$, Oil, $L D C$ dummy változók, melyek rendre az ACP-, olajexportőr, legkevésbé fejlett országokat jelölik. A dummy változók esetében a nulla jelenti azt, hogy nem tartozik az adott csoportba, míg az 1 ennek ellenkezője. Törékeny államok bevonása is felmerült, viszont ez a többi változóval (ACP-országok, legkevésbé fejlett országok), szoros kapcsolatot mutatott, így pluszinformációt nem jelentene e változó bevonása. Ebből kifolyólag a legkevésbé fejlett országok dummy változója egyben az intézményi minőség változójának is felfogható.

Mivel a többi változóhoz hasonlóan az Aid for Trade támogatások mint segélyek is logaritmikus formában szerepelnek, így kezelni kellett azt, ha a támogatás nagysága nulla értéket vesz fel (hiszen nulla logaritmusa nem létezik). A Wagner (2003) tanulmányában megfogalmazott módszertani ajánlásokkal - némi fenntartással és módosítással - tudtuk kezelni azokat az eseteket, ahol az EU-ból érkező AfT-támogatások nagysága nulla volt. Wagner (2003) az egyszerü (1+segély) helyett - ennek torzító hatása miatt - azt javasolja, hogy az $\ln (\max (1$, segély $))$ alapján határozzuk meg, viszont meghatároz még egy dummy 
változót is mellé, ahol nulla jelenti azt, hogy az adott ország kapott támogatást, míg az 1 azt, hogy nem részesült külső finanszírozási forrásban. A modellünkből ezt a dummy változót kihagytuk, hiszen nem hordoz pluszinformációt, így - a korábbi jelöléseket használva - az $\ln (\max (1, A f T))$ számítási mód alapján határoztuk meg az Aid for Trade támogatások logaritmusát. A 0 és 1 közé eső segélyek kimaradásának elkerülése érdekében a támogatások nagysága ezer dollárban szerepelt a millió dollár helyett. A fenti logaritmus-formula összességében lehetővé teszi, hogy a segély szintje nulla maradjon ott, ahol már korábban is nulla volt és nem lesz kimaradt eset a vizsgálatunkban. Természetesen ugyanezt az eljárást alkalmaztuk az AfT-területek segélyeinek számítása során is.

Annak érdekében, hogy megállapítsuk, az Aid for Trade kifejezetten az ACPországokban milyen hatással bír, az AfT*ACP interakciót is szerepeltettük az egyenletben (4), kiegészítve a legkevésbé fejlett országokra vonatkozó (AfT*LDC), valamint az olajexportáló országokat jelölő (AfT*Oil) interakcióval is. Mindezek azt mutatják meg, hogy ha egy adott ország valamelyik csoportba (ACP, LDC, olajexportőr) tartozik, akkor abban a csoportban az AfT-nek milyen kereskedelembővítő hatása van.

$$
\begin{aligned}
& \ln T T_{i, e u}=\beta_{0}+\beta_{1} \ln \left(Y_{i} \times Y_{e u}\right)+\beta_{2} \ln \left(Y c_{i} \times Y c_{e u}\right)+\beta_{3} \ln D i s t_{i, e u}+\beta_{4} \ln A f T+\beta_{4} T_{2006}+ \\
& +\beta_{5} T_{2007}+\beta_{6} T_{2008}+\beta_{7} T_{2009}+\beta_{8} T_{2010}+\beta_{9} A f T * A C P+\beta_{10} A f T * O i l+\beta_{11} A f T * L D C+\varepsilon,
\end{aligned}
$$

A teljes Aid for Trade támogatások hatásainak elemzése mellett az egyes AfTterületek vizsgálata is megtörtént. Ehhez a (3) egyenletet vettük alapul, viszont az AfT változó helyett már a három AfT-részterület szerepel változóként:

$$
\begin{aligned}
& \ln T T_{i, e u}=\beta_{0}+\beta_{1} \ln Y_{i} \times Y_{e u}+\beta_{2} \ln Y c_{i} \times Y c_{e u}+\beta_{3} \ln D i s t_{i, e u}+\beta_{4} \ln E c I+\beta_{5} \ln B P C+ \\
& +\beta_{6} \ln T P R+\beta_{7} T_{2006}+\beta_{8} T_{2007}+\beta_{9} T_{2008}+\beta_{10} T_{2009}+\beta_{11} T_{2010}+\beta_{12} A C P+\beta_{13} O i l+\beta_{14} L D C+\varepsilon .
\end{aligned}
$$

A kibővített (5) egyenletben az EcI a gazdasági infrastruktúrára; a BPC a termelő kapacitás; míg a TPR a kereskedelempolitika területére érkező EU-támogatások nagyságát mutatja az $i$ országban, a többi jelölés értelemszerủen a korábban bemutatottaknak felel meg. Az Aid for Trade területek vonatkozásában is megcsináltuk a fenti interakciókat, viszont a zavaró multikollinearitás miatt ezek elemzésétől eltekintünk, és inkább az ACP és a nem ACP-országokat elkülönülten vizsgáltuk. Ez azért is indokolt, mert így az AfT területek kereskedelembővítő hatásai a két csoport esetében összehasonlíthatóvá válnak.

A gravitációs modell ugyan lehetőséget teremt olyan magyarázó változók bevonására, mint például a közös nyelv vagy gyarmati múlt, a közös határ megléte, esetleg közös pénz (például Africano és Magelhães (2005), Anderson (2001), Carey et al (2007) vagy Wagner 
(2003) munkái), az elemzésünk során alkalmazott modellekben azonban nem szerepeltettük ezeket a tényezőket. Ennek egyszerü oka az, hogy a modellünkben az EU-t egységként és nem 27 ország sokaságaként elemezzük, így azt lehet mondani, hogy az EU egy nagy gazdasági hatalom, amelynek számtalan gyarmata volt. Lényegében az empirikus vizsgálatban szereplő összes országnak volt gyarmati kapcsolata valamelyik EU-tagállammal, így nem hordozna plusz információt ez a változó. Hasonló a helyzet a közös nyelv esetében is.

A vizsgálati módszerünket, illetve annak közlését az 5.4. ábra foglalja össze: a gravitációs modellünket mind a teljes Aid for Trade támogatások hatásainak, mind pedig annak részterületeire felépítettük. A minél teljesebb kép érdekében végül minden esetben elvégeztük a számításokat az ACP- és a nem-ACP-országokra külön. Az eredmények kiszámításához az MS Excel és az SPSS 18.0 programcsomagokat használtuk. Az SPSS lehetővé teszi azt, hogy késleltetett változókkal számoljunk, és alkalmas arra, hogy a regressziós modellek feltételeinek teljesülését ellenőrizzük. A regressziós modellben minden esetben a változók bevonása az Enter módszerrel történt. A dolgozat következő fejezeteiben bemutatjuk az ezen módszer alapján kapott eredményeinket. Ennek során az egyes magyarázó változók együtthatói (koefficiensei), azok szignifikancia értékei és a modellek magyarázó ereje $\left(R^{2}, A d j . R^{2}\right)$ mellett kitérünk a sztenderdizált béták bemutatására is. Ezek az együtthatók ugyanis az egyes magyarázó változók relatív súlyát mutatják meg a modellben - rámutatva arra, hogy melyik magyarázza jobban az eredményváltozó ingadozását (Sajtos és Mitev 2007). A regressziós modellek lefuttatása során kapott egyéb eredmények (például ANOVA) az 5. és 6. számú mellékletben találhatók.

5.4. ábra Az Aid for Trade-hatások elemzésének áttekintése

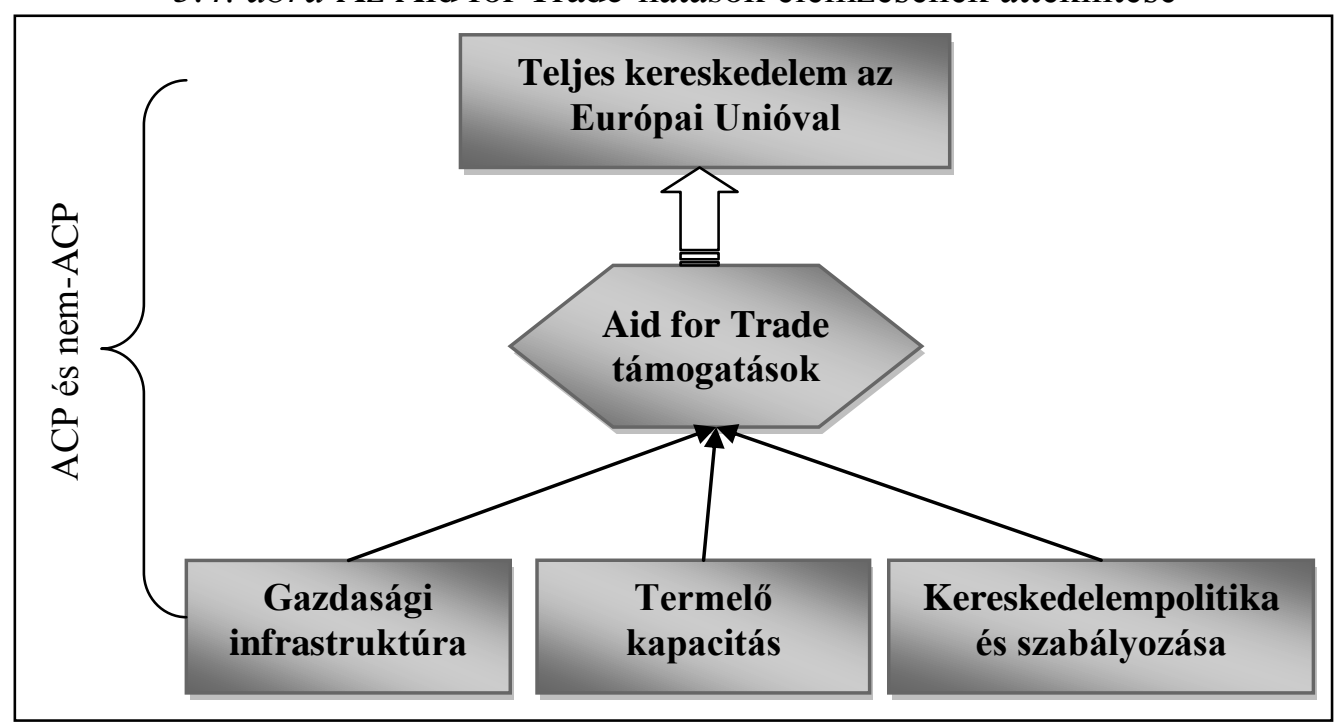

Forrás: saját szerkesztés 


\subsubsection{ELŐZETES ELEMZÉS: A VIZSGÁLT SOKASÁG MEGISMERÉSE}

A vizsgálat első lépéseként érdemes megvizsgálni leíró statisztikai módszerekkel a két csoport (ACP- és nem ACP-országok) segélyezési jellemzőit. Annak ellenére, hogy az EU az ACP-országokat tekinti fejlesztési politikájának fő kedvezményezettjének, az adatok mást mutatnak. 2005 és 2009 között a nem ACP-országok átlagosan magasabb támogatásban részesültek az Európai Uniótól, mint az ACP-országok (5.6. táblázat). Későbbi elemzésünk szempontjából az is figyelemre méltó, hogy míg az ACP-országoknál a termelő kapacitás kiépítése az elsődleges fejlesztési terület átlagosan (a teljes AfT 55,28 százaléka), addig ugyanez a nem ACP-csoport esetében a gazdasági infrastruktúra (a teljes AfT 55,56 százaléka), és ugyanez jellemző a teljes mintára is. Az is kiemelendő, hogy a kereskedelempolitika és szabályozás területére lényegesen kevesebb támogatás érkezett (a teljes AfT-támogatásoknak mindössze 1,1-1,9 százaléka).

5.6. táblázat Az ACP és a nem ACP-országok Aid for Trade támogatásai: átlagok és szórások (ezer USD)

\begin{tabular}{lccc}
\hline Változó & $\begin{array}{c}\text { ACP-országok }\left(\mathbf{n}_{\mathbf{1}}\right. \\
\mathbf{= 4 3}\end{array}$ & $\begin{array}{c}\text { Nem ACP-országok }\left(\mathbf{n}_{\mathbf{2}}\right. \\
\mathbf{= 4 2})\end{array}$ & $\begin{array}{c}\text { Teljes minta } \\
\left(\mathbf{n}_{\mathbf{3}}=\mathbf{8 5}\right)\end{array}$ \\
\hline Gazdasági infrastruktúra & $14,852(34,129)$ & $44,858(101,330)$ & $29,678(76,647)$ \\
\hline Termelő kapacitás & $19,212(27,352)$ & $34,941(57,229)$ & $26,984(45,320)$ \\
\hline $\begin{array}{l}\text { Kereskedelempolitika és } \\
\text { szabályozás }\end{array}$ & $0,687(2,379)$ & $0,949(5,460)$ & $0,817(4,191)$ \\
\hline Teljes Aid for Trade & $34,752(51,793)$ & $80,741(135,638)$ & $57,479(104,655)$ \\
\hline $\begin{array}{l}\text { Megjegyzés: } \text { a zárójelben a szórások szerepelnek } \\
\text { Forrás: saját számítás }\end{array}$ & & \\
\end{tabular}

Érdemes megvizsgálni, hogy statisztikailag szignifikáns különbség található-e az ACP-csoport és az azon kívüli országok által kapott Aid for Trade támogatások átlagai között. Mivel a változók nem normális eloszlásúak ${ }^{105}$, így a két független mintás t-teszt helyett nemparaméteres elemzési módszert alkalmaztunk az ACP és nem ACP-országok csoportátlagainak tesztelésére. A Mann-Whitney-féle U-teszt alapján az ACP és a nem ACPországok átlagai nem egyeznek meg, azaz szignifikáns különbség található közöttük, ez alól csak a kereskedelempolitika és szabályozás területére érkező támogatás a kivétel (5.7. táblázat). Mindezek az eredmények mutatják azt, hogy a teljes minta mellett szükséges az, hogy a regressziós modellünket ne csak a teljes vizsgálatai halmaz, hanem az egyes részcsoportokra (ACP és nem $\mathrm{ACP})$ vonatkozóan is elvégezzük.

\footnotetext{
${ }^{105}$ A Kolmogorov-Smirnov teszt alapján a szignifikancia a segélyezést leíró változók (logaritmikus alakjukban) esetében 0,000 értéket vett fel, így a normális eloszlásra vonatkozó nullhipotézist el kell vetni.
} 


\begin{tabular}{|c|c|}
\hline \multicolumn{2}{|c|}{ 5.7. táblázat A Mann-Whitney U-teszt eredményei } \\
\hline Változó (millió USD) & p-érték \\
\hline Gazdasági infrastruktúra & 0,000 \\
\hline Termelö kapacitás & 0,000 \\
\hline Kereskedelempolitika és szabályozás & 0,947 \\
\hline Teljes Aid for Trade & 0,000 \\
\hline
\end{tabular}

A helyes regressziós modell felállítása érdekében azt is fontos megvizsgálni, hogy van-e szignifikáns kapcsolat az eredményváltozó és a magyarázó változók között. Mivel időtényező is szerepel a vizsgálatban, így az évet kontroll változóként bevonva parciális korrelációt számoltunk (5.8. táblázat). A parciális korreláció ugyanis lehetőséget biztosít arra, hogy egy-egy változó hatásainak (jelen esetben az év, illetve annak trendhatásai) kiszürésével vizsgáljuk meg a változók közötti kapcsolat szorosságát (Sajtos és Mitev 2007). A parciális kétoldali korreláció alapján az összes szerepeltetni kívánt magyarázó változóval szignifikáns kapcsolatban áll a függő változó, azaz a teljes kereskedelem, így a regressziós modellünkben (lásd 5.5.2. fejezet) mindegyik változót célszerü szerepeltetnünk.

5.8. táblázat Korreláció a függő változó (teljes kereskedelem) és az egyes magyarázó változók között

\begin{tabular}{|c|c|}
\hline \\
\hline Változó & Korreláció (szig.) \\
\hline Páros GDP (ln) & $0,881(0,000)$ \\
\hline Páros GDP/fó (ln) & $0,482(0,000)$ \\
\hline Távolság (ln) & $-0,240(0,000)$ \\
\hline Gazdasági infrastruktúra (ln) & $0,384(0,000)$ \\
\hline Termeló kapacitás (ln) & $0,404(0,000)$ \\
\hline $\begin{array}{l}\text { Kereskedelempolitika és } \\
\text { szabályozás }(\ln )\end{array}$ & $0,144(0,003)$ \\
\hline Teljes AfT (ln) & $0,440(0,000)$ \\
\hline ACP-ország-e & $-0,440(0,000)$ \\
\hline Olajexportőr ország & $0,344(0,000)$ \\
\hline Legkevésbé fejlett ország & $-0,506(0,000)$ \\
\hline AfT*ACP & $-0,297(0,000)$ \\
\hline AfT*LDC & $-0,454(0,000)$ \\
\hline AfT *olajexportőr & $0,331(0,000)$ \\
\hline
\end{tabular}

Forrás: saját számítás

Továbbá fontos azt is megvizsgálni, hogy az egyes magyarázó változók között milyen kapcsolat áll fenn, hiszen az Aid for Trade támogatások parciális elemzése miatt elengedhetetlen az, hogy a változók közötti, illetve egy változó és változók csoportja közötti korreláció minél kisebb legyen, azaz a multikollinearitás minimális legyen. Ellenkező esetben ugyanis az egyes változók parciális elemzése értelmetlenné válik (Kovács 2008). Bár a multikollinearitás tesztelésére többféle módszer létezik (Kovács 2008), a dolgozatban a VIF- 
mutatót ${ }^{106}$ használtuk, ami a multikollinearitás elemzésének klasszikus módszereinek egyike (El-Fallah és El-Sallam 2011). Ugyan nincs egységes álláspont arra vonatkozóan, hogy a VIF mely értékét tekinthetjük még olyan szempontból elfogadhatónak, hogy a multikollinearitás ne legyen zavaró tényező a parciális elemzések során (Salahuddin és Islam 2008), a dolgozatban Kovács (2008) ajánlásait elfogadva a VIF öt feletti értékét tekintjük káros hatásúnak. A regresszióval szembeni további kitételeket is (autokorreláció, heteroszkedaszticitás) ellenőriztük. Az autokorreláció (azaz a hibatagok közötti korrelálatlanság hiányának) tesztelésére alkalmas Durbin-Watson teszt értékét minden egyes modell esetében feltüntetjük. A teszt 2 körüli értéke az autokorreláció hiányát mutatja, ami a feltétel teljesülését jelzi. Az eredmények bemutatását a teljes Aid for Trade hatásainak vizsgálatával kezdjük, majd az egyes részterületek jönnek, végezetül az ACP és a nem ACP országok részcsoportjaira vonatkozóan külön-külön elvégzett számítások eredményeit elemezzük.

\subsubsection{A TELJES AID FOR TRAde hatÁSAI A KERESKEDELEMRE - EREDMÉNYEK}

Az Európai Unióból származó Aid for Trade hatásait az EU és a fogadó országok közötti kereskedelmet illetően a teljes Aid for Trade vizsgálatával kezdtük. Négy modellt határoztunk meg - a későbbiekben is ez lesz a logikánk -, melybe fokozatosan vontuk be a vizsgálandó magyarázó változókat (5.9. táblázat). Az 1. modellt csak az alapegyenlet (1) alapján írtuk fel, azaz csak a piac nagysága (GDP), a jövedelem (GDP/fö), a távolság (szállítási költség), valamint az időtényezők dummy változói szerepeltek magyarázó változóként. A modell magyarázóereje 82,3 százalék, azaz a teljes kereskedelem szóródását 82,3 százalékban magyarázzák ezek a tényezők, amely kiváló eredménynek mondható. A magyarázó változók közül a GDP/fö mellett két év (2007 és 2008) nem szignifikáns. A piac nagysága alapján elmondható, hogy 1 százalékkal nagyobb piac 0,897 százalékkal magasabb összkereskedelmet eredményez ceteris paribus. A távolság együtthatója a vártaknak megfelelően negatív előjelü, azaz a nagyobb távolság (azaz a szállítási költség) a fogadó (fejlődő) ország és az EU között kisebb összkereskedelmet fog eredményezni. Mindemellett a 2009-ben és 2010-ben 2006-hoz (a bázisévhez viszonyítva) alacsonyabb volt a kereskedelem, ami tulajdonképpen a gazdasági válság miatti visszaesést is jelzi.

A 2. modellben már az Aid for Trade is megjelenik független változóként, a modell magyarázó ereje ezzel 83,2 százalékra emelkedett. E változó bevonásával szignifikánssá vált a

\footnotetext{
${ }^{106}$ Variance Inflation Factor - Varianciainflációs tényező
} 
jövedelmi tényező is, valamint maga az Aid for Trade is szignifikáns magyarázó változó, és a pozitív előjele miatt a segélynek kereskedelemnövelö hatása is van. E modell szerint az Aid for Trade támogatások 1 százalékos növekedése 0,112 százalékkal növeli meg az összekereskedelem értékét minden változatlansága mellett.

5.9. táblázat A regressziós modell koefficiensei (és p-értékei) - Teljes Aid for Trade

\begin{tabular}{|c|c|c|c|c|}
\hline Változó & 1. modell & 2. modell & 3. modell & 4. modell \\
\hline Konstans & $\begin{array}{l}-33,626 \\
(0,000)\end{array}$ & $\begin{array}{l}-32,986 \\
(0,000)\end{array}$ & $\begin{array}{l}-33,780 \\
(0,000)\end{array}$ & $\begin{array}{r}-33,348 \\
(0,000)\end{array}$ \\
\hline Páros GDP (ln) & $\begin{array}{c}0,897 \\
(0,000)\end{array}$ & $\begin{array}{c}0,814 \\
(0,000)\end{array}$ & $\begin{array}{c}0,832 \\
(0,000)\end{array}$ & $\begin{array}{c}0,838 \\
(0,000)\end{array}$ \\
\hline Páros GDP/fö (ln) & $\begin{array}{c}0,088 \\
(0,077)\end{array}$ & $\begin{array}{c}0,209 \\
(0,000)\end{array}$ & $\begin{array}{c}0,184 \\
(0,005)\end{array}$ & $\begin{array}{c}0,154 \\
(0,017)\end{array}$ \\
\hline Távolság (ln) & $\begin{array}{l}-0,972 \\
(0,000)\end{array}$ & $\begin{array}{l}-0,894 \\
(0,000)\end{array}$ & $\begin{array}{l}-0,903 \\
(0,000)\end{array}$ & $\begin{array}{l}-0,893 \\
(0,000)\end{array}$ \\
\hline 2007 (0: nem, 1: igen) & $\begin{array}{l}-0,034 \\
(0,801)\end{array}$ & $\begin{array}{l}-0,009 \\
(0,943)\end{array}$ & $\begin{array}{l}-0,003 \\
(0,979)\end{array}$ & $\begin{array}{c}0,002 \\
(0,989)\end{array}$ \\
\hline 2008 (0: nem, 1: igen) & $\begin{array}{l}-0,163 \\
(0,235)\end{array}$ & $\begin{array}{l}-0,196 \\
(0,143)\end{array}$ & $\begin{array}{l}-0,197 \\
(0,130)\end{array}$ & $\begin{array}{l}-0,182 \\
(0,158)\end{array}$ \\
\hline 2009 (0: nem, 1: igen) & $\begin{array}{l}-0,568 \\
(0,000)\end{array}$ & $\begin{array}{l}-0,628 \\
(0,000)\end{array}$ & $\begin{array}{l}-0,632 \\
(0,000)\end{array}$ & $\begin{array}{l}-0,609 \\
(0,000)\end{array}$ \\
\hline 2010 (0: nem, 1: igen) & $\begin{array}{l}-0,322 \\
(0,020)\end{array}$ & $\begin{array}{l}-0,370 \\
(0,006)\end{array}$ & $\begin{array}{l}-0,374 \\
(0,005)\end{array}$ & $\begin{array}{l}-0,359 \\
(0,006)\end{array}$ \\
\hline Teljes Aid for Trade (ln) & & $\begin{array}{c}0,112 \\
(0,000)\end{array}$ & $\begin{array}{c}0,131 \\
(0,000)\end{array}$ & $\begin{array}{c}0,101 \\
(0,000)\end{array}$ \\
\hline $\begin{array}{l}\text { ACP-országok } \\
\text { (0: nem, } 1: \text { igen })\end{array}$ & & & $\begin{array}{c}0,565 \\
(0,000)\end{array}$ & \\
\hline $\begin{array}{l}\text { Olajexportáló országok } \\
(0: \text { nem, } 1: \text { igen })\end{array}$ & & & $\begin{array}{c}0,186 \\
(0,111)\end{array}$ & \\
\hline $\begin{array}{l}\text { Legkevésbé fejlett országok } \\
\text { (0: nem, 1: igen) }\end{array}$ & & & $\begin{array}{l}-0,372 \\
(0,004)\end{array}$ & \\
\hline $\mathrm{AfT}^{*} \mathrm{ACP}$ & & & & $\begin{array}{c}0,061 \\
(0,000)\end{array}$ \\
\hline AfT $*$ LDC & & & & $\begin{array}{l}-0,049 \\
(0,000)\end{array}$ \\
\hline AfT*olajexportőr & & & & $\begin{array}{c}0,011 \\
(0,349)\end{array}$ \\
\hline $\mathbf{R}^{2}$ & 0,823 & 0,832 & 0,847 & 0,850 \\
\hline Adj. $R^{2}$ & 0,820 & 0,829 & 0,843 & 0,846 \\
\hline Megfigyelések száma & 425 & 425 & 425 & 425 \\
\hline VIF maximális értéke & 1,663 & 2,179 & 3,081 & 3,022 \\
\hline Durbin-Watson & 2,169 & 2,117 & 2,117 & 2,102 \\
\hline
\end{tabular}

Forrás: saját számítás

A 3. modellben az ACP-, a legkevésbé fejlett és az olajexportörök dummy változóival kontrolláltuk a modellt. Ezek közül az ACP-országok dummyja a témánk szempontjából a legfontosabb. Az ACP-országok kiemelt szerepe megállapítható: ha az ország az ACPcsoportba tartozik, akkor az EU-val folytatott kereskedelme 75,9 százalékkal 
nagyobb $^{107}$. Az ACP országok mellett még a legkevésbé fejlett országok bírnak szignifikáns hatással, viszont esetükben negatív a hatás: közel 32 százalékkal alacsonyabb a kereskedelem velük, mint a nem LDC-kkel. Azaz az EU ezekkel az országokkal nem ápol olyan szoros kereskedelmi kapcsolatot.

A 4. modell azokat az interakciókat tartalmazza, amelyekkel megállapítható, hogy kifejezetten az ACP-országoknak, a legkevésbé fejlett államoknak, illetve az olajexportőr országoknak nyújtott Aid for Trade-támogatások milyen mértékben járulnak hozzá a kereskedelembővüléshez. A három interakció közül kizárólag az ACP-országok és a legkevésbé fejlett államok esetében tapasztalható szignifikáns kapcsolat. Az ACPországokban az Aid for Trade egy százalékos emelkedése 0,061 százalékos kereskedelembővülést eredményez, míg a legkevésbé fejlett országokban az Aid for Trade nem tudja megakadályozni az EU-val folytatott kereskedelmük csökkenését.

Bár majdnem az összes változónk szignifikáns a modellben, ezek szerepe teljesen eltérő, sőt, komoly egyensúlytalanság mutatkozik a sztenderdizált együtthatók vizsgálata alapján. A sztenderdizált béták alapján a piacnak van a legnagyobb jelentősége az EU és a mintában szereplő fejlődő országok közötti kereskedelem alakulására $(0,777$ és 0,856 közötti értékeket vett fel a négy modellben). A szempontunkból lényeges segélyezési változó (Aid for Trade) mindössze 0,110-0,141 közötti sztenderdizált bétákkal rendelkezik, ezzel pedig a távolság, egyes esetekben a 2009-2010 évek után a harmadik-negyedik legnagyobb hatással bíró változó.

Eredményeink szerint tehát a teljes Aid for Trade támogatás szignifikáns és pozitív hatással bír az EU és a fejlődő országok közötti kereskedelemre. A következőkben már azt vizsgáljuk meg, hogy mindegyik Aid for Trade-terület (gazdasági infrastruktúra, termelő kapacitás, kereskedelempolitika és szabályozás) meghatározó-e ebben a folyamatban. A továbbiakban az 1. modellt, ami lényegében csak az alapváltozókat tartalmazza, nem ismételjük újra, hiszen egyértelmü, hogy ugyanarra az alapsokaságra nézve ugyanazt az eredményt fogjuk kapni. Csak abban az esetben térünk ki rá megint, ha az alapsokaságot megváltoztatjuk (ACP és nem ACP-országok csoportja).

\footnotetext{
${ }^{107}$ Számítási módja a dummy változó miatt: $e^{\beta}$.
} 


\subsubsection{AZ EGYES AFT-TERÜLETEK HATÁSAI A KERESKEDELEMRE - EREDMÉNYEK}

A teljes vizsgálati halmaz esetében a következőkben az Aid for Trade részterületeit vettük bele a regressziós modellünkbe, és az előző fejezetben bemutatottakhoz hasonlóan futtattuk le ezeket. Az Aid for Trade-területek és az országcsoportok dummy-jainak interakcióját is lefuttattuk, viszont a multikollinearitást jelző VIF mutató értéke bőven meghaladta a kritikus ötös szintet (10 fölötti értékeivel), így ennek bemutatásától eltekintünk, hiszen a parciális hatások így nem elemezhetők. Az ACP- és nem ACP-országok közötti különbségek feltárásához a két csoportot elkülönülten kezeljük majd. A regressziós modellekbe bevont magyarázó változók együtthatóit az 5.10. táblázat tartalmazza. A modellek magyarázó ereje az előző vizsgálatunkhoz hasonlóan alakul minden egyes modell esetében: a teljes kereskedelem különbözőségét közel 83-84 százalékban magyarázzák a független változók.

5.10. táblázat A regressziós modell koefficiensei (és p-értékei) - Az Aid for Trade részterületei

\begin{tabular}{|c|c|c|}
\hline Változó & 1. modell & 2. modell \\
\hline Konstans & $-32,643(0,000)$ & $-33,311(0,000)$ \\
\hline Páros GDP $(\ln )$ & $0,818(0,000)$ & $0,837(0,000)$ \\
\hline Páros GDP/fó (ln) & $0,198(0,001)$ & $0,165(0,014)$ \\
\hline Távolság $(\ln )$ & $-0,903(0,000)$ & $-0,907(0,000)$ \\
\hline 2007 (0: nem, 1 : igen) & $-0,008(0,951)$ & $-0,003(0,979)$ \\
\hline 2008 (0: nem, 1 : igen $)$ & $-0,168(0,214)$ & $-0,161(0,218)$ \\
\hline 2009 (0: nem, 1 : igen $)$ & $-0,618(0,000)$ & $-0,619(0,000)$ \\
\hline $2010(0:$ nem, 1 : igen $)$ & $-0,357(0,009)$ & $-0,358(0,007)$ \\
\hline Gazdasági infrastruktúra (ln) & $0,042(0,006)$ & $0,053(0,000)$ \\
\hline Termelö kapacitás (ln) & $0,050(0,040)$ & $0,060(0,000)$ \\
\hline Kereskedelempolitika (ln) & $0,003(0,863)$ & $-0,004(0,790)$ \\
\hline ACP-országok $(0:$ nem, 1 : igen $)$ & & $0,569(0,000)$ \\
\hline $\begin{array}{l}\text { Olajexportáló országok } \\
(0: \text { nem, } 1 \text { : igen })\end{array}$ & & $0,162(0,167)$ \\
\hline $\begin{array}{l}\text { Legkevésbé fejlett országok } \\
(0: \text { nem, } 1: \text { igen })\end{array}$ & & $-0,398(0,000)$ \\
\hline $\mathbf{R}^{2}$ & 0,831 & 0,846 \\
\hline Adj. $R^{2}$ & 0,827 & 0,841 \\
\hline Megfigyelések száma & 425 & 425 \\
\hline VIF maximális értéke & 2,337 & $\mathbf{3 , 1 9 0}$ \\
\hline Durbin-Watson & 2,129 & 2,141 \\
\hline
\end{tabular}

Forrás: saját számítás

Mindkét modellben lényegében ugyanazok a magyarázó változók tekinthetők szignifikánsnak. A GDP, a GDP/fö, a távolság, valamint az időtényező (2009 és 2010) mindenütt szignifikáns. Ami a segélyezési területeket illeti, a gazdasági infrastruktúra területére érkező támogatások mellett a termelő kapacitás fejlesztésére érkező pénzügyi 
források is szignifikánsak a teljes kereskedelem különbözőségének magyarázatát illetően, míg a kereskedelempolitika és szabályozás területének támogatása nem bír szignifikáns hatással. Mindkét terület estében a támogatások együtthatója a modell bővítésével (azaz az országcsoportok bevonásával) növekedett. Ennek alapján a gazdasági infrastruktúra területére érkező támogatások 1 százalékos növekedésével $0,042(0,053)$ százalékos kereskedelemnövekedést lehet elérni ceteris paribus.

Érdekes módon - és a szakirodalmi következtetésekkel teljesen ellentétesen - a termelő kapacitás esetében némileg nagyobb hatás tapasztalható: az erre a területre érkező támogatások 1 százalékos növelése $0,050 \quad(0,060)$ százalékos kereskedelembővülést eredményez. Összevetve ezt az előző alfejezetben ismertetett teljes támogatásokkal, látható, hogy valóban e két részterület határozza meg a teljes Aid for Trade-támogatás hatásait. Ebből következően azt lehet mondani, hogy a mintánk alapjául szolgáló 85 ország esetében az Aid for Trade támogatások összhatásait a gazdasági infrastruktúra és a termelő kapacitás területére érkező támogatások határozzák meg.

Az ACP-országok és a legkevésbé fejlett országok változóiról hasonlóak mondhatók el, mint amit már az előző fejezetben ismertettünk. Az ACP-országok minden esetben szignifikáns, pozitív, míg az LDC-k negatív együtthatóval rendelkeznek (és nincs szignifikáns különbség a teljes AfT esetében tapasztalt együtthatóktól). Mindezzel alapján az ACPországok és a legkevésbé fejlett országok jelentős szerepet játszanak az EU-val folytatott kereskedelemben, bár a legkevésbé fejlett ország-státusz negatívan befolyásolja azt. Azaz az EU a legkevésbé fejlett országokra nem fordít kiemelt figyelmet, annak ellenére, hogy az európai fejlesztéspolitikai konszenzusban és a fejlesztési politika földrajzi súlyozásának elve szerint a terület prioritását hangsúlyozták.

A sztenderdizált együtthatók vizsgálata ugyanarra az eredményre vezet, amelyre az előző fejezetben is utaltunk: minden modell esetében a páros GDP szorzatának (piac nagysága) van a legnagyobb jelentősége (0,79-et közelíti mindkét esetben), míg a két szignifikáns segélyezési terület (gazdasági infrastruktúra és termelő kapacitás) közül a gazdasági infrastruktúra területére érkező támogatásoknak van jelentősebb hatása. Viszont nem olyan nagymértékủ a különbség, mint amit a segélyek és a GDP között lehet tapasztalni. A gazdasági infrastruktúra esetében 0,069 , illetve 0,086 a sztenderdizált béta; a termelő kapacitás vonatkozásában pedig 0,057, valamint 0,069 . 


\subsubsection{AZ ACP ÉS NEM-ACP CSOPORTOK EREDMÉNYEI}

Az eddigi eredményeink az ACP-országokat illetően kizárólag azt mutatták, hogy az EU-val folytatott kereskedelem esetében szignifikáns hatása van-e annak a tényezőnek, hogy az adott ország az afrikai, csendes-óceáni, karibi térségbe tartozó állam-e. Illetve az AfT*ACP interakció rávilágított arra, hogy az ACP-országoknak nyújtott támogatás ebben a csoportban milyen hatással bír. A fenti eredmények tekintetében elfogadható az, hogy az ACP-országok EU-val folytatott kereskedelme szignifikánsan magasabb, mint a nem ACP-országoké. Viszont nem kaptunk választ arra, hogy az ACP- és a nem ACP-országok tapasztalható-e különbségek a segélyek kereskedelemgeneráló hatásait illetően. Mivel az empirikus vizsgálat célja az, hogy megállapítsuk: az EU-s Aid for Trade támogatások hozzájárulnak-e a bilaterális kereskedelem bővüléséhez és hogy ebben az ACP-országok milyen helyet foglalnak el, érdemes külön megvizsgálni az ACP- és nem ACP-országok csoportját. Ezt indokolja az is ahogy a dolgozat 5.5.3. fejezetében bemutattuk -, hogy szignifikáns különbség van az ACPés a nem ACP-országok átlagai között az Aid for Trade, illetve az egyes részterületek támogatásai között.

Így a következőkben az ACP- és a nem ACP-országokat külön vizsgáljuk, ezzel információt kapunk arról, hogy az - elvileg - ACP-preferencia az EU részéről milyen eredményeket, potenciális ok-okozati viszonyokat jelentenek az ACP-országokban, és ezek az országok mennyiben viselkednek hasonlóan a nem a legfőbb kedvezményezettnek számító egyéb fejlődő országokhoz képest. Ennek értelmében mindkét csoportra vonatkozóan elvégeztük a fenti regressziós számításokat. Ebben az esetben az 5.5.2. fejezetben szereplő (4) egyenlet annyiban módosul, hogy az ACP-ország dummy-ja már nem szerepel a magyarázó változók között. Az eredményeket a könnyebb összehasonlíthatóság érdekében egy táblázatban szerepeltetjük (5.11. táblázat). Az eredmények taglalása előtt fontos megjegyezni, hogy az ACP-országok vonatkozásában az autokorrelációt tesztelő Durbin-Watson értéke mindkét modell esetében a negatív autokorreláció jelenlétére utaló tartományba esett ( $d=2,294$, illetve $d=2,461)$. Ennek kezelése a Cochrane-Orcutt eljárással történt meg (a második, illetve a negyedik iteráció vezetett eredményes megoldásra), a táblázat már ezeket az eredményeket tartalmazza.

A kereskedelem alakulását meghatározó alapmutatók alapján a két csoport hasonlóan viselkedik: a GDP (mint piac nagysága) az ACP-csoporton kívüli országokban ugyan nagyobb hatással bír a partnerek közötti kereskedelem alakulására, valamint a 2009-2010-es években jelentősebb a kereskedelem visszaesése az ACP-országokhoz képest, a többi változó 
esetében nem tapasztalható ilyen mértékü különbség. Az Aid for Trade területeit vizsgálva viszont kiütközik a két csoport közötti különbség. Az olajexportőrök és legkevésbé fejlett országok bevonása nélkül az ACP-csoportban kizárólag a termelő kapacitás területére érkező támogatásoknak van szignifikáns hatása! Ez esetben az 1 százalékos segélynövekedés 0,125 százalékos kereskedelembővülést eredményez. A nem ACP-országokban viszont csak a gazdasági infrastruktúra fejlesztésére nyújtott támogatások játszanak szignifikáns szerepet, viszont ezek hatása kisebb, mint az ACP-országokban a termelő kapacitásoké: 1 százalékos segélynövekedés 0,066 százalékos kereskedelembővülést eredményez.

5.11. táblázat Az ACP és nem ACP országok regressziós modelljének koefficiensei (és p-értékei)

\begin{tabular}{|c|c|c|c|c|}
\hline \multirow[b]{2}{*}{ Változó } & \multicolumn{2}{|c|}{ ACP-országok } & \multicolumn{2}{|c|}{ Nem ACP-országok } \\
\hline & 1. modell & 2. modell & 3. modell & 4. modell \\
\hline Konstans & $\begin{array}{c}-30,754 \\
(0,000)\end{array}$ & $\begin{array}{c}-26,471 \\
(0,000)\end{array}$ & $\begin{array}{l}-39,544 \\
(0,000)\end{array}$ & $\begin{array}{r}-35,186 \\
(0,000)\end{array}$ \\
\hline Páros GDP (ln) & $\begin{array}{c}0,736 \\
(0,000)\end{array}$ & $\begin{array}{c}0,666 \\
(0,000)\end{array}$ & $\begin{array}{c}0,924 \\
(0,000)\end{array}$ & $\begin{array}{c}0,895 \\
(0,000)\end{array}$ \\
\hline Páros GDP/fö (ln) & $\begin{array}{c}0,376 \\
(0,000)\end{array}$ & $\begin{array}{c}0,251 \\
(0,007)\end{array}$ & $\begin{array}{c}0,233 \\
(0,006)\end{array}$ & $\begin{array}{c}0,079 \\
(0,406)\end{array}$ \\
\hline Távolság (ln) & $\begin{array}{l}-1,022 \\
(0,000)\end{array}$ & $\begin{array}{l}-0,865 \\
(0,000)\end{array}$ & $\begin{array}{c}-0,832 \\
(0,000)\end{array}$ & $\begin{array}{l}-0,803 \\
(0,000)\end{array}$ \\
\hline 2007 (0: nem, 1: igen) & $\begin{array}{c}0,011 \\
(0,946)\end{array}$ & $\begin{array}{c}0,045 \\
(0,756)\end{array}$ & $\begin{array}{l}-0,080 \\
(0,650)\end{array}$ & $\begin{array}{c}-0,055 \\
(0,750)\end{array}$ \\
\hline 2008 (0: nem, 1: igen) & $\begin{array}{l}-0,199 \\
(0,233)\end{array}$ & $\begin{array}{l}-0,125 \\
(0,402)\end{array}$ & $\begin{array}{l}-0,271 \\
(0,131)\end{array}$ & $\begin{array}{l}-0,184 \\
(0,298)\end{array}$ \\
\hline 2009 (0: nem, 1: igen) & $\begin{array}{l}-0,602 \\
(0,000)\end{array}$ & $\begin{array}{l}-0,496 \\
(0,001)\end{array}$ & $\begin{array}{l}-0,800 \\
(0,000)\end{array}$ & $\begin{array}{l}-0,672 \\
(0,000)\end{array}$ \\
\hline 2010 (0: nem, 1: igen) & $\begin{array}{c}-0,281 \\
(0,091)\end{array}$ & $\begin{array}{l}-0,195 \\
(0,188)\end{array}$ & $\begin{array}{c}-0,572 \\
(0,002)\end{array}$ & $\begin{array}{l}-0,460 \\
(0,011)\end{array}$ \\
\hline Gazdasági infrastruktúra (ln) & $\begin{array}{c}0,035 \\
(0,081)\end{array}$ & $\begin{array}{c}0,043 \\
(0,020)\end{array}$ & $\begin{array}{c}0,066 \\
(0,007)\end{array}$ & $\begin{array}{c}0,079 \\
(0,001)\end{array}$ \\
\hline Termelö kapacitás (ln) & $\begin{array}{c}0,125 \\
(0,001)\end{array}$ & $\begin{array}{c}0,141 \\
(0,000)\end{array}$ & $\begin{array}{c}0,015 \\
(0,664)\end{array}$ & $\begin{array}{l}-0,016 \\
(0,652)\end{array}$ \\
\hline $\begin{array}{l}\text { Kereskedelempolitika és } \\
\text { szabályozás }(\ln )\end{array}$ & $\begin{array}{c}0,020 \\
(0,361)\end{array}$ & $\begin{array}{c}0,023 \\
(0,261)\end{array}$ & $\begin{array}{l}-0,031 \\
(0,158)\end{array}$ & $\begin{array}{l}-0,025 \\
(0,234)\end{array}$ \\
\hline $\begin{array}{l}\text { Olajexportáló országok } \\
(0: \text { nem, } 1: \text { igen })\end{array}$ & & $\begin{array}{c}0,844 \\
(0,000)\end{array}$ & & $\begin{array}{l}-0,037 \\
(0,783)\end{array}$ \\
\hline $\begin{array}{l}\text { Legkevésbé fejlett országok ( } 0 \text { : } \\
\text { nem, 1: igen) }\end{array}$ & & $\begin{array}{l}-0,294 \\
(0,000)\end{array}$ & & $\begin{array}{c}-0,707 \\
(0,001)\end{array}$ \\
\hline $\mathbf{R}^{2}$ & 0,768 & 0,796 & 0,846 & 0,855 \\
\hline Adj. $R^{2}$ & 0,756 & $\mathbf{0 , 7 8 3}$ & $\mathbf{0 , 8 3 8}$ & 0,846 \\
\hline Megfigyelések száma & 215 & 215 & 210 & 210 \\
\hline VIF maximális értéke & $2,178^{*}$ & $2,531 *$ & 1,943 & $\mathbf{2 , 5 9 7}$ \\
\hline Durbin-Watson & 1,955 & 1,916 & 2,151 & 1,960 \\
\hline
\end{tabular}

*: A VIF maximális értéke az eredeti outputból származik, az autoregressziós korrekció nem tette lehetővé ennek újraszámolását.

Forrás: saját számítás

Amennyiben az olajexportőrök és legkevésbé fejlett országok dummy változóit kontrollként bevonjuk a modellbe, az ACP-országok körében jelentős változás történik. 
Egyrészt a termelő kapacitás támogatásainak hatása emelkedik ( $\beta=0,141)$, másrészt pedig a korábbi ingszignifikáns változó, a gazdasági infrastruktúra támogatottsága szignifikánssá vált, viszont eredményessége messze elmarad a termelő kapacitás fejlesztésének hatásaitól: 1 százalékos segélynövekedés mindössze 0,043 százalékos kereskedelembővülést eredményez. Mindemellett az ACP-országok olajexportőr országaival nagyobb kereskedelem zajlik, mint a nem olajexportörökkel.

A nem ACP-országok körében nem történt ilyen mértékü változás e két dummy változó bevonásával. A gazdasági infrastruktúra területére érkező támogatások hatása megmaradt, valamelyest emelkedett $(\beta=0,079)$, de még mindig jóval elmarad az ACPországokban tapasztalt termelő kapacitások fejlesztésének hatásaitól. A két bevont országcsoport közül kizárólag a legkevésbé fejlett országok esetében mutatható ki szignifikáns hatás - és ez sokkal nagyobb, mint az ACP-országok körébent tapasztalt hatás. Azaz az EU ugyan a legkevésbé fejlett országokkal csekélyebb kereskedelmet folytat, mint a fejlettebb országokkal, viszont ez a kereskedelem még csekélyebb, ha a legkevésbé fejlett ország nem tartozik az ACP-országok körébe.

A sztenderdizált béták vizsgálata sem hozott új eredményt. A GDP-nek van a legnagyobb szerepe (0,8 körüli értékkel). A segélyezési adatok közül csak a gazdasági infrastruktúra szignifikáns, melynek relatív hatása 0,101, illetve 0,121 az értéke a nem ACPországok vonatkozásában, ami pedig magasabb, mint amit a teljes minta vizsgálata során láthattunk. Összességében viszont a szignifikáns változók vonatkozásában a legkisebb súlyú változók közé tartozik. Ami az ACP-országokat illeti, a GDP maradt a legjelentősebb szignifikáns változó (sztenderdizált béta 0,592), viszont a termelő kapacitás kiépítése a maga 0,209-es sztenderdizált bétájával a második legjelentősebb változóvá lépett elő. A gazdasági infrastruktúra területe ugyan szignifikáns a bővebb modellben, viszont hatása jóval elmarad a termelő kapacitástól $(0,089)$.

Ezek az eredmények egyértelmüen igazolják azt, hogy az ACP és a nem ACPországokat egymástól elkülönülten kell kezelni. Viszont a gazdasági infrastruktúra területét érintő támogatások felhasználásában egyértelmüen az ACP-n kívüli országok vannak kedvezőbb helyzetben, míg az ACP-országok esetében nagyobb szerepe van a termelő kapacitás kiépítésének. Ez utóbbi azonban további vizsgálódást igényel: valóban a termelő kapacitások fejlesztése jelent pluszt az ACP-országoknak, holott ezek az országok fejletlenebbek, mint a nem ACP-országok? A szakirodalomban fellelhető elemzésektől ez 
eltérő eredmény, így a modell robusztusságának ellenőrzése - többek között - emiatt is indokolt.

\subsubsection{A MODELL ROBUSZTUSSÁGÁNAK ELLENŐRZÉSE}

A gravitációs modell az összes független és függő változót logaritmikus alakban tartalmazza. Ez lehetővé teszi azt, hogy az egyes változók kiugró értékeinek hatásait csökkentsük, hiszen a regressziós modellek érzékenyek az outlier értékekre. ${ }^{108}$ Ennek ellenére kiugró értékek maradhattak a vizsgálatban, amelyek az empirikus elemzésünk eredményeit torzíthatják. Mindez különösen igaz annál az esetnél, hogy az ACP-országokban a termelő kapacitás fejlesztésére nyújtott támogatás szignifikáns hatással bír, csakúgy, mint a gazdasági infrastruktúra területére érkező támogatás, míg ez az állítás nem igaz az ACP-csoporton kívüli országokra. A szakirodalomban fellelhető vizsgálatok között viszont csak elvétve akad olyan, amely a termelő kapacitás fejlesztésének tulajdonítanának szignifikáns hatást. Így érdemes tovább vizsgálódni és a modellt ellenőrizni: valóban így van-e az ACP-országokban és a szakirodalomtól jelentős mértékben eltérő eredmény az eltérő fogadó és donor országok sajátosságaira vezethető vissza, vagy valamilyen oknál fogva fenntartásokkal kell kezelni a korábban ismertetett eredményeket.

Mivel az empirikus elemzés során éves adatokat használtunk fel, nem pedig többéves átlagokat, a segélyezési adatok ingadozása torzíthatja az eredményeket. Így az előző fejezetekben bemutatott eredmények megbízhatóságának ellenőrzése során az Aid for Trade adatai közül a kiugró és extrém értékeket kiszürtük, ezzel mintegy kisimítottuk az adatsort. Mivel a regressziós modellben az Aid for Trade és a részterületei esetében is azok logaritmikus alakjaival számoltunk, így a kiugró értékek meghatározása is ezek alapján történt. Ehhez grafikus módszert használtunk: a boxplot-ot hívtuk segítségül (5.5. ábra). A boxplot az első és harmadik kvartilis, valamint a medián mellett mutatja az interkvartilis terjedelem másfélszeresét is (doboz széleitől induló vonal). Kiugró értékről abban az esetben beszélhetünk, ha az esethez tartozó érték a doboz szélétől $\left(\mathrm{Q}_{1}, \mathrm{Q}_{3}\right)$ számított 1,5-3 interkvartilis terjedelemben van (például az A pont az ábrán). Ha 3-nál nagyobb a terjedelem, extrém esettel állunk szemben (Sajtos és Mitev 2007).

\footnotetext{
${ }^{108}$ Ez bevett gyakorlat, lásd például Ferkelt és Gáspár (2008), Gáspár és Udvari (2011), vagy Németh és Kiss (2007) tanulmányát.
} 


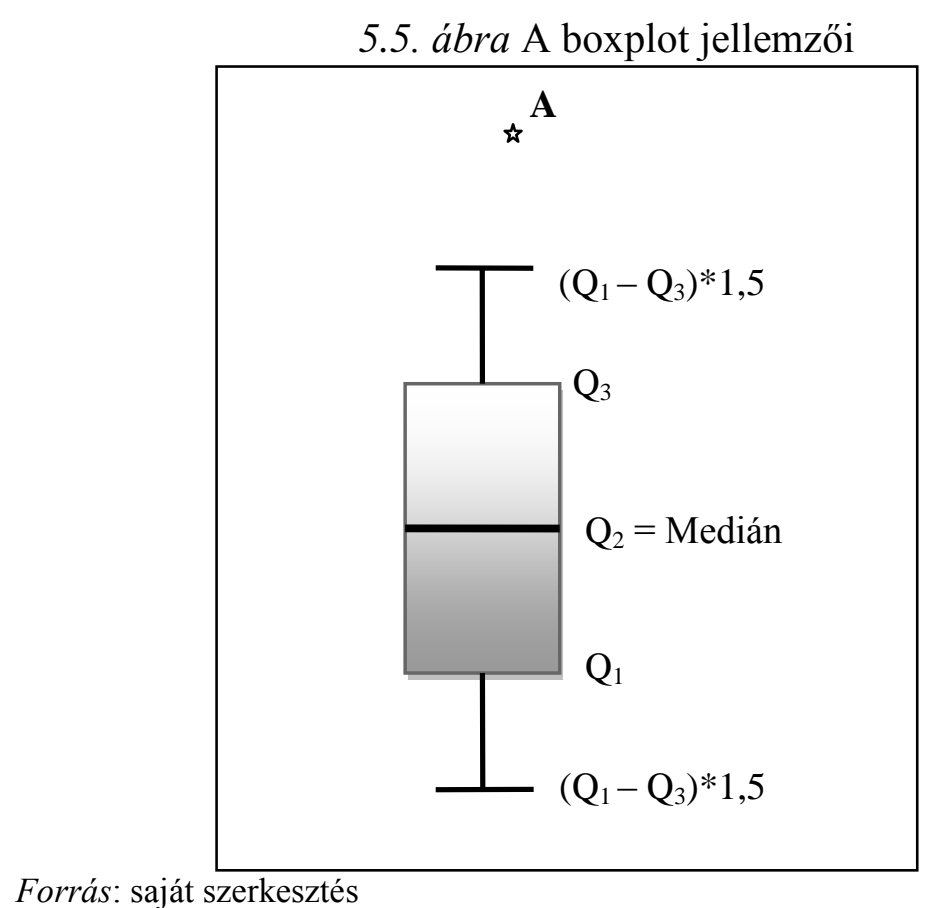

Mivel az elemzés során mind a teljes Aid for Trade, mind pedig annak részterületeit elemeztük, így kiugró értékek mindegyik területen megjelenhettek. Ezek kiszürésének elve az volt, hogy először a teljes Aid for Trade-támogatások közül vettük ki ezeket az eseteket. Majd megvizsgáltuk, hogy az egyes részterületek vonatkozásában maradt-e még az átlagosnál több vagy kevesebb értéket tartalmazó eset. A három vizsgált terület közül kizárólag a termelö kapacitás építésére érkező támogatások tartalmaztak kiugró értékeket (ne felejtsük el, hogy ez a terület a kérdéses eset a vizsgálat során!), így ezeket az eseteket kivettük a mintából. Hangsúlyozandó, hogy csak a megfigyeléseket, nem pedig az országokat hagytuk ki a későbbi elemzésből!

A kiugró esetek meghatározása és kiszürése után a mintában 399 megfigyelés maradt (a korábbi 425-ből), melyből 196 megfigyelés ACP-vonatkozású, míg 203 eset azon kívüli. Erre a mintára építve újra lefutattuk az előző fejezetekben bemutatott regressziós modelleket. Mivel jelentős mértékű egyezőség van a szignifikáns változókban, illetve azok együtthatóiban, így a következőkben kizárólag azokat az eredményeket mutatjuk be, melyek a korábbiaktól jelentős mértékben eltérnek, a többi eredmény az 6. számú mellékletben megtalálható. Az újonnan lefuttatott modellek eredményeinek áttanulmányozása és a korábbi eredményekkel történő összevetése után két olyan területet kell kiemelni, ahol jelentős eltérés található. Az egyik az AfT területeihez köthető, a másik pedig az ACP-országok elkülönült vizsgálata adja (5.12. táblázat). 
5.12. táblázat Az eltérő eredmények

\begin{tabular}{|c|c|c|}
\hline Változó & Teljes minta & ACP-országok \\
\hline Konstans & $-32,188(0,000)$ & $-31,147(0,000)$ \\
\hline Páros GDP (ln) & $0,778(0,000)$ & $0,666(0,000)$ \\
\hline Páros GDP/fö (ln) & $0,258(0,000)$ & $0,437(0,000)$ \\
\hline Távolság (ln) & $-0,800(0,000)$ & $-0,605(0,009)$ \\
\hline 2007 (0 ha nem, 1 ha igen) & $-0,031(0,814)$ & $-0,026(0,857)$ \\
\hline 2008 (0 ha nem, 1 ha igen) & $-0,182(0,171)$ & $-0,228(0,114)$ \\
\hline 2009 (0 ha nem, 1 ha igen) & $-0,669(0,000)$ & $-0,673(0,000)$ \\
\hline 2010 (0 ha nem, 1 ha igen) & $-0,361(0,007)$ & $-0,239(0,104)$ \\
\hline Gazdasági infrastruktúra (ln) & $0,050(0,001)$ & $0,039(0,035)$ \\
\hline Termelő kapacitás (ln) & $0,020(0,580)$ & $0,057(0,258)$ \\
\hline Keresk.politika és szabályozás (ln) & $0,007(0,669)$ & $0,025(0,215)$ \\
\hline $\mathbf{R}^{2}$ & 0,823 & 0,751 \\
\hline Adj. $\mathbf{R}^{2}$ & 0,818 & 0,736 \\
\hline Megfigyelések száma & 399 & 196 \\
\hline VIF maximális értéke & 2,661 & $2,178 *$ \\
\hline Durbin-Watson & 2,171 & 1,990 \\
\hline
\end{tabular}

*: A VIF mutató maximális értéke az eredeti regressziós modellből származik, az autoregresszió alkalmazása során ezt nem lehetett újra kiszámolni.

Forrás: saját számítás

A kiugró értékek kiszürése után a korábbi eredményekhez képest a legnagyobb különbség abban mutatkozik, hogy a termelö kapacitás fejlesztésére érkező támogatások már nem tekinthetők szignifikánsnak: sem a teljes minta, sem pedig az ACP-országok vonatkozásában. A gazdasági infrastruktúra továbbra is szignifikáns változó maradt, ezek együtthatója a korábbiakhoz hasonló értéket vesz fel (teljes minta: 0,042; ACP-országok: 0,035 - bár ez utóbbi nem szignifikáns a hasonló modellben). Sőt, összevetve a további változók együtthatóit a kétféle modellben, jelentős különbség nem mutatkozik. Mindezzel együtt pedig arra a következtetésre juthatunk, hogy a korábbi modellek teljes mértékben alkalmazhatók és helyes eredményre vezetnek, viszont a termelő kapacitás területére érkező támogatások elemzése nagyobb körültekintést igényel.

A dolgozatban megfogalmazott céloknak a gravitációs modell egyértelműen megfelel. Viszont a modell eredményeinek interpretálása során néhány ok miatt óvatosabban kell fogalmaznunk. Jelen esetben egyéves késleltetéssel számoltunk, viszont hosszabb idősorok esetében már érdemes a két évvel késleltetett adatokat is figyelembe venni, aminek - az endogenitás problémájának kezelése mellett - közgazdasági értelme is van: vajon elegendő egy év a segélyek olyan mértékü felhasználásához, hogy az valós kereskedelembővülést eredményez?

Továbbá az elemzésből kihagytuk azokat a fejlődő országokat, amelyek esetében nem volt elérhető segélyezési adat. Ugyan megfelelő módszerrel sikerült kezelni azokat az 
eseteket, ahol a segély értéke nulla volt valamelyik évben, viszont a teljes adatsor hiánya esetén nem tartottuk szerencsésnek ennek alkalmazását, annak ellenére, hogy az országok kihagyása szelekciós torzításhoz vezethet. Azért döntöttünk ezen országok kihagyása mellett, mert nem mindegy, hogy az adott ország ugyan kapott segélyt, csak az nem jelenik meg az adatbázisban jelentési problémák miatt, vagy az adott ország egyáltalán nem kapott pénzügyi támogatást. Ezeket nem célszerü összekeverni, és inkább a biztos háttérrel rendelkező országokkal foglalkoztunk. Mindemellett áttekintettük azon országok körét, melyek az elemzésből kimaradtak: 7 alacsony jövedelmủ, 15 alsó közepes jövedelmủ és 19 felső közepes jövedelmü ország maradt ki. E kihagyott országok között számos szigetország található (például Comore-szigetek, Marshall-szigetek, Mikronézia, St. Kitt és Nevis, Tuvalu, Vanuatu), amelyek kis ország lévén az EU-val nem folytatnak jelentős kereskedelmet, és többségük az EU-tól távol helyezkedik el. Mellettük olyan országok is kimaradtak, amelyek megsegítése nehézkes lenne (valamint elhanyagolható a kereskedelem volumene), úgy, mint Szomália, Kuba vagy Mianmar. Mindezek alapján egyértelmü, hogy az eredmények sokkal célravezetöbbek a bevont országokkal.

A gravitációs modellek, de úgy általában a regressziós modellek, hátránya az, hogy nem lehet minden tényezőt figyelembe venni, ami az adott jelenséget jól leírja, ez némileg az elemző szubjektivitására (elméleti tapasztalataira, ismereteire) van bízva, akármennyire is igyekszünk kiszürni a szubjektivitást a modellből. Az eredmények elemzése során így figyelembe kell venni azt is, hogy olyan tényezők is szerepet játszhattak a kereskedelem, segélyek alakulásában, illetve a segélyek kereskedelemre gyakorolt hatásában, melyeket a regressziós modellben nem szerepeltettünk. Ennek következtében a kedvezőbb (vagy kedvezőtlenebb) eredmény ezeknek is betudható. Ezek további vizsgálatot igényelnek, viszont ez már jóval túlmutat jelen disszertáció céljain, lehetőségein.

\subsubsection{AZ EU-S AFT EMPIRIKUS VIZSGÁLATÁNAK EREDMÉNYEI ÖSSZESSÉGÉBEN}

$\mathrm{Az}$ előző fejezetekben bemutatott modellek eredményei alapján a kereskedelembővülésre reális esély van az EU-ból érkező Aid for Trade-támogatások felhasználása során. Vizsgálatunk ugyan többnyire a szakirodalomban is fellelhető eredményekre vezetett, azonban az elemzés újszerüsége több ponton is tetten érhető:

- Az általunk megismert széles körü szakirodalom az elemzések során nem határozza meg a donort, az Aid for Trade hatásait az összes támogatás függvényében vizsgálja 
(kivétel ez alól Bearce és szerzőtársai (2010) munkája, ami az Egyesült Államok donortevékenységét elemzi).

- Az Európai Unióból származó Aid for Trade támogatások lehetséges hatásai egyelőre nincsenek a kutatók figyelmének középpontjában, így teljesen új elemzést végeztünk el.

- Bár a nemzetközi szakirodalomban többnyire csak az egyes részterületek lehetséges hatásaival foglalkoznak, a kevesebb háttérismeret miatt az EU-s Aid for Trade támogatásokat összességében is elemeztük.

- Az EU-s Aid for Trade támogatások összesített, illetve részterületeinek támogatása lehetőséget biztosít annak megállapítására, hogy az AfT mely részterülete(i) a meghatározó(ak) az EU és a fogadó ország közötti kereskedelem bővülésében.

- A részcsoportok vizsgálatával képet nyerhettünk arról, hogy az EU fejlesztési támogatásai valóban preferálják-e az ACP-országokat, illetve hogy ezek az országok hogyan tudják felhasználni ezeket a támogatásokat kereskedelmük bővítésére.

Az empirikus vizsgálat eredményei alapján egyértelmüen elfogadható, hogy az Európai Unióból származó Aid for Trade szignifikáns hatással bír a fogadó országok és az EU közötti kereskedelemre, mindez pedig megteremti a lehetőséget a fejlődő országok és az EU közötti kereskedelem bővülésére, így az EU-s fejlesztési politika hatékonyabbá válására, mindezzel pedig a 3. hipotézisünk megerősítést nyert. Viszont három tényezőt figyelembe kell venni:

- Egyrészt, a teljes kereskedelmet vettük alapul, így a kereskedelembővülés nem kizárólag a fejlődő országok exportnövekedését jelentheti, hanem az import bővülését is, ami hosszú távon komoly egyensúlytalanságot okozhat az országokban.

- Másrészt, elemzésünk nem terjedt ki az exportszerkezet vizsgálatára, így a bővülő kereskedelem nem feltétlenül párosul diverzifikáltabb exportszerkezettel.

- Harmadrészt, az Európai Unióból érkező AfT-támogatások hatásai alapvetően hasonlóságot mutatnak Cali és te Velde (2011) általános, nem donorfüggő elemzéséhez. Ahogy azt már a dolgozat 3.3.3. fejezetében ismertettük, a szerzők azt állapították meg, hogy az Aid for Trade területei közül a gazdasági infrastruktúra fejlesztésére fordított támogatások bővítik a fogadó ország exportját. Vizsgálatunk során az Európai Unió mint Aid for Trade-donor esetében hasonló megállapításra jutottunk: a gazdasági infrastruktúrára érkező támogatások szignifikáns tényező volt. 
Ugyan a szerzők azt is állítják, hogy a termelő kapacitás kiépítése egyáltalán nem játszik szerepet az export bővülésében, empirikus elemzésünk során ennek ellenkezőjét találtuk. Viszont a modell robusztusságának vizsgálata során kiderült, hogy ez esetben fenntartásokkal kell kezelni az eredményeket.

Bizonyossággal állítható viszont, hogy az Európai Unióból a gazdasági infrastruktúrára érkező támogatások az Aid for Trade tevékenység hatásainak elsődleges meghatározói. Bár Helble és szerzőtársai (2009) elemzésük során a kereskedelempolitika területére érkező támogatásokat szignifikánsnak találta, illetve több országtanulmány is található az EC (2008a) kiadványában, ami szintén a kereskedelempolitika fejlesztését emeli ki, az EU-ból érkező ilyen jellegü pénzügyi forrás esetében mégsem mondható az, hogy az EU és a fogadó országok közötti kereskedelmet bővítené.

Elemzésünk során az is bebizonyosodott - annak ellenére, hogy a korábbi klaszterelemzés mást sugallt -, hogy az ACP-országok kiemelt helyet foglalnak el az EU kereskedelmében, hiszen minden esetben szignifikánsan magasabb volt az ACP-országok kereskedelme az EU-val, mint a nem ACP-országoké. Ez persze nem kizárólag az ACPországok exportbővülését jelenti, hanem az EU-ból származó importjuk növekedését is magában foglalja. Ennek lehet pozitív és negatív oldala: egyrészt az EU-ból származó import révén fejlettebb technológiához juthatnak, másrészt viszont a megnövekedett import következtében a külkereskedelmi mérlegük romolhat, ami további fizetési nehézséget idézhet elő. Így szem előtt kell tartani azt, hogy az Európai Unió is nyertese lehet annak, hogy Aid for Trade-támogatást biztosít ezen országok számára (ahogyan erre már a Gazdasági Partnerségi Megállapodások tárgyalása során már kitértünk).

Mindezzel párhuzamosan a legkevésbé fejlett országok helyzete nem kedvező. Bár ezen országok mindenféle kereskedelempolitikai akadály nélkül juthatnak az EU piacaira; bár az Aid for Trade kiemelt céljai között a legkevésbé fejlett országok kereskedelembővítése áll; ugyan a 2005-ös európai fejlesztéspolitikai konszenzus kiemelt területei ezek az országok, az EU ezen országokkal való kereskedelmet nem tekinti elsődlegesnek. Az eredmények alapján az Európai Unió a relatíve magasabb jövedelmi helyzettel és gazdasági háttérrel bíró országokat tekinti föbb partnernek a fejlődő országok közül. Ez az eredmény pedig a Bearce és szerzőtársai (2010) által kapott eredményekkel ellentétes, hiszen elemzésük során az USA szegényebb országokban jelentősebb eredményt tudott elérni, ezekben az országokban a kereskedelemgeneráló hatás nagyobb lehet. Az EU esetében viszont a nem 
ACP-országok kedvezőbb helyzete és a legkevésbé fejlett országok negatív együtthatói miatt ez nem igazolható.

A részsokaságok elemzése során az ACP- és a nem ACP-országokat különítettük el. A nem ACP-országok szignifikánsan magasabb AfT-támogatásban részesülnek, és az egyes részterületekre érkező támogatások is szignifikánsan magasabbak, mint az ACP-országokban. Talán ennek is betudható, hogy a nem a legnagyobb preferenciában részesülő országok a támogatások kereskedelembővítő hatásában is jobb helyzetben vannak, mint az ACPországok. Mindezek alapján az ACP-országok ugyan még jelentős kapcsolatban vannak az Európai Unióval, mégis a nem ACP-országok azok, amelyek többet nyernek az EUval való - fejlesztési és kereskedelmi - kapcsolatokból, ha azok nem legkevésbé fejlett országok. Mindezt áttekintve pedig a 4. hipotézisben megfogalmazott állítást cáfolnunk kell.

Összességében és a Loméi Egyezmények sikertelensége ellenére az Európai Unió napjainkban is kiemelten kezeli a nemzetközi kereskedelem lehetséges pozitív hatásait a gazdasági növekedésre és fejlődésre vonatkozóan. Ugyan a keleti bővítések miatt a fejlesztéspolitikai fókusza átalakult, hivatalosan még mindig az ACP-országokat tekintik az elsődleges kedvezményezettnek. Azonban a fókusz irányának megváltozása következtében a nem ACP-országok kedvezőbb helyzetben vannak az Aid for Trade programon keresztül érkező támogatásokat illetően: egyrészt szignifikánsan több támogatást kapnak az Európai Uniótól, másrészt pedig az AfT-támogatások nagyobb hatását tudtuk megállapítani az EU-val folytatott kereskedelmüket illetően. Az ACP-országok EU-függősége ugyanakkor megmaradt, és az ő esetükben is beszélhetünk az Aid for Trade pozitív kereskedelembővítő hatásairól. Azonban mindkét esetben jellemző az, hogy a gazdasági infrastruktúra területére érkező támogatásoknak van valós kereskedelembővítő hatása - annak ellenére, hogy az Európai Unió a kereskedelempolitika és szabályozás, illetve a kereskedelemfejlesztés területére érkező támogatások jótékony hatását emeli ki (lásd az országtanulmányokat az EC (2008a) tanulmányban), ennek a területnek nincs szignifikáns hatása az EU és a fogadó országok közötti kereskedelem alakulására. Mindezek alapján elmondható, hogy az Aid for Trade program hozzájárulhat a közösségi fejlesztési politika hatékonyabbá válásához, viszont az ACP-országok relatíve kedvezőtlen segély-felhasználási lehetőségeire több figyelmet kell fordítani. 
Az első négy hipotézis eredményei alapján kaphatunk választ az 5. hipotézis állítására: az EU fejlesztési céllal használt kereskedelempolitikai eszközei hozzájárulnak az ACP-országok gazdasági fejlődéséhez. A négy korábbi hipotézisünk közül kettőt elfogadhatunk, és kettőt elutasíthatunk. Ezzel nem válik bizonytalanná az 5. hipotézis értékelése, hiszen azok a hipotézisek, melyek megerősítést nyertek a dolgozatban, egyrészt az országok közötti különbségekre mutattak rá (2. hipotézis), másrészt pedig az Aid for Trade EU-s fejlesztési politikába való illeszkedését erősítették meg (3. hipotézis). A másik kettő foglalkozik kifejezetten a gazdasági fejlődés eredményeivel és lehetőségeivel: ezek szerint a Loméi Egyezmények nem járultak hozzá ahhoz, hogy az ACP-országok relatív helyzete jelentős mértékben megváltozzon a vizsgált mutatók alapján (1. hipotézis), valamint az AfT sem elsősorban az ACP-országok megsegítésére irányul, és a kereskedelemgeneráló hatás is a csoportbon kívüli országokban jelentősebb. Ebből kifolyólag az 5. hipotézist is el kell vetnünk, hiszen összességében az EU fejlesztési céllal használt kereskedelempolitikai eszközei nem járultak hozzá az ACP-országok jelentős gazdasági fejlődéséhez, viszont az Aid for Trade ezt a folyamatot pozitívan befolyásolhatja. 


\section{6. ÖSSZEFOGLALÁS, KÖVETKEZTETÉSEK}

Jelen értekezés célja annak vizsgálata volt, hogy az Európai Unió milyen eredményeket tudott elérni nemzetközi fejlesztési politikájának kereskedelempolitikai eszközeivel az afrikai, karibi és csendes-óceáni (ACP-) országok gazdasági fejlődésének előmozdítása érdekében. Az elmúlt évtizedekben az importhelyettesítő, illetve exportösztönző stratégiákban már napvilágot láttak a nemzetközi kereskedelem adta, illetve az attól való elzárkózási lehetőségek mint fejlesztési eszközök. Az 1980-as évek óta az exportösztönzés mint neoklasszikus felfogás játssza a legnagyobb szerepet. Ezt mutatja az is, hogy a nemzetközi szervezetek nagy része, melyek a fejlődő országok fejlesztési kérdéseivel is foglalkoznak, ma már a nemzetközi kereskedelemben való részvételt is elfogadják a gazdasági fejlődés elérésében. Így napjainkban nemcsak egy-egy szereplő, egy-egy donor gondolja úgy, hogy a nemzetközi munkamegosztásban részt kell venni, hanem a jelentős befolyással bíró nemzetközi szervezetek is, és a Trade and Development Index komplex indikátor alapján az egész folyamatot számszerüsíteni is igyekeznek. Ennek következtében egyértelműen mondhatjuk, hogy a nemzetközi kereskedelem adta lehetőségek vizsgálata kiemelten fontos, és ez adta a jelen értekezésben bemutatott kutatás alapját. Kutatásunkat indokolta az is, hogy az Európai Unió nemzetközi fejlesztési politikája, különösen a hatékonyságvizsgálata a - hazai és nemzetközi - kutatások hátterébe szorul.

A felvetett kérdés megválaszolása érdekében empirikus úton vizsgáltuk meg az ACPországok és az EU által kötött Loméi Egyezmények lehetséges hatásait, mellyel célunk az EU tevékenységének múltbeli eredményeinek feltárása volt. Emellett a fejlesztési politika lehetséges jövőbeli irányvonalát szem előtt tartva az Európai Unióból származó, a fejlődő országokba eljuttatott Aid for Trade-támogatások eredményeit elemeztük szintén empirikus úton.

A dolgozat a téma megközelítése alapján két nagyobb egységre bontható. Az első egységben a pontos elemzés és az EU tevékenységére vonatkozó vizsgálat megalapozása érdekében a szükséges fogalmi keretet határoztuk meg, beleértve a fejlődő országok körének és az elmaradottságukhoz vezető tényezök meghatározását, valamint a nemzetközi fejlesztési együttmüködés kapcsán felmerült (általános) problémákat is. Emellett áttekintettük a kereskedelem, a nyitottság és a gazdasági növekedés kapcsán felmerült nem egyértelmü eredményeket, melyek az empirikus vizsgálatok módszertani hátterét befolyásolták. 
A dolgozat második részében az Európai Unió fejlesztéspoltikai tevékenységét részleteztük, melynek elemzése két időszak mentén történt: a fejlesztéspolitika részeként kezelt kereskedelempolitika irányvonalainak változása alapján az ezredforduló előtti és utáni periódust külön kezeltük. Az ezredforduló előtti időszakban a viszonosság nélküli kedvezmények jelentették az EU és az ACP-országok közötti kapcsolat kulcsát, így erre az időszakra vonatkozóan a Loméi Egyezmények hatásainak elemezése állt a középpontban, melyhez a többváltozós statisztikai módszerek közül (a főkomponens-analízissel kiegészített) klaszterelemzést alkalmaztuk. A második időszakot illetően az Aid for Trade lehetséges hatásainak elemzésére fókuszáltunk, hiszen a 2005-ben útjára indult program célja a fejlődő országok exportjának bővítése, valamint a kölcsönösségen alapuló Gazdasági Partnerségek Megállapodások végrehajtásának támogatása. Az Aid for Trade elemzése az ún. gravitációs modell alapján történt.

Jelen kutatás és értekezés jelentősége az alábbi tényezőkben rejlik. Az Európai Unió ma a világ legnagyobb donorszervezetének minősül, ennek ellenére fejlesztési politikájának mélyebb statisztikai vizsgálata háttérbe szorul. Ugyan a nemzetközi kereskedelem kapcsán számos empirikus tanulmány született, az Európai Unió által biztosított kereskedelmi kedvezmények vizsgálata kevesebb kutatás témája volt. Ezek azonban a hatásvizsgálatot nem fejlesztéspolitikai, hanem kereskedelmi vetületben tették. A Loméi Egyezmények lehetséges eredményeinek (statisztikai) vizsgálata is többnyire csak a kereskedelmi hatásokat tartalmazta, holott az egyezmények számos egyéb olyan beavatkozást tartalmaztak, amelyek a gazdaság más területeire és így a gazdasági fejlődésre is hatással lehettek. A nemzetközi kereskedelem szerepének felértékelődése ellenére az EU tevékenységének eredményességére nem térnek ki, holott már évtizedek óta biztosít különböző mértékü kereskedelmi preferenciákat a fejlődő országok többségének.

Emellett az Aid for Trade elindulása óta sem hazai, sem nemzetközi szinten nem foglalkoztak az Európai Unió e kezdeményezés megvalósításában betöltött szerepével. Korábban nem történt elemzés arra vonatkozóan, hogy az Aid for Trade egyáltalán beleillik-e az EU fejlesztési politikájába, foglalkozik-e a Közösség ezzel a kezdeményezéssel, milyen tervei vannak, és az eddigi eredmények alapján milyen hatásai vannak az EU-s Aid for Trade támogatásoknak a fejlődő országokkal folytatott kereskedelemre. Ebből következően a kereskedelempolitikai eszközök hatásáról átfogó elemzést adtunk az Európai Unió fejlesztési tevékenységének vonatkozásában: egyrészt a Közösség korábbi akcióinak eredményeit 
tartalmazza, azok hiányosságára is kitér, valamint bemutatja, hogy a korábbi hiányosságokat miként lehet javítani, és milyen eredményei lehetnek.

Továbbá, nem feledkezhetünk meg arról, hogy Magyarország is az EU tagja, ezzel a kutatás eredményei fontosak lehetnek hazánk számára is. Ugyanis EU-csatlakozásunk nyomán amellett, hogy saját fejlesztési politikánkat alakítjuk ki, alkalmazkodnunk is kell az EU által képviselt fejlesztési sajátosságokhoz, a pénzügyi (fejlesztési) forrásokhoz is hozzájárulunk. Ebből kifolyólag fontos, hogy tisztában legyünk azzal, hogy „,mibe vágtuk a fejszénket”, és megismerjük az Európai Unió tevékenységének hátterét, mozgatórugóit, az EU és az egyes tagországok érdekeit. Ez lehetővé teszi azt, hogy Magyarország - a maga szerény módján adott lehetőségeivel - alkalmazkodni tudjon az európai fejlesztési politikához és részt vegyen abban.

Az Európai Unió fejlesztési politikájában kiemelt figyelmet fordít a kereskedelempolitikai eszközöknek már az 1970-es évek közepe óta, és fejlesztési politikájának eszközrendszerében a pénzügyi támogatások mellett a kereskedelempolitikai lehetőségek is megjelennek. Ennek következtében lehetőség nyílott az EU tevékenységének hosszú távon történő vizsgálatára. Azonban éles váltás található az EU-ban az ACPországokat érintő kereskedelmi preferenciákban: míg az ezredforduló elött a viszonosság nélküli kedvezmények játszották a legnagyobb szerepet, addig az ezredforduló óta a kölcsönösség alapján kell tevékenykednie. Az ezredforduló után újabb kihívást jelentett az európai fejlesztési politikára a 2004-es és a 2007-es bővítés. Azonban ezek elsősorban a stratégiai fókusz irányát befolyásolták, nem pedig a fejlesztési támogatások összegeit.

A következőkben a dolgozat célja, a megfogalmazott hipotézisek és a kutatás eredményei alapján meghatározott öt tézist ismertetjük.

1. tézis: Az ACP-országok, de különösen az afrikai ACP-országok relatív helyzete a Loméi Egyezményekhez köthető gazdasági teljesítményük alapján nem kedvezőbb a Lomé-rendszert követő időszakban a többi mintabeli országhoz képest.

Az ezredforduló előtti időszakban az Európai Unió a Loméi Egyezményekkel mély kapcsolatot alakított ki az ACP-országokkal. Az egyezmények 25 éven keresztül biztosítottak a kereskedelmi kedvezményeken túl egyéb gazdasági preferenciákat (mezőgazdasági fejlesztés, gazdaságstabilizációs segélyek, külföldi tőke, modernizálás). A hosszú távon fennálló kedvezmények miatt az egyezmények hatásainak statisztikai úton történő vizsgálatát alkalmasnak tartottuk, ahol az ACP-országok relatív helyzetének változását vizsgáltuk a 
mintabeli országokhoz képest. A főkomponens-analízisre és klaszterelemzésre épülő többváltozós elemzés eredményei szerint a bevont 79 fejlődő ország mindkét időszakban öt klaszterbe rendezhető. A Loméi Egyezményeket megelőző időszakban az alábbi csoportok alakíthatók ki: elmaradott és zárkózott országok; EU-függő de elmaradott országok; relative fejlett de zárt országok; relative fejlett, EU-érdekeltségü országok; önálló, fejlett és nyitott országok csoportja. A később ACP-csoport tagjaivá váló országok zöme (81 százalék) a két legfejletlenebb csoportba került (az afrikai országok körében ez az arány 87 százalék). A két csoport között annyi a különbség, hogy az egyik csoport már ebben az időszakban is szorosabb kapcsolatot ápolt az EU-val.

Az egyezményeket követő időszak már a Loméi Egyezmények adta lehetőségek kihasználását is tartalmazza. Ebben az időszakban is öt klaszterbe rendezhetők a bevont országok a vizsgált indikátorok alapján: EU-függő de elmaradott országok elmaradott külgazdasági teljesitménnyel; EU-függö, elmaradott országok; független, relative fejlett országok; EU-érdekeltségü, relative fejlett, nyitott országok; fejlett és nyitott országok EUérdekeltséggel. Megállapítottuk, hogy az ACP-országok több mint 62 százaléka továbbra is a két, legkedvezőtlenebb gazdasági mutatókkal rendelkező csoportba került (és ezek 85 százaléka Afrikában található). Továbbá, az ezen klaszterekben található országok 79 százaléka már az első Loméi Egyezményt is aláírta, azaz ezek az államok 25 éven keresztül élvezhették a kedvezményeket.

A két időszak eredményeit összevetve állítjuk, hogy a Loméi Egyezményeket megelőző és követő időszak figyelembe vételével a vizsgálatban szereplő országok közül 54 tudott egyértelműen változtatni a mintában elfoglalt relatív pozícióján, ezek közül 36 ország javított a helyzetén, 18 ország pedig rontott a relatív pozícióján - ez utóbbiak 89 százaléka ACP-ország. Az ACP-országok egynegyede került magasabb fejlettségi szintet jelölő klaszterbe a második időszakban az előző időszakhoz képest, míg háromnegyedük esetében kedvezőtlen változás (stagnálás vagy romlás) történt. A javulást mutató országok között nyolc olyan ACP-ország található, melyek legalább „két klaszternyi” fejlődést tudnak felmutatni. Összességében az ACP-csoporton kívüli országok tudtak javítani relatív helyzetükön.

Annak ellenére, hogy az ACP-országok Lomé-rendszert megelőző és követő gazdasági teljesítménye között szignifikáns különbség található (néhol pozitív változás, bár az EU szerepének csökkenése is látható), ezek nem tekinthetők olyan mértékünek, hogy relatív pozíciójuk a többi mintabeli országhoz képest megváltozzon. Ebben szerepet játszhatott az is, ezen országok többségében (azaz a két legfejletlenebb klaszterben) az intézményi háttér 
kedvezőtlenebb, mint a fejlettebb klaszterben lévőké (ugyanakkor az ok-okozati összefüggéseket nem vizsgáltuk!). Összességében tehát az ACP-országok relatív helyzete a Loméi Egyezmények adta lehetőségek ellenére nem javult a mintában szereplő többi országhoz képest.

2. tézis: Az ACP-országok több csoportra bonthatók: a Loméi Egyezményekhez köthető gazdasági teljesítményük alapján az afrikai ACP-országok a leggyengébben teljesítő országok, míg az EU-tól távolabb elhelyezkedő országok kedvezőbb eredménnyel rendelkeznek.

A Loméi Egyezmények előtti időszakban a leendő ACP-országok két csoportra bonhatóak: a két legfejletlenebb klaszter tagjai lettek. A Lomé-rendszert követően sincs változás: az ACP-csoportba tartozó országok 81 százaléka a két legfejletlenebb klaszterbe került. Jellemzőjük, hogy alacsony minőségü intézményi háttérrel rendelkeznek. A Loméi Egyezményeket követő időszakban a vizsgálatban szereplő 48 ACP-ország 4 klaszterbe sorolható, és három klaszterben egyértelmüen dominálnak (a tagok több mint 60 százaléka ACP-ország). Viszont az összes ACP-ország fele (24) egy csoportba került, melyek mindegyike afrikai fejlődő ország. A másik 50 százalék a maradék három klaszter között nagyjából 1/3-1/3 arányban oszlik meg. Egyértelmüen az afrikai ACP-országok teljesítenek a legrosszabbul: a 39 afrikai országból 29 (azaz 74 százalékuk) került a két legfejletlenebb klaszter valamelyikébe az egyezmények utáni időszakban. Összességében az egyéb (az EU-tól távolabb eső, viszont földrajzilag az USA-hoz közelebb elhelyezkedő) régiók - az elemzésbe bevont indikátorok alapján - jobban teljesítettek, viszont közöttük nem lehet különbséget tenni, nem lehet régió szerint meghatározni, hogy mely országok teljesítettek jobban vagy rosszabbul. Ennek ellenére - de a fentiek alapján - egyértelmüen vannak jobban és rosszabban teljesítő országok, és ezeket több, homogén csoportra tudjuk osztani.

3. tézis: Az Aid for Trade mint a nemzetközi kereskedelemben való aktív részvétel fejlesztését célzó pénzügyi támogatás az $E \mathrm{U}$-s fejlesztési politika pénzügyi és kereskedelempolitikai eszközeit kapcsolja össze. Az AfT-támogatások azokat a területeket fedik le, amelyek korábban a Loméi Egyezmények alacsony hatékonyságát eredményezték, így az AfT illeszkedik az EU fejlesztési politikájába. 
Az ezredforduló óta az EU nemzetközi nyomás hatására kölcsönösségen alapuló kedvezményeket biztosít a fejlődő országok számára, viszont a Loméi Egyezmények kudarca alapján nem bízhatunk abban, hogy ezek sokkal több eredményt fognak elérni. Azonban a Loméi Egyezmények alacsony hatékonyságához vezető tényezők közül több is kezelhető az Aid for Trade programon keresztül érkező támogatásokkal: az infrastruktúra, a fizikai és a humán tőke, a pénzügyi szektor fejlesztésére, valamint a beruházások és megtakarítások növelésére az Aid for Trade részterületei (kereskedelemmel összefüggő infrastruktúra, termelési kapacitás fejlesztése, kereskedelempolitika és fejlesztés) biztosítanak pénzügyi támogatást.

Az Aid for Trade ilyen mértékü illeszkedése kiemelten fontos a tekintetben, hogy a Gazdasági Partnerségi Megállapodások végrehajtásának eszközének tekintik az AfTtámogatásokat (illetve egyelőre még a tárgyalások lezárásának eszköze). Ezek alapján, valamint az EU fejlesztéspolitikai eszközrendszerét áttekintve állíthatjuk, hogy az Aid for Trade teljes mértékig beilleszthető az Európai Unió fejlesztési tevékenységébe. Az AfT fontos szerepe megjelenik abban, hogy az EU külön AfT-stratégiát dolgozott ki és fogadott el 2007-ben, amelyben továbbra is az ACP-országok kiemelt szerepét hangsúlyozzák.

Az AfT fejlesztéspolitikai integrálódása abban is tetten érhető, hogy az Európai Unióból érkező Aid for Trade támogatások kereskedelemre gyakorolt hatásai egyértelmüek. A gravitációs modell eredményei szerint az Aid for Trade keretében nyújtott pénzügyi források pozitívan járulnak hozzá az EU és a fogadó országok kereskedelmének alakulására. Az egyes Aid for Trade-területek azonban eltérő hatással bírnak: egyértelműen a gazdasági (kereskedelmi) infrastruktúra fejlesztésére irányuló támogatásoknak van szignifikáns hatása. Ennek következtében az EU-ból érkező AfT-támogatások kereskedelembővítő hatása a gazdasági infrastruktúra területének fejlesztése révén következik be. Viszont ez nem kizárólag a fogadó országok számára jelent gazdasági előnyt, hanem a donorok számára is.

4. tézis: Az ACP-csoporton kívüli országok átlagosan több Aid for Tradetámogatást kapnak az Európai Unióból. Ugyan mind az ACP-, mind a nem ACPországokban kereskedelembővítő hatása van a gazdasági infrastruktúra fejlesztését célzó Aid for Trade-támogatásoknak, e hatás nagyobb az ACP-blokkon kívüli államokban. 
Az ACP-csoporton kívüli országok számára átlagosan több Aid for Trade-támogatást folyósít az Európai Unió, mint az ACP-országokba - annak ellenére, hogy ezen országcsoport mindig is kiemelt figyelemben részesült, és az Aid for Trade stratégia is az ő jelentőségüket hangsúlyozta. Összességében a nem ACP-országokban az Aid for Trade és a gazdasági infrastruktúra területére érkező támogatások nagyobb hatással vannak a kereskedelem bővülésére, mint az ACP-országokban. Hangsúlyozandó azonban, hogy az ACP-országokban is kereskedelemgeneráló hatása van az Aid for Trade-támogatásoknak! Az ACP-csoporton kívüli országokban a támogatás 1 százalékos növelése 0,079 százalékos kereskedelembővülést eredményez, míg az ACP-országok körében ez 0,043 százalék. Ezek alapján az ACP-csoporton kívüli országok kedvezőbb helyzetben vannak, mint maguk az ACP-országok. Ennek oka az ACP-országok segélyek fogadására alkalmatlan, illetve kevésbé hatékony intézményi háttér lehet, illetve az, hogy ezen csoportban sokkal több alacsony jövedelmü ország található, mint a másik blokkban.

A teljes minta alapján végzett vizsgálat eredményei alapján az ACP-országokban a termelő kapacitás fejlesztését célzó támogatásoknak is szignifikáns hatása van az EU és a recipiens országok közötti kereskedelem bővülésére: e támogatások 1 százalékos növelése 0,141 százalékos kereskedelemnövekedést eredményez a partnerországok között. Azonban a modell robusztusságának ellenőrzése során - a kiugró értékek kiszürésével - ez a terület mind a teljes minta, mind pedig az ACP-országok körében inszignifikánssá vált. Ennek következtében a termelő kapacitás területét illetően óvatosan kell fogalmazni.

Összességében a két csoport közötti intézményi fejlettségbeli különbség meglátszódik. Azonban fontos tény az is, hogy a legkevésbé fejlett országok helyzete kedvezőtlen: ha az ország ebbe a csoportba tartozik, akkor az EU-val lényegesen kevesebb kereskedelmet folytat, mint a fejlettebb társai. Annak ellenére van ez így, hogy az EU fejlesztési politikájában a legkevésbé fejlett országok megsegítését, piacra jutásának biztosítását is hangsúlyozza, illetve magának az Aid for Trade-nek is a céljai között szerepel, hogy elsődlegesen a legkevésbé fejlett országok kereskedelmi kapacitásainak fejlesztését kellene támogatni.

5. tézis: Az Európai Unió fejlesztési céllal használt kereskedelempolitikai eszközei nem tekinthetők eredményesnek az ACP-országok gazdasági fejlődésének előmozdításában, viszont az Aid for Trade hozzájárulhat a hatékonyság javulásához. 
A dolgozatban bemutatott vizsgálati módszerek alapján az Európai Unió fejlesztési tevékenysége a kereskedelempolitikai eszközök adta lehetőségekkel nem tekinthető kiemelkedőnek, különösen az afrikai ACP-országok vannak jelentősen lemaradva. A Loméi Egyezmények a tartalmuk alapján meghatározható hatásmechanizmus alapján várt eredményekkel ellentétben nem tekinthetőek eredményesnek: az ACP-, de különösen az afrikai országok más olyan fejlődő országokhoz képest sokkal gyengébb gazdasági teljesítménnyel rendelkeznek, annak ellenére, hogy az EU elsődleges fejlesztési területeinek minősülnek. Az Aid for Trade is a magasabb jövedelmi szintü országoknak kedvez. Ezek alapján a dolgozat végkövetkeztése az, hogy a szabad piacra lépés a kiegészítő beavatkozási területekkel (ipari együttmüködés, technológiai fejlesztés, FDI szabad áramlása) együtt sem lehet megoldás a gazdasági fejlődés elérésében az ACP-országok esetében. Az elemzés során - összességében - egyértelműen kiderült az, hogy a fejlettebb intézményi háttérrel rendelkező országok jobb gazdasági teljesítménnyel is rendelkeznek.

Mivel az EU a kereskedelempolitikát a jövőben is fejlesztési tevékenységének eszközeként használja, így nem hagyható figyelmen kívül, hogy a jövőben milyen eredmények várhatóak. Az elmúlt 30 év tapasztalatai kedvezőtlenek, viszont az Aid for Trade adta lehetőségek kedvezően befolyásolhatják az EU törekvéseit és az ACP-országok fejlődését. Ugyanakkor nem szabad figyelmen kívül hagyni azt a tényt sem, hogy ezek a támogatások nem csak a fogadó országok számára jelentenek hasznot, hanem magának az EU-nak is. Összességében mindenképpen nyomon kell követni, hogy a Cotonou-i Egyezmény és az ennek keretében megkötött Gazdasági Partnerségi Megállapodások milyen eredményre vezetnek majd az Aid for Trade adta lehetőségekkel együtt.

A kutatás azonban nem tekinthető lezártnak, hiszen további kérdések merültek fel, melyek elemzésére jelen dolgozat keretei között már nem tudtunk kitérni. Egyrészt, az EU keleti bővítése kapcsán felmerült fókusz-eltolódás elemzése teret ad a további kutatásoknak: valóban háttérbe szorulnak az ACP-országok az új igények miatt, vagy sikerül újra a középpontba kerülni? Ennek elemzésére a dolgozat 5. fejezetében bemutatott módszer megfelelő alapot jelenthet: az EU-15 és az új tagállamok fejlődő országokkal folytatott kereskedelmét célszerü lenne egymástól elválasztani, és a két csoport vonatkozásában megvizsgálni, hogy az EU-15 által folyósított támogatások befolyásolják-e a fogadó országok és az új tagországok közötti kereskedelem alakulását. Mivel a Loméi Egyezmények eredményei kapcsán az intézményi háttér jelentős hatással bír, így az intézmények szerepét is 
mélyebben szükséges elemezni. Másrészt, az EU-15 országainak tevékenységet is érdemes lenne részenként, kisebb csoportokban végezni. Ugyan a dolgozatban az Aid for Trade elemzését az EU-15 teljesítménye alapján összevontan elemeztük, érdemes lehet ezt a donorcsoportot kisebb, homogénebb csoportokra bontani. A homogén csoportok meghatározása érdekében viszont az egyes tagállamok fejlesztési politikájának mélyebb ismerete elengedhetetlen. Harmadrészt, további kutatási terület lehet a Cotonou-i Egyezmény mélyebb vizsgálata, a gazdasági partnerségi megállapodások eredményeinek elemzése is. Mivel Kína egyre jelentősebb szereplő Afrikában, így ezt az elemzést egy Kína-EU összehasonlítássá is ki lehetne bővíteni, annak feltárása érdekében, hogy az európai és a kínai érdekek, eredmények között milyen különbségek figyelhetők meg. 


\section{FELHASZNÁLT IRODALOM}

Abass, A. (2004): The Cotonou Trade Régime and WTO Law. European Law Journal, 4, 439-462. o.

Abbott, P. - Bentzen, J. - Tarp, F. (2009): Trade and development: lessons from Vietnam's past trade agreements. World Development, 2, 341-353. o.

Abegaz, B. (2005): Multilateral development aid for Africa. Economic Systems, 4, 433-454. o.

Acemoglu, D. - Johnson, S. - Robinson, S. (2001): The colonial origins of comparative development: An empirical investigation. American Economic Review, 5, 1369-1401. o.

Acemoglu, D. (2010): Theory, general equilibrium and political economy in development economics. Working Paper, 10-6, Massachusetts Institute of Technology, Cambridge.

ACPSec (2011): The ACP Group. Letölthetö: http://www.acpsec.org/en/about_us.htm (Letöltve: 2011. október 30.)

Africano, A. P. - Magelhães, M. (2005): FDI and trade in Portugal: a gravity analysis. FEP Working Papers, 174, Faculdade de Economia de Porto.

Agbeyegbe, T. D. - Stotsky, J. - WoldeMariam, A. (2006): Trade liberalization, exchange rates changes, and tax revenue in Sub-Saharan Africa. Journal of Asian Economics, 2, 261-284. o.

Aiello, F. - Cardamone, P. (2010): Analysing the impact of the EBA initiative using a gravity model. Working Paper, 10/7, University of Calabria.

Alesina, A. - Weder, B. (2002): Do corrupt governments receive less foreign aid? American Economic Review, 4, 1126-1137. o.

Al-Khaldi, M. D. (2008): Impact of foreign aid on economic development in Jordan. Journal of Social Sciences, 1, 16-20. o.

Allen, F. - Giovannetti, G. (2011): The effects of the financial crisis on Sub-Saharan Africa. Review of Development Finance, 1, 1-27. o.

Anania, G. (2010): EU Economic Partnership Agreements and WTO negotiations. A quantitative assessment of trade preference granting and erosion in the banana market. Food Policy, 2, 140-153. o.

Anderson, J. (2001): Gravity with gravitas: a solution to the border buzzle. NBER Working Paper, 8079, National Bureau of Economic Research, Cambridge.

Andriamananjara, S. - Balistreri, E. J. - Ross, M. T. (2006): State-level equity and the demise of the Agreement on Textiles and Clothing. North American Journal of Economics and Finance, 1, 17-33. o.

Ang, J. (2009): Household saving behaviour in an extended life cycle model: A comparative study of China and India. Journal of Development Studies, 8, 1344-1359. o.

Angeles, L. - Neanidis, K. C. (2009): Aid effectiveness: the role of the local elite. Journal of Development Economics, 1, 120-134. o.

Arts, K. - Dickson, A. (2004): EU development cooperation: from model to symbol? In Arts, K. Dickson, A. (eds.): EU development cooperation: from model to symbol? Manchester University Press, Manchester, 1-16. o.

Babarinde, O. A. (1994): The Lomé Conventions and development. An empirical assessment. Aveburg Ashgate Publishing Limited, Aldershot, England.

Babarinde, O. - Faber, G. (2004): From Lomé to Cotonou: Business as usual? European Foreign Affairs Review, 9, 27-47. o. 
Balassa, B. (1985): Exports, policy choices, and economic growth in developing countries after the 1973 oil shock. Journal of Development Economics, 1, 23-35. o.

Balatoni A. - Törös Á. (2010): Gazdaságfejlesztési modellek empirikus klasszifikációja és a posztszocialista növekedés szük keresztmetszete. Külgazdaság, 5-6, 33-58. o.

Balázs P. (2002): Az Európai Unió külpolitikája és a magyar-EU kapcsolatok fejlödése. KJKKERSZÖV Jogi és Üzleti Kiadó Kft, Budapest.

Baldwin, R. E. (2003): Openness and growth: What's the empirical relationship? NBER Working Paper Series, 9578, National Bureau of Economic Research, Cambridge.

Baulch, B. (2006): Aid distribution and the MDGs. World Development, 6, 933-950. o.

Berthelemy, J-C. - Beuran, M. - Maurel, M. (2009): Aid and migration: Substitutes or complements? World Development, 10, 1589-1599. o.

Bhalla, A. S. - Qiu, S. (2004): The employement impact on China's WTO accession. RoutledgeCurzon, London.

Biró Sz. (2009): A földjelzálog-hitelezés intézményrendszere és alkalmazási lehetöségei a magyar mezögazdaságban. Doktori értekezés, Szent István Egyetem, Gödöllő.

Bearce, D. H. - Finkel, S. E. - Pérez-Linán, A. S. - Rodríguez-Zependa, J. - Surzhko, L. (2010): Has Aid for Trade increased recipient exports? The impact of US AfT allocations 1999-2008. Letölthetö: http://ssrn.com/abstract=1663325 (Letöltve: 2011 . március 12.)

Bjornskov, C. - Krivonos, E. (2001): From Lomé to Cotonou. The new EU-ACP Agreement. Working Papers, 14, Danish Institute of Agricultural and Fisheries Economics (SJFI).

Boros J. (2005): Magyarország nemzetközi fejlesztési stratégiája és összefüggései. In Gömbös E. (szerk.): A nemzetközi fejlesztési együttmüködés a XXI. században. Magyar ENSZ Társaság, HUNIDA Kht., Budapest, 21-27. o.

Borrmann, A. - Busse, M. (2007): The institutional challenge of the EU/ACP Economic Partnership Agreements. Development Policy Review, 4, 403-416. o.

Borrmann, A. - Busse, M. - De La Rocha, M. (2007): Consequences of Economic Partnership Agreements between East and Southern African countries and the EU for inter- and intraregional integration. International Economic Journal, 2, 233-253. o.

Boutros-Ghali, B. (1995): Fejlesztési program. Az ENSZ fötitkárának jelentése. Egyesült Nemzetek Szervezete, Magyar ENSZ Társaság, Budapest.

Boysen, O. - Matthews, A. (2009): The Economic Partnership Agreement between Uganda and the EU: trade and poverty impacts. IIIS Discussion Paper, 307, Institute for International Integration Studies.

Broad, R. - Cavanagh, J. (1999): The death of the Washington consensus? World Policy Journal, 3, 79-88. o.

Broad, R. (2004): The Washington Consensus meets the global backlash: Shifting debates and policies. Globalizations, 2, 129-154. o.

Bruton, H. J. (1968): Import substitution and productivity growth. Journal of Development Studies, 3, 306-326. o.

Bulir, A. - Hamann, A. J. (2008): Volatility of development aid: From the frying pan into the fire? World Development, 10, 2048-2066. o.

Burke, P. J. - Ahmadi-Esfahani, F. Z. (2006): Aid and growth: a study of South East Asia. Journal of Asian Economics, 2, 350-362. o.

Burnside, C. - Dollar, D. (2000): Aid, policies, and growth. American Economic Review, 4, 847868. o. 
Busse, M. - Grossman, H. (2007): The trade and fiscal impact of EU/ACP Economic Partnership Agreements on West African countries. Journal of Development Studies, 5, 787-811. o.

Cali, M. - te Velde, D. W. (2011): Does Aid for Trade really improve trade performance? World Development, 5, 725-740. o.

Carey, K. - Gupta, S. - Jacoby, U. (2007): Forging new trade links with Asia. Sub-Saharan Africa. International Monetary Fund, Washington, D. C.

Cashin, P. - McDermott, C. J. - Pattillo, C. (2004): Terms of trade shocks in Africa: are they short-lived or long-lived? Journal of Development Economics, 2, 727-744. o.

Chang, R. - Kaltani, L. - Loayza, N. V. (2009): Openness can be good for growth: the role of policy complementarities. Journal of Development Economics, 1, 33-49. o.

CEPII (2011): Distances. Letölthető: http://www.cepii.fr/anglaisgraph/bdd/distances.htm (Letöltve: 2011. július 13.)

Chen, A. (2010): Reducing China's regional disparities: Is there a growth cost? China Economic Review, 1, 2-13. o.

Chen, J-R. - Sapsford, D. (1997): Economic development and policy: Professor Sir Hans Singer's contributions to development economics. World Development, 11, 1853-1856. o.

Cipollina, M. - Salvatici, L. (2010): The trade impact of European Union agricultural preferences. Journal of Economic Policy Reform, 1, 87-106. o.

Cipollina, M. - Laborde, D. - Salvatici, L. (2010): Do preferential trade policies (actually) increase exports? A comparison between EU and USA trade policies. Virtual Proceedings, European Trade Study Group International Conference, 29 o. Letölthető: http://www.etsg.org/ETSG2010/papers/CipollinaLabordeSalvatici.pdf

Collier, P. (2008): The bottom billion: Why the poorest countries are failing and what can be done about it. Oxford University Press, Oxford.

Collier, P - Dollar, D. (2001): Can the world cut poverty in half? How policy reform and effective aid can meet international development goals. World Development, 11, 1787-1802. o.

Collier, P. - Dollar, D. (2002): Aid allocation and poverty reduction. European Economic Review, 8, 1475-1500. o.

Collier, P. - Guillaumont, P. - Guillaumont, S. - Gunning, J. W. (1997): The future of Lomé: Europe's role in African growth. The World Economy, 3, 285-305. o.

Combes, J-L. - Saadi-Sedik, T. (2006): How does trade openness influence budget deficits in developing countries? Journal of Development Studies, 8, 1401-1416. o.

Cosgrove, C. (1994): Has the Lomé Convention failed ACP trade? Journal of International Affairs, 1, 223-250. o.

Curran, L. - Nilsson, L. - Brew, D. (2008): The Economic Partnership Agreements: Rationale, Misperceptions and Non-trade Aspects. Development Policy Review, 5, 529-553. o.

Cypher, J. M. - Dietz, J. L. (2004): The process of economic development. Routledge, New York.

Csanádi M. - Lai, H. - Gyuris F. (2009): A világválság és hatása a rendszer átalakulására Kínában. Közgazdasági Szemle, 9, 814-834. o.

Csáki Gy. (2002): A nemzetközi gazdaságtan alapjai. Napvilág Kiadó, Budapest.

Dalgaard, C.J. - Hansen, H. - Tarp, F. (2004): On the empirics of foreign aid and growth. Economic Journal, 496, F191-F216. o.

Dalgaard, C-J. - Erickson, L. (2009): Reasonable expectations and the first Millennium Development Goal: How much can aid achieve? World Development, 7, 1170-1181. o. 
Daniels, P. L. (2005): Economic systems and the Buddhist world view: the $21^{\text {st }}$ century nexus. Journal of Socio-Economics, 2, 245-268. o.

Dauderstädt, M. (ed.) (2002): EU eastern enlargement and development cooperation. FriedrichEbert Stiftung, Bonn.

Deardorff, A. V. - Stern, R. M. (2009): Alternatives to the Doha Round. Journal of Policy Modeling, 4, 526-539. o.

Degnbol-Martinussen, J. and Engberg-Pedersen, P. (2005): Aid: understanding international development cooperation. Zed Books, London.

De Jong, E. - Bogmans, C. (2011): Does corruption discourage international trade? European Journal of Political Economy, 2, 385-398. o.

Deza, E. - Deza, M. M. (2006): Dictionary of distances. Elsevier, Amsterdam - Oxford.

Dezséri K. (2003): Az EU fejlesztéspolitikája a fejlődő országok megsegítésére. Tanulmány, MTA - Világgazdasági Kutatóintézet, Budapest.

Dobson, S. - Ramlogan, C. (2009): Is there an openness Kuznets curve? Kyklos, 2, 226-238. o.

Dodaro, S. (1991): Comparative advantage, trade and growth: Export-led growth revisited. World Development, 9, 1153-1165. o.

Dodzin, S. - Vamvakidis, A. (2004): Trade and industrialization in developing countries. Journal of Development Economics, 1, 319-328. o.

Dollar, D. - Kraay, A. (2003): Institutions, trade, and growth. Journal of Monetary Economics, 1, 133-162. o.

Doucouliagos, H. - Paldam, M. (2007): The Aid Effectiveness Literature: the Sad Results of 40 Years of Research. Economic Working Paper, 2005-15, University of Aarhus.

Dowling, M. - Cheang, C. T. (2000): Shifting comparative advantage in Asia: new tests of the „flying geese” model. Journal of Asian Economics, 11, 443-463. o.

Dreger, C. - Herzer, D. (2011): A further examination of the export-led growth hypothesis. Discussion Paper, 305, European University Viadrina Frankfurt.

Dusek T. (2003): A gravitációs modell és a gravitációs törvény összehasonlítása. Tér és Társadalom, 1, 41-58. o.

Dutt, A. K. - Ros, J. (szerk.) (2008): International Handbook of Development Economics. Edward Elgar, Cheltenham és Northampton.

Easterly, W. - Levine, R. (2003): Tropics, germs, and crops: how endowments influence economic development. Journal of Monetary Economics, 1, 3-39. o.

EC (1986): Third ACP-EEC Convention signed at Lomé on 8 December 1984. Official Journal, L 086., Luxembourg, 1-208. o.

EC (1991): Fourth ACP-EEC Convention signed at Lomé on 15 December 1989. Official Journal, L 229., Luxembourg, 1-220. o.

EC (1996): Green Paper on relations between the European Union and the ACP countries on the eve of the 21st century. Challenges and options for a new partnership. European Commission, Brussels.

EC (2000): Partnership agreement between the members of the African, Caribbean and Pacific Group of States of the one part, and the European Community and its Member States, of the other part, signed in Cotonou on 23 June 2000. Official Journal, L 317, Luxembourg, 3-287. o.

EC (2002): External and intra-European Union trade - Statistical Yearbook. Office for Official Publications of the European Communities, Luxembourg. 
EC (2005a): External relations. Press release, 8817/05 (Presse 112). Council of the European Union.

EC (2005b): Politikák fejlesztési célú koherenciája. A haladás felgyorsitása a millenniumi fejlesztési célok elérése felé. COM (2005) 134, Európai Bizottság, Brüsszel.

EC (2006a): Európai Unió - Az Európai Unióról szóló szerződés és az Európai Közösséget létrehozó szerződés egységes keretbe foglalt változata. Az Európai Unió Hivatalos Lapja, C $321 \mathrm{E}$.

EC (2006b): The European Consensus on Development. Official Journal of the European Union, C 46/1, 1-20. o.

EC (2007): Council Agrees EU Strategy on Aid for Trade Program. Council of the European Union, Brussels.

EC (2008a): Making Trade Work for Development. European Commission, Brussels.

EC (2008b): Financial Programming and Budget - Glossary. http://ec.europa.eu/budget/other_main/glossary_en.htm\#E, Letöltve: 2008. március 5.

EC (2008c): Az Európai Unióról szóló és az Európai Unió működéséről szóló szerződés egységes szerkezetbe foglalt változata. Hivatalos Lap, C 115, 1-388. o.

EC (2008d): Council Regulation (EC) No 732/2008 of 22 July 2008 applying a scheme of generalised tariff preferences for the period from 1 January 2009 to 31 December 2011 and amending Regulations (EC) No 552/97, (EC) No 1933/2006 and Commission Regulations (EC) No 1100/2006 and (EC) No 964/2007. Official Journal, L 211, 1-39. o.

EC (2008e): External and intra-European Union trade - Statistical Yearbook - Data 1958-2006. Office for Official Publications of the European Communities, Luxembourg.

EC (2009a): Council conclusions on supporting developing countries in coping with the crisis. Council of the European Union.

EC (2009b): Aid for Trade - Trade Factsheet. European Commission. http://trade.ec.europa.eu/doclib/docs/2008/october/tradoc_140837.pdf (Letöltve: 2011. augusztus 28.)

EC (2010): Aid for Trade Monitoring Report 2010. SEC(2010) 419 final, European Commission, Brussels.

EC (2011a): Development policies. http://ec.europa.eu/europeaid/what/developmentpolicies/index_en.htm (Letöltve: 2011. július 23.)

EC (2011b): Trade and regional integration. http://ec.europa.eu/europeaid/what/developmentpolicies/intervention-areas/trade/index_en.htm (Letöltve: 2011. július 23.)

EC (2011c): Euro-Mediterranean Partnership (EUROMED). Letölthetö: http://www.eeas.europa.eu/euromed/index_en.htm (Letöltve: 2011. október 30.)

EC (2011d): Commissioner Piebalgs calls for EU to maintain its leadership on official development aid as new figures reveal it spent a record 53,8 billion in 2010. Letölthetö: http://ec.europa.eu/europeaid/how/ensure-aid-effectiveness/documents/eu-aid-budget2010_en.pdf (Letöltve: 2011. november 23.)

EC-ACP (1975): The Georgetown Agreement on the organization of the African, Caribbean and Pacific group of $1975 . \quad$ Ltates, http://www.wipo.int/wipolex/en/regeco_treaties/text.jsp?doc_id=150499\&file_id=201070 (Letöltve: 2011. október 25.)

Edwards, S. (1996): Why are Latin America's savings rates so low? An international comparative analysis. Journal of Development Economics, 1, 5-44. o. 
Egedy G. (2007): Bevezetés a nemzetközi kapcsolatok elméletébe. HVG-ORAC Lap- és Könyvkiadó Kft., Budapest.

Ekholm, K. - Södersten, B. (2002): Growth and trade vs. Trade and growth. Small Business Economics, 19, 147-162. o.

El-Fallah, M. - El-Sallam, A. (2011): Estimation methods for multicollinearity problem combined with high leverage data points. Journal of Mathematics and Statistics, 2, 129-136. o.

Elliott, K. A. (2011): US trade policy: Don't leave the poor behind. CGD Notes, May, Center for Global Development.

Esu, B. B. - Awara, N. F. (2010): Export promotion and the global economic crisis. Experiences and lessons for Nigeria as a mono-product economy. Acta Oeconomia Pragensia, 4, 12-31. o.

Evenett, S. J. (2008): Aid for Trade and the „Missing Middle” of the WTO. Working Paper, 200825, University of St. Gallen.

Faber, G. - Orbie, J. (2008): The new trade and development agenda of the European Union. Perspectives on European Politics and Society, 2, 192-207. o.

Farkas $P$. (2005): A fejlödő országok főbb térségei és ezek sajátosságai. In Gömbös E. (szerk.): A nemzetközi fejlesztési együttmüködés a XXI. században. Magyar ENSZ Társaság, HUNIDA Kht., Budapest, 135-144. o.

Farrell, M. (2005): A Triumph of realism over idealism? Cooperation between the European Union and Africa. European Integration, 3, 263-283. o.

Ferkelt B. - Gáspár A. (2008): Konvergencia-vizsgálatok az Európai Unióban. EU Working Papers, 1, 35-44. o.

Filippini, C. - Molini, V. (2003): The determinants of East Asian trade flows: a gravity equation approach. Journal of Asian Economics, 5, 695-711. o.

Fontagne, L. - Mitaritonna, C. - Laborde, D. (2008): An impact study of the EU-ACP Economic Partnership Agreements (EPAs) in the six ACP regions. CEPII-CIREM, Paris.

Freedom House (2011): Freedom in the world comparative and historical data. Letölthetö: http://www.freedomhouse.org/template.cfm?page $=439$ (Letöltve: 2011. november 24.)

Freund, C. - Bolaky, B. (2008): Trade, regulations, and income. Journal of Development Economics, 2, 309-321. o.

Furuoka, F. (2005): Japan and the 'flying geese' pattern of East Asian integration. Eastasia.at, 1, 6 o.

Gamberoni, E. - Newfarmer, R. (2009): Aid for Trade - Matching Potential Demand and Supply. The World Bank.

Gathii, J. T. (2007): Approaches to accessing essential medicines and the TRIPS Agreement. In Yu, P. K. (ed.): Intellectual property and information wealth. Praeger Publishers, Westport, 393-413. o.

Gábor T. (2009): Kína árfolyam-politikája és a globális egyensúlytalanságok. Hitelintézeti Szemle, 2, 111-124. o.

Gács J. (2007): A gazdasági globalizáció számokban. A nyitottság alakulása az EU országaiban I. rész. Közgazdasági Szemle, 10, 876-902. o.

Gáspár A. - Udvari B. (2011): A Loméi Egyezmények felzárkózásra gyakorolt hatása. Statisztikai Szemle, 4, 420-447. o.

Ghosh, B. N. (2008): Development in development economics. In Ghosh, B. N. (ed.): Contemporary issues in development economics. Routledge, London and New York, 1-15. o. 
Gibb, R. (2006): The European Union's 'Everything But Arms' development initiative and sugar: Preferential access or continued protectionism? Applied Geography, 1, 1-17. o.

Gilpin, R. (2006): Global political economy: understanding the international economic order. Princeton University Press, Princeton, Oxford.

Glennie, J. (2011): The role of aid to middle-income countries: a contribution to evolving EU development policy. Working Paper, 331, Overseas Development Institute, London.

Goldin, I. - Reinert, K. A. (2007): Globalization for Development. World Bank and Palgrave Macmillan.

Gore, C. (2002): Globalization, the international poverty trap and chronic poverty in the least developed countries. Working Paper, No. 30, Chronic Poverty Research Centre.

Grabowski, R. (1994): Import substitution, export promotion, and the state in economic development. Journal of Developing Areas, 4, 535-554. o.

Granell, F. (2005): Can the fifth enlargement weaken the EU's development cooperation? Jean Monnet/Robert Schuman Paper Series, 24, Miami European Union Centre, Miami.

Grange, L. de - Troncoso, R. - Ibeas, A. - González, F. (2009): Gravity model estimation with proxy variables and the impact of endogeneity on transportation planning. Transportation Research Part A, 2. 105-116. o.

Griffith-Jones, S. - Ocampo, J.-A. (2009): The financial crisis and its impact on developing countries. Working Paper, 53, International Policy Centre for Inclusive Growth.

Guillaumont, P. - Chauvet, L. (2001): Aid and performance: A reassessment. Journal of Development Studies, 6, 66-87. o.

Guillaumont, P. (2008): An Economic Vulnerability Index: Its design and use for international development policy. UNU WIDER Research Paper, 2008/99, United Nations University World Institute for Development Economics Research, Helsinki.

Gunter, B. G. - Rahman, J. - Wodon, Q. (2008): Robbing Peter to pay Paul? Who pays for debt relief. World Development, 1, 1-16. o.

Haddad, M. E. - Lim, J. J. - Saborowsky, C. (2010): Trade openness reduces growth volatility when countries are well diversified. Policy Research Working Paper, 5222, The World Bank.

Hallaert, J. J. - Munro, L. (2009): Binding constraints to trade expansion: Aid for Trade objectives and diagnostic tools. OECD Trade Policy Working Paper, 94, OECD.

Hansen, H. - Tarp, F. (2001): Aid and growth regressions. Journal of Development Economics, 2, 547-570. o.

Hanson, M. - Hentz, J. J. (1999): Neocolonialism and neoliberalism in South Africa and Zambia. Political Science Quarterly, 3, 479-502. o.

Head, K. - Mayer, T. - Ries, J. (2010): The erosion of colonial trade linkages after independence. Journal of International Economics, 1, 1-14. o.

Helble, M. - Mann, C. - Wilson, J. S. (2009): Aid for Trade Facilitation. Policy Research Working Paper, 5064, The World Bank.

Held, D. (2005): At the global crossroads: the end of the Washington consensus and the rise of global social democracy? Globalization, 1, 95-113. o.

Heritage Foundation - WSJ (2011): Index of economic freedom 2011. The Heritage Foundation The Wall Street Journal. Letölthető: http://www.heritage.org/index/ranking (Letöltve: 2011. november 23.)

Herzer, D. - Klasen, S. - Nowak-Lehman D., F. (2008): In search of FDI-led growth in developing countries: The way forward. Economic Modelling, 5, 793-810. o. 
Hinkle, L. E. - Schiff, M. (2004): Economic Partnership Agreements between Sub-Saharan Africa and the EU: A development perspective. The World Economy, 9, 1321-1333. o.

Hinkle, L. E. - Hoppe, M. - Newfarmer, R. (2005): Beyond Cotonou: Economic Partnership Agreements in Africa. In Newfarmer, R. (ed.): Trade, Doha, and development. A window into the issues. The World Bank, Washington, D. C., 267-280. o.

Hoeffler, A. (2008): Dealing with the consequences of violent conflicts in Africa. Background Paper, African Development Bank.

Hoekman, B. (2002): Strengthening the global trade architecture for development. Policy Research Working Paper, 2757, The World Bank.

Hoekman, B. (2006): More favourable treatment of developing countries: ways forward. In Newfarmer, R. (ed): Trade, Doha, and Development. A window into the issues. The World Bank, Washington D.C., 213-221. o.

Hoekman, B. - Özden, C. (2005): Trade preferences and differential treatment of developing countries: a selective survey. Policy Research Working Paper, 3566, The World Bank.

Hoekman, B. - Wilson, J. S. (2010): Aid for Trade: Building on progress today for tomorrow's future. Policy Research Working Paper, 5361, The World Bank.

Holland, M. (2008): The EU and the Global Development Agenda. European Integration, 3, 343 362. 0.

Horváth Z. (2005): Kézikönyv az Európai Unióról (6. átdolgozott, bövitett kiadás). HVG-ORAC Lap- és Könyvkiadó Kft., Budapest.

Horváthné Angyal B. (2010): A nemzetközi segélyezés mikroökonómiai megközelítésben. Közvagy magánjószág-e a sagely? Köz-Gazdaság, 2, 189-205. o.

Hout, W. (1996): Development strategies and economic performance in Third World countries, 1965-1992. Third World Quarterly, 4, 603-624. o.

Huchot-Bourdon, M. - Lipchitz, A. - Rousson, A. (2009): Aid for Trade in developing countries: Complex linkages for real effectiveness. African Development Review, 2, 243-290. o.

Hudson, J. - Mosley, P. (2008): The macroeconomic impact of aid volatility. Economics Letters, 3 , 486-489. o.

Hurt, S. R. (2003): Co-operation and coercion? The Cotonou Agreement between the European Union and ACP states and the end of the Lomé Convention. Third World Quarterly, 1, 161176. o.

Irandoust, M. - Ericsson, J. (2005): Foreign aid, domestic savings, and growth in LDCs: An application of likelihood-based panel cointegration. Economic Modelling, 4, 616-627. o.

Irogbe, $K$. (2005): Globalization and the development of underdevelopment of the Third World. Journal of the Third World Studies, 1, 41-68. o.

Irwin, D. (2003): Trade and development: A review of the debate. Background Paper for UN Millennium Project, International Task Force on Trade.

Islam, M. N. (2003): Political regimes and the effects of foreign aid on economic growth. Journal of Developing Areas, 1, 35-53. o.

Jakab M. Z. - Kovács M. A. - Oszlay A. (2000): A külkereskedelmi integráció: becslések három kelet-közép-európai ország egyensúlyi külkereskedelmére. Közgazdasági Szemle, 9, 719-740. o.

Jakab P. (2005): Magyarország részvétele a fejlesztési segítségnyújtásban. In Gömbös E. (szerk.): A nemzetközi fejlesztési együttmüködés a XXI. században. Magyar ENSZ Társaság, HUNIDA Kht., Budapest, 255-260. o. 
Jameson, K. P. (2008): Institutionalist development economics. In Dutt, A. K. - Ros, J. (szerk.) (2008): International Handbook of Development Economics. Edward Elgar, Cheltenham és Northampton, 162-175. o.

Jayanthakumaran, $K$. (2000): Industrialization: import substitution to export promotion. Working Paper, WP 00-09, University of Wollongong, Department of Economics.

Jilberto, A. E. F. - Mommen, A. (2003): Setting the neoliberal development agenda. Structural adjustment and export-led industrialization. In Jilberto, A. E. F. - Mommen, A. (eds.): Liberalization in the developing world. Institutional and economic changes in Latin-America, Africa and Asia. Routledge, London-New York.

Kacsirek L. (1993): A holland kór. Miért okozhat problémákat az exportjövedelmek gyors növekedése? Közgazdasági Szemle, 6, 483-498. o.

Kacsirek L. (2010): Az EU-USA-banánvita és ami mögötte van. Fordulat, 8, 106-136. o.

Kalyvitis, S. - Vlachaki, I. (2011): When does more aid imply less democracy? An empirical examination. European Journal of Political Economy, article in press (available on-line: 2 July 2011).

Kanbur, $R$. (2001): Cross-border externalities, international public goods and their implications for aid agencies. Working Paper, 2001-03, Department of Applied Economics and Management, Cornell University, Ithaca, New York.

Kanbur, R. (2010): The role of the World Bank in middle income countries. Letölthetö: http://kanbur.dyson.cornell.edu/papers/The\%20Role\%20of\%20the\%20World\%20Bank\%20in \%20Middle\%20Income\%20Countries.pdf (Letöltve: 2011. november 1.)

Karbasi, A. - Tavana, H. (2009): The impact of industry and foreign trade on economic growth. Proceedings of World Academy of Science, Engineering and Technology, 37, 1322-1337. o.

Karingi, S. - Lang, R. - Oulmane, N. - Perez, R. - Jallab, M. S. - Hammouda, H. B. (2005): Economic and welfare impacts of the EU-Africa Economic Partnership Agreements. Work in Progress, 10, African Trade Policy Centre.

Kebonang, Z. (2007): Generosity undermined: the Cotonou Agreement and the African Growth and Opportunity Act. Development in Practice, 1, 98-103. o.

Ketchen, D. J. - Shook, C. L. (1996): The application of cluster analysis in strategic management research: An analysis and critique. Strategic Management Journal, 6, 441-458. o.

Khin, E. W. S. (2010): Transforming China poverty crisis: Challenges and issues. US-China Law Review, 1, 42-50. o.

Kimura, H. - Todo, Y. (2010): Is foreign aid a vanguard of foreign direct investment? A gravityequation approach. World Development, 4, 482-497. o.

Kiss J. (2002): Az Európai Unió és az Amerikai Egyesült Államok kereskedelmi vitái. Külgazdaság, 2, 47-69. o.

Kiss J. (2007a): Az Európai Unió fejlesztéspolitikai dilemmái. Fejlesztés és Finanszírozás, 1, 4049. o.

Kiss J. (2007b): A magyar nemzetközi fejlesztéspolitika a számok tükrében. Nemzetközi Humanitárius és Fejlesztési Civil Szövetség, Budapest.

Kojima, K. (2000): The „flying geese" model of Asian economic development: origin, theoretical extensions, and regional policy implications. Journal of Asian Economics, 11, 375-401. o.

Kosack, S. (2003): Effective aid: how democracy allows development aid to improve the quality of life. World Development, 1, 1-22. o.

Kovács P. (2008): A multikollinearitás vizsgálata lineáris regressziós modellekben. Statisztikai Szemle, 1, 38-67. o. 
Kovács P. - Petres T. - Tóth L. (2006): Válogatott fejezetek statisztikából: többváltozós statisztikai módszerek. JATEPress, Szeged.

Krugman, P. R. - Obstfeld, M. (2003): Nemzetközi gazdaságtan. Elmélet és gazdaságpolitika. Panem Könyvkiadó Kft, Budapest.

Laird, S. (2007): Aid for Trade - Cool aid or Kool-aid? G-24 Discussion Paper, 48, UNCTAD, New York and Geneva.

Laux-Meiselbach, W. (1989): A note on import substitution versus export promotion as strategies for development. Kyklos, 2, 219-229. o.

Lawal, G. (2006): The normative impedepements to African development: internalist and externalist interpretations. Journal of Applied Science Research, 2, 637-641. o.

Lee, H. Y. - Ricci, L. A. - Rigobon, R. (2004): Once again, is openness good for growth? Journal of Development Economics, 2, 451-472. o.

Lee, Y.-S. (2005): Foreign direct investment and regional trade liberalization: a viable answer for economic development? Journal of World Trade, 4, 701-717. o.

Leeson,P. F. - Nixson, F. I. (2004): Development Economics in the Department of Economics at the University of Manchester. Journal of Economic Studies, 1, 6-24. o.

Lehmijoki, U. - Palokangas, T. (2006): Political instability, gender discrimination, and population growth in developing countries. Journal of Population Economics, 2, 431-446. o.

Lengyel I. (2000): A regionális versenyképességröl. Közgazdasági Szemle, 12, 962-987. o.

Levy-Orlik, N. (2009): Protectionism and industrialisation: A critical assessment of the Latin American industrialization period. Brazilian Journal of Political Economy, 4, 436-453. o.

Lightfoot, S. (2008): Enlargement and the challenge of EU development policy. Perspectives on European Politics and Society, 2, 128-142. o.

Lightfoot, S. (2010): Europeanisation of international development policies: the case of Central and Eastern European states. Europe-Asia Studies, 2, 329-350. o.

Loxley, J. - Sackey, H. A. (2008): Aid effectiveness in Africa. African Development Review, 2, 163-199. o.

Lukovics M. (2008): Térségek versenyképességének mérése. JATEPress, Szeged.

Lukovics M. - Lóránd B. (2010): A versenyképesség és a pályázati forrásallokáció kistérségi szinten. Tér és Társadalom, 4, 81-102. o.

Mahler, V. A. (1994): The Lomé Convention: Assessing a North-South institutional relationship. Review of International Political Economy, 2, 233-256. o.

Manole, V. - Spatareanu, M. (2010): Trade openness and income - A re-examination. Economic Letters, 1, 1-3. o.

Marysse, S. - Ansoms, A. - Cassimon, D. (2007): The aid 'darlings' and 'orphans' of the Great Lake region in Africa. European Journal of Development Research, 3, 433-458. o.

McCleery, R. K. - de Paolis, F. (2008): The Washington consensus: a post-mortem. Journal of Asian Economics, 5-6, 438-446. o.

McGillivray, M. - Feeny, S. - Hermes, N. - Lensink, R. (2005): It works; It doesn't; It can, but that depends... 50 years contoversery over the macroeconomic impact of development aid. Research Paper, 2005/54, United Nations University, World Institute for Development Economics Research (UNU-WIDER).

McKinley, T. (2005): Why is the 'Dutch Disease' always a disease? The macroeconomic consequences of scaling up ODA. Working Paper, 10, International Poverty Centre, United Nations Development Programme. 
Meschi, E. - Vivarelli, M. (2009): Trade and income inequality in developing countries. World Development, 2, 287-302. o.

Meyn, M. (2008): Economic Partnership Agreements: A 'Historic Step' towards a 'Partnership of Equals'? Development Policy Review, 5, 515-528. o.

Mészáros Á. (2004): A magyarországi közvetlen külföldi müködőtőke-beruházások exportenklávé jellege. Külgazdaság, 4, 48-59. o.

Mészáros Á. (2008): Regionális integrációk a világgazdaságban. In Blahó A. et al (2008): Világgazdaságtan. Akadémiai Kiadó, Budapest, 251-279. o.

Mészáros Á. (2011): Közvetlen külföldi beruházások integráltsága a beszállitói kapcsolatok tükrében: a magyarországi Suzuki példája. PhD értekezés, Budapesti Müszaki és Gazdaságtudományi Egyetem Gazdaság és Társadalomtudományi kar.

Migliorisi, S. - Phamtam, M. - Rampulla, C. (2003): The consequences of enlargement for development policy. Final Report. Development Strategies - IDC.

Montes, C. - Migliorisi, S. (2004): EU Donor Atlas. Mapping Official Development Assistance. Development Strategies and IDC.

Moreau, F. (2000): The Cotonou Agreement - new orientations. The ACP-EU Courier (Special Issue), 9, 6-10. o.

Moreira, E. P. (2010): Aid for Trade, infrastructure, and the growth effects of trade reform. Issues and implications for Caribbean countries. Policy Research Working Paper, 5265, The World Bank.

Morgera, E. - Durán, G. M. (2004): Enlargement and EU development policy: An environmental perspective. Review of European Community and International Environmental Law, 2, 152163. o.

Moss, T. - Pettersson, G. - Van de Walle, N. (2006): An aid-institutions paradox? A review essay on aid dependency and state building in Sub-Saharan Africa. Working Paper, 74, Center for Global Development, Washington.

Mountford, A. - Rapoport, H. (2011): The brain drain and the world distribution of income. Journal of Development Economics, 1, 4-17. o.

Myrdal, G. (1957): Economic theory and under-developed regions. Gerald Duckworth \& Co. Ltd., London.

Nafziger, E. W. (2006): Economic development. Fourth edition. Cambridge University Press, New York.

Naito, T. (2010): Aid for Trade and Global Growth. Working Paper. Letölthetö: http://ssrn.com/abstract=1335615 (Letöltve: 2010 . június 17.)

Naqvi, S. N. H. (1996): The significance of development economics. World Development, 6, 975987. 0.

Ndikumana, L. (2004): Additionality of debt relief and debt forgiveness, and implications for future volumes of official assitance. International Review of Economics \& Finance, 3, 325-340. o.

Ndikumana, L. - Abderrahim, K. (2010): Revenue mobilization in African countries: Does natural resource endowment matter? African Development Review, 3, 351-365. o.

Nenci, S. - Pietrobelli, C. (2007): Does tariff liberalization promote trade? Latin America in the long-run (1900-2000). CREI Working Paper, 4/2007, CREI Università degli Studi Roma Tre.

Németh N. - Kiss J. P. (2007): Megyéink és kitérségeink belső jövedelmi tagoltsága. Területi Statisztika, 1, 20-45. o. 
Ng, F. - Yeats, A. (1997): Open economies work better! Did Africa's protectionist policies cause its marginalization in world trade? World Development, 6, 889-904. o.

Nielson, P. (2000): The new agreement will benefit the poorest. The ACP-EU Courier (Special Issue), 9, 2-4. o.

Nilsson, L. (2011): The European Commission's proposal for the next EU Generalised System of Preferences. Virtual proceedings, European Trade Study Group International Conference, 15 o. Letölthetö: http://www.etsg.org/ETSG2011/Papers/Nilsson.pdf

Noland, M. (2005): Religion and economic performance. World Development, 8, 1215-1232. o.

North, D. C. (1991): Institutions. Journal of Economic Perspectives, 1, 97-112. o.

Nowak-Lehmann D., F. - Martínez-Zarzoso, I. - Cardozo, A. - Herzer, D. (2011): Does Aid translate into Bilateral Trade? Findings for Recipient Countries. 61, Proceedings of the German Development Economics Conference, Berlin 2011 from Verein für Socialpolitik, Research Committee Development Economics.

Nunn, A. - Price, S. (2004): Managing development: EU and African relations through the evolution of the Lomé and Cotonou Agreements. Historical Materialism, 4, 203-230. o.

Nurse, K. - Francis, A. - Niles, K. (2008): The Economic Partnership Agreement and beyond: The case for innovation and industrial policy. Journal of Eastern Caribbean Studies, 2, 69-103. o.

ODI (2006): The potential effects of Economic Partnership Agreements: What quantitative models say. Briefing Paper, June, Overseas Development Institute, London.

OECD (2010): Net official development assistance in 2010. Letölthető: http://www.oecd.org/dataoecd/54/41/47515917.pdf (Letöltve: 2011. november 23.)

OECD (2011a): History of DAC Lists of aid recipient coutnries. Letölthető: http://www.oecd.org/document/55/0,3746,en_2649_34447_35832055_1_1_1_1,00.html (Letöltve: 2011. október 24.)

OECD (2011b): DAC List of ODA recipients. Letölthetö: http://www.oecd.org/dataoecd/9/50/48858205.pdf (Letöltve: 2011. október 24.)

OECD-CRS (2011): Aid for Trade Statistical Queries. Letölthetö: http://www.oecd.org/document/21/0,3343,en_2649_34665_43230357_1_1_1_1,00.html (Letöltve: 2011. július 20.)

OECD DAC (2011): DAC members and date of membership. Letölthető: http://www.oecd.org/document/5/0,3343,en_2649_34603_1893350_1_1_1_1,00.html (Letöltve: 2011. július 27.)

OECD - WTO (2011): Aid for Trade at a glance 2011: Showing the results. Organisation for Economic Cooperation and Development - World Trade Organization, Paris - Geneva.

Okafor, L. E. - Tyrowicz, J. (2010): Saving less when there is more foreign lending? Foreign debt and savings in developing countries. Journal of Economic Policy Reform, 3, 213-223. o.

O'Neill, H. (2005): The MDGs and the three Cs. In Gömbös E. (szerk.): A nemzetközi fejlesztési együttmüködés a XXI. században. Magyar ENSZ Társaság, HUNIDA Kht., Budapest, 83-95. o.

Osei, R. - Morrissey, O. - Lloyd, T. (2004): The nature of aid and trade relationships. European Journal of Development Research, 2, 354-374. o.

Otto, G. (2003): Terms of trade shocks and the balance of trade: there is a Harberger-LaursenMetzler effect. Journal of International Money and Finance, 2, 155-184. o.

Ozawa, T. (2001): The „hidden” side of the „flying geese” catch-up model: Japan's dirigiste institutional setup and a deepening financial morass. Journal of Asian Economics, 12, 471491. o. 
Ozawa, T. (2005): Institutions, industrial up-grading, and economic performance in Japan. The 'flying geese' paradigm of catch-up growth. Edward Elgar Publishing Limited, Cheltenham.

Oyewumi, A. (1991): The Lome Convention. Round Table, 1, 129-138. o.

Öniş, Z. - Şenses, F. (2005): Rethinking the emerging post-Washington consensus. Development and Change, 2, 263-290. o.

Özden, C.. - Reinhardt, E. (2005): The perversity of preferences: GSP and developing country trade policies, 1976-2000. Journal of Development Economics, 1, 1-21. o.

Pacheco-Lopez, P. (2005): The effect of trade liberalization on exports, imports, the balance of trade, and growth: the case of Mexico. Jouranl of Post Keynesian Economics, 4, 595-619. o.

Page, S. (2007): The Potential Impact of Aid for Trade Initiative. G-24 Discussion Papers, 45, UNCTAD, Geneva.

Pagliari, C. - Bucciarelli, E. - Alessi, M. (2011): Interdependence of world markets: economic growth and social well-being. Procedia Computer Science, 3, 732-741. o.

Palma, J. G. (2008a): Structuralism. In Dutt, A. K. - Ros, J. (szerk.) (2008): International Handbook of Development Economics. Edward Elgar, Cheltenham és Northampton, 136-143. o.

Palma, J. G. (2008b): Theories of dependency. In Dutt, A. K. - Ros, J. (szerk.) (2008): International Handbook of Development Economics. Edward Elgar, Cheltenham és Northampton, 125-135. o.

Paragi B. - Szent-Iványi B. - Vári S. (2007): Nemzetközi fejlesztési segélyezés: tankönyv. TeTT Consult Kft., Budapest.

Parfitt, T. (1996): The decline of Euroafrica? Lomé's mid-term review. Review of African Political Economy, 67, 53-66. o.

Pataki Gy. (1998): A fejlődés gazdaságtana és etikája - Tiszteletadás Amartya Sen munkásságának. Kovász, 4, 6-17. o.

Persson, M. - Wilhelmsson, F. (2006): Assessing the effects of EU trade preferences for developing countries. Working Paper, 4, Lund University, Lund.

Pettersson, J. - Johansson, L. (2011): Aid, Aid for Trade, and bilateral trade: An empirical study. Journal of International Trade and Economic Development, forthcoming.

Phan, T. H. H. (2010): Effects of the 2008 financial crisis on developing Asia's economic growth. Economics Bulletin, 3, 1922-1934. o.

Phelps, N. A. - Stillwell, J. C. H. - Wanjiru, R. (2009): Broken Chain? AGOA and Foreign Direct Investment in the Kenyan Clothing Industry. World Development, 2, 314-325. o.

Piasecki, R. - Wolnicki, M. (2004): The evolution of development economics and globalization. International Journal of Social Economics, 3, 300-314. o.

Powell, R. - Bird, G. (2010): Aid and debt relief in Africa: have they been substitutes or complements? World Development, 3, 219-227. o.

Puntasen, A. (2010): A buddhista közgazdaságtan szükségessége. In Zsolnai L. (szerk.): Boldogság és gazdaság. A buddhista közgazdaságtan eszméi. Typotex, Budapest, 117-141. o.

Rajan, R. G. - Subramanian, A. (2008): Aid and growth: what does the cross-country evidence really show? Review of Economics and Statistics, 4, 643-665. o.

Rajan, R. - Subramanian, A. (2011): Aid, Dutch disease, and manufacturing growth. Journal of Development Economics, 1, 106-118. o.

Ranis, G. (2003): Is dualism worth revisiting? Center Discussion Paper, 870, Economic Growth Center, Yale University. 
Ranis, G. (2004a): The evolution of development thinking: theory and policy. Center Discussion Paper, 886, Economic Growth Center, Yale University, New Haven.

Ranis, G. (2004b): Arthur Lewis's contribution to development thinking and policy. Center Discussion Paper, 891, Economic Growth Center, Yale University, New Haven.

Rashid, S. (2008): Neoclassical development economics. In Dutt, A. K. - Ros, J. (szerk.) (2008): International Handbook of Development Economics. Edward Elgar, Cheltenham és Northampton, 176-186. o.

Ravallion, M. (2009): Are there lessons for Africa from China's success against poverty? World Development, 2, 303-313. o.

Rees, G. - Smith, C. (1998): Economic development. Macmillan Press Ltd, London.

Rodrigues, M. (2010): Import substitution and economic growth. Journal of Monetary Economics, 2, 175-188. o.

Rodríguez, F. - Rodrik, F. (1999): Trade policy and economic growth: a skeptic's guide to the cross-national evidence. NBER Working Paper, 7081, National Bureau of Economic Research, Cambridge.

Roodman, D. (2007): Macro aid effectiveness: A guide for the perplexed. Working Paper, 134, Center for Global Development.

Ros, J. (2008): Classical development theory. In Dutt, A. K. - Ros, J. (szerk.): International Handbook of Development Economics. Edward Elgar, Cheltenham és Northampton, 111-124. o.

Rostow, W. W. (1990): Theorists of economic growth from David Hume to the present: with a perspective on the next century. Oxford University Press, Oxford, New York.

Sajtos L. - Mitev A. (2007): SPSS kutatási és adatelemzési kézikönyv. Alinea Kiadó, Budapest.

Salahuddin, M. - Islam, R. (2008): Factors affecting investment in developing countries: a panel data study. Journal of Developing Areas, 1, 21-37. o.

Sandbrook, R. (2005): Africa's great transformation? Journal of Development Studies, 6, 1118 1125. o.

Santos, S. (1997): Lomé Convention. Government Institute for Economic Research, Helsinki.

Sarkar, P. (2001): The North-South terms of trade debate: a re-examination. Progress in Development Studies, 4, 309-327. o.

Scheiring G. (2010): A nemzetközi fejlesztéspolitika helyzete és feladata. Fordulat, 8, 60-82. o.

Sen, A. (2003): A fejlödés mint szabadság. Európa Könyvkiadó, Budapest.

Senhadji, A. (1998): Dynamic of the trade balance and the terms of trade in LDCs: The S-curve. Journal of International Economics, 1, 105-131. o.

Sentsho, J. (2003): Export revenues as determinants of economic growth: evidence from Botswana. Letölthetö:

http://www.essa.org.za/download/2003Conference/SentshoJ_Exports\%20Revenue\%20\&\%20 Economic\%20GrowthF.pdf (Letöltve: 2010. április 18.)

Seyoum, B. (2006): US trade preferences and export performance of developing countries: Evidence from the generalized system of preferences. International Business Review, 1, 68-83. o.

Shaffaedin, M. - Pizarro, J. (2007): From export promotion to import substitution; comparative experience of China and Mexico. MPRA Paper, 6650, Munich Personal RePEc Archive.

Shams, R. (2005): The drive to economic integration Africa. HWWA Discussion Paper, 316, Hamburg Institute of International Economics. 
Shortland, A. (2011): "Robin Hook": The development effects of Somali piracy. Discussion Papers, 1155, Deutsches Institut für Wirtshatsforschung, Berlin.

Shorthland, A. - Vothknecht, M. (2011): Combating ,maritime terrorism” off the coast of Somalia. European Journal of Political Economy, In press, available online 8 April 2011.

Slocum-Bradely, N. - Bradely, A. (2010): Is the EU's governance 'good'? An assessment of EU governance in its partnership with ACP states. Third World Quarterly, 1, 31-49. o.

Simai M. (1981): A fejlödő országok és a gazdasági dekolonizáció. Kossuth Könyvkiadó, Budapest.

Simai M. (2008): A világgazdaság a XXI. század forgatagában: új trendek és stratégiák. Akadémiai Kiadó, Budapest.

Somai M. (1997): A GATT-ból a WTO-ba: az Uruguayi forduló elözményei és eredményei. Külgazdaság, 10, 4-20. o.

Södersten, B. (1985): A külgazdaság hatásmechanizmusa. Közgazdasági és Jogi Könyvkiadó, Budapest.

Spaventa, A. (1999): The Lomé Convention. Objectives, instrument, results. Federico Caffe Centre Research Reports, 2, Roskilde University, Denmark.

Stiglitz, J. E. (2003): A globalizáció és visszásságai. Napvilág Kiadó, Budapest.

Stiglitz, J. E. - Charlton, A. (2006): Aid for Trade. International Journal of Development Issues, 2, $1-41.0$

Stoneman, C. - Suckling, J. (1987): From apartheid to neocolonialism? Third World Quarterly, 2, 515-544. o.

Streeten, P. (1983): A gazdasági fejlődés-elméletek kialakulása. In Béládi L. - Miszlivetz F. (szerk.): Kritikai elméletek és elméletkritikák. Fejlödés-tanulmányok. Eötvös Lóránd Tudományegyetem, Budapest, 221-231. o.

Streeten, P. (1998): The cheerful pessimist: Gunnar Myrdal the dissenter (1898-1987). World Development, 3, 539-550. o.

Subasat, T. (2002): Does export promotion increase economic growth? Some cross-section evidence. Development Policy Review, 3, 333-349. o.

Subasat, T. (2009): Does simultaneous implementation of import-substitution and exportpromotion neutralize each other? Journal of Developing Areas, 1, 45-63. o.

Subramanian, A. - Tamirisa, N. T. (2003): Is Africa integrated in the global economy? IMF Staff Papers, 3, 352-372. o.

Summer, A. (2010): Global poverty and the new 'bottom billion': What if three-quarters of the world's poor live in middle-income countries? Working Paper, 349, Institute of Development Studies.

Sumner, A. (2006): In search of the Post-Washington (dis)consensus: the 'missing' content of PRSPS. Third World Quarterly, 8, 1401-1412. o.

Sutcliffe, B. (2008): Marxism and development. In Dutt, A. K. - Ros, J. (szerk.) (2008): International Handbook of Development Economics. Edward Elgar, Cheltenham és Northampton, 144-161. o.

Szakolczai Gy. (2006): A gazdasági fejlődés elméletének megújulása: az első, a második és az új generáció. Valóság, 3, 1-35. o.

Szentes T. (1976): Az elmaradottság és fejlettség dialektikája a tökés világgazdaságban. Kossuth Könyvkiadó, Budapest.

Szentes T. (1999): Világgazdaságtan. Elméleti és módszertani alapok. Aula Kiadó, Budapest. 
Szentes, T. (2002): World economics I. Comparative theories and methods of international and development economics. Akadémiai Kiadó, Budapest.

Szentes T. (2005): Fejlödés és segélyezési politika a felgyorsult globalizáció és regionalizálódás korában. In Gömbös E. (szerk.): A nemzetközi fejlesztési együttmüködés a XXI. században. Magyar ENSZ Társaság, HUNIDA Kht., Budapest, 29-53. o.

Szentes T. (2011): Fejlödés-gazdaságtan. Akadémiai Kiadó, Budapest.

Szent-Iványi B. (2006): Az államkudarcok kérdése a nemzetközi fejlesztési együttmüködésben. In Marton P. (szerk.): Államok és államkudarcok a globalizálódó világban. Teleki László Intézet Külpolitikai Tanulmányok Központja, 80-96. o.

Szent-Iványi B. (2008): A szabadkereskedelmi tárgyalások nehézségei. Esettanulmány az EUAKCS gazdasági társulási megállapodásokról. In Blahó A. (szerk.): Nemzetgazdaság integráció - világgazdaság. Tanulmányok Palánkai Tibor 70. születésnapja tiszteletére. Budapesti Corvinus Egyetem, Budapest.

Szent-Iványi B. (2009a): A visegrádi országok nemzetközi fejlesztési segélyeinek allokációja. KülVilág, a nemzetközi kapcsolatok folyóirata, 3, 26-45. o.

Szent-Iványi B. (2009b): A nemzetközi fejlesztési segélyezés hatékonysága. Ph.D. értekezés, Budapesti Corvinus Egyetem, Nemzetközi Kapcsolatok Doktori Iskola.

Székelyi M. - Barna I. (2005): Túlélökészlet az SPSS-hez. Többváltozós elemzési technikákról társadalomkutatók számára. Typotex, Budapest.

Ter Haar, G. - Ellis, S. (2006): The role of religion in development: towards a new relationship between the European Union and Africa. European Journal of Development Research, 3, 351367. o.

Timmer, C. P. (2010): Reflections on food crises past. Food Policy, 1, 1-11. o.

Todaro, M. P. - Smith, S. C. (2009): Economic development. Pearson Education Limited, Harlow.

Tuman, J. P. - Strand, J. R. - Emmert, C. F. (2009): The disbursement pattern of Japanese foreign aid: a reappraisal. Journal of East Asian Studies, 2, 219-248. o.

Turner, L. (2008): Quantifying Aid for Trade: a case study of Tanzania. Economic Paper Series, 82, Commonwealth Secreteriat, London.

UCDP/PRIO (2011): Armed conflict dataset, v.4-2011, 1946-2010. Interneten: http://www.pcr.uu.se/research/ucdp/datasets/ucdp_prio_armed_conflict_dataset/ (Letöltve: 2012. április 10.)

Udvari, B. (2009a): World Trade Organization as a development institution? Development and Finance, 4, 72-81. o.

Udvari B. (2009b): A Kereskedelmi Világszervezet mint fejlesztési intézmény? Fejlesztés és Finanszírozás, 4, 72-81. o.

Udvari B. (2010a): Mindenki ugyanannyit veszít? - A fejlődő országok és a TRIPS Egyezmény gyógyszerkereskedelemre vonatkozó szabályai. Fordulat, 8, 84-104. o.

Udvari, B. (2010b): Is free market access enough for development? - Lessons of the Lomé Conventions. In Kovács, P. - Szép, K. - Katona, T. (eds.): Proceedings of the Challenges for analysis of the economy, business, and social progress. Unidocument Kft., Szeged, 77-96. o.

Udvari B. (2010c): Aid for Trade. “Régi-új” fejlesztési eszköz az Európai Unióban. Európai Tükör, 6, 28-42. o.

Udvari B. (2010d): Nemzetközi kereskedelem és gazdasági fejlödés: a Loméi Egyezmények tanulságai. Külgazdaság, 5-6, 59-80. o. 
Udvari, B. (2011a): The TRIPS Agreement and access to medicines: who are the main losers? In Farkas, B. (ed.): Studies in International Economics and Finance. JATEPress, Szeged, 157179. o.

Udvari B. (2011b): Az Aid for Trade program és a legkevésbé fejlett országok: ki a fó kedvezményezett? Külgazdaság, 7-8, 33-55. o.

Ukpe, A. I. (2010): Will EPAs foster African integration into world trade? Journal of African Law, 2, 212-231. o.

UN (2000): Millennium Development Goals. http://www.un.org/millenniumgoals/ (Letöltve: 2009. június 16.)

UN (2003): Monterrey Consensus of the International Conference on Financing for Development. United Nations Department of Public Information, New York.

UN (2008): Doha Declaration on financing for development: outcome document of the Follow-up International Conference on Financing for Development to Review the implementation of the Monterrey Consensus. A/Conf.212/L.1/Rev.1, United Nations, Doha, Quatar.

UN (2011a): Global Issues. Letölthető: http://www.un.org/en/globalissues/index.shtml (Letöltve: 2011. november 13.)

UN (2011b): Country Grouping Glossary. Letölthetö: http://cyberschoolbus.un.org/infonation3/glossary.html\#DevedEco (Letöltve: 2011. január 13.)

UN (2011c): List of Country Grouping and Sub-Grouping for the Analytical Studies of the United Nations World Economic Survey and other UN Reports. Letölthetö: http://unpan1.un.org/intradoc/groups/public/documents/un/unpan008092.pdf (Letöltve: 2011. január 14.)

UN (2011d): Statistics Division. Letölthetö: http://unstats.un.org/unsd/snaama/selbasicFast.asp (Letöltve: 2011. január 10.)

UNCTAD (2005a): Trade and Development Report, 2005. United Nations Conference on Trade and Development, New York and Geneva.

UNCTAD (2005b): Developing countries in international trade 2005: Trade and Development Index. United Nations Conference on Trade and Development, New York and Geneva.

UNCTAD (2007): Trade and Development Report, 2007. United Nations Conference on Trade and Development, New York and Geneva.

UNCTAD (2008a): Aid for Trade and development: Global and regional perspectives. United Nations Conference on Trade and Development, New York and Geneva.

UNCTAD (2008b): Export performance following trade liberalization: some patterns and policy perspectives. United Nations Conference on Trade and Development, New York and Geneva.

UNCTAD (2009): Economic development in Africa. Report 2009. Strengthening regional economic integration for Africa's development. United Nations Conference on Trade and Development, New York and Geneva.

UNCTAD (2010): World Investment Report 2010. Investing in a low-carbon economy. United Nations Conference on Trade and Development, New York and Geneva.

UNCTAD (2011): UNCTADStat. http://unctadstat.unctad.org/ReportFolders/reportFolders.aspx (Letöltve: 2011. január 4.)

UNDP (1996): Human Development Report 1996. Economic growth and human development. United Nations Development Program, New York.

UNDP (2007): Making globalization work for all. Annual Report, United Nations Development Program, New York. 
UN-OHRLLS (2011a): Criteria for identification of LDC. Letölthetö: http://www.unohrlls.org/en/ldc/related/59/ (Letöltve: 2011. május 16.)

UN-OHRLLS (2011b): Least-Developed Countries: Country Profiles. Letölthető: http://www.unohrlls.org/en/ldc/related/62/ (Letöltve: 2011. január 13.)

UN-OHRLLS (2011c): Landlocked Developing Countries. Letölthető: http://www.unohrlls.org/en/lldc/39/ (Letöltve: 2011. május 16.)

UN-OHRLLS (2011d): Small island developing states. Letölthetö: http://www.unohrlls.org/en/sids/43/ (Letöltve: 2011. május 16.)

Vanasse, R. B. (1988): The UN New International Economic Order: a brief analysis. World Affairs, 4, 233-238. o.

Vijil, M. - Wagner, L. (2010): Does Aid for Trade enhance export performance? Investigating on the infrastructure channel. Virtual proceedings, European Trade Study Group International Conference, 42 o. Letölthető: http://www.etsg.org/ETSG2010/papers/Vijil_Wagner.pdf (Letöltve: 2011. február 1.)

Világbank (1991): World Development Report. The challenge of development. The World Bank, Washington, D. C.

Világbank (2011a): Country and Lending Groups. Letölthető: http://data.worldbank.org/about/country-classifications/country-and-lendinggroups\#Low_income (Letöltve: 2011. január 13.)

Világbank (2011b): World Development Indicators - on-line database. Letölthetö: http://databank.worldbank.org/ddp/home.do?Step=12\&id=4\&CNO=2 (Letöltve: 2011. augusztus 29.)

Világbank (2011c): World Development Report 2011. Conflict, security, and development. The World Bank, Washington, D. C.

Vollmer, S. - Martínez-Zarzoso, I. - Nowak-Lehmann D., F. - Klann, N-H. (2009): EU-ACP Economic Partnership Agreements. Empirical evidence for Sub-Saharan Africa. Proceedings of the German Development Economics Conference, Frankfurt a. M. 2009, 29 o.

Vos, R. - Ganuza, E. - Morley, S. - Robinson, S. - Pinerio, V. (2004): Are export promotion and trade liberalization good for Latin-America's poor? A comparative macro-micro CGE analysis. Working Paper, 339, Institute of Social Studies, The Hague, The Netherlands.

Wagner, D. (2003): Aid and trade - an empirical study. Journal of Japanese and International Economies, 2, pp. 153-173.

Wallerstein, I. (2006): World-system analysis. An introduction. Duke University Press, Durham, London.

Wallerstein, I. (2010): Bevezetés a világrendszer-elméletbe. L’Harmattan, Eszmélet Alapítvány, Budapest.

Weinberg, B. A. (2011): Developing science: Scientific performance and brain drains in the developing world. Journal of Development Economics, 1, 95-104. o.

Weller, P. - Yi-Chong, X. (2009): The World Bank: an institution with many faces. Social Alternatives, 2, 18-22. o.

White, H. (1992): The macroeconomic impact of development aid: a critical survey. Journal of Development Studies, 2, 163-240. o.

Whiteman, K. (1998): Africa, the ACP and Europe: the lessons of 25 years. Development Policy Review, 16, 29-37. o.

WHO (2009): Malaria $\quad-\quad$ key facts. http://www.who.int/mediacentre/factsheets/fs094/en/index.html (Letöltve: 2009. október 5.). 
Wilbur, W. L. - Haque, M. Z. (1992): An investigation of the export expansion hypothesis. Journal of Development Studies, 2, 297-313. o.

Williamson, J. (1994): In search of a manual for technopols. In Williamson, J. (ed.): The political economy of policy reform. Institute for International Economics, Washington, D. C., 11-28. o.

Winters, L. A. - McCulloch, N. - McKay, A. (2004): Trade liberalization and poverty: The evidence so far. Journal of Economic Literature, 1, 72-115. o.

WTO (2005): Doha Work Programme, Ministerial Declaration in Hong Kong. T/MIN(05)/W/3/Rev.2., 18 December.

WTO (2006): Recommendations of the Task Force on Aid for Trade. WT/AFT/1, World Trade Organization, Geneva.

WTO (2008): Principles of the trading system. http://www.wto.org/english/thewto_e/whatis_e/tif_e/fact2_e.htm (Letöltve: 2008. március 2.)

WTO (2011): The WTO and preferential trade agreements: from co-existence to coherence. World Trade Report 2011. World Trade Organization, Geneva.

Yaghmaian, B. (1994): An empirical investigation of exports, development, and growth in developing countries: Challenging the neoclassical theory of export-led growth. World Development, 12, 1977-1995. o.

Yanikkaya, H. (2003): Trade openness and economic growth: a cross-country empirical investigation. Journal of Development Economics, 1, 57-89. o.

Yin, X. - Yin, X. (2005): Can developing countries benefit from export promotion? Journal of Economic Studies, 1, 60-80. o.

Younas, J. (2008): Motivation for bilateral aid allocation: Altruism or trade benefits. European Journal of Political Economy, 3, 661-674. o.

Zhang, L.-Y. (2003): Background Paper. UNFCCC Workshop on Economic Diversification. Letölthető:

http://unfccc.int/files/meetings/workshops/other_meetings/application/pdf/bgpaper.pdf (Letöltve: 2010. február 25.)

Ziesemer, T. H. W. (2010): The impact of the credit crisis on poor developing countries: Growth, worker remittances, accumulation and migration. Economic Modelling, 5, 1230-1245. o.

Zsolnai L. (2010): Előszó: A buddhista közgazdaságtan horizontja. In Zsolnai L. (szerk.): Boldogság és gazdaság. A buddhista közgazdaságtan eszméi. Typotex, Budapest, 7-24. o. 


\section{SZÁMÚ MELLÉKLET: A FEJLŐDŐ ORSZÁGOK KÖRE}

Alacsony jövedelmú országok (GNI/fö < 1005 \$)

Afganisztán
Banglades
Benin
Bissau-Guinea
Burkina Faso
Burundi
Comore-szigetek
Csád
Dél-Korea
Eritrea
Etiópia
Gambia

Angola

Belize

Bhután

Bolívia

Djibouti

Egyiptom

El Salvador

Elefántcsontpart

Fidzsi

Fülöp-szigetek

Ghána

Guatemala

Guyana

Honduras

India

Indonézia

Irak

\author{
Guinea \\ Haiti \\ Kambodzsa \\ Kenya \\ Kongói Demokratikus \\ Köztársaság \\ Közép-afrikai Köztársaság \\ Libéria \\ Madagaszkár \\ Malawi \\ Mali \\ Mianmar
}

Mozambik

Nepál

Niger

Ruanda

Sierra Leone

Szomália

Tanzánia

Togo

Uganda

Zimbabwe

Alsó közepes jövedelmű országok $(1006 \$<$ GNI/fö <3975\$)

Jemen
Kamerun
Kiribati
Kongói Köztársaság
Laosz
Lesotho
Marokkó
Marshall-szigetek
Mauritánia
Mikronézia
Moldova
Mongólia
Nicaragua
Nigéria
Pakisztán
Pápua Új-Guinea
Paraguay

Salamon-szigetek Sao Tomé és Principe Sri Lanka

Szamoa

Szenegál

Szíria

Szudán

Szváziföld

Timor-Leste

Tonga

Tuvalu

Ukrajna

Vanuatu

Vietnám

Zambia

Zöldfoki-szigetek

Felső közepes jövedelmú országok $(3976 \$<$ GNI/fö $<12.275 \$)$

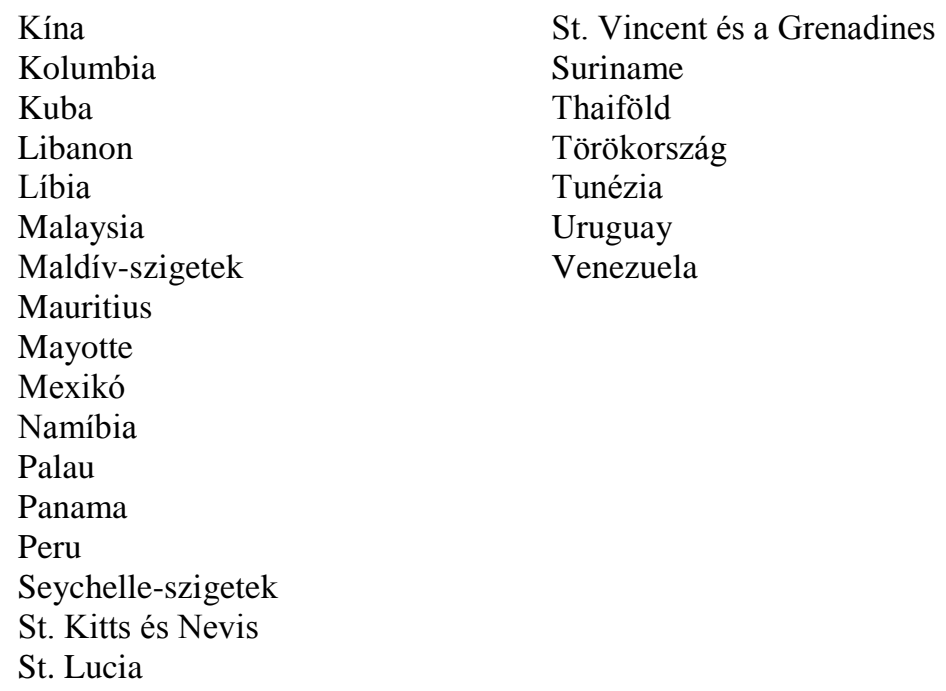

St. Vincent és a Grenadines

Suriname

Thaiföld

Törökország

Tunézia

Uruguay

Venezuela

Dél-afrikai Köztársaság

Dominika

Ecuador

Gabon

Grenada

Jamaica

Jordánia 
2. SZÁMÚ MELLÉKLET: AZ ORSZÁGOK KLASZTERTAGSÁGA A LOMÉI EGYEZMÉNYEK ELŐTT EREDETI VÁLTOZÓK, FAKTOROK

\begin{tabular}{|c|c|c|c|c|}
\hline Ország & Klaszter & $\begin{array}{c}\text { Klaszterközépponttól } \\
\text { mért távolság }\end{array}$ & $\begin{array}{c}\text { Klaszter } \\
\text { faktorral }\end{array}$ & $\begin{array}{c}\text { Klaszterközépponttól } \\
\text { mért távolság }\end{array}$ \\
\hline Angola & 4 & 2,56028 & 1 & 0,93965 \\
\hline Argentína & 1 & 2,44746 & 5 & 1,7986 \\
\hline Banglades & 3 & 1,87772 & 3 & 1,15093 \\
\hline Benin & 3 & 2,39118 & 1 & 1,5487 \\
\hline Bissau-Guinea & 3 & 2,90817 & 1 & 2,11259 \\
\hline Bolívia & 4 & 1,68132 & 3 & 0,96506 \\
\hline Brazília & 1 & 3,30171 & 5 & 2,42353 \\
\hline Burkina Faso & 3 & 2,35007 & 3 & 1,34334 \\
\hline Burundi & 3 & 2,23343 & 3 & 2,48009 \\
\hline Chile & 4 & 2,83993 & 3 & 2,35353 \\
\hline Comore-szigetek & 3 & 2,99007 & 4 & 1,25144 \\
\hline Costa Rica & 4 & 2,27854 & 3 & 2,02136 \\
\hline Csád & 3 & 0,78793 & 3 & 1,35907 \\
\hline Ecuador & 4 & 2,21141 & 3 & 1,30721 \\
\hline Egyiptom & 4 & 2,34849 & 3 & 1,30151 \\
\hline El Salvador & 4 & 1,77421 & 3 & 1,03304 \\
\hline Elefántcsontpart & 4 & 2,33135 & 1 & 1,08332 \\
\hline Etiópia & 3 & 2,2627 & 3 & 1,31932 \\
\hline Fidzsi & 4 & 2,19183 & 4 & 1,65746 \\
\hline Fülöp-szigetek & 4 & 3,10411 & 3 & 2,00124 \\
\hline Gabon & 4 & 5,26216 & 1 & 2,41542 \\
\hline Gambia & 3 & 2,79735 & 1 & 1,99198 \\
\hline Ghána & 3 & 1,53789 & 1 & 1,28146 \\
\hline Grenada & 4 & 4,84999 & 4 & 1,74914 \\
\hline Guatemala & 4 & 1,98614 & 3 & 1,55069 \\
\hline Guyana & 4 & 2,08791 & 3 & 1,16658 \\
\hline Haiti & 3 & 1,71398 & 3 & 0,75563 \\
\hline Honduras & 4 & 2,06791 & 3 & 0,98165 \\
\hline Izrael & 1 & 3,85692 & 5 & 2,39707 \\
\hline Jamaica & 4 & 3,32661 & 2 & 1,86734 \\
\hline Jordánia & 4 & 3,81838 & 4 & 1,90685 \\
\hline Kamerun & 4 & 2,55873 & 1 & 0,68937 \\
\hline Kenya & 3 & 1,36606 & 3 & 0,78162 \\
\hline Kolumbia & 4 & 1,83275 & 3 & 1,22684 \\
\hline Kongó & 4 & 4,09942 & 1 & 1,90285 \\
\hline Kongói Dem, Közt, & 4 & 2,86042 & 1 & 1,34461 \\
\hline Közép-afrikai Köztársaság & 3 & 2,37894 & 1 & 1,19832 \\
\hline Laosz & 3 & 3,11799 & 3 & 2,45219 \\
\hline Libanon & 4 & 3,29422 & 4 & 1,4405 \\
\hline
\end{tabular}




\begin{tabular}{|c|c|c|c|c|}
\hline Libéria & 4 & 5,67022 & 1 & 3,31012 \\
\hline Madagaszkár & 3 & 1,5322 & 1 & 1,05148 \\
\hline Malajzia & 4 & 2,54515 & 3 & 1,78028 \\
\hline Malawi & 3 & 2,09131 & 3 & 1,68007 \\
\hline Mali & 3 & 3,03492 & 3 & 3,03671 \\
\hline Marokkó & 4 & 2,89916 & 1 & 1,65699 \\
\hline Mauritánia & 3 & 3,23697 & 1 & 1,52363 \\
\hline Mauritius & 4 & 1,93673 & 1 & 1,47442 \\
\hline Mozambik & 3 & 2,67236 & 3 & 2,10174 \\
\hline Nicaragua & 4 & 2,23308 & 3 & 1,87548 \\
\hline Niger & 3 & 1,48115 & 1 & 1,87626 \\
\hline Nigéria & 1 & 4,39629 & 5 & 3,20473 \\
\hline Pakisztán & 3 & 1,94255 & 3 & 0,8622 \\
\hline Panama & 2 & 1,7315 & 2 & 0,92269 \\
\hline Pápua Új-Guinea & 4 & 3,46238 & 3 & 1,57703 \\
\hline Paraguay & 4 & 1,60763 & 3 & 0,63665 \\
\hline Peru & 4 & 1,92272 & 3 & 1,57108 \\
\hline Ruanda & 3 & 1,19168 & 3 & 1,59798 \\
\hline Sao Tome és Principe & 4 & 3,7798 & 1 & 1,27616 \\
\hline Seychelle-szigetek & 2 & 4,1276 & 2 & 2,30241 \\
\hline Sierra Leone & 3 & 2,26684 & 1 & 1,48481 \\
\hline Sri Lanka & 4 & 2,45507 & 3 & 0,64325 \\
\hline Suriname & 4 & 3,03095 & 3 & 2,17243 \\
\hline Szamoa & 4 & 2,99998 & 3 & 1,96714 \\
\hline Szenegál & 4 & 2,33012 & 1 & 0,85447 \\
\hline Szingapúr & 2 & 3,6143 & 2 & 2,40473 \\
\hline Szíria & 4 & 1,63856 & 4 & 1,36473 \\
\hline Szomália & 3 & 1,83532 & 3 & 1,74693 \\
\hline Szudán & 3 & 1,6284 & 3 & 1,19294 \\
\hline Tanzánia & 3 & 1,32336 & 3 & 1,01035 \\
\hline Thaiföld & 4 & 2,4314 & 3 & 1,02734 \\
\hline Togo & 3 & 2,86262 & 1 & 1,2443 \\
\hline Trinidad és Tobago & 2 & 3,37874 & 2 & 1,96992 \\
\hline Tunézia & 4 & 2,27975 & 1 & 1,16867 \\
\hline Uganda & 3 & 1,53646 & 3 & 2,13963 \\
\hline Új-Kaledónia & 4 & 6,51102 & 1 & 2,31675 \\
\hline Uruguay & 4 & 2,39136 & 3 & 1,93582 \\
\hline Vanuatu & 4 & 3,28192 & 4 & 1,59982 \\
\hline Zambia & 4 & 3,08279 & 1 & 1,75369 \\
\hline Zöldfoki-szigetek & 4 & 3,67995 & 4 & 1,21293 \\
\hline
\end{tabular}

Megjegyzés: a klaszterszámok az eredeti, SPSS-output klaszterszámait takarják. A kiemelt országok ACPországok.

Forrás: saját számítás 


\section{SZÁMÚ MELLÉKLET: AZ ORSZÁGOK KLASZTERTAGSÁGA A LOMÉI EGYEZMÉNYEK UTÁN}

\begin{tabular}{|c|c|c|c|c|c|}
\hline Ország & Klaszter & Távolság & Ország & Klaszter & Távolság \\
\hline Angola & 1 & 1.2914 & Libéria & 2 & 2.21041 \\
\hline Argentína & 3 & 1.99474 & Madagaszkár & 2 & 0.73759 \\
\hline Banglades & 2 & 0.99919 & Malajzia & 3 & 1.74897 \\
\hline Benin & 2 & 0.60452 & Malawi & 2 & 1.09523 \\
\hline Bissau-Guinea & 2 & 1.56773 & Mali & 2 & 1.46776 \\
\hline Bolívia & 4 & 0.93203 & Marokkó & 5 & 2.78787 \\
\hline Brazília & 3 & 1.88606 & Mauritánia & 5 & 1.6104 \\
\hline Burkina Faso & 2 & 1.56787 & Mauritius & 4 & 1.48253 \\
\hline Burundi & 2 & 1.15084 & Mozambik & 4 & 2.0294 \\
\hline Chile & 4 & 1.68923 & Nicaragua & 4 & 1.62337 \\
\hline Comore-szigetek & 2 & 0.87973 & Niger & 2 & 0.81459 \\
\hline Costa Rica & 4 & 1.0903 & Nigéria & 2 & 2.07665 \\
\hline Csád & 1 & 2.98066 & Pakisztán & 2 & 1.43601 \\
\hline Ecuador & 4 & 0.64769 & Panama & 4 & 1.37943 \\
\hline Egyiptom & 4 & 1.96723 & Pápua Új-Guinea & 1 & 2.14426 \\
\hline El Salvador & 4 & 0.97724 & Paraguay & 4 & 0.92814 \\
\hline Elefántcsontpart & 1 & 1.99349 & Peru & 4 & 1.28523 \\
\hline Etiópia & 2 & 0.99237 & Ruanda & 2 & 0.90262 \\
\hline Fidzsi & 4 & 1.18181 & Sao Tome és P. & 5 & 1.80179 \\
\hline Fülöp-szigetek & 4 & 1.71574 & Seychelle-szigetek & 5 & 1.11133 \\
\hline Gabon & 1 & 1.77474 & Sierra Leone & 2 & 2.06318 \\
\hline Gambia & 5 & 1.7733 & Sri Lanka & 4 & 0.61776 \\
\hline Ghána & 2 & 0.74603 & Suriname & 4 & 1.91439 \\
\hline Grenada & 5 & 2.72359 & Szamoa & 4 & 1.67082 \\
\hline Guatemala & 4 & 1.16156 & Szenegál & 2 & 1.14839 \\
\hline Guyana & 4 & 1.44916 & Szíria & 2 & 1.63226 \\
\hline Haiti & 4 & 1.88864 & Szomália & 2 & 1.99092 \\
\hline Honduras & 4 & 0.71228 & Szudán & 2 & 1.38999 \\
\hline Izrael & 3 & 1.46572 & Tanzánia & 2 & 0.59488 \\
\hline Jamaica & 4 & 1.41085 & Thaiföld & 3 & 1.56294 \\
\hline Jordánia & 4 & 1.76567 & Togo & 2 & 0.69583 \\
\hline Kamerun & 4 & 1.26101 & Trinidad és Tobago & 4 & 2.20245 \\
\hline Kenya & 2 & 0.77286 & Tunézia & 5 & 3.02612 \\
\hline Kolumbia & 4 & 0.68126 & Uganda & 2 & 0.95395 \\
\hline Kongó & 1 & 1.35733 & Új-Kaledónia & 5 & 2.11749 \\
\hline Kongói Dem, Közt, & 2 & 1.37102 & Uruguay & 4 & 1.04343 \\
\hline Közép-afrikai Közt. & 2 & 2.5592 & Vanuatu & 5 & 2.37839 \\
\hline Laosz & 2 & 1.35227 & Zambia & 4 & 0.97961 \\
\hline Libanon & 5 & 1.2663 & Zöldfoki-szigetek & 5 & 1.53453 \\
\hline
\end{tabular}




\section{SZÁMÚ MELLÉKLET: A GRAVITÁCIÓS MODELL ALAPJÁUL SZOLGÁLÓ ORSZÁGOK}

\begin{tabular}{lll} 
Afganisztán & Haiti & Nepál \\
Algéria & Honduras & Nicaragua \\
Angola & India & Niger \\
Argentína & Indonézia & Nigéria \\
Banglades & Irak & Pakisztán \\
Benin & Irán & Panama \\
Bhutan & Jamaica & Pápua Új-Guinea \\
Bissau-Guinea & Jemen & Paraguay \\
Bolívia & Jordánia & Peru \\
Botswana & Kambodzsa & Ruanda \\
Brazília & Kamerun & Sao Tome \& Principe \\
Burkina Faso & Kenya & Sierra Leone \\
Burundi & Kína & Sri Lanka \\
Chile & Kolumbia & Szenegál \\
Costa Rica & Kongó & Szíria \\
Dél-afrikai Köztársaság & Laosz & Szudán \\
Dominikai Köztársaság & Lesotho & Tanzánia \\
Ecuador & Libanon & Thaiföld \\
Egyiptom & Libéria & Togo \\
El Salvador & Madagaszkár & Tonga \\
Elefántcsontpart & Malajzia & Törökország \\
Eritrea & Malawi & Tunézia \\
Etiópia & Mali & Uganda \\
Fidzsi & Marokkó & Vietnám \\
Fülöp-szigetek & Mauritánia & Zambia \\
Gambia & Mexikó & Zimbabwe \\
Ghána & Mongólia & Zöldfoki-szigetek \\
Guatemala & Mozambik & \\
Guinea & Namíbia & \\
\hline & & \\
\hline & &
\end{tabular}

Megjegyzés: a kiemelt országok ACP-országok

Forrás: saját szerkesztés 


\section{SZÁMÚ MELLÉKLET: A REGRESSZIÓS TÁBLÁZATOK}

\section{$\underline{\text { 1. AZ ALAPMODELL }}$}

Modell összefoglalója

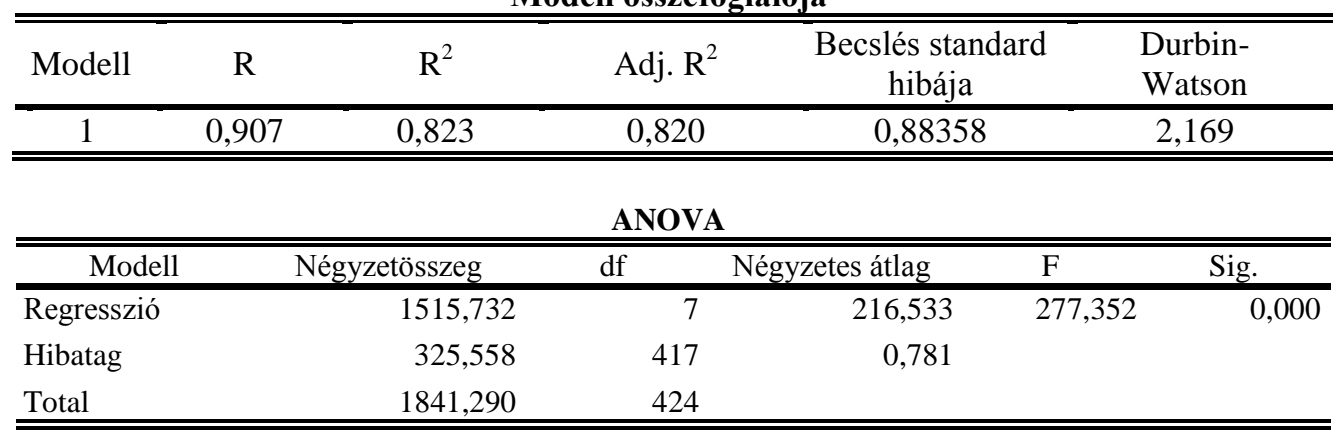

Regressziós együtthatók

\begin{tabular}{|c|c|c|c|c|c|c|c|}
\hline \multirow[t]{2}{*}{ Modell } & \multicolumn{3}{|r|}{$\begin{array}{c}\text { Standardizá } \\
\text { lt } \\
\text { együttható }\end{array}$} & \multirow[b]{2}{*}{$\mathrm{t}$} & \multirow[b]{2}{*}{ Sig. } & \multicolumn{2}{|c|}{ Kollinearitás } \\
\hline & B & Std. hiba & Beta & & & $\begin{array}{c}\text { Toleranc } \\
\mathrm{e}\end{array}$ & VIF \\
\hline Konstans & $-33,626$ & 1,463 & & $-22,986$ & 0,000 & & \\
\hline $\begin{array}{l}\text { paros gdp } \\
\text { szorzata }\end{array}$ & 0,897 & 0,026 & 0,856 & 33,972 & 0,000 & 0,668 & 1,497 \\
\hline $\begin{array}{l}\text { paros gdp/fo } \\
\text { szorzata }\end{array}$ & 0,088 & 0,050 & 0,046 & 1,773 & 0,077 & 0,635 & 1,575 \\
\hline In tavolsag & $-0,972$ & 0,096 & $-0,213$ & $-10,153$ & 0,000 & 0,959 & 1,042 \\
\hline 2007-e? & $-0,034$ & 0,136 & $-0,007$ & $-0,252$ & 0,801 & 0,623 & 1,604 \\
\hline 2008-e? & $-0,163$ & 0,137 & $-0,031$ & $-1,189$ & 0,235 & 0,614 & 1,629 \\
\hline 2009-e? & $-0,568$ & 0,138 & $-0,109$ & $-4,114$ & 0,000 & 0,601 & 1,663 \\
\hline 2010-e? & $-0,322$ & 0,137 & $-0,062$ & $-2,344$ & 0,020 & 0,610 & 1,640 \\
\hline
\end{tabular}

Hibatag statisztikája

\begin{tabular}{lrrrrr}
\hline \hline & Minimum & Maximum & \multicolumn{1}{c}{ Átlag } & \multicolumn{1}{c}{ Szórás } & N \\
\hline Becsült érték & 3,0287 & 12,5641 & 7,6323 & 1,89072 & 425 \\
Hibatag & $-5,49703$ & 4,28348 & 0,00000 & 0,87626 & 425 \\
Std. becsült érték & $-2,435$ & 2,608 & 0,000 & 1,000 & 425 \\
Std. hibatag & $-6,221$ & 4,848 & 0,000 & 0,992 & 425 \\
\hline \hline
\end{tabular}




\section{TELJES AFT}

Modell összefoglalója

\begin{tabular}{|c|c|c|c|c|c|c|}
\hline Modell & $\mathrm{R}$ & $\mathrm{R}^{2}$ & Adj. $\mathrm{R}^{2}$ & $\begin{array}{r}\text { Becslés sta } \\
\text { hibáj }\end{array}$ & & $\begin{array}{l}\text { Durbin- } \\
\text { Watson }\end{array}$ \\
\hline 1 & 0,912 & 0,832 & 0,829 & \multicolumn{2}{|c|}{0,86126} & 2,117 \\
\hline \multicolumn{7}{|c|}{ ANOVA } \\
\hline Modell & Nég & tösszeg & $\begin{array}{ll}\mathrm{df} & \text { Négyz }\end{array}$ & zetes átlag & $\overline{\mathrm{F}}$ & Sig. \\
\hline Regresszió & & 1532,714 & 8 & 191,589 & 258,287 & 0,000 \\
\hline Hibatag & & 308,576 & 416 & 0,742 & & \\
\hline Total & & 1841,290 & 424 & & & \\
\hline
\end{tabular}

Regressziós együtthatók

\begin{tabular}{|c|c|c|c|c|c|c|c|}
\hline \multirow[t]{2}{*}{$\overline{\text { Modell }}$} & \multicolumn{2}{|c|}{$\begin{array}{l}\text { Nem standardizált } \\
\text { együttható }\end{array}$} & \multirow{2}{*}{$\begin{array}{c}\begin{array}{c}\text { Standardizált } \\
\text { együttható }\end{array} \\
\text { Beta }\end{array}$} & \multirow[b]{2}{*}{$\mathrm{t}$} & \multirow[b]{2}{*}{ Sig. } & \multicolumn{2}{|c|}{ Kollinearitás } \\
\hline & $\mathrm{B}$ & Std. hiba & & & & Tolerance & VIF \\
\hline (Constant) & $-32,986$ & 1,432 & & $-23,032$ & 0,000 & & \\
\hline paros gdp szorzata & 0,814 & 0,031 & 0,777 & 26,215 & 0,000 & 0,459 & 2,179 \\
\hline paros gdp/fo szorzata & 0,209 & 0,055 & 0,108 & 3,816 & 0,000 & 0,501 & 1,998 \\
\hline ln tavolsag & $-0,894$ & 0,095 & $-0,196$ & $-9,429$ & 0,000 & 0,931 & 1,075 \\
\hline 2007-e? & $-0,009$ & 0,132 & $-0,002$ & $-0,071$ & 0,943 & 0,622 & 1,607 \\
\hline 2008-e? & $-0,196$ & 0,134 & $-0,038$ & $-1,466$ & 0,143 & 0,612 & 1,634 \\
\hline 2009-e? & $-0,628$ & 0,135 & $-0,121$ & $-4,644$ & 0,000 & 0,596 & 1,677 \\
\hline 2010-e? & $-0,370$ & 0,134 & $-0,071$ & $-2,759$ & 0,006 & 0,606 & 1,649 \\
\hline Teljes AFT, ln & 0,112 & 0,023 & 0,121 & 4,785 & 0,000 & 0,629 & 1,591 \\
\hline
\end{tabular}

Hibatag statisztikája

\begin{tabular}{lrrrrr}
\hline \hline & Minimum & Maximum & \multicolumn{1}{c}{ Átlag } & \multicolumn{1}{c}{ Szórás } & \multicolumn{1}{c}{ N } \\
\hline Becsült érték & 2,5163 & 12,6018 & 7,6323 & 1,90129 & 425 \\
Hibatag & $-5,48340$ & 3,78931 & 0,00000 & 0,85310 & 425 \\
Std. becsült érték & $-2,691$ & 2,614 & 0,000 & 1,000 & 425 \\
Std. hibatag & $-6,367$ & 4,400 & 0,000 & 0,991 & 425 \\
\hline \hline
\end{tabular}




\section{TELJES AFT + ACP, LDC, OIL DUMMY}

Modell összefoglalója

\begin{tabular}{|c|c|c|c|c|c|c|}
\hline Modell & $\mathrm{R}$ & $\mathrm{R}^{2}$ & Adj. $R^{2}$ & $\begin{array}{c}\text { Becslés standard } \\
\text { hibája }\end{array}$ & \multicolumn{2}{|c|}{$\begin{array}{l}\text { Durbin- } \\
\text { Watson }\end{array}$} \\
\hline 1 & 0,920 & 0,847 & 0,843 & 0,82519 & & 2,117 \\
\hline \multicolumn{7}{|c|}{ ANOVA } \\
\hline \multicolumn{2}{|c|}{ Modell } & Négyzetösszeg & df & Négyzetes átlag & $\bar{F}$ & Sig. \\
\hline & & 1560,065 & 11 & 141,824 & 208,279 & 0,000 \\
\hline & & 281,225 & 413 & 0,681 & & \\
\hline & & 1841,290 & 424 & & & \\
\hline
\end{tabular}

Hibatag statisztikája

\begin{tabular}{lrrrrr}
\hline \hline & Minimum & Maximum & \multicolumn{1}{c}{ Átlag } & \multicolumn{1}{c}{ Szórás } & \multicolumn{1}{c}{ N } \\
\hline Becsült érték & 2,6257 & 12,5693 & 7,6323 & 1,91818 & 425 \\
Hibatag & $-5,50897$ & 3,93550 & 0,00000 & 0,81441 & 425 \\
Std. becsült érték & $-2,610$ & 2,574 & 0,000 & 1,000 & 425 \\
Std. hibatag & $-6,676$ & 4,769 & 0,000 & 0,987 & 425 \\
\hline \hline
\end{tabular}

Regressziós együtthatók

\begin{tabular}{|c|c|c|c|c|c|c|c|}
\hline \multirow[t]{2}{*}{ Modell } & \multicolumn{2}{|c|}{$\begin{array}{c}\text { Nem standardizált } \\
\text { együttható }\end{array}$} & \multirow{2}{*}{$\begin{array}{c}\begin{array}{c}\text { Standardizált } \\
\text { együttható }\end{array} \\
\text { Beta }\end{array}$} & \multirow[b]{2}{*}{$\mathrm{t}$} & \multirow[b]{2}{*}{ Sig. } & \multicolumn{2}{|c|}{ Kollinearitás } \\
\hline & $\mathrm{B}$ & Std. hiba & & & & Tolerance & VIF \\
\hline (Constant) & $-33,780$ & 1,865 & & $-18,113$ & 0,000 & & \\
\hline paros gdp szorzata & 0,832 & 0,032 & 0,794 & 25,614 & 0,000 & 0,385 & 2,597 \\
\hline $\begin{array}{l}\text { paros gdp/fo } \\
\text { szorzata }\end{array}$ & 0,184 & 0,065 & 0,095 & 2,822 & 0,005 & 0,325 & 3,081 \\
\hline In tavolsag & $-0,903$ & 0,093 & $-0,198$ & $-9,750$ & 0,000 & 0,894 & 1,119 \\
\hline 2007-e? & $-0,003$ & 0,127 & $-0,001$ & $-0,027$ & 0,979 & 0,620 & 1,613 \\
\hline 2008-e? & $-0,197$ & 0,130 & $-0,038$ & $-1,517$ & 0,130 & 0,595 & 1,680 \\
\hline 2009-e? & $-0,632$ & 0,133 & $-0,121$ & $-4,738$ & 0,000 & 0,563 & 1,775 \\
\hline 2010-e? & $-0,374$ & 0,131 & $-0,072$ & $-2,856$ & 0,005 & 0,584 & 1,714 \\
\hline Teljes AFT, ln & 0,131 & 0,023 & 0,142 & 5,760 & 0,000 & 0,606 & 1,650 \\
\hline ACP-ország-e & 0,565 & 0,102 & 0,136 & 5,557 & 0,000 & 0,620 & 1,614 \\
\hline olajexportor orszag & 0,186 & 0,116 & 0,034 & 1,596 & 0,111 & 0,814 & 1,229 \\
\hline LDC & $-0,372$ & 0,129 & $-0,088$ & $-2,887$ & 0,004 & 0,401 & 2,493 \\
\hline
\end{tabular}




\section{AFT*ACP INTERAKCIÓ}

Modell összefoglalója

\begin{tabular}{lccrrr}
\hline \hline Modell & $\mathrm{R}$ & $\mathrm{R}^{2}$ & Adj. $\mathrm{R}^{2}$ & $\begin{array}{c}\text { Becslés standard } \\
\text { hibája }\end{array}$ & $\begin{array}{l}\text { Durbin- } \\
\text { Watson }\end{array}$ \\
\hline 1 & 0,922 & 0,850 & 0,846 & 0,81857 & 2,102 \\
\hline \hline
\end{tabular}

ANOVA

\begin{tabular}{llrrrrr}
\hline \hline & Modell & Négyzetösszeg & df & Négyzetes átlag & F & Sig. \\
\hline 1 & Regresszió & 1564,554 & 11 & 142,232 & 212,267 & 0,000 \\
& Hibatag & 276,736 & 413 & 0,670 & & \\
Total & 1841,290 & 424 & & & \\
\hline \hline
\end{tabular}

Hibatag statisztikája

\begin{tabular}{lrrrrr}
\hline \hline & Minimum & Maximum & \multicolumn{1}{c}{ Átlag } & \multicolumn{1}{c}{ Szórás } & N \\
\hline Becsült érték & 2,3618 & 12,5307 & 7,6323 & 1,92093 & 425 \\
Hibatag & $-5,46146$ & 3,95410 & 0,00000 & 0,80789 & 425 \\
Std. becsült érték & $-2,744$ & 2,550 & 0,000 & 1,000 & 425 \\
Std. hibatag & $-6,672$ & 4,830 & 0,000 & 0,987 & 425 \\
\hline \hline
\end{tabular}

Regressziós együtthatók

\begin{tabular}{|c|c|c|c|c|c|c|c|}
\hline \multirow[t]{2}{*}{ Modell } & \multicolumn{2}{|c|}{$\begin{array}{c}\text { Nem standardizált } \\
\text { együttható }\end{array}$} & \multirow{2}{*}{$\begin{array}{c}\begin{array}{c}\text { Standardiz } \\
\text { ált } \\
\text { együttható }\end{array} \\
\text { Beta }\end{array}$} & \multirow[b]{2}{*}{$\mathrm{t}$} & \multirow[b]{2}{*}{ Sig. } & \multicolumn{2}{|c|}{ Kollinearitás } \\
\hline & $\mathrm{B}$ & Std. hiba & & & & $\begin{array}{l}\text { Toleran } \\
\text { ce }\end{array}$ & VIF \\
\hline (Constant) & $-33,348$ & 1,735 & & $-19,222$ & 0,000 & & \\
\hline paros gdp szorzata & 0,838 & 0,031 & 0,800 & 26,830 & 0,000 & 0,410 & 2,441 \\
\hline paros gdp/fo szorzata & 0,154 & 0,064 & 0,080 & 2,402 & 0,017 & 0,331 & 3,022 \\
\hline ln tavolsag & $-0,893$ & 0,091 & $-0,196$ & $-9,851$ & 0,000 & 0,919 & 1,088 \\
\hline 2007-e? & 0,002 & 0,126 & 0,000 & 0,013 & 0,989 & 0,620 & 1,613 \\
\hline 2008-e? & $-0,182$ & 0,129 & $-0,035$ & $-1,413$ & 0,158 & 0,596 & 1,677 \\
\hline 2009-e? & $-0,609$ & 0,132 & $-0,117$ & $-4,612$ & 0,000 & 0,566 & 1,767 \\
\hline 2010-e? & $-0,359$ & 0,130 & $-0,069$ & $-2,763$ & 0,006 & 0,585 & 1,709 \\
\hline Teljes AFT, ln & 0,101 & 0,022 & 0,110 & 4,495 & 0,000 & 0,612 & 1,633 \\
\hline $\mathrm{AfT}^{*} \mathrm{ACP}$ & 0,061 & 0,010 & 0,142 & 6,064 & 0,000 & 0,662 & 1,511 \\
\hline AFT*LDC & $-0,049$ & 0,013 & $-0,113$ & $-3,796$ & 0,000 & 0,409 & 2,448 \\
\hline AFT*olaj & 0,011 & 0,011 & 0,020 & 0,937 & 0,349 & 0,828 & 1,207 \\
\hline
\end{tabular}




\section{AFT RÉSZTERÜLETEI}

Modell összefoglalója

\begin{tabular}{|c|c|c|c|c|c|c|}
\hline Modell & $\mathrm{R}$ & $\mathrm{R}^{2}$ & Adj. $\mathrm{R}^{2}$ & \multicolumn{2}{|c|}{$\begin{array}{c}\text { Becslés standard } \\
\text { hibája }\end{array}$} & $\begin{array}{l}\text { Durbin- } \\
\text { Watson }\end{array}$ \\
\hline 1 & 0,912 & 0,831 & 0,827 & 0,8 & & 2,129 \\
\hline \multicolumn{7}{|c|}{ ANOVA } \\
\hline & Modell & Négyzetösszeg & df & égyzetes átlag & $\mathrm{F}$ & Sig. \\
\hline \multirow[t]{3}{*}{1} & Regresszió & 1529,945 & 10 & 152,994 & 203,438 & 0,000 \\
\hline & Hibatag & 311,346 & 414 & 0,752 & & \\
\hline & Total & 1841,290 & 424 & & & \\
\hline
\end{tabular}

Regressziós együtthatók

\begin{tabular}{|c|c|c|c|c|c|c|c|}
\hline \multirow[t]{2}{*}{ Modell } & \multicolumn{2}{|c|}{$\begin{array}{c}\text { Nem standardizált } \\
\text { együttható }\end{array}$} & \multirow{2}{*}{$\begin{array}{c}\begin{array}{c}\text { Standardizál } \\
\text { t együttható }\end{array} \\
\text { Beta } \\
\end{array}$} & \multirow[b]{2}{*}{$\mathrm{t}$} & \multirow[b]{2}{*}{ Sig. } & \multicolumn{2}{|c|}{ Kollinearitás } \\
\hline & $\mathrm{B}$ & Std. hiba & & & & $\begin{array}{c}\text { Toleranc } \\
\mathrm{e}\end{array}$ & VIF \\
\hline (Constant) & $-32,643$ & 1.470 & & $-22,210$ & 0,000 & & \\
\hline paros gdp szorzata & 0,818 & 0,032 & 0,781 & 25,270 & 0,000 & 0,428 & 2,337 \\
\hline paros gdp/fo szorzata & 0,198 & 0,057 & 0,103 & 3,499 & 0,001 & 0,474 & 2,109 \\
\hline ln tavolsag & $-0,903$ & 0,097 & $-0,198$ & $-9,265$ & 0,000 & 0,892 & 1,121 \\
\hline 2007-e? & $-0,008$ & 0,134 & $-0,002$ & $-0,062$ & 0,951 & 0,620 & 1,612 \\
\hline 2008-e? & $-0,168$ & 0,135 & $-0,032$ & $-1,245$ & 0,214 & 0,610 & 1,639 \\
\hline 2009-e? & $-0,618$ & 0,136 & $-0,119$ & $-4,531$ & 0,000 & 0,595 & 1,679 \\
\hline 2010-e? & $-0,357$ & 0,135 & $-0,069$ & $-2,641$ & 0,009 & 0,605 & 1,652 \\
\hline $\begin{array}{l}\text { Economic infrastructure, } \\
\text { ezer dollar, ln }\end{array}$ & 0,042 & 0,015 & 0,069 & 2,742 & 0,006 & 0,652 & 1,534 \\
\hline BPC, ezer dollar, ln & 0,050 & 0,024 & 0,057 & 2,065 & 0,040 & 0,530 & 1,887 \\
\hline TPR, ezer dollar, ln & 0,003 & 0,016 & 0,004 & 0,173 & 0,863 & 0,816 & 1,226 \\
\hline
\end{tabular}

Hibatag statisztikája

\begin{tabular}{|c|c|c|c|c|c|}
\hline & Minimum & Maximum & Átlag & Szórás & $\mathrm{N}$ \\
\hline Becsült érték & 2,7889 & 12,6282 & 7,6323 & 1,89957 & 425 \\
\hline Hibatag & $-5,42878$ & 3,87155 & 0,00000 & 0,85692 & 425 \\
\hline Std. becsült érték & $-2,550$ & 2,630 & 0,000 & 1,000 & 425 \\
\hline Std. hibatag & $-6,260$ & 4,464 & 0,000 & 0,988 & 425 \\
\hline
\end{tabular}




\section{AFT RÉSZTERÜLETEI + ACP, OIL, LDC DUMMY}

Modell összefoglalója

\begin{tabular}{llrrrr}
\hline \hline Modell & $\mathrm{R}$ & $\mathrm{R}^{2}$ & Adj. $\mathrm{R}^{2}$ & $\begin{array}{c}\text { Becslés standard } \\
\text { hibája }\end{array}$ & $\begin{array}{l}\text { Durbin- } \\
\text { Watson }\end{array}$ \\
\hline 1 & 0,920 & 0,846 & 0,841 & 0,83096 & 2,141 \\
\hline \hline
\end{tabular}

ANOVA

\begin{tabular}{lrrrrr}
\hline \hline Modell & Négyzetösszeg & df & $\begin{array}{c}\text { Négyzetes } \\
\text { átlag }\end{array}$ & \multicolumn{1}{c}{ F } & \multicolumn{1}{c}{ Sig. } \\
\hline Regresszió & 1557,497 & 13 & 119,807 & 173,510 & 0,000 \\
Hibatag & 283,793 & 411 & 0,690 & & \\
Total & 1841,290 & 424 & & & \\
\hline \hline
\end{tabular}

Regressziós együtthatók

\begin{tabular}{|c|c|c|c|c|c|c|c|}
\hline & & esszios & gyutthatok & & & & \\
\hline \multirow[t]{2}{*}{ Modell } & \multicolumn{2}{|c|}{$\begin{array}{c}\text { Nem standardizált } \\
\text { együttható }\end{array}$} & \multirow{2}{*}{$\begin{array}{c}\begin{array}{c}\text { Standardizált } \\
\text { együttható }\end{array} \\
\text { Beta }\end{array}$} & \multirow[b]{2}{*}{$\mathrm{t}$} & \multirow[b]{2}{*}{ Sig. } & \multicolumn{2}{|c|}{ Kollinearitás } \\
\hline & $\mathrm{B}$ & Std. hiba & & & & Tolerance & VIF \\
\hline (Constant) & $-33,311$ & 1.903 & & $-17,508$ & 0,000 & & \\
\hline paros gdp szorzata & 0,837 & 0,034 & 0,798 & 24,836 & 0,000 & 0,363 & 2,754 \\
\hline paros gdp/fo szorzata & 0,165 & 0,067 & 0,085 & 2,465 & 0,014 & 0,313 & 3,190 \\
\hline ln tavolsag & $-0,907$ & 0,095 & $-0,199$ & $-9,549$ & 0,000 & 0,862 & 1,160 \\
\hline 2007-e? & $-0,003$ & 0,128 & $-0,001$ & $-0,027$ & 0,979 & 0,618 & 1,619 \\
\hline 2008-e? & $-0,161$ & 0,131 & $-0,031$ & $-1,233$ & 0,218 & 0,593 & 1,686 \\
\hline 2009-e? & $-0,619$ & 0,134 & $-0,119$ & $-4,607$ & 0,000 & 0,562 & 1,780 \\
\hline 2010-e? & $-0,358$ & 0,132 & $-0,069$ & $-2,713$ & 0,007 & 0,582 & 1,719 \\
\hline $\begin{array}{l}\text { Economic infrastructure, } \\
\text { ezer dollar, ln }\end{array}$ & 0,053 & 0,015 & 0,086 & 3,577 & 0,000 & 0,643 & 1,555 \\
\hline BPC, ezer dollar, ln & 0,060 & 0,023 & 0,069 & 2,581 & 0,010 & 0,519 & 1,926 \\
\hline TPR, ezer dollar, ln & $-0,004$ & 0,015 & $-0,006$ & $-0,267$ & 0,790 & 0,808 & 1,237 \\
\hline ACP-ország-e & 0,569 & 0,103 & 0,137 & 5,524 & 0,000 & 0,613 & 1,631 \\
\hline olajexportor orszag & 0,162 & 0,117 & 0,030 & 1,385 & 0,167 & 0,818 & 1,223 \\
\hline LDC & $-0,398$ & 0,130 & $-0,094$ & $-3,054$ & 0,002 & 0,399 & 2,505 \\
\hline
\end{tabular}

Hibatag statisztikája

\begin{tabular}{lrrrrr}
\hline \hline & \multicolumn{1}{c}{ Minimum } & \multicolumn{1}{c}{ Maximum } & \multicolumn{1}{c}{ Átlag } & \multicolumn{1}{c}{ Szórás } & \multicolumn{1}{c}{ } \\
\hline Becsült érték & 2,9452 & 12,5844 & 7,6323 & 1,91660 & 425 \\
Hibatag & $-5,40702$ & 4,01948 & 0,00000 & 0,81812 & 425 \\
Std. becsült érték & $-2,446$ & 2,584 & 0,000 & 1,000 & 425 \\
Std. hibatag & $-6,507$ & 4,837 & 0,000 & 0,985 & 425 \\
\hline \hline
\end{tabular}




\section{NEM ACP-ORSZÁGOK}

Modell összefoglalója

\begin{tabular}{llrrrr}
\hline \hline Modell & $\mathrm{R}$ & $\mathrm{R}^{2}$ & Adj. $\mathrm{R}^{2}$ & $\begin{array}{c}\text { Becslés standard } \\
\text { hibája }\end{array}$ & $\begin{array}{l}\text { Durbin- } \\
\text { Watson }\end{array}$ \\
\hline 1 & 0,920 & 0,846 & 0,838 & 0,80521 & 2,151 \\
\hline \hline
\end{tabular}

ANOVA

\begin{tabular}{llrrrrr}
\hline \hline Modell & Négyzetösszeg & df & Négyzetes átlag & F & Sig. \\
\hline 1 & Regresszió & 706,772 & 10 & 70,677 & 109,008 & 0,000 \\
& Hibatag & 129,024 & 199 & 0,648 & & \\
Total & 835,796 & 209 & & & \\
\hline \hline
\end{tabular}

Regressziós együtthatók

\begin{tabular}{|c|c|c|c|c|c|c|c|}
\hline \multirow[t]{2}{*}{ Modell } & \multicolumn{2}{|c|}{$\begin{array}{c}\text { Nem standardizált } \\
\text { együttható }\end{array}$} & \multirow{2}{*}{$\begin{array}{c}\begin{array}{c}\text { Standardizál } \\
\text { t együttható }\end{array} \\
\text { Beta }\end{array}$} & \multirow[b]{2}{*}{$\mathrm{t}$} & \multirow[b]{2}{*}{ Sig. } & \multicolumn{2}{|c|}{ Kollinearitás } \\
\hline & $\mathrm{B}$ & Std. hiba & & & & $\begin{array}{c}\text { Toleranc } \\
\mathrm{e}\end{array}$ & VIF \\
\hline (Constant) & $-39,544$ & 2,010 & & $-19,677$ & 0,000 & & \\
\hline paros gdp szorzata & 0,924 & 0,041 & 0,816 & 22,404 & 0,000 & 0,585 & 1,710 \\
\hline paros gdp/fo szorzata & 0,233 & 0,084 & 0,107 & 2,768 & 0,006 & 0,515 & 1,943 \\
\hline ln tavolsag & $-0,832$ & 0,103 & $-0,235$ & $-8,067$ & 0,000 & 0,912 & 1,097 \\
\hline 2007-e? & $-0,080$ & 0,177 & $-0,016$ & $-0,454$ & 0,651 & 0,615 & 1,625 \\
\hline 2008-e? & $-0,271$ & 0,179 & $-0,054$ & $-1,517$ & 0,131 & 0,604 & 1,655 \\
\hline 2009-e? & $-0,800$ & 0,184 & $-0,160$ & $-4,349$ & 0,000 & 0,570 & 1,755 \\
\hline 2010-e? & $-0,572$ & 0,181 & $-0,115$ & $-3,158$ & 0,002 & 0,587 & 1,702 \\
\hline $\begin{array}{l}\text { Economic infrastructure, } \\
\text { ezer dollar, } \ln \end{array}$ & 0,066 & 0,024 & 0,101 & 2,724 & 0,007 & 0,563 & 1,777 \\
\hline BPC, ezer dollar, ln & 0,015 & 0,035 & 0,015 & 0,436 & 0,664 & 0,620 & 1,612 \\
\hline TPR, ezer dollar, ln & $-0,031$ & 0,022 & $-0,045$ & $-1,418$ & 0,158 & 0,785 & 1,274 \\
\hline
\end{tabular}

Hibatag statisztikája

\begin{tabular}{lrrrrr}
\hline \hline & Minimum & Maximum & \multicolumn{1}{c}{ Átlag } & \multicolumn{1}{c}{ Szórás } & \multicolumn{1}{c}{ N } \\
\hline Becsült érték & 4,6832 & 12.6730 & 8,5594 & 1,83894 & 210 \\
Hibatag & $-5,22945$ & 3.69016 & 0,00000 & 0,78571 & 210 \\
Std. becsült érték & $-2,108$ & 2.237 & 0,000 & 1,000 & 210 \\
Std. hibatag & $-6,495$ & 4.583 & 0,000 & 0,976 & 210 \\
\hline \hline
\end{tabular}




\section{ACP-ORSZÁGOK}

Modell összefoglalója

\begin{tabular}{|c|c|c|c|c|}
\hline Modell & $\mathrm{R}$ & $\mathrm{R}^{2}$ & Adj. $\mathrm{R}^{2}$ & $\begin{array}{l}\text { Becslés standard } \\
\text { hibája }\end{array}$ \\
\hline 0,877 & 0,768 & 0,756 & 0,860 & 1,955 \\
\hline
\end{tabular}

ANOVA

\begin{tabular}{lccr}
\hline \hline Modell & $\begin{array}{c}\text { Négyzetös } \\
\text { szeg }\end{array}$ & df & \multicolumn{2}{c}{$\begin{array}{c}\text { Négyzetes } \\
\text { átlag }\end{array}$} \\
\hline Regresszió & 495,650 & 10 & 49,565 \\
\hline Hibatag & 149,504 & 202 & 0,740 \\
\hline \hline
\end{tabular}

Regressziós együtthatók

\begin{tabular}{lrrrrr}
\hline Modell & \multicolumn{2}{c}{$\begin{array}{c}\text { Rem standardizált } \\
\text { együttható }\end{array}$} & $\begin{array}{c}\text { Standardizált } \\
\text { együttható }\end{array}$ & t & Sig. \\
\cline { 2 - 6 } & \multicolumn{1}{c}{ B } & Std. hiba & Beta & & \\
\hline 2007-e? & 0,011 & 0,163 & 0,003 & 0,068 & 0,946 \\
2008-e? & $-0,199$ & 0,166 & $-0,053$ & $-1,196$ & 0,233 \\
2009-e? & $-0,602$ & 0,168 & $-0,160$ & $-3,576$ & 0,000 \\
2010-e? & $-0,281$ & 0,166 & $-0,075$ & $-1,699$ & 0,091 \\
paros gdp szorzata & 0,736 & 0,053 & 0,649 & 13,789 & 0,000 \\
paros gdp/fo szorzata & 0,376 & 0,084 & 0,214 & 4,504 & 0,000 \\
ln tavolsag & $-1,022$ & 0,237 & $-0,184$ & $-4,322$ & 0,000 \\
Economic infrastructure, & 0,035 & 0,020 & 0,071 & 1,755 & 0,081 \\
ezer dollar, ln & 0,125 & 0,035 & 0,187 & 3,534 & 0,001 \\
BPC, ezer dollar, ln & 0,020 & 0,022 & 0,035 & 0,916 & 0,361 \\
TPR, ezer dollar, ln & $-30,754$ & 2,896 & & $-10,618$ & 0,000 \\
(Constant) & Cochrane-Orcutt becsléssel. & &
\end{tabular}

Cochrane-Orcutt becsléssel. 


\section{NEM ACP-ORSZÁG + ACP, LDC, OIL DUMMY}

Modell összefoglalója

\begin{tabular}{llrrrr}
\hline \hline Modell & $\mathrm{R}$ & $\mathrm{R}^{2}$ & Adj. $\mathrm{R}^{2}$ & $\begin{array}{c}\text { Becslés standard } \\
\text { hibája }\end{array}$ & $\begin{array}{l}\text { Durbin- } \\
\text { Watson }\end{array}$ \\
\hline 1 & 0,924 & 0,855 & 0,846 & 0,78535 & 1,960 \\
\hline \hline
\end{tabular}

ANOVA

\begin{tabular}{llrrrrr}
\hline \hline & Modell & Négyzetösszeg & df & Négyzetes átlag & F & \multicolumn{1}{c}{ Sig. } \\
\hline 1 & Regresszió & 714,291 & 12 & 59,524 & 96,509 & 0,000 \\
& Hibatag & 121,505 & 197 & 0,617 & & \\
Total & 835,796 & 209 & & & \\
\hline \hline
\end{tabular}

Regressziós együtthatók

\begin{tabular}{|c|c|c|c|c|c|c|c|}
\hline & \multicolumn{2}{|c|}{$\begin{array}{l}\text { Nem standardizált } \\
\text { együttható }\end{array}$} & \multirow{2}{*}{$\begin{array}{c}\begin{array}{c}\text { Standardizált } \\
\text { együttható }\end{array} \\
\text { Beta }\end{array}$} & \multirow[b]{2}{*}{$\mathrm{t}$} & \multirow[b]{2}{*}{ Sig. } & \multicolumn{2}{|c|}{ Kollinearitás } \\
\hline & $\mathrm{B}$ & Std. hiba & & & & Tolerance & VIF \\
\hline (Constant) & $-35,186$ & 2,325 & & $-15,135$ & 0,000 & & \\
\hline paros gdp szorzata & 0,895 & 0,042 & 0,790 & 21,324 & 0,000 & 0,537 & 1,862 \\
\hline paros gdp/fo szorzata & 0,079 & 0,095 & 0,036 & 0,832 & 0,406 & 0,385 & 2,597 \\
\hline ln tavolsag & $-0,803$ & 0,102 & $-0,227$ & $-7,881$ & 0,000 & 0,888 & 1,126 \\
\hline 2007-e? & $-0,055$ & 0,173 & $-0,011$ & $-0,320$ & 0,750 & 0,614 & 1,628 \\
\hline 2008-e? & $-0,184$ & 0,176 & $-0,037$ & $-1,044$ & 0,298 & 0,592 & 1,690 \\
\hline 2009-e? & $-0,672$ & 0,183 & $-0,135$ & $-3,665$ & 0,000 & 0,546 & 1,832 \\
\hline 2010-e? & $-0,460$ & 0,180 & $-0,092$ & $-2,556$ & 0,011 & 0,568 & 1,762 \\
\hline $\begin{array}{l}\text { Economic infrastructure, } \\
\text { ezer dollar, ln }\end{array}$ & 0,079 & 0,024 & 0,121 & 3,308 & 0,001 & 0,548 & 1,826 \\
\hline BPC, ezer dollar, ln & $-0,016$ & 0,036 & $-0,016$ & $-0,452$ & 0,652 & 0,569 & 1,758 \\
\hline TPR, ezer dollar, ln & $-0,025$ & 0,021 & $-0,037$ & $-1,195$ & 0,234 & 0,779 & 1,284 \\
\hline olajexportor orszag & $-0,037$ & 0,134 & $-0,008$ & $-0,276$ & 0,783 & 0,842 & 1,188 \\
\hline LDC & $-0,707$ & 0,207 & $-0,132$ & $-3,418$ & 0,001 & 0,494 & 2,026 \\
\hline
\end{tabular}

Hibatag statisztikája

\begin{tabular}{lrrrrr}
\hline \hline & Minimum & Maximum & \multicolumn{1}{c}{ Átlag } & \multicolumn{1}{c}{ Szórás } & \multicolumn{1}{c}{ N } \\
\hline Becsült érték & 4,3389 & 12,6288 & 8,5594 & 1,84869 & 210 \\
Hibatag & $-5,16005$ & 3,67932 & 0,00000 & 0,76247 & 210 \\
Std. becsült érték & $-2,283$ & 2,201 & 0,000 & 1,000 & 210 \\
Std. hibatag & $-6,570$ & 4,685 & 0,000 & 0,971 & 210 \\
\hline \hline
\end{tabular}




\section{ACP-ORSZÁG + ACP, LDC, OIL DUMMY}

Modell összefoglalója

\begin{tabular}{|c|c|c|c|c|}
\hline Modell & $\mathrm{R}$ & $\mathrm{R}^{2}$ & Adj. $\mathrm{R}^{2}$ & $\begin{array}{c}\text { Becslés standard } \\
\text { hibája }\end{array}$ \\
\hline .892 & 0,796 & 0,783 & 0,823 & 1,916 \\
\hline
\end{tabular}

Cochrane-Orcutt becsléssel.

ANOVA

\begin{tabular}{llcr}
\hline \hline Modell & $\begin{array}{c}\text { Négyzetös } \\
\text { szeg }\end{array}$ & df & \multicolumn{2}{c}{$\begin{array}{c}\text { Négyzetes } \\
\text { átlag }\end{array}$} \\
\hline Regresszió & 529,726 & 12 & 44,144 \\
\hline Hibatag & 135,357 & 200 & 0,677 \\
\hline \hline
\end{tabular}

Cochrane-Orcutt becsléssel.

Regressziós együtthatók

\begin{tabular}{lrrrrr}
\hline \hline Modell & \multicolumn{2}{c}{$\begin{array}{c}\text { Nem standardizált } \\
\text { együttható }\end{array}$} & $\begin{array}{c}\text { Standardizált } \\
\text { együttható }\end{array}$ & \multicolumn{1}{c}{ t } & Sig. \\
\cline { 2 - 6 } & B & Std. hiba & Beta & & \\
\hline 2007-e? & 0,045 & 0,143 & 0,013 & 0,312 & 0,756 \\
2008-e? & $-0,125$ & 0,148 & $-0,036$ & $-0,840$ & 0,402 \\
2009-e? & $-0,496$ & 0,153 & $-0,142$ & $-3,247$ & 0,001 \\
2010-e? & $-0,195$ & 0,148 & $-0,056$ & $-1,321$ & 0,188 \\
paros gdp szorzata & 0,666 & 0,052 & 0,592 & 12,914 & 0,000 \\
paros gdp/fo szorzata & 0,251 & 0,091 & 0,142 & 2,748 & 0,007 \\
ln tavolsag & $-0,865$ & 0,237 & $-0,153$ & $-3,656$ & 0,000 \\
Economic infrastructure, & 0,043 & 0,018 & 0,089 & 2,344 & 0,020 \\
ezer dollar, ln & 0,141 & 0,033 & 0,209 & 4,248 & 0,000 \\
BPC, ezer dollar, ln & 0,023 & 0,021 & 0,041 & 1,128 & 0,261 \\
TPR, ezer dollar, ln & 0,844 & 0,225 & 0,138 & 3,750 & 0,000 \\
olajexportor orszag & $-0,294$ & 0,174 & $-0,084$ & $-1,693$ & 0,092 \\
LDC & $-26,471$ & 3,312 & & $-7,991$ & 0,000 \\
(Constant) & Cochrane-Orcuttbeck \\
\hline \hline
\end{tabular}

Cochrane-Orcutt becsléssel. 
6. SZÁMÚ MELLÉKLET: A REGRESSZIÓS TÁBLÁZATOK - KIUGRÓ ÉRTÉKEK NÉLKÜL

\section{ALAPMODELL}

Modell összefoglalója

\begin{tabular}{llrrrr}
\hline \hline Modell & $\mathrm{R}$ & $\mathrm{R}^{2}$ & Adj. $\mathrm{R}^{2}$ & $\begin{array}{c}\text { Becslés standard } \\
\text { hibája }\end{array}$ & $\begin{array}{c}\text { Durbin- } \\
\text { Watson }\end{array}$ \\
\hline 1 & 0,904 & 0,816 & 0,813 & 0,83950 & 2,182 \\
\hline \hline
\end{tabular}

ANOVA

\begin{tabular}{llrrrrr}
\hline \hline & Modell & Négyzetösszeg & df & Négyzetes átlag & \multicolumn{1}{c}{ F } & \multicolumn{1}{c}{ Sig. } \\
\hline 1 & Regresszió & 1225,540 & 7 & 175,077 & 248,423 & 0,000 \\
& Hibatag & 275,558 & 391 & 0,705 & & \\
Total & 1501,099 & 398 & & & \\
& & & & & & \\
\end{tabular}

Regressziós együtthatók

\begin{tabular}{|c|c|c|c|c|c|c|c|}
\hline \multirow[t]{3}{*}{ Modell } & & & \\
\hline & \multicolumn{2}{|c|}{$\begin{array}{c}\text { Nem standardizált } \\
\text { együttható }\end{array}$} & \multirow{2}{*}{$\begin{array}{c}\begin{array}{c}\text { lt } \\
\text { együttható }\end{array} \\
\text { Beta }\end{array}$} & \multirow[b]{2}{*}{$\mathrm{t}$} & \multirow[b]{2}{*}{ Sig. } & \multicolumn{2}{|c|}{ Kollinearitás } \\
\hline & B & Std. hiba & & & & $\begin{array}{c}\text { Toleranc } \\
\mathrm{e}\end{array}$ & VIF \\
\hline (Constant) & $-33,049$ & 1,418 & & $-23,310$ & 0,000 & & \\
\hline paros gdp szorzata & 0,838 & 0,028 & 0,836 & 30,254 & 0,000 & 0,615 & 1,626 \\
\hline paros gdp/fo szorzata & 0,187 & 0,051 & 0,105 & 3,709 & 0,000 & 0,590 & 1,696 \\
\hline ln tavolsag & $-0,867$ & 0,096 & $-0,197$ & $-9,026$ & 0,000 & 0,982 & 1,018 \\
\hline 2007-e? & $-0,054$ & 0,133 & $-0,011$ & $-0,405$ & 0,686 & 0,627 & 1,595 \\
\hline 2008-e? & $-0,187$ & 0,134 & $-0,038$ & $-1,398$ & 0,163 & 0,619 & 1,616 \\
\hline 2009-e? & $-0,634$ & 0,135 & $-0,131$ & $-4,695$ & 0,000 & 0,604 & 1,655 \\
\hline 2010-e? & $-0,340$ & 0,134 & $-0,070$ & $-2,529$ & 0,012 & 0,616 & 1,623 \\
\hline
\end{tabular}

Hibatag statisztikája

\begin{tabular}{lrrrrr}
\hline \hline & Minimum & Maximum & \multicolumn{1}{c}{ Átlag } & \multicolumn{1}{c}{ Szórás } & N \\
\hline Becsült érték & 3,4573 & 12,4015 & 7,7434 & 1,75478 & 399 \\
Hibatag & $-5,57012$ & 4,02657 & 0,00000 & 0,83208 & 399 \\
Std. becsült érték & $-2,443$ & 2,654 & 0,000 & 1,000 & 399 \\
Std. hibatag & $-6,635$ & 4,796 & 0,000 & 0,991 & 399 \\
\hline \hline
\end{tabular}




\section{TELJES AFT}

Modell összefoglalója

\begin{tabular}{llcrrr}
\hline \hline Modell & $\mathrm{R}$ & $\mathrm{R}^{2}$ & Adj. $\mathrm{R}^{2}$ & $\begin{array}{c}\text { Becslés standard } \\
\text { hibája }\end{array}$ & $\begin{array}{l}\text { Durbin- } \\
\text { Watson }\end{array}$ \\
\hline 1 & 0,906 & 0,822 & 0,818 & 0,82886 & 2,155 \\
\hline \hline
\end{tabular}

ANOVA

\begin{tabular}{llrrrrr}
\hline \hline & Modell & Négyzetösszeg & df & Négyzetes átlag & \multicolumn{1}{c}{ F } & \multicolumn{1}{c}{ Sig. } \\
\hline 1 & Regresszió & 1233,162 & 8 & 154,145 & 224,369 & 0,000 \\
& Hibatag & 267,936 & 390 & 0,687 & & \\
& Total & 1501,099 & 398 & & & \\
\hline \hline
\end{tabular}

Regressziós együtthatók

\begin{tabular}{|c|c|c|c|c|c|c|c|}
\hline \multirow[t]{2}{*}{ Modell } & \multicolumn{2}{|c|}{$\begin{array}{c}\text { Nem standardizált } \\
\text { együttható }\end{array}$} & \multirow{2}{*}{$\begin{array}{c}\begin{array}{c}\text { Standardizál } \\
\text { t együttható }\end{array} \\
\text { Beta } \\
\end{array}$} & \multirow[b]{2}{*}{$\mathrm{t}$} & \multirow[b]{2}{*}{ Sig. } & \multicolumn{2}{|c|}{ Kollinearitás } \\
\hline & $\mathrm{B}$ & Std. hiba & & & & $\begin{array}{c}\text { Toleranc } \\
\mathrm{e}\end{array}$ & VIF \\
\hline (Constant) & $-32,467$ & 1,411 & & $-23,014$ & 0,000 & & \\
\hline paros gdp szorzata & 0,774 & 0,034 & 0,772 & 23,084 & 0,000 & 0,410 & 2,441 \\
\hline paros gdp/fo szorzata & 0,266 & 0,055 & 0,149 & 4,823 & 0,000 & 0,481 & 2,080 \\
\hline ln tavolsag & $-0,808$ & 0,096 & $-0,184$ & $-8,374$ & 0,000 & 0,949 & 1,054 \\
\hline 2007-e? & $-0,038$ & 0,131 & $-0,008$ & $-0,290$ & 0,772 & 0,626 & 1,597 \\
\hline 2008-e? & $-0,220$ & 0,133 & $-0,045$ & $-1,655$ & 0,099 & 0,616 & 1,624 \\
\hline 2009-e? & $-0,683$ & 0,134 & $-0,141$ & $-5,091$ & 0,000 & 0,597 & 1,675 \\
\hline 2010-e? & $-0,387$ & 0,133 & $-0,080$ & $-2,901$ & 0,004 & 0,609 & 1,641 \\
\hline Teljes AFT, ln & 0,104 & 0,031 & 0,090 & 3,331 & 0,001 & 0,630 & 1,586 \\
\hline
\end{tabular}

Hibatag statisztikája

\begin{tabular}{lrrrrr}
\hline \hline & Minimum & Maximum & \multicolumn{1}{c}{ Átlag } & \multicolumn{1}{c}{ Szórás } & N \\
\hline Becsült érték & 3,4234 & 12,4432 & 7,7434 & 1,76023 & 399 \\
Hibatag & $-5,51089$ & 3,67826 & 0,00000 & 0,82049 & 399 \\
Std. becsült érték & $-2,454$ & 2,670 & 0,000 & 1,000 & 399 \\
Std. hibatag & $-6,649$ & 4,438 & 0,000 & 0,990 & 399 \\
\hline \hline
\end{tabular}




\section{TELJES AFT + ACP, LDC, OIL DUMMY}

Modell összefoglalója

\begin{tabular}{llcrrr}
\hline \hline Modell & $\mathrm{R}$ & $\mathrm{R}^{2}$ & Adj. $\mathrm{R}^{2}$ & $\begin{array}{c}\text { Becslés standard } \\
\text { hibája }\end{array}$ & $\begin{array}{l}\text { Durbin- } \\
\text { Watson }\end{array}$ \\
\hline 1 & 0,917 & 0,841 & 0,836 & 0,78559 & 2,115 \\
\hline \hline
\end{tabular}

ANOVA

\begin{tabular}{llrrrrr}
\hline \hline & Modell & Négyzetösszeg & df & Négyzetes átlag & \multicolumn{1}{c}{ F } & Sig. \\
\hline 1 & Regresszió & 1262,261 & 11 & 114,751 & 185,937 & 0,000 \\
& Hibatag & 238,838 & 387 &, 617 & & \\
Total & 1501,099 & 398 & & & \\
& & & & & & \\
\hline \hline
\end{tabular}

Regressziós együtthatók

\begin{tabular}{|c|c|c|c|c|c|c|c|}
\hline \multirow[t]{2}{*}{ Modell } & \multicolumn{2}{|c|}{$\begin{array}{c}\text { Nem standardizált } \\
\text { együttható }\end{array}$} & \multirow{2}{*}{$\begin{array}{c}\begin{array}{c}\text { Standardizál } \\
\text { t együttható }\end{array} \\
\text { Beta }\end{array}$} & \multirow[b]{2}{*}{$\mathrm{t}$} & \multirow[b]{2}{*}{ Sig. } & \multicolumn{2}{|c|}{ Kollinearitás } \\
\hline & B & Std. hiba & & & & $\begin{array}{c}\text { Toleranc } \\
\mathrm{e}\end{array}$ & VIF \\
\hline (Constant) & $-33,228$ & 1,805 & & $-18,413$ & 0,000 & & \\
\hline paros gdp szorzata & 0,794 & 0,034 & 0,792 & 23,672 & 0,000 & 0,368 & 2,721 \\
\hline paros gdp/fo szorzata & 0,231 & 0,065 & 0,129 & 3,542 & 0,000 & 0,310 & 3,225 \\
\hline ln tavolsag & $-0,803$ & 0,092 & $-0,183$ & $-8,699$ & 0,000 & 0,931 & 1,074 \\
\hline 2007-e? & $-0,034$ & 0,124 & $-0,007$ & $-0,270$ & 0,787 & 0,624 & 1,604 \\
\hline 2008-e? & $-0,224$ & 0,128 & $-0,046$ & $-1,751$ & 0,081 & 0,595 & 1,679 \\
\hline 2009-e? & $-0,684$ & 0,131 & $-0,141$ & $-5,233$ & 0,000 & 0,564 & 1,773 \\
\hline 2010-e? & $-0,382$ & 0,129 & $-0,078$ & $-2,961$ & 0,003 & 0,585 & 1,709 \\
\hline Teljes AFT, ln & 0,115 & 0,030 & 0,099 & 3,851 & 0,000 & 0,617 & 1,622 \\
\hline ACP-ország-e & 0,601 & 0,100 & 0,155 & 6,028 & 0,000 & 0,622 & 1,607 \\
\hline olajexportor orszag & 0,132 & 0,113 & 0,026 & 1,169 & 0,243 & 0,853 & 1,172 \\
\hline LDC & $-0,443$ & 0,127 & $-0,112$ & $-3,489$ & 0,001 & 0,395 & 2,529 \\
\hline
\end{tabular}

Hibatag statisztikája

\begin{tabular}{lrrrrr}
\hline \hline & Minimum & Maximum & \multicolumn{1}{c}{ Átlag } & \multicolumn{1}{c}{ Szórás } & N \\
\hline Becsült érték & 3,6408 & 12,4212 & 7,7434 & 1,78087 & 399 \\
Hibatag & $-5,51321$ & 3,82355 & 0,00000 & 0,77466 & 399 \\
Std. becsült érték & $-2,304$ & 2,627 & 0,000 & 1,000 & 399 \\
Std. hibatag & $-7,018$ & 4,867 & 0,000 & 0,986 & 399 \\
\hline \hline
\end{tabular}




\section{AFT*ACP INTERAKCIÓ}

Modell összefoglalója

\begin{tabular}{llcrrr}
\hline \hline Modell & $\mathrm{R}$ & $\mathrm{R}^{2}$ & Adj. $\mathrm{R}^{2}$ & $\begin{array}{c}\text { Becslés standard } \\
\text { hibája }\end{array}$ & $\begin{array}{c}\text { Durbin- } \\
\text { Watson }\end{array}$ \\
\hline 1 & 0,917 & 0,840 & 0,836 & 0,78719 & 2,115 \\
\hline \hline
\end{tabular}

ANOVA

\begin{tabular}{llrrrrr}
\hline \hline & Modell & Négyzetösszeg & df & Négyzetes átlag & \multicolumn{1}{c}{ F } & Sig. \\
\hline 1 & Regresszió & 1261,287 & 11 & 114,662 & 185,038 & 0,000 \\
& Hibatag & 239,812 & 387 & 0,620 & & \\
& Total & 1501,099 & 398 & & & \\
& & & & & & \\
\end{tabular}

Regressziós együtthatók

\begin{tabular}{|c|c|c|c|c|c|c|c|}
\hline \multirow[t]{2}{*}{ Modell } & \multicolumn{2}{|c|}{$\begin{array}{c}\text { Nem standardizált } \\
\text { együttható }\end{array}$} & \multirow{2}{*}{$\begin{array}{c}\begin{array}{c}\text { Standardizál } \\
\text { t együttható }\end{array} \\
\text { Beta }\end{array}$} & \multirow[b]{2}{*}{$\mathrm{t}$} & \multirow[b]{2}{*}{ Sig. } & \multicolumn{2}{|c|}{ Kollinearitás } \\
\hline & $\mathrm{B}$ & Std. hiba & & & & $\begin{array}{c}\text { Toleranc } \\
\mathrm{e}\end{array}$ & VIF \\
\hline (Constant) & $-32,779$ & 1,710 & & $-19,173$ & 0,000 & & \\
\hline paros gdp szorzata & 0,796 & 0,034 & 0,793 & 23,698 & 0,000 & 0,368 & 2,714 \\
\hline paros gdp/fo szorzata & 0,212 & 0,064 & 0,118 & 3,314 & 0,001 & 0,324 & 3,085 \\
\hline ln tavolsag & $-0,803$ & 0,092 & $-0,183$ & $-8,713$ & 0,000 & 0,939 & 1,065 \\
\hline 2007-e? & $-0,029$ & 0,125 & $-0,006$ & $-0,234$ & 0,815 & 0,623 & 1,604 \\
\hline 2008-e? & $-0,210$ & 0,128 & $-0,043$ & $-1,645$ & 0,101 & 0,598 & 1,674 \\
\hline 2009-e? & $-0,665$ & 0,131 & $-0,137$ & $-5,085$ & 0,000 & 0,567 & 1,763 \\
\hline 2010-e? & $-0,374$ & 0,129 & $-0,077$ & $-2,899$ & 0,004 & 0,588 & 1,702 \\
\hline Teljes AFT, ln & 0,098 & 0,030 & 0,084 & 3,283 & 0,001 & 0,624 & 1,603 \\
\hline $\mathrm{AfT}^{*} \mathrm{ACP}$ & 0,058 & 0,010 & 0,146 & 5,820 & 0,000 & 0,660 & 1,515 \\
\hline AFT*LDC & $-0,047$ & 0,013 & $-0,119$ & $-3,781$ & 0,000 & 0,415 & 2,410 \\
\hline AFT*olaj & 0,012 & 0,011 & 0,024 & 1,070 & 0,285 & 0,836 & 1,196 \\
\hline
\end{tabular}

Hibatag statisztikája

\begin{tabular}{lrrrrr}
\hline \hline & Minimum & Maximum & \multicolumn{1}{c}{ Átlag } & \multicolumn{1}{c}{ Szórás } & $\mathrm{N}$ \\
\hline Becsült érték & 3,5614 & 12,3868 & 7,7434 & 1,78019 & 399 \\
Hibatag & $-5,50872$ & 3,84413 & 0,00000 & 0,77624 & 399 \\
Std. becsült érték & $-2,349$ & 2,608 & 0,000 & 1,000 & 399 \\
Std. hibatag & $-6,998$ & 4,883 & 0,000 & 0,986 & 399 \\
\hline \hline
\end{tabular}




\section{AFT RÉSZTERÜLETEI}

Modell összefoglalója

\begin{tabular}{lcrrrr}
\hline \hline Modell & $\mathrm{R}$ & $\mathrm{R}^{2}$ & Adj. $\mathrm{R}^{2}$ & $\begin{array}{c}\text { Becslés standard } \\
\text { hibája }\end{array}$ & $\begin{array}{l}\text { Durbin- } \\
\text { Watson }\end{array}$ \\
\hline 1 & 0,907 & 0,823 & 0,818 & 0,82768 & 2,171 \\
\hline \hline
\end{tabular}

ANOVA

\begin{tabular}{llrrrrr}
\hline \hline & Modell & Négyzetösszeg & df & Négyzetes átlag & F & \multicolumn{1}{c}{ Sig. } \\
\hline 1 & Regresszió & 1235,297 & 10 & 123,530 & 180,320 & 0,000 \\
& Hibatag & 265,802 & 388 & 0,685 & & \\
& Total & 1501,099 & 398 & & & \\
\hline \hline
\end{tabular}

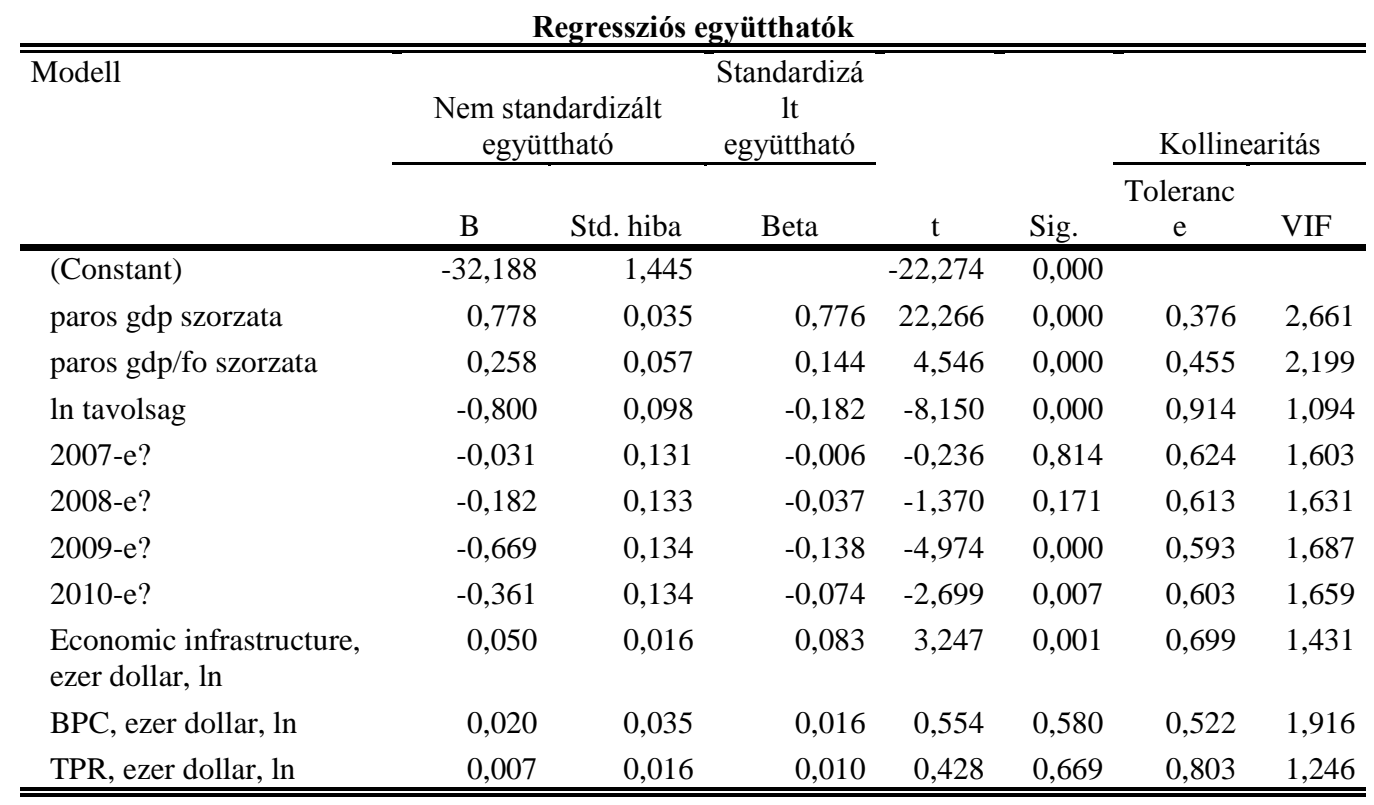

Hibatag statisztikája

\begin{tabular}{lrrrrr}
\hline \hline & Minimum & Maximum & \multicolumn{1}{c}{ Átlag } & \multicolumn{1}{c}{ Szórás } & \multicolumn{1}{c}{$\mathrm{N}$} \\
\hline Becsült érték & 3,3422 & 12,4860 & 7,7434 & 1,76175 & 399 \\
Hibatag & $-5,44918$ & 3,66819 & 0,00000 & 0,81722 & 399 \\
Std. becsült érték & $-2,498$ & 2,692 & 0,000 & 1,000 & 399 \\
Std. hibatag & $-6,584$ & 4,432 & 0,000 & 0,987 & 399 \\
\hline \hline
\end{tabular}




\section{AFT RÉSZTERÜLETEI + ACP, LDC, OIL DUMMY}

Modell összefoglalója

\begin{tabular}{lllrrr}
\hline \hline Modell & $\mathrm{R}$ & $\mathrm{R}^{2}$ & Adj. $\mathrm{R}^{2}$ & $\begin{array}{c}\text { Becslés standard } \\
\text { hibája }\end{array}$ & $\begin{array}{c}\text { Durbin- } \\
\text { Watson }\end{array}$ \\
\hline 1 & 0,919 & 0,844 & 0,838 & 0,78061 & 2,138 \\
\hline \hline
\end{tabular}

ANOVA

\begin{tabular}{llrrrrr}
\hline \hline & Modell & Négyzetösszeg & df & Négyzetes átlag & F & Sig. \\
\hline 1 & Regresszió & 1266,497 & 13 & 97,423 & 159,879 & 0,000 \\
& Hibatag & 234,602 & 385 & 0,609 & & \\
& Total & 1501,099 & 398 & & & \\
\hline \hline
\end{tabular}

Regressziós együtthatók

\begin{tabular}{|c|c|c|c|c|c|c|c|}
\hline \multirow[t]{2}{*}{ Modell } & $\begin{array}{r}\text { Nem stan } \\
\text { együt } \\
\end{array}$ & $\begin{array}{l}\text { lardizált } \\
\text { ható }\end{array}$ & $\begin{array}{c}\text { Standardizá } \\
\text { lt } \\
\text { együttható } \\
\end{array}$ & & & \multicolumn{2}{|c|}{ Kollinearitás } \\
\hline & $\mathrm{B}$ & Std. hiba & Beta & $\mathrm{t}$ & Sig. & $\begin{array}{c}\text { Toleranc } \\
\mathrm{e}\end{array}$ & VIF \\
\hline (Constant) & $-32,683$ & 1,817 & & $-17,992$ & 0,000 & & \\
\hline paros gdp szorzata & 0,804 & 0,035 & 0,801 & 23,116 & 0,000 & 0,338 & 2,960 \\
\hline paros gdp/fo szorzata & 0,195 & 0,066 & 0,109 & 2,940 & 0,003 & 0,296 & 3,377 \\
\hline ln tavolsag & $-0,783$ & 0,093 & $-0,178$ & $-8,396$ & 0,000 & 0,900 & 1,111 \\
\hline 2007-e? & $-0,026$ & 0,124 & $-0,005$ & $-0,208$ & 0,835 & 0,621 & 1,610 \\
\hline 2008-e? & $-0,166$ & 0,127 & $-0,034$ & $-1,301$ & 0,194 & 0,592 & 1,688 \\
\hline 2009-e? & $-0,654$ & 0,131 & $-0,135$ & $-5,008$ & 0,000 & 0,558 & 1,791 \\
\hline 2010-e? & $-0,337$ & 0,129 & $-0,069$ & $-2,609$ & 0,009 & 0,577 & 1,734 \\
\hline $\begin{array}{l}\text { Economic infrastructure, } \\
\text { ezer dollar, } \ln \end{array}$ & 0,065 & 0,015 & 0,106 & 4,372 & 0,000 & 0,686 & 1,458 \\
\hline BPC, ezer dollar, ln & 0,004 & 0,034 & 0,003 & 0,115 & 0,909 & 0,506 & 1,975 \\
\hline TPR, ezer dollar, ln & 0,002 & 0,015 & 0,003 & 0,142 & 0,887 & 0,797 & 1,255 \\
\hline ACP-ország-e & 0,614 & 0,100 & 0,158 & 6,168 & 0,000 & 0,617 & 1,621 \\
\hline olajexportor orszag & 0,113 & 0,112 & 0,022 & 1,009 & 0,314 & 0,853 & 1,173 \\
\hline LDC & $-0,509$ & 0,128 & $-0,129$ & $-3,989$ & 0,000 & 0,387 & 2,586 \\
\hline
\end{tabular}

Hibatag statisztikája

\begin{tabular}{lrrrrr}
\hline \hline & Minimum & Maximum & \multicolumn{1}{c}{ Átlag } & \multicolumn{1}{c}{ Szórás } & N \\
\hline Becsült érték & 3,6516 & 12,4583 & 7,7434 & 1,78386 & 399 \\
Hibatag & $-5,39874$ & 3,73813 & 0,00000 & 0,76776 & 399 \\
Std. becsült érték & $-2,294$ & 2,643 & 0,000 & 1,000 & 399 \\
Std. hibatag & $-6,916$ & 4,789 & 0,000 & 0,984 & 399 \\
\hline \hline
\end{tabular}




\section{NEM ACP-ORSZÁGOK}

Modell összefoglalója

\begin{tabular}{lccccc}
\hline \hline Modell & $\mathrm{R}$ & $\mathrm{R}^{2}$ & Adj. $\mathrm{R}^{2}$ & $\begin{array}{c}\text { Becslés standard } \\
\text { hibája }\end{array}$ & $\begin{array}{c}\text { Durbin- } \\
\text { Watson }\end{array}$ \\
\hline 1 & 0,919 & 0,845 & 0,837 & 0,79701 & 2,140 \\
\hline \hline
\end{tabular}

ANOVA

\begin{tabular}{llrrrrr}
\hline \hline & Modell & Négyzetösszeg & df & Négyzetes átlag & F & Sig. \\
\hline 1 & Regresszió & 667,279 & 10 & 66,728 & 105,047 & 0,000 \\
& Hibatag & 121,962 & 192 & 0,635 & & \\
& Total & 789,240 & 202 & & & \\
\hline \hline
\end{tabular}

\section{Regressziós együtthatók}

\begin{tabular}{|c|c|c|c|c|c|c|c|}
\hline \multirow[t]{2}{*}{ Modell } & \multicolumn{2}{|c|}{$\begin{array}{c}\text { Nem standardizált } \\
\text { együttható }\end{array}$} & \multirow{2}{*}{$\begin{array}{c}\begin{array}{c}\text { Standardizál } \\
\text { t együttható }\end{array} \\
\text { Beta } \\
\end{array}$} & \multirow[b]{2}{*}{$\mathrm{t}$} & \multirow[b]{2}{*}{ Sig. } & \multicolumn{2}{|c|}{ Kollinearitás } \\
\hline & B & Std. hiba & & & & $\begin{array}{c}\text { Toleranc } \\
\mathrm{e}\end{array}$ & VIF \\
\hline (Constant) & $-39,287$ & 2,009 & & $-19,552$ & 0,000 & & \\
\hline paros gdp szorzata & 0,889 & 0,048 & 0,789 & 18,632 & 0,000 & 0,448 & 2,230 \\
\hline paros gdp/fo szorzata & 0,291 & 0,091 & 0,137 & 3,190 & 0,002 & 0,437 & 2,290 \\
\hline ln tavolsag & $-0,791$ & 0,107 & $-0,226$ & $-7,419$ & 0,000 & 0,867 & 1,154 \\
\hline 2007-e? & $-0,081$ & 0,178 & $-0,017$ & $-0,459$ & 0,647 & 0,616 & 1,624 \\
\hline 2008-e? & $-0,277$ & 0,183 & $-0,055$ & $-1,517$ & 0,131 & 0,605 & 1,653 \\
\hline 2009-e? & $-0,828$ & 0,186 & $-0,169$ & $-4,440$ & 0,000 & 0,559 & 1,790 \\
\hline 2010-e? & $-0,604$ & 0,184 & $-0,123$ & $-3,286$ & 0,001 & 0,574 & 1,741 \\
\hline $\begin{array}{l}\text { Economic infrastructure, } \\
\text { ezer dollar, } \ln \end{array}$ & 0,077 & 0,026 & 0,113 & 2,956 & 0,004 & 0,553 & 1,809 \\
\hline BPC, ezer dollar, ln & 0,037 & 0,047 & 0,030 & 0,796 & 0,427 & 0,575 & 1,738 \\
\hline TPR, ezer dollar, ln & $-0,032$ & 0,022 & $-0,047$ & $-1,491$ & 0,138 & 0,793 & 1,261 \\
\hline
\end{tabular}

Hibatag statisztikája

\begin{tabular}{lrrrrr}
\hline \hline & Minimum & Maximum & \multicolumn{1}{c}{ Átlag } & \multicolumn{1}{c}{ Szórás } & \multicolumn{1}{c}{ N } \\
\hline Becsült érték & 4,7126 & 12,6285 & 8,5368 & 1,81751 & 203 \\
Hibatag & $-5,19903$ & 3,64739 & 0,00000 & 0,77703 & 203 \\
Std. becsült érték & $-2,104$ & 2,251 & 0,000 & 1,000 & 203 \\
Std. hibatag & $-6,523$ & 4,576 & 0,000 & 0,975 & 203 \\
\hline \hline
\end{tabular}




\section{ACP-ORSZÁGOK}

Modell illeszkedése

\begin{tabular}{ccccc}
\hline \hline Modell & $\mathrm{R}$ & $\mathrm{R}^{2}$ & Adj. $\mathrm{R}^{2}$ & $\begin{array}{c}\text { Becslés } \\
\text { standard } \\
\text { hibája }\end{array}$ \\
\hline 0,867 & 0,751 & 0,736 & 0,763 & 1,990 \\
\hline \hline \multicolumn{4}{c}{ Cochrane-Orcutt becsléssel. }
\end{tabular}

Cochrane-Orcutt becsléssel.

\begin{tabular}{llrr}
\multicolumn{4}{c}{ ANOVA } \\
\hline \hline Modell & $\begin{array}{c}\text { Négyzetö } \\
\text { sszeg }\end{array}$ & df & $\begin{array}{c}\text { Négyzetes } \\
\text { átlag }\end{array}$ \\
\hline Regresszió & 321,685 & 10 & 32,168 \\
\hline Hibatag & 106,414 & 183 & 0,581 \\
\hline \hline
\end{tabular}

Cochrane-Orcutt becsléssel.

Regressziós együtthatók

\begin{tabular}{lcccrc}
\hline \hline Modell & \multicolumn{2}{c}{$\begin{array}{c}\text { Nem standardizált } \\
\text { együttható }\end{array}$} & $\begin{array}{c}\text { Standardizált } \\
\text { együttható }\end{array}$ & \multicolumn{1}{c}{ t } & Sig. \\
\cline { 2 - 6 } & \multicolumn{1}{c}{ B } & Std. hiba & Beta & & \\
\hline paros gdp szorzata & 0,666 & 0,053 & 0,667 & 12,579 & 0,000 \\
paros gdp/fo szorzata & 0,437 & 0,077 & 0,287 & 5,700 & 0,000 \\
ln tavolsag & $-0,605$ & 0,230 & $-0,105$ & $-2,631$ & 0,009 \\
2007-e? & $-0,026$ & 0,142 & $-0,009$ & $-0,181$ & 0,857 \\
2008-e? & $-0,228$ & 0,143 & $-0,077$ & $-1,590$ & 0,114 \\
2009-e? & $-0,673$ & 0,148 & $-0,224$ & $-4,541$ & 0,000 \\
2010-e? & $-0,239$ & 0,146 & $-0,079$ & $-1,635$ & 0,104 \\
Economic infrastructure, & 0,039 & 0,018 & 0,088 & 2,122 & 0,035 \\
ezer dollar, ln & 0,057 & 0,050 & 0,059 & 1,134 & 0,258 \\
BPC, ezer dollar, ln & 0,025 & 0,020 & 0,053 & 1,245 & 0,215 \\
TPR, ezer dollar, ln & $-31,147$ & 2,831 & & $-11,000$ & 0,000 \\
(Constant) & Cochrant
\end{tabular}

Cochrane-Orcutt becsléssel. 